
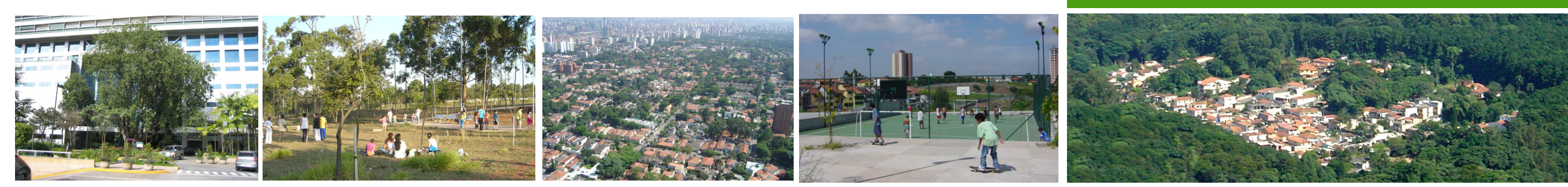

COMPENSAÇÃO AMBIENTAL

uma alternativa para viabilização de espaços livres

públicos para lazer e convívio na cidade de São Paulo 



\section{COMPENSAÇÃO AMBIENTAL}

Uma alternativa para viabilização de espaços livres públicos para convívio e lazer na cidade de São Paulo

Dissertação apresentada à Faculdade de Arquitetura e Urbanismo da Universidade de São Paulo para obtenção do título de mestre

Orientador

Prof. Silvio Soares Macedo

Área de Concentração

Paisagem e Ambiente 
AUTORIZO A REPRODUÇ̃̃O E DIVULGAÇ̃̃O TOTAL OU PARCIAL DESTE TRABALHO, POR QUALQUER MEIO CONVENCIONAL OU ELETRÔNICO, PARA FINS DE ESTUDO E PESQUISA, DESDE QUE CITADA A FONTE.

E-MAIL: Iloyolla@gmail.com

Coelho, Leonardo Loyolla

6672c Compensação ambiental: uma alternativa para a

viabilização de espaços livres públicos para convívio e lazer

na cidade de São Paulo / Leonardo Loyolla Coelho. -- São

Paulo, 2008.

209 p. : il.

Dissertação (Mestrado - Área de Concentração: Paisagem e ambiente) - FAUUSP.

Orientador: Silvio Soares Macedo

1.Espaços livres - São Paulo(SP) 2.Legislação ambiental 3.Arborização 4.Espaço público I.Título

CDU $712.25(816.11)$ 
Aos meus pais, por todo o carinho, incentivo e confiança dados ao longo de toda a trajetória que permitiu que eu chegasse até aqui. 

Aos meus pais e minha irmã por todo o apoio dado para a revisão e tradução deste trabalho.

Ao Prof. Silvio Soares Macedo, pelo apoio e atenção nos momentos cruciais da minha jornada acadêmica.

Ao Eng. Agr. Carlos Alberto da Silva Filho, pelo empenho, amizade e solicitude, que foram essenciais para a estruturação deste trabalho.

Aos Arquitetos Raul Pereira, Caio Boucinhas e toda equipe (Arqta. Daniela Ramalho, Arq. Chan Hua Xin, Arq. Rulian Nociti e Edemilson Anjos) pela amizade, apoio e confiança.

Às Professoras Catharina Cordeiro Lima, Miranda Magnoli, e ao Professor Eugenio Fernandes Queiroga, pelos valiosos "palpites", que muito auxiliaram no amadurecimento deste trabalho.

À equipe do Projeto Quapá, pelo apoio de sempre.

Ao Chefe de Gabinete da SVMA, Sr. Hélio Neves, pela presteza no fornecimento de informações muito importantes para o fechamento do trabalho.

À equipe DEPAVE, em especial à Arquiteta Célia Seri Kawai, que forneceu com muita solicitude informações preciosas para este trabalho.

À equipe da Câmara de Compensação Ambiental, em especial ao Eng. Belmiro Andrade, Evelyne e Tatiana pela presteza e alto astral com o qual sempre me atenderam.

Aos Eng. Agr. José Manoel Gobbi, Marcelo Cocco Urtado, Jorge Sakai e Walter Doering, à Geogr. Ana Beatriz e à Arquiteta Maria Cristina Antunes pelas contribuições dadas a este trabalho.

À CAPES, por todo respaldo prestado ao longo deste curso. 

Este trabalho tem por objetivo analisar como a compensação ambiental contribui para atenuar o déficit de espaços livres públicos na cidade de São

Paulo. Para tal, contextualiza o mecanismo em relação a outros existentes no país e traça a evolução histórica da legislação compensatória desde o início de sua aplicação no município, em 1998. Abordam-se também os diferentes papéis desempenhados pela arborização urbana e pelos espaços livres públicos como formas de compensação aos danos causados ao meio ambiente. Por fim, é realizado o mapeamento das ações compensatórias que resultaram na produção de espaços livres públicos e uma análise dos aspectos deficitários e positivos do mecanismo, visando seu aperfeiçoamento

\section{RESUMO}

This academic essay focuses in the analysis of how the environmental compensation contributes to the attenuation of public open spaces deficit in the city of São Paulo. To achieve this goal, it is made a contextualization of this mechanism respecting the other ones in Brazil and an outlining of the historical evolution of the compensatory legislation from the beginning of its application in the city in 1998. It also broaches

the different roles performed by the urban forestry and the public open spaces as compensations for the environmental damage. This essay also makes a mapping of the actions that resulted in the production of public open spaces and the evaluation of the positive aspects of the mechanism and the ones to be improved, aiming its betterment. 

Cap. I Introdução

Déficit e redução do estoque de espaços livres públicos na cidade de São Paulo ……..................................................................... 13

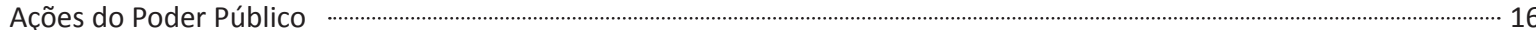

Ações da iniciativa privada e interações com o Poder Público …..............................................................................................................2 22

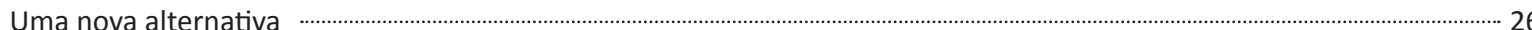

Cap. II Compensações ambientais: uma abordagem conceitual

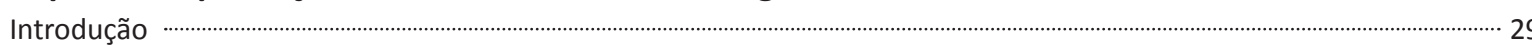

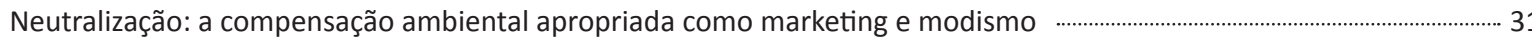

Valoração ambiental: o enfoque econômico das compensações ……….......................................................................................................... 34

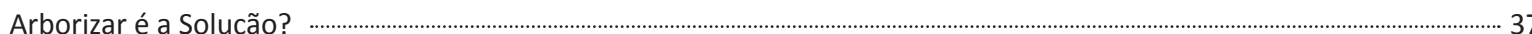

\section{Cap. III Compensações Ambientais em São Paulo}

Preparando o terreno: a inserção das compensações ambientais na legislação brasileira e paulista ……………………………... 49

O Departamento de Parques e Áreas Verdes de São Paulo (DEPAVE) ………………………....................................................................................5 53

Evolução (e algumas involuções) da compensação ambiental na cidade de São Paulo ……………............................................................ 57

Onze anos iniciais: da reposição à compensação ……………...................................................................................................................... 57

Gestão Marta Suplicy: a consolidação das compensações ambientais no município ....................................................................... 66

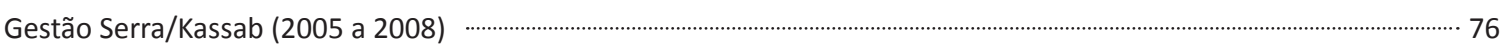

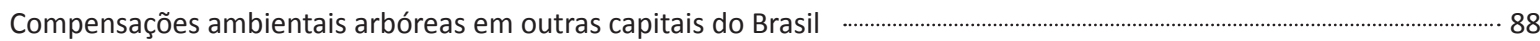

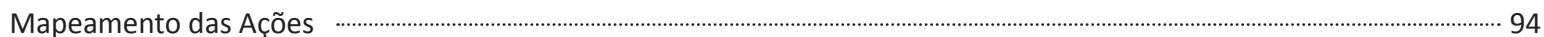

Estudos de caso - Espaços livres públicos gerados por compensações ambientais na cidade de São Paulo ............................. 102

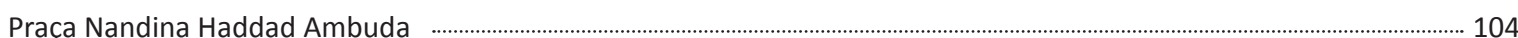

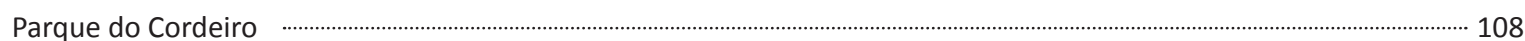

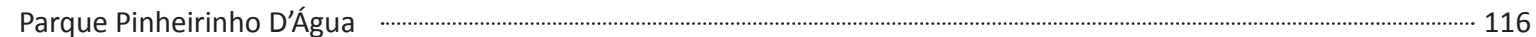

Parque Jacintho Alberto ............................................................................................................................................................................................................... 126

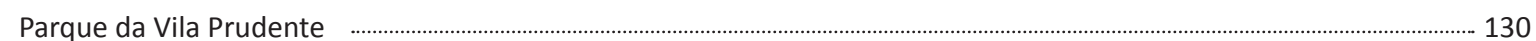

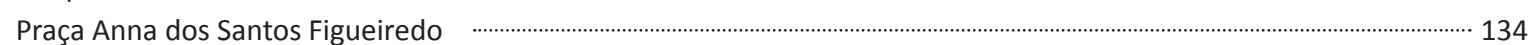

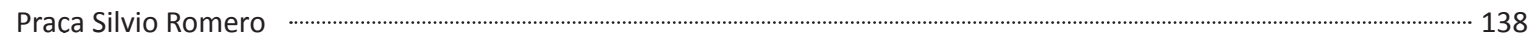

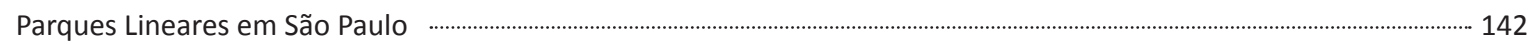

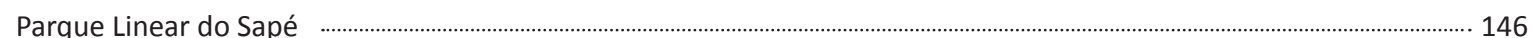

Hospital Alemão Oswaldo Cruz $\quad$........................................................................................................................................................................... 150

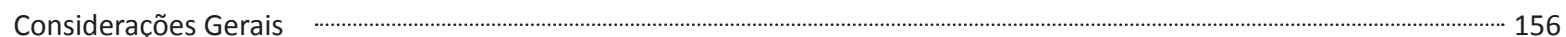

\section{Cap. IV Avanços e Retrocessos}

O que falta aperfeiçoar..

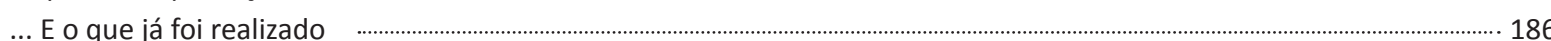

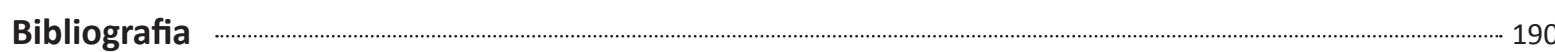

Apêndice (Funcionamento das Compensações Ambientais no Município de São Paulo) ............................................................. 202

Anexo (Memorando DEPAVE 41/1998) 

CAPÍTULO I

Introdução 



\section{Déficit e redução do estoque de espaços livres públicos na cidade de São Paulo}

O déficit de espaços livres públicos voltados ao lazer, ao convívio e à conservação de recursos naturais constitui um fato em diversas metrópoles do mundo, sendo uma constante no Município de São Paulo.

O processo de urbanização intenso, contínuo e bastante irregular não teve como prioridade a criação e a reserva de espaços livres para finalidades recreativas. Áreas antes utilizadas informalmente para recreação - tais como campos de futebol de várzea e as próprias ruas cederam lugar a adensadas massas edificadas, com pouco ou nenhum espaço para atividades de lazer. Ao mesmo tempo, o alto valor da terra urbana levou à redução gradativa do tamanho dos lotes e, conseqüentemente, restringiu as dimensões das áreas ajardinadas e quintais privados - que também eram utilizados para fins recreativos.

Como resultado desse processo, tem-se uma quantidade insuficiente de espaços livres para recreação e convívio, se relacionados ao tamanho da população que a cidade de São Paulo adquiriu durante o século $\mathrm{XX}^{1}$.

Embora exista uma demanda efetiva, a construção de novos espaços livres nunca constituiu prioridade para o Poder Público, tanto estadual quanto municipal.

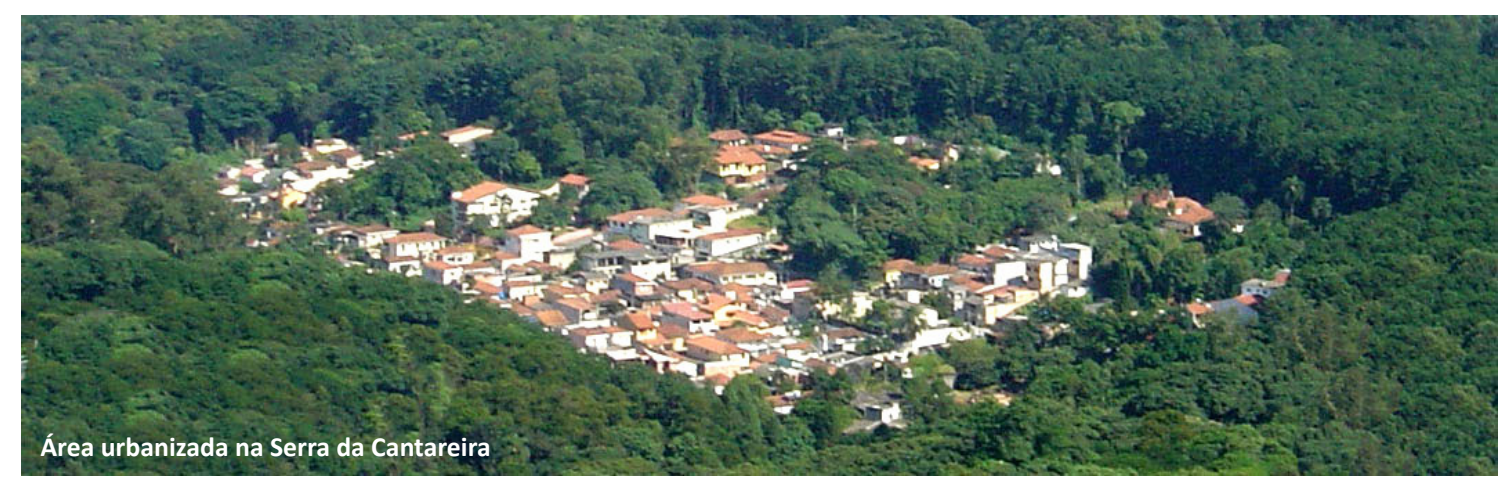

1.No intervalo entre os anos de 1940 e 1970 - períodos nos quais São Paulo apresentou suas maiores taxas de crescimento anual - a população da cidade aumentou mais de $450 \%$, passando de 1.326.261 para 5.924.615 habitantes. Fonte: IBGE/SEADE 
2.A participação da Secretaria do Verde e do Meio Ambiente no orçamento municipal aprovado entre os anos de $2000 \mathrm{e}$ 2004 não superou o reduzido patamar de $0,73 \%$ do total (esse valor ocorreu no ano de 2003). Nesse mesmo ano, os gastos com pavimentação de vias públicas correspondiam a 1,02\% do orçamento total do município. SÃO PAULO (cidade). Secretaria do Verde e do Meio Ambiente. IPT. GEO cidade de São Paulo: panorama do meio ambiente urbano. Brasília: PNUMA, 2004. p.27 e 147

3.o Plano Diretor Estratégico da cidade de São Paulo (Lei Municipal 13.430/2002), em seu art. 107, menciona a busca por "ampliar os espaços de lazer ativo e contemplativo, criando progressivamente parques lineares ao longo dos cursos d'água e fundos de vales não urbanizados".

4.Em 2002, de um total de 370 praças com mais de $6000 \mathrm{~m} 2$ na cidade de São Paulo, apenas "[...] os distritos Sé, Alto de Pinheiros, Vila Formosa e Morumbi dispõem, cada um deles, do maior número [. ] entre 15 e 24 . Grande parte dos distritos, num total de 46, possui apenas, no máximo, 5 praçs." são Paulo (Cidade) Secretaria do Verde e do Meio Ambiente. IPT GEO cidade de São Paulo: panorama do meio ambiente urbano.

5.A medida mais significativa nesse sentido, até o ano de 2008 foi o Plano de Areas Verdes para a cidade de São Paulo de 1967, coordenado pelas arquitetas paisagistas Miranda Martinelli Magnolli e Rosa Grena Kliass.

6. Ação realizada pela Empresa Municipal de Urbanização (EMURB) entre os anos de 2001 e 2004, responsável pela implantação de 49 praças, distribuídas pelas subprefeituras do Municipio de São Paulo. Cf. SAKATA, Francine Gramacho. $O$ projeto paisagistico como instrumento de requalificação urbana.
Os recursos direcionados para essa área são restritos, comparativamente a outros investimentos realizados no município ${ }^{2}$. Mesmo tendo um custo para implantação geralmente inferior ao de outros tipos de obras, a construção de praças e parques costuma ser preterida na pauta das administrações públicas, quando comparada a obras de maior visibilidade, como edificações ou melhoramentos viários.

Esse quadro começa lentamente a ser revertido de 2000 em diante, quando o Plano Diretor Estratégico do Município passa a refletir o aumento da preocupação com as questões ambientais ocorrido nos anos 1980 e 1990. Exemplo disso são as mobilizações da Secretaria do Verde e Meio Ambiente (SVMA) e Subprefeituras para criação de parques lineares $^{3}$ na cidade, intensificadas a partir do ano de 2007.

O descaso do Poder Público também pode ser observado com relação à inadequada distribuição dos espaços livres ${ }^{4}$. Muito poucas foram as iniciativas sistematizadas para implementação de áreas para lazer e convívio na cidade ${ }^{5}$ Q Quando existiram, as ações se voltaram tradicionalmente para o atendimento das áreas centrais e de elite, que possuem maior visibilidade e retorno político.

Prova disso é a inexistência (até o ano de 2008) de critérios legais que orientem a distribuição de espaços livres no município. Como resultado, as áreas mais carentes são aquelas que menos têm acesso aos espaços livres públicos para recreação e convívio. Somente a partir dos anos 2000, com o surgimento de alternativas como o Programa Centros de Bairro ${ }^{6}$, o investimento em espaços livres para bairros populares torna-se uma prática recorrente, embora ainda incipiente.

Sobrecarregados pela demanda reprimida, os espaços livres existentes sofrem ainda com a falta de manutenção e a gestão inadequada - apenas mais uma evidência do desinteresse do Poder Público com relação a esse assunto.

Paralelamente a todos esses problemas, as possibilidades reais de atuação do Poder Público no sentido de suprir a carência de espaços livres na cidade de São Paulo tornam-se cada vez mais restritas. Tal fato se deve à redução do estoque de áreas disponíveis para este fim. 
A despeito da redução de seu estoque, a cidade de São Paulo possui um conjunto considerável de espaços livres que, quantitativamente, poderiam suprir suas carências. Essa capacidade é restrita, no entanto, pela sua fragmentação, qualidade e real capacidade de utilização. Segundo o Atlas Ambiental do Município:

Estudos realizados no final da década de 1990, pela Secretaria Municipal de Planejamento SEMPLA [...] indicaram para a zona urbana um total de $31,3 \mathrm{~km}^{2}$ de áreas efetivamente doadas para áreas verdes. Cerca de 10,6 $\mathrm{km}^{2}$ eram efetivamente ocupados por praças, canteiros, etc. Do restante, $5 \mathrm{~km}^{2}$ encontram-se vazios e $15,7 \mathrm{~km}^{2}$ foram ocupados por outros usos, sendo $10 \mathrm{~km}^{2}$ por favelas. ${ }^{7}$

Embora o parcelamento gere sistematicamente novos espaços livres no município, a dimensão e a adequação destes para qualquer finalidade recreativa não é suficiente, mesmo que haja interesse para sua instalação. Como resultado, tem-se uma grande quantidade de espaços livres sem finalidades específicas, que acabam sendo utilizados ilegalmente para suprir outras demandas, tais como moradia.

Se os espaços livres de loteamentos regulares já apresentam problemas para destinação adequada, as formas de ocupação irregulares sequer os consideram. Com o avanço da urbanização informal rumo às franjas do município (principalmente em direção às represas Billings e Guarapiranga e à Serra da Cantareira), as áreas de proteção ambiental e os espaços livres remanescentes ficam cada vez mais suscetíveis às ocupações por usos irregulares, principalmente favelas. Segundo Menneh "66\% das favelas do município localizam-se em áreas públicas, em sua maioria doadas por meio de processos de parcelamento formal” ${ }^{8}$

Mesmo quando não ocupadas diretamente, áreas protegidas ambientalmente são ameaçadas pelos diversos problemas que a ação antrópica no entorno pode causar, tais como contaminação dos corpos d'água e o efeito de borda ${ }^{9}$.

O próprio Poder Público pode constituir uma ameaça à destinação adequada dos espaços livres, por meio da sua utilização para outras finalidades ${ }^{10}$. Esse processo consolidou-se a partir da década de 1940, quando o então prefeito Jânio Quadros cria um plano para

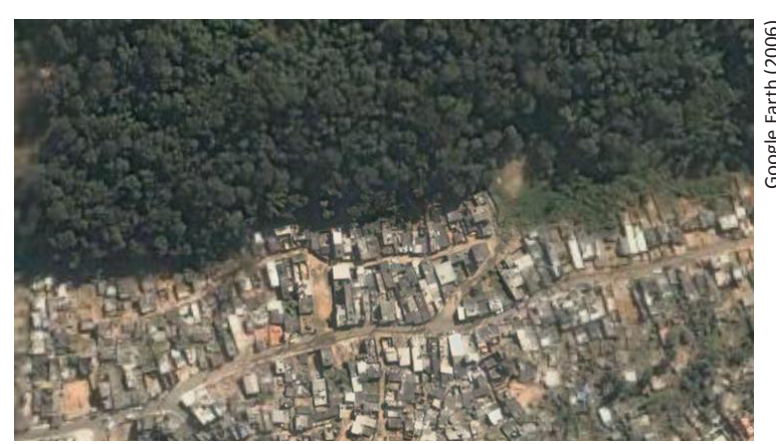

Loteamento irregular na Serra da Cantareira

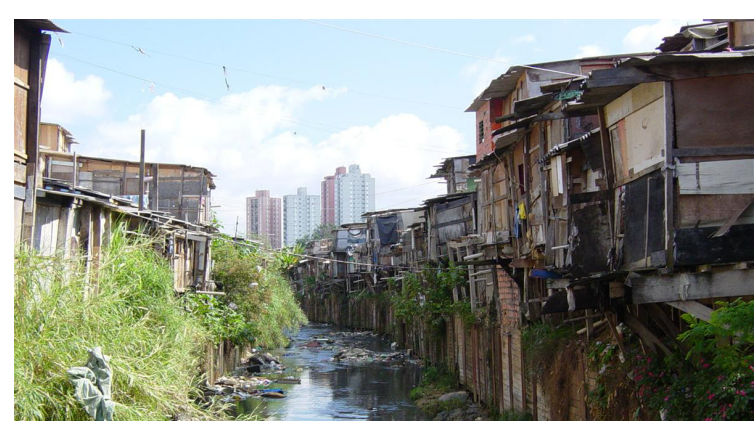

Favela próxima à Avenida Jornalista Roberto Marinho

7.SÃO PAULO (Cidade), Secretaria Municipal do Verde e Meio Ambiente. Atlas Ambiental Municipal do Município de São Paulo. São Paulo: SVMA, 2002. p.10

8.MENNEH, Márcia Unti Halluli. O sistema de espaços livres públicos da cidade de São Paulo. Tese de Doutorado. São Paulo: FAUUSP, 2002. p. 28

9. “O conceito de efeito de borda é definido como o aumento da variedade e densidade das populações de algumas espécies na zona do ecótono (interface entre duas comunidades ou ecossistemas), em comparação com o que ocorre na zona central do ecossistema ou comunidade a que elas pertence de borda no inventário dos maciços de eucalipto do Parque de borda no inventário dos maciços de eucalipto do Parque Ibirapuera por meio do uso de sensoriamento remoto Arborização Urbana. № 1 vol 2. Piracicaba, 2007.

10. “[...] o estoque de terrenos destinados à implantação de parques e praças se esgotou, como conseqüência de sua ocupação por favelas ou mesmo da sua utilização para outros fins, pelo próprio Poder Público". SÃO PAULO (Cidade), Secretaria Municipal do Verde e Meio Ambiente. Atlas Ambiental Municipal do Município de São Paulo. São Paulo: SVMA, 2002. p. 14 
11. Cf. DUARTE, Hélio de Queiroz. Escolas-classe, escola-parque: uma experiência educacional. São Paulo: FAUUSP, 1973

12. De acordo com o Diagnóstico Cartográfico Ambiental, de um total de $154 \mathrm{~km} 2$ de espaços livres existentes no município, apenas $42,3 \mathrm{~km} 2$ pertencem ao poder público. São Paulo (cidade). Secretaria Municipal do Verde e do Meio Ambiente. Diagnóstico Cartográfico Ambiental do Município de São Paulo. São Paulo, 1992.

13. "Atualmente, a Lei Municipal no 9413/81, que disciplina o parcelamento do solo no município, constitui-se, ainda que formalmente, a mais sistemática fonte de alimentação do estoque público de áreas livres, através da doação de áreas por ocasião do parcelamento de solo". SÃO PAULO (Cidade), Secretaria Municipal do Verde e Meio Ambiente. Atlas Ambiental Municipal do Município de São Paulo. São Paulo: SVMA, 2002. p.09

14. Por ser a terminologia usualmente empregada pela prefeitura de São Paulo, a expressão "área verde" terá, neste trabalho, significado equivalente a espaço livre. Ressalta-se, porém, que seus conceitos são distintos. conjugação do uso das escolas municipais paulistanas nos espaços livres disponíveis, as chamadas "escolas-parque"11. Desde então, torna-se prática corrente a ocupação de espaços livres por edifícios institucionais do próprio Poder Público.

Embora se devam considerar as dificuldades impostas pelo porte da cidade de São Paulo em face à necessidade de suprir a carência de espaços livres, variados são os instrumentos que podem colaborar para amenizar tal problema.

\section{Ações do Poder Público}

O Poder Público pode contribuir para amenizar o déficit de espaços livres disponíveis tanto por meio da criação de novas áreas para lazer e convívio, quanto pela manutenção e proteção adequada daqueles já existentes.

\section{Geração de novos espaços livres}

Considerando-se que apenas um terço dos espaços livres disponíveis no município de São Paulo pertence ao Poder Público ${ }^{12}$ e que os terrenos privados possuem relevo mais adequado, conclui-se que as maiores e melhores possibilidades de geração de novas áreas recreativas concentram-se em mãos da iniciativa privada. Esta, por sua vez, tem como principal objetivo convertê-los no máximo possível de áreas edificadas.

A desapropriação ou a aquisição direta de terrenos são alternativas relativamente dispendiosas e demoradas para transferir a tutela de espaços livres privados para o Poder Público. Por esse motivo, o parcelamento do solo tem sido o principal mecanismo utilizado no município para a captação de novos espaços livres públicos a partir de terrenos privados $^{13}$.

A Lei de Uso e Ocupação do Solo do município (Lei Municipal no 9413/1981) prevê a destinação de 15\% do total de um loteamento para destinação compulsória como Áreas Verdes ${ }^{14}$. Boa parte dessas áreas consideradas pelo Poder Público como "espaços livres" possuem condições inadequadas para serem destinadas à recreação e convívio. 
Gonçalves atribui os problemas na geração de espaços livres à suscetibilidade do parcelamento aos interesses dos agentes envolvidos no processo. $\mathrm{O}$ autor enumera alguns princípios lógicos que orientam o processo de destinação de áreas verdes em assentamentos urbanos $^{15}$.

Um deles é a escolha para áreas verdes de terrenos que possuem recursos naturais que restrinjam a capacidade construtiva do loteamento, tais como relevo acentuado e a presença de corpos d'água. Essas características de terreno mostram-se convenientes para a preservação de recursos hídricos e da vegetação das encostas dos morros, mas comprometem a possibilidade de uso recreativo das áreas geradas.

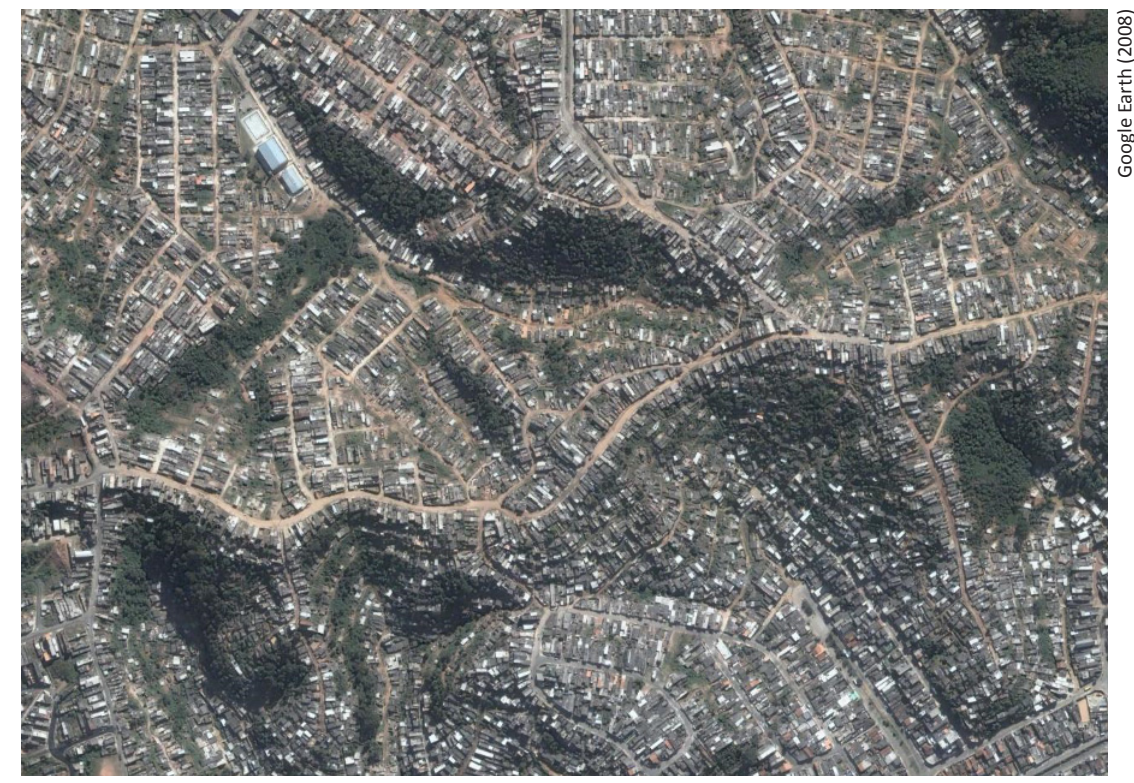

Área urbanizada no município

de Mauá (SP). Reserva de

espaços livres públicos

constituída basicamente por

terrenos de alta declividade $\mathrm{e}$

fundos de vale

Outro princípio lógico utilizado pelo loteador é a escolha para áreas verdes dos terrenos com menores áreas e formato mais irregular, que dificultariam a implantação de áreas edificadas. Tal característica das áreas geradas é igualmente inconveniente para fins recreativos, pois limita a tipologia dos espaços livres criados:
15. GONCALVES, Wantuelfer. Padrões de assentamento de áreas verdes municipais - uma visão crítica. Tese de Doutorado. São Paulo: FAUUSP, 1994. p.28 - 38 
Se a legislação de loteamento gerou poucos parques, até pela pulverização dos terrenos destinados às áreas verdes, ela originou, por outro lado, um número razoável de "praças" que foram equipadas e receberam tratamento paisagístico. ${ }^{16}$

Gonçalves também atribui a falta de priorização das áreas verdes ao próprio Poder Público: os espaços livres não estão sujeitos à mesma arrecadação de impostos das áreas construídas, sendo portanto menos "rentáveis". Além disso, quando são entregues pelo empreendedor, tornam-se responsabilidade da administração pública, que deve arcar com sua manutenção.

Uma parte de tais problemas foi atenuada no Município de São Paulo a partir de 1981, quando a legislação ${ }^{17}$ passou a obrigar que $50 \%$ das áreas verdes reservadas no loteamento fossem escolhidas pelo Poder Público. Passou-se também a restringir a declividade máxima desses terrenos para um valor máximo de 30\%.

Apesar de tais aperfeiçoamentos, tal sistema continuou a permitir a produção de espaços livres fragmentados e funcionalmente inadequados, quando analisados em larga escala. A falta de uma gestão integrada ou unificada também contribui para que uma grande parte destes espaços seja desperdiçada, devido à inexistência de programas públicos para implementação de tais áreas.

O desinteresse conjunto da iniciativa pública e privada pela destinação dos espaços livres em parcelamentos seria reforçado em 1994, com a criação de uma nova categoria de uso do solo denominada conjunto residencial R3-03 $3^{18}$ (também conhecidas como "lei das vilas"). Nesse tipo de empreendimento, as áreas para circulação e estacionamento de veículos não são computáveis. Desse modo, torna-se mais vantajoso ao empreendedor incorporar áreas do seu loteamento como circulação, pois elas poderão ser utilizadas pelos futuros moradores. Caso essas áreas fossem computadas como construídas, uma parcela delas seria convertida em áreas verdes, sem proveitos imediatos para o empreendimento e com pouca chance de ser mantida adequadamente pelo Poder Público.

São Paulo. Tese de Doutorado. São Paulo: FAUUSP, 1999. p. 156

17. Lei Municipal no $9413 / 1981$

18. Criada pela Lei Municipal no $11.605 / 1994$ 


\section{Investimentos diretos e indiretos}

$\mathrm{Na}$ cidade de São Paulo, a maioria das obras necessárias para destinar um espaço livre ao uso recreativo ou de convívio (isto é, para se tornar uma praça ou um parque) são custeadas por investimento direto do Poder Público.

Sakata divide esses investimentos em três categorias distintas ${ }^{19}$. A primeira delas, definida como "ações rotineiras", corresponde aos projetos realizados por órgãos públicos, tais como secretarias de obras, de urbanismo ou meio ambiente. No caso do Município de São Paulo, enquadra-se nessa categoria a maioria dos projetos realizados pela prefeitura de São Paulo desde meados da década de $1960^{20}$.

Outra forma de investimento é denominada por Sakata como "programas políticos". Segundo a autora, estes projetos correspondem a um conjunto de obras promovidas por uma determinada gestão e "podem destinar-se a espaços menores ou maiores, a diferença é que visarão simultaneamente a diversos pontos, o que dá peso e visibilidade à ação" ${ }^{21}$. Um exemplo desse tipo de ação é o Programa Centros de Bairro.
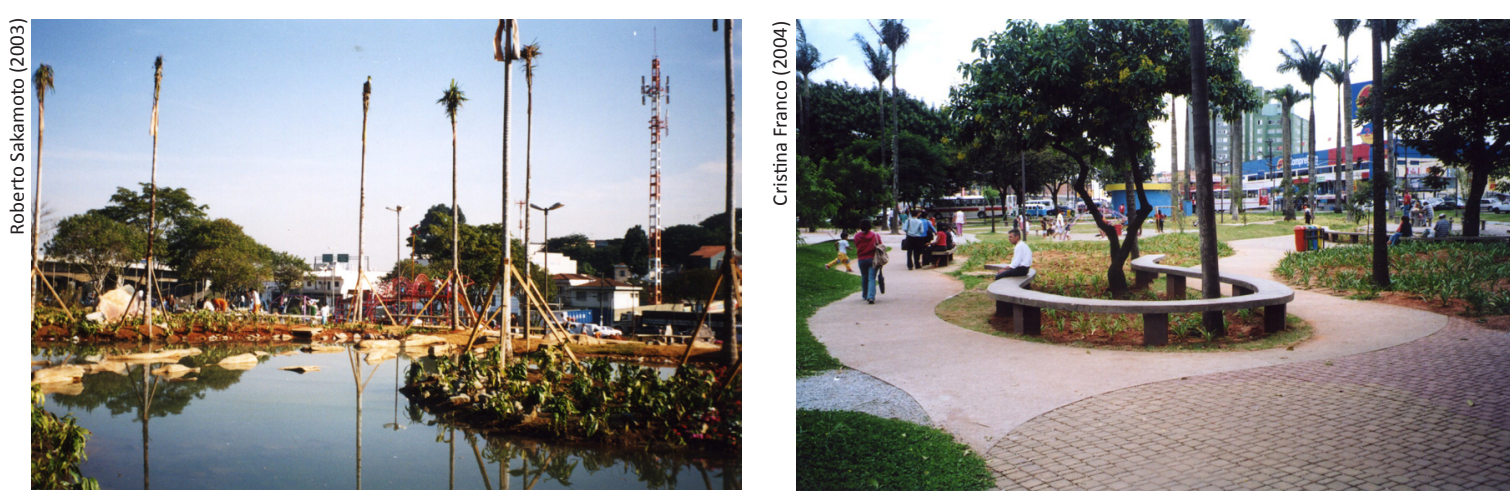

Por último, têm-se as ações denominadas como "excepcionais", que também possuem caráter político. São projetos sofisticados, feitos em menor quantidade e que envolvem custos maiores. Têm por objetivo tornarem-se referenciais de qualidade e visibilidade, que espelhem uma imagem positiva do administrador público. Por esse motivo "via de regra, passam pelo gabinete do prefeito ou do governador, que as inaugura pessoalmente" 22

Praças do Programa Centros de Bairro. À direita Praça General Milton Tavares (distrito de Vila Maria) e à esquerda Praça Felisberto Fernandes da Silva (Subprefeiitura de São Mateus)

19. SAKATA, Francine Gramacho. O projeto paisagístico como instrumento de requalificação urbana. Dissertação de Mestrado. São Paulo, FAUUSP, 2004. p. 46-47

20. Esses projetos foram realizados pela equipe do Departamento de Parques e Jardins (PARQUE) - posteriormente denominado Departamento de Parques e Áreas Verdes (DEPAVE) - e pelas equipes das subprefeituras (antigas Administrações Regionais). O histórico da atuação do DEPAVE será visto em maiores detalhes no capítulo 3.

21. SAKATA, Francine Gramacho. O projeto paisagístico como instrumento de requalificação urbana. Dissertação de Mestrado. São Paulo, FAUUSP, 2004. p.47

22. Ibidem. 


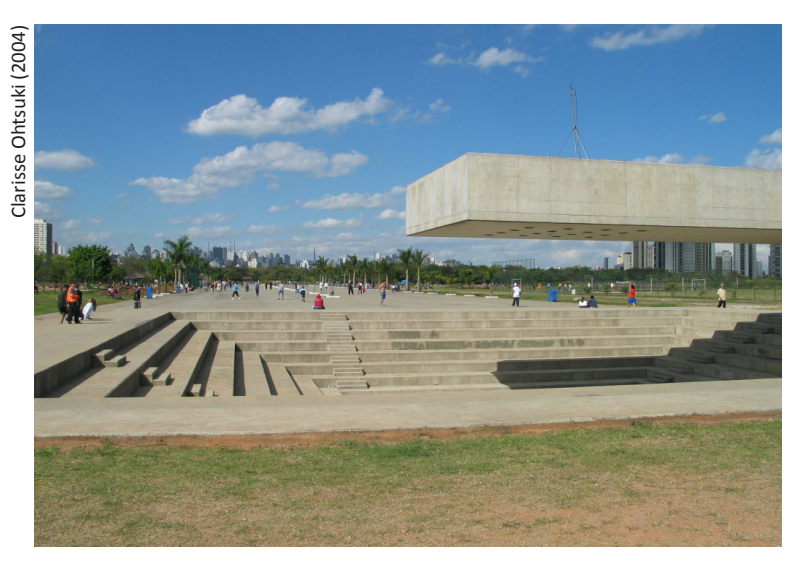

Da esquerda para a direita: Parque Villa Lobos, vista aérea do Parque da Juventude em São Paulo SP e Promenade Plantee (Paris - França)

23. Projeto de autoria do escritório da arquitetapaisagista Rosa Grena Kliass.
Diversos são os exemplos desse tipo de intervenção na cidade de São Paulo, dos quais se pode destacar a reurbanização do Vale do Anhangabaú, concluída pela prefeitura em 1992 e o Parque Villa Lobos, cuja primeira fase foi executada pelo Governo do Estado também no início dos anos 1990. Outro exemplo é o Parque da Juventude ${ }^{23}$, cuja primeira fase foi inaugurada pelo governo estadual no final do ano de 2003.

O Parque da Juventude, construído em área que abrigava parte do Complexo Penitenciário do Carandiru, exemplifica um tipo de ação para reabilitar áreas degradadas. Projetos desse tipo tendem a se tornar cada vez mais comuns, em decorrência da diminuição da quantidade de áreas para implantação de espaços livres públicos nas cidades brasileiras. Uma das principais virtudes desse tipo de intervenção é o fato de "gerar" espaços livres em locais de urbanização adensada, que dificilmente teriam possibilidade de produzi-los.
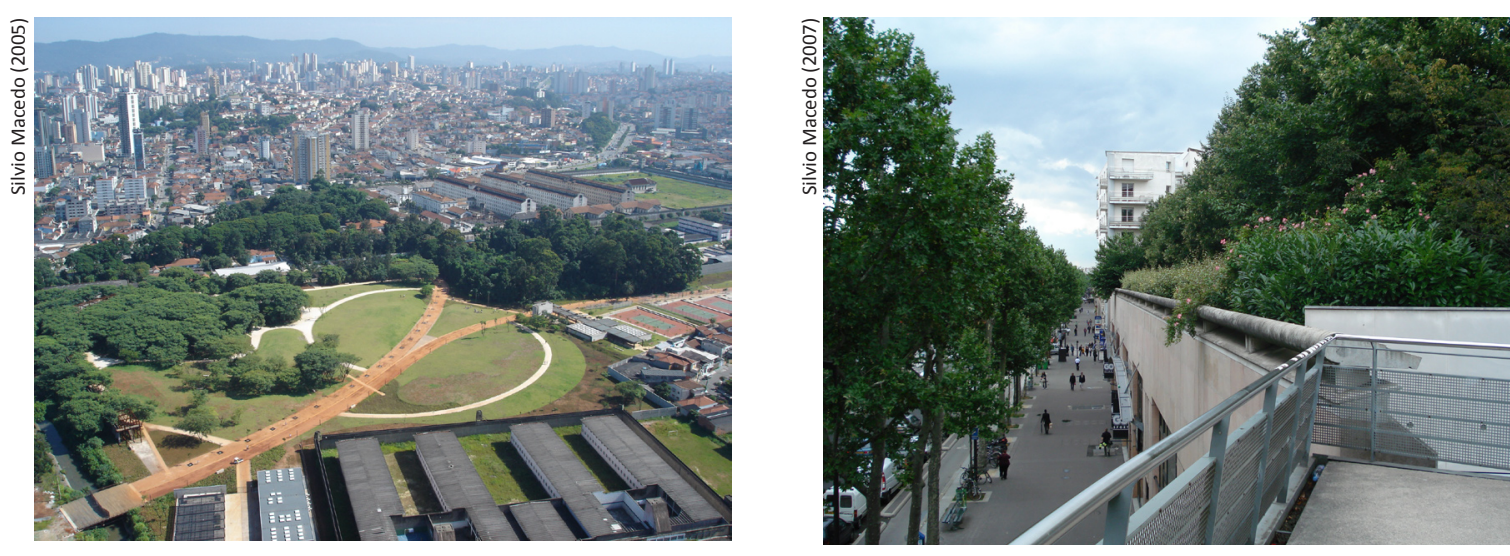

Tal prática já é corrente em países europeus, cujos espaços são tradicionalmente exíguos. Uma referência importante desse tipo de projeto é a Promenade Plantée, em Paris. Esse parque linear, inaugurado por partes a partir de 1988, foi construído no leito e vias elevadas de uma antiga linha ferroviária desativada. Outros exemplos são o Parc de la Villette construído no local de um antigo abatedouro público de Paris - e as áreas utilizadas para a Expo'98, edificada em um deteriorado bairro industrial de Lisboa. 
A produção de espaços livres públicos também pode ocorrer de forma indireta. Se, como já foi citado anteriormente, diversas áreas originalmente destinadas para espaços livres acabam sendo utilizadas com outras finalidades pelo Poder Público, o processo inverso pode ser benéfico. Equipamentos presentes nos Centros Desportivos Municipais (CDM), nos Centros Educacionais Unificados (CEU) e até mesmo nas escolas municipais e estaduais de São Paulo, podem auxiliar de forma indireta a suprir a carência de espaços livres na cidade. Embora não tenham prioritariamente a função de espaços recreativos e possuam uso mais restrito, o espaço livre de tais edificações reúne equipamentos como quadras esportivas, áreas de estar e playgrounds. Essa solução, naturalmente, é paliativa, pois abrir irrestritamente esses edifícios à população pode acentuar problemas para gestão dos equipamentos abrigados pela instituição.

\section{Manutenção e proteção dos espaços livres existentes}

Nenhuma das ações anteriormente enumeradas apresenta resultado satisfatório caso não seja realizada a manutenção adequada dos espaços livres gerados. Diversos deles têm sua funcionalidade comprometida ou até mesmo tornam-se inoperantes devido à falta de manutenção. Em termos práticos, manter um espaço livre sem uso equivale à sua inexistência e contribui para aumentar seu déficit na cidade.

O Município de São Paulo não possui uma estrutura adequada para a gestão de praças ${ }^{24}$. Tal fato reflete um dos maiores problemas relacionados aos espaços livres das grandes cidades brasileiras: a prioridade do Poder Público está na inauguração de novas obras. A manutenção dos espaços existentes - com raras exceções nas áreas centrais e bairros de elite - é tradicionalmente preterida, pois não traz retorno em visibilidade para os governantes. Desse modo, a durabilidade de novos espaços livres implantados - sobretudo os periféricos - fica atrelada ao tempo que eles conseguirão resistir sem manutenções e sujeitos a constantes ações de vandalismo.

Além disso, a implantação de um espaço livre, isoladamente, não garante o seu uso adequado. $\mathrm{O}$ estímulo de atividades por meio de programas específicos promovidos pelo Poder Público pode ser necessário para que ele desempenhe efetivamente sua função.
24. A gestão de parques públicos é relativamente melhor resolvida em relação às praças, devido à existência de administrações próprias. 
25. "Considerando que o mercado clandestino atende sobretudo à população mais pobre, há o efeito desastroso da própria lei, que acaba destinando as piores terras - ou vulneráveis do ponto de vista ambiental - justamente para quem tem menos condições de ocupá-la de forma mais segura" SÃO PAULO (Cidade), Secretaria Municipal do Verde e Meio Ambiente. Atlas Ambiental Municipa do Município de São Paulo. São Paulo: SVMA, 2002, p. 134

26. Cf. MAGNOLI, Miranda Martinelli. Espaços livres e urbanização: uma introdução a aspectos da paisagem metropolitana. Tese de livre-docência. FAUUSP, 1982.
Comparados aos espaços livres para fins recreativos, aqueles destinados à preservação de recursos naturais enfrentam dificuldades ainda maiores para manutenção. A delimitação de áreas ambientalmente protegidas tem se mostrado insuficiente no papel de conter a expansão da metrópole, justamente por restringir seu uso a ponto de deixá-las com poucas destinações específicas, em meio a um contexto de complexas dinâmicas sociais urbanas. Devido à sua localização predominantemente distante das áreas centrais e geralmente com grandes extensões, esses espaços livres sofrem pressões constantes do processo de urbanização do entorno ${ }^{25}$. A regulamentação restritiva do uso do solo por meio de áreas ambientalmente protegidas só apresenta efeitos práticos caso haja fiscalização adequada, o que não tem ocorrido na maioria dos casos.

\section{Ações da iniciativa privada e interações com o Poder Público}

Diante do reduzido investimento público em espaços livres recreativos, a iniciativa privada utiliza o mote do equipamento de lazer para a venda de seus produtos. Como resultado, a esfera privada explora como instrumento de marketing um elemento que poderia ser fornecido pelo Poder Público.

Naturalmente, a abrangência das ações privadas é restrita àqueles que possuem poder aquisitivo para custeá-la. E, mais que isso, a produção de espaços livres recreativos dentro da esfera privada tem resultado em padrões excludentes de urbanização, caracterizado pelo isolamento em relação ao restante da cidade. Desde a década de 1970, em seus estudos pioneiros sobre espaços livres no Município de São Paulo, Magnoli já apontava a desproporção entre a quantidade de espaços livres públicos e privados, com predominância deste último ${ }^{26}$.

Em algumas situações, mesmo atuando de forma isolada e fragmentada, a iniciativa privada contribui indiretamente para a atenuação da carência de espaços livres públicos.

A realização de melhorias no entorno de novos empreendimentos imobiliários ganhou força a partir de meados da década de 1990, e se tornou um procedimento cada vez mais 
comum na cidade de São Paulo. A gama de melhoramentos abrange desde a pintura das fachadas de edificações até reformas em espaços livres públicos, envolvendo implantação de equipamentos e plantio de árvores nas ruas do entorno. Tais medidas não possuem o objetivo de melhorar a qualidade de vida do entorno, mas sim agregar valor ou ao menos atenuar possíveis depreciações do empreendimento em jogo. $\mathrm{O}$ exemplo a seguir ilustra bem esse tipo de iniciativa:

"Um canteiro de cerca de $100 \mathrm{~m}^{2}$ na Avenida Duque de Caxias (centro de São Paulo) foi adotado pela construtora e incorporadora TPA. A área está localizada em frente ao estande de vendas de um de seus empreendimentos. A adoção não é uma compensação ambiental. 'O jardim degradado desvaloriza o lançamento', diz o diretor-geral da empresa, Mauro Teixeira Pinto, 40. O projeto de revitalização foi feito pela Subprefeitura da Sé, e sua execução vai custar à TPA em torno de R\$ 5.000." 27

Embora o exemplo supracitado constitua uma ação em área central da cidade, esse tipo de intervenção freqüentemente é realizado em locais cujo alto poder aquisitivo dos compradores do empreendimento contrasta com seu entorno. É o caso de bairros paulistanos como Vila Andrade, designada pelo mercado imobiliário como sendo "Morumbi Sul"28:

$\mathrm{Na}$ Vila Andrade (região sul de São Paulo), três praças foram adotadas pela empresa CCDI (Camargo Correa Desenvolvimento Imobiliário), que constrói três condomínios no distrito. A recuperação das praças, que totalizam uma área de $21.186 \mathrm{~m}^{2}$, custou $\mathrm{R} \$ 350$ mil. A manutenção está orçada em $R \$ 10$ mil por mês, e o prazo, renovável, de adoção é de três anos - o mesmo período em que devem ser concluídas as obras dos edifícios. ${ }^{29}$

Outra atuação indireta da iniciativa privada ocorre na construção de edifícios corporativos, cujos espaços de acesso podem configurar praças abertas ao uso público ${ }^{30}$. A construção desse tipo de edifício na cidade de São Paulo acentuou-se a partir da década de 1970, difundindo-se ao longo dos eixos comerciais do centro expandido: inicialmente em alguns pontos da Avenida Paulista e posteriormente na Avenida Brigadeiro Faria Lima e na Avenida Eng. Luís Carlos Berrini ${ }^{31}$. O modelo para as tipologias utilizadas em São Paulo baseia-se na experiência norte-americana, sobretudo de cidades como Nova Iorque ${ }^{32}$, Los Angeles e Chicago.
27. Pacote de atrativos inclui praça e canteiro. Folha de São Paulo. Caderno Imóveis. 01 Abril 2007.

28. Este processo, cada vez mais freqüente, utiliza-se da mudança do nome de bairros fazendo alusão às áreas mais valorizadas da adjacência, como forma de atrair novos compradores. Pacote de atrativos inclui praça e canteiro. Folha de São Paulo. Caderno Imóveis. 01 Abril 2007.

30. Cf. HEPNER, Alexandre. Espaços livres na arquitetura corporativa: desenho e morfologia urbana nas centralidades teriáris de Săo Paulo. Relotorio de Pesquisa FAPESP. São Paulo:

31. Cf. FRÚGOLI Jr., Heitor. Centralidades em São Paulo. São Paulo: Edusp, 2000.

32. Cf. KAYDEN, Jerold S. Privately Owned Public Space: The New York City Experience. New York, John Wiley \& Sons, 2000. 
$\mathrm{Na}$ maioria dos projetos de praças corporativas, o caráter público do uso é restrito. É o caso dos edifícios Citibank e Cetenco Plaza ${ }^{33}$, na Avenida Paulista e do edifício do Banco Itaú ${ }^{34}$ na Avenida Eng. Luís Carlos Berrini.

À esquerda, praça de entrada do Edifício Plaza, na Av. Paulista. A direita, jardim do edifício do Banco Itaú (antigo Bank Boston) na Av. Eng. Luís Carlos Berrin
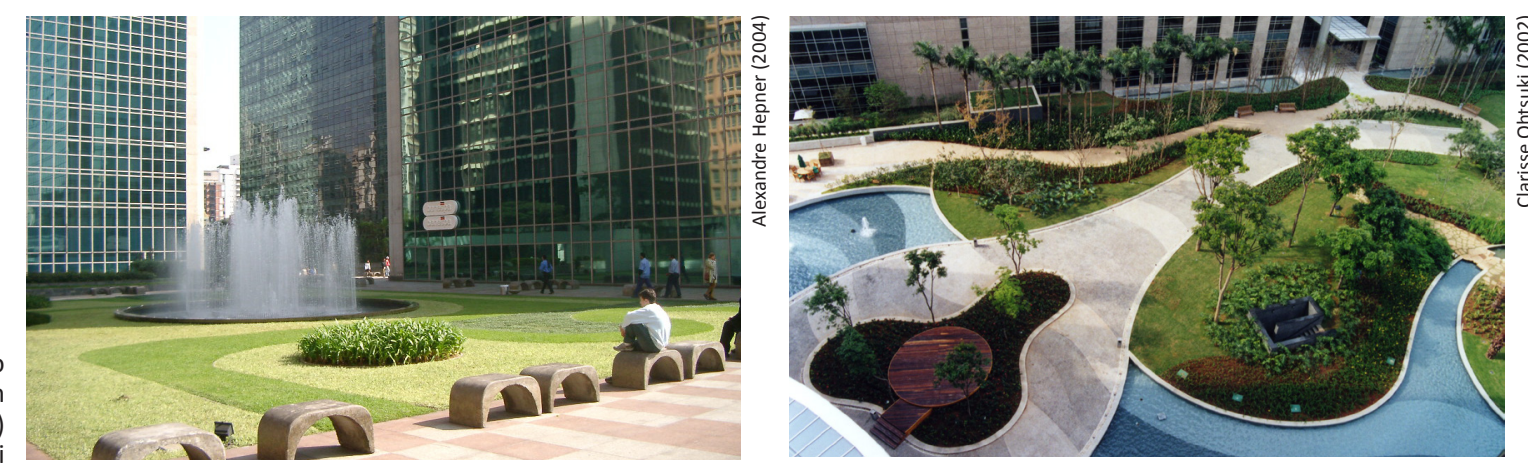

Constituem exceções a esse processo restritivo os jardins do Centro Corporativo do Itaú Conceição ${ }^{35}$, que se interligam aos acessos do metrô e o Edifício Brascan ${ }^{36}$, que apresenta a configuração de um centro de compras ao ar livre.

33. Projeto paisagístico inicial do escritório do arquitetopaisagista Luciano Fiaschi.

34. Antigo edifício do Bank Boston. Projeto do escritório da arquiteta-paisagista Isabel Duprat.

35. Projeto da equipe Itauplan

36. Projeto do escritório do arquiteto-paisagista Benedito Abbud
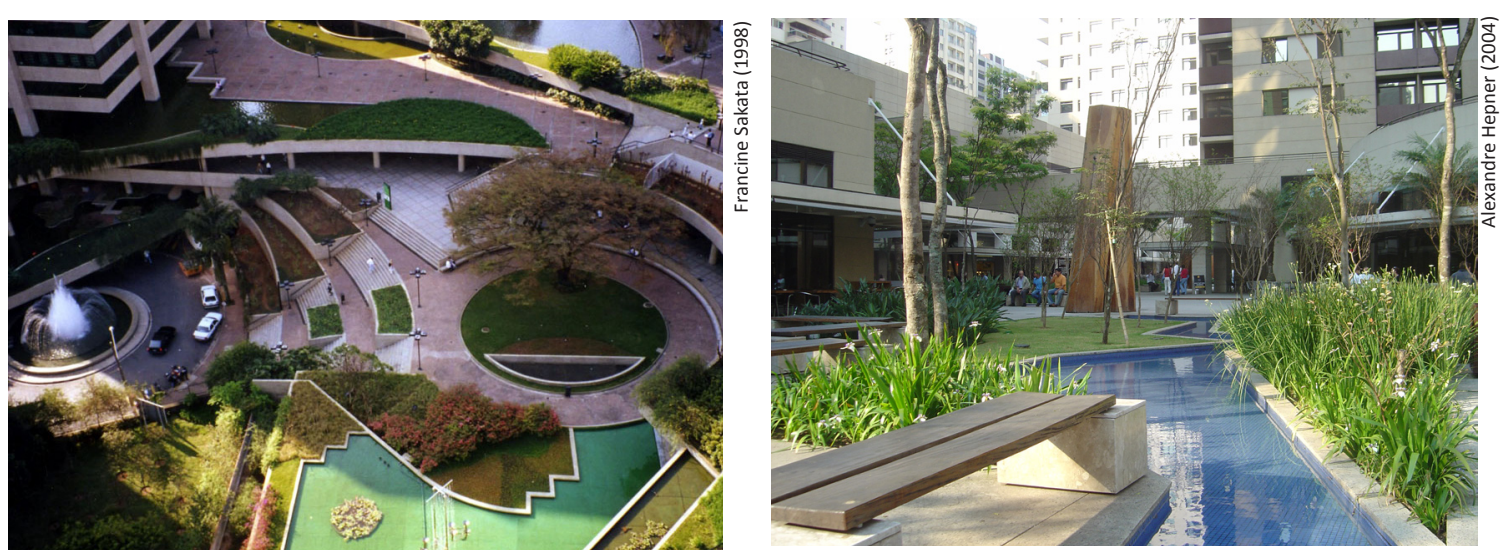

O Poder Público também pode estabelecer diversas formas de interação com a iniciativa privada visando captar recursos para construir, gerir e manter espaços livres. Tal prática é inclusive incentivada pelo Plano Diretor Estratégico do Município. No capítulo sobre Meio Ambiente, subseção "Áreas Verdes", uma das diretrizes enumeradas é "a criação de 
instrumentos legais destinados a estimular parcerias entre os setores público e privado para implantação e manutenção de áreas verdes e espaços ajardinados ou arborizados"37.

A manutenção de espaços livres públicos em troca de publicidade é uma das formas mais usuais de cooperação entre a esfera pública e privada. O processo de adoção de uma praça ou parque costuma vincular-se à visibilidade que este local possua, de modo semelhante ao que ocorre com os espaços priorizados pelo próprio Poder Público. Locais como o Parque do Ibirapuera, canteiros da região da Avenida Paulista, Jardins ou Centro Histórico são os preferidos das empresas patrocinadoras e por vezes chegam a ter disputa por um mesmo espaço para publicidade.

Por outro lado, áreas que não oferecem possibilidades imediatas de retorno financeiro à empresa patrocinadora - ou mesmo ao Poder Público - raramente são adotadas. Por esse motivo, a capacidade de contribuição desse tipo de ação é bastante limitada. Os espaços livres menos atrativos à iniciativa privada - tais como praças em regiões periféricas ou com avançado estado de degradação - costumam ser justamente aqueles que necessitam de mais atenção e maiores investimentos financeiros para serem recuperados.

Em algumas situações a iniciativa privada pode custear diretamente o projeto e construção de novos espaços livres públicos. Essa atuação pode ocorrer tanto de forma associada ao Poder Público, através de parcerias, quanto isoladamente.

As parcerias são firmadas por motivações semelhantes às adoções de espaços livres públicos: relacionam-se a retornos em benefícios para a empresa, tais como visibilidade ou concessões de espaço para publicidade.

O termo de cooperação é o principal instrumento existente na cidade de São Paulo para iniciativas do gênero. Na maioria dos casos, o acordo realizado consiste na manutenção de um espaço livre às custas de uma instituição privada por determinado período de tempo, durante o qual o Poder Público encarrega-se de fiscalizar o serviço prestado. Dentre os inúmeros exemplos desse tipo de acordo na cidade de São Paulo, pode-se destacar a Praça Vinícius de Moraes, no bairro do Morumbi ${ }^{38}$.

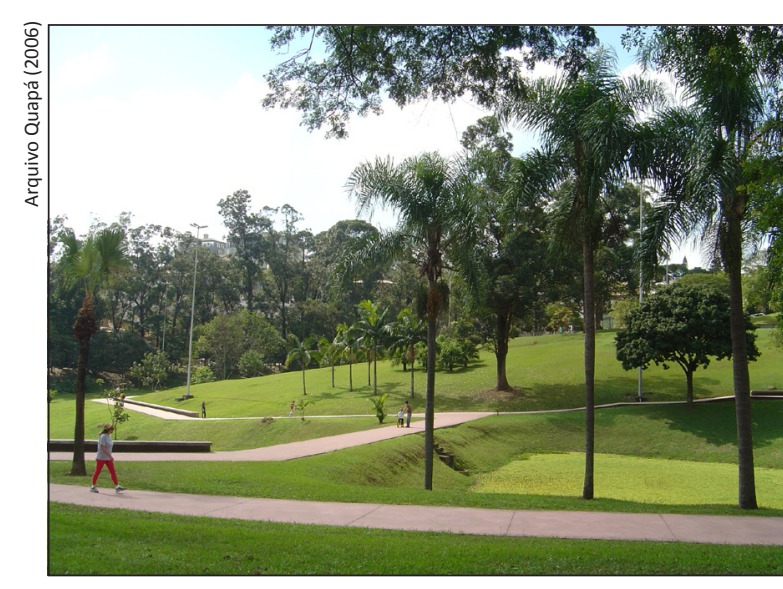

Praça Vinícius de Moraes, bairro do Moumbi. O espaço livre público é mantido por meio de sucessivos Termos de Cooperação assinados com a Subprefeitura do Butantã.

37. Lei Municipal 13.430/2002. Cap. III, art. 59, §V 38. Localizada em área de grande visibilidade e alto poder aquisitivo, a praça tem sido mantida (até o ano de 2008) po sucessivos Te Butantã. 
Em casos mais raros, a execução completa de um espaço livre pode ser viabilizada por termo de cooperação. É o caso do Parque Vila do Rodeio, localizado no bairro de Cidade Tiradentes, cuja primeira fase foi concluída no ano de $2003^{39}$.

Tendo em vista o caráter promissor que os custeios pela iniciativa privada apresentam, a busca pelo estabelecimento de parcerias com a iniciativa privada constituiu a prioridade inicial da Secretaria Municipal do Verde e Meio Ambiente (SVMA) durante a gestão Marta Suplicy na prefeitura de São Paulo (2000-2004). As tentativas não foram bem sucedidas ${ }^{40}$ devido ao desinteresse da iniciativa privada em áreas sem a visibilidade desejada.

\section{Uma nova alternativa}

As atuações isoladas do Poder Público e da iniciativa privada para amenizar o déficit de espaços livres públicos no município não têm sido bem sucedidas. A associação de ambos, embora promissora, também não tem surtido os efeitos desejados, pois se vincula excessivamente aos interesses da iniciativa privada.

Se a associação voluntária apresenta problemas, o estabelecimento de um vínculo legal abriu espaço para novos tipos de negociações entre o Poder Público e o empreendedor.

No final dos anos 1990, as compensações ambientais arbóreas surgem na cidade de São Paulo como uma nova forma de interação entre o Poder Público e a iniciativa privada. Consolidada como mecanismo legal, a compensação tornou-se uma forma alternativa de captação de recursos para viabilizar novos espaços livres no município. Este é o objeto de estudo deste trabalho. 
CAPÍTULO II

Compensações ambientais: uma abordagem conceitual 



\section{Introdução}

A compensação ambiental é a medida mais extrema dentre três ações usualmente adotadas em situações relacionadas a danos ao meio ambiente: evitar, mitigar ou compensar.

Em uma escala gradativa de proteção ambiental, a medida prioritária e mais desejável é a prevenção, pela qual se busca evitar que um dano se concretize. Essa ação é realizada principalmente por meio do planejamento antecipado.

Caso a ocorrência de um dano ambiental seja inevitável, recorre-se à mitigação, que consiste em atenuar suas possíveis conseqüências. A redução na emissão de poluentes é um exemplo de medida mitigadora.

Se a mitigação mostrar-se inviável ou caso o dano já tenha sido causado, utiliza-se como último recurso a compensação ambiental. Ela consiste em um mecanismo financeiro que estabelece uma indenização prévia ou posterior à realização de um dano ao meio ambiente.

A compensação por indenização prévia é estabelecida durante o processo de aprovação de um empreendimento. Ela resulta de uma negociação com o Poder Público, que atribui um valor de contrapartida aos danos ambientais causados pelo empreendimento, seja ele privado ou público.

No Brasil, a determinação do valor compensatório deve ser realizada no processo de licenciamento ambiental. O pagamento da quantia estabelecida pelo Poder Público descriminaliza um dano específico causado pelo empreendedor.

Isso não significa, naturalmente, o custeio de um “direito de poluir”. O princípio norteador das compensações é estabelecer contrapartidas altas o suficiente fazer o empreendedor repensar ações futuras. Além disso, o Poder Público pode, por meio do licenciamento, até mesmo vetar a realização de um empreendimento, caso o considere inadequado. 
Caso o pagamento da compensação seja posterior ao dano causado, ela passa a ser denominada reparação, correspondendo a um mecanismo de ajustamento de conduta $^{41}$. Tal procedimento não será aprofundado neste trabalho.

Em qualquer uma de suas duas modalidades (compensação ou reparação), o ato de compensar implica na autorização de um dano ambiental pelo Poder Público. Por esse motivo, a compensação também é conhecida como uma tecnologia "end of pipe" (ou ponta de chaminé, em inglês). Tal analogia refere-se ao fato de que compensar é uma medida ambientalmente paliativa. Ela equivale à colocação de um filtro ao final de todo o processo produtivo, para amenizar os efeitos nocivos dos gases de uma indústria. A situação mais adequada ambientalmente consistiria em uma ação preventiva, tal como o uso de uma tecnologia com emissão reduzida ou nula de poluentes.

Os danos ambientais aqui mencionados podem ser os mais diversos, tais como a contaminação de solos e recursos hídricos, a emissão de gases poluentes na atmosfera ou a retirada de vegetação. $\mathrm{O}$ foco deste trabalho são os danos ambientais causados à vegetação, mais especificamente, à cobertura arbórea.

No caso específico da retirada de vegetação, a medida compensatória mais intuitiva seria pela mesma "moeda de troca". Ou seja, o plantio de novas mudas. Mas existem diversas formas alternativas para compensação arbórea, que serão aprofundadas ao longo deste trabalho. 


\section{Neutralização: a compensação ambiental apropriada como marketing e modismo}

A compensação ambiental arbórea e a neutralização apresentam relação muito próxima. Ambas estabelecem trocas, o que muda é a "moeda" utilizada para a negociação. A compensação arbórea troca árvores por árvores (ou, dependendo do caso, por outros elementos). A neutralização estabelece a troca da poluição atmosférica com gás carbônico por árvores, partindo do princípio que estas conseguem absorvê-lo em parte. Alguns percalços encontrados na aplicação das neutralizações apresentam semelhança com aqueles encontrados para a compensação ambiental arbórea.

O conceito de neutralização foi proposto pela primeira vez no ano de 1997 pela empresa britânica CarbonNeutral, cuja proposta era gerenciar esse tipo de compensação e, evidentemente, lucrar com o processo. A partir de então, surgiram inúmeras empresas que realizam cálculos para definir quantas árvores são necessárias para "retirar" da atmosfera o gás carbônico provenientes das mais diversas atividades antrópicas.

Ao longo dos onze anos de sua aplicação, a neutralização foi sendo gradativamente valorizada pela mídia. Entre os principais divulgadores do conceito encontra-se Al Gore, ex-vice-presidente dos Estados Unidos, além de vários artistas que desejam veicular a imagem de compromisso com causas ambientais.

A neutralização também foi apropriada por incautos como uma espécie de amenização da culpa pela degradação humana do meio ambiente, que foi intensificada após o alarmismo gerado pela divulgação do Relatório do IPCC (Painel Intergovernamental sobre Mudanças Climáticas) no ano de 2007. O trecho a seguir ilustra bem esse raciocínio:

Na última quarta, a aposentada Cecília Martinez, 66, repetiu mais uma vez uma atitude que vem praticando desde 2000. Plantou uma árvore. Até semana passada, ela calcula ter repetido o gesto por 1.900 vezes. [...]. Bastou um rápido clique no mouse. 'Levanto cedo, vou para o computador, planto as árvores e fico com a consciência mais leve', conta Cecília. 'Não entendo muito sobre 
42. KÜCHLER, A. Caos ecológico leva pessoas a neutralizarem culpa e carbono. Folha de São Paulo. Caderno Cotidiano. 26 agosto 2007.

43. " O casal de arquitetos Renato Barandier, 27, e Izabella

Lentino, 30, preferiu ir além da mesa do computador. No final de outubro, eles vão fazer de seu casamento, em Niterói (RJ), um evento "carbon free" -para usar um termo tão em voga', un pensamos nos caminhões trazendo vinho do Sul, nos convidados vindos da Alemanha e de Brasília, achamos que tínhamos de fazer alguma coisa para compensar o impacto', diz Renato Para minimizar o estrago ambiental provocado pe nnião, eles irão plantar árvores. Quantas, o casal ainda não sabe. Eles contrataram a empresa Carbono Neutro para fazer sabe. El Plantio e acompanhamento do crescimento das plantas tambem

44. Portaria no 06 /SVMA.G/2007

45. BORSATO, Cíntia. A neutralização da culpa. Revista Veja. 21 de fevereiro de 2007 aquecimento global. Mas acompanho o tema e sei que sou parte do problema. A gente sente culpa, e comecei a fazer isso para aliviar um pouco a consciência'. A aposentada é uma das principais jardineiras eletrônicas de um site ligado ao projeto SOS Mata Atlântica, em que internautas podem plantar árvores bancadas por empresas. ${ }^{42}$

O grau de especialização desse tipo de negócio expandiu de tal modo que hoje em dia é possível encontrar empresas que oferecem cotas de neutralização para as mais variadas atividades, tais como compra de veículos, viagens aéreas, eventos como palestras e espetáculos musicais ou mesmo casamentos ${ }^{43}$.

Na cidade de São Paulo, a neutralização foi institucionalizada por meio de uma Portaria ${ }^{44}$ emitida pela Secretaria do Verde e Meio Ambiente (SVMA) em 2007, segundo a qual todos os eventos realizados em parques públicos municipais devem gerar o plantio de mudas para compensar as emissões de carbono deles provenientes.

Empresas que realizam neutralizações buscam explorar ao máximo a imagem de compromisso com o meio ambiente. No ano de 2007 tornaram-se corriqueiros os anúncios publicitários de televisão nos quais o produto vendido pela empresa (em geral, algo bastante agressivo ao meio ambiente, como detergentes ou combustíveis) transforma-se em árvores quando adquirido pelo consumidor, formando gradativamente uma bucólica floresta.

Apesar da apologia realizada pela mídia, o uso generalizado da neutralização como forma de atenuar danos ambientais é inviável por várias razões. A primeira delas é a limitação de espaço disponível: compensar efetivamente a emissão global de poluentes na atmosfera terrestre demandaria o plantio de árvores em uma superfície superior à do planeta inteiro $^{45}$. Existem soluções bem mais eficientes para o problema, tal como investimento em tecnologias alternativas, redução das emissões de poluentes, mudanças no padrão de consumo, entre outros.

Além disso, os benefícios efetivos da troca da emissão de poluentes pelo plantio de árvores dependem diretamente do local onde este será efetuado e da manutenção adequada dessas 
novas mudas. Caso as mudas não sobrevivam ou sejam plantadas em local inadequado, o único beneficiário da neutralização será a empresa que a realizou, visto que lucrará com a intermediação do processo.

Esse lucro, por sinal, pode ser bastante elevado, pois não existe padronização da quantia a ser compensada. Dados apontam uma discrepância de até 300\% nos valores calculados pelas principais empresas de neutralização atuantes no $\mathrm{Brasil}^{46}$.

E a tão divulgada retirada de poluentes da atmosfera por parte das mudas plantadas evidentemente não será plena de forma imediata. Ela está sujeita ao crescimento de árvores que, caso sobrevivam, podem levar até trinta anos para atingir a maturidade. E o processo de neutralização só será efetivo mediante sua continuidade: árvores plantadas hoje que não forem repostas, anularão a ação realizada.

O sucesso do conceito de neutralização perante a opinião pública evidencia que uma parte da sociedade humana está muito mais disposta a atenuar a crise ambiental existente por meio de instrumentos paliativos, ao invés de buscar soluções estruturais para o problema. Este mesmo princípio embasa a aplicação dos créditos de carbono ${ }^{47}$. Curioso notar que as próprias empresas que comercializam serviços de neutralização divulgam em seus websites que o investimento em tecnologias alternativas constitui uma solução mais relevante para atenuação da poluição do que o serviço por elas vendido ${ }^{48}$
46. GERAQUE, Eduardo. Neutralização de CO2 esbarra em método. Folha de São Paulo. Caderno Ciência. 29 dezembro 2007

47. O conceito de crédito de carbono parte do princípio que "cada tonelada de $\mathrm{CO} 2$ deixada de ser emitida ou retirada da atmosfera por um país em desenvolvimento poderá ser negociada no mercado mundial [...]. . ROCHA, Marcelo Teotho. Aquecimento Global e Mercado de Carbono - Uma aplicação do modelo CERT. Tese de Doutorado. Pricicaba: Escola Superior de Agricultura Luiz de Queirós, 2003. p. 9

48. 0 site da empresa Carbon Neutral (criadora do conceito de neutralização) divulga que o plantio de árvores constitui apenas $20 \%$ dos recursos por ela direcionados para neutralização, sendo prioritário o investimento em pesquisa de tecnologias energéticas alternativas. 
49. NOGUEIRA, J. M.; MEDEIROS, M. A. A. Quanto vale aquilo que não tem valor? Valor de existência, economia e meio ambiente. In: Cadernos de Ciência \& Tecnologia, Brasília, v.16, n.3 p. 78 set./dez. 1999

50. SEROA DA MOTTA, R. Manual para valoração econômica de recursos ambientais. Brasília: Ministério do Meio Ambiente, 1998. p. 1

\section{Valoração ambiental: o enfoque econômico das compensações}

O princípio para aplicação das compensações ambientais remete ao conflito entre atividades econômicas e a preservação de recursos naturais. Ao realizar uma compensação, partese do pressuposto que determinados recursos naturais são passíveis de troca, em função das diversas demandas que a ocupação humana exige. Constitui uma situação complexa definir como e quando essa troca pode ser realizada. Um recurso natural que atualmente não apresenta relevância pode passar a tê-la a partir de algum momento.

Os critérios para definição dos recursos passíveis de compensação costumam ser arbitrários e na maioria das vezes obedecem a motivações econômicas. Por trás desses critérios, permeia o ideário de uma sociedade imediatista, segundo a qual a paisagem pode ser remodelada conforme os interesses econômicos em jogo:

Em qualquer sociedade diversificada é inevitável que um símbolo cultural, religioso ou ambiental encarado favoravelmente por um grupo possa ser visto desfavoravelmente por um outro grupo. Para alguns, o estabelecimento de uma nova reserva biológica ou indígena pode ser entendido como um desperdício deliberado de boa madeira e/ou de recursos minerais valiosos. ${ }^{49}$

A melhor aproximação para atenuar os conflitos entre economia e meio-ambiente neste início de século é o conceito de valoração ambiental. Segundo Seroa da Motta, "Determinar o valor econômico de um recurso ambiental é estimar o valor monetário deste em relação aos outros bens e serviços disponíveis na economia" ${ }^{50}$. A partir dos anos 1990, o conceito de valoração ganha relevância dentre os critérios para determinação dos custos do patrimônio ambiental.

No caso específico das compensações arbóreas, existem distintas alternativas para abordar o problema, dependendo se ele ocorre em áreas rurais ou urbanas.

Em áreas rurais, os conflitos gerados pela remodelação da paisagem com a retirada de árvores são ocasionados pelo valor de consumo desse recurso natural. A "moeda de troca" 
das compensações ambientais arbóreas em áreas rurais usualmente é a própria árvore, devido ao valor econômico que ela representa como matéria prima.

As atividades de reflorestamento realizadas por empresas de grande porte no Brasil ilustram como o meio ambiente tem sido remodelado em função dos interesses econômicos. $\mathrm{O}$ empobrecimento de ecossistemas inteiros e o enfraquecimento de determinadas atividades agrícolas locais em função do plantio de eucaliptos por empresas de grande porte constitui um problema ambiental de relevância cada vez maior no Brasil ${ }^{51}$.

Embora a remoção arbórea tenha relevantes implicações ambientais e sociais, a preservação de árvores relaciona-se ao dilema entre a extração imediata, a preservação ad infinitum, o uso sustentável ou a manutenção de um recurso natural para o consumo por gerações posteriores. Um avanço para atenuar esse conflito ocorreu a partir da incorporação do conceito de valor de existência nas questões de valoração ambiental. Ele é definido como a "parte do valor de um bem ou serviço ambiental que independe do seu uso presente ou futuro por seres humanos vivos ou ainda por nascer. ${ }^{52}$ "

Em áreas urbanas, a questão do valor pelo extrativismo vegetal cede lugar às questões relacionadas com o valor de uso da terra. Entram em jogo os interesses de ocupação pelo mercado imobiliário dos terrenos com vegetação remanescente, seja ela primária ${ }^{53}$ ou não. A questão que ganha força é a redução do estoque de espaços livres disponíveis, disputados com intensidade pelo mercado imobiliário.

Além do valor associado ao uso da terra, podem-se enumerar outros diversos valores associados à arborização das cidades. Detzel enumera seis variáveis econômicas a serem consideradas para a valoração ambiental de árvores urbanas ${ }^{54}$ :

- Valores monetários da arborização e legislação - item de maior pertinência a este trabalho. Considera o valor indenizatório a ser pago por danos à vegetação, seja por compensação ou por reparação. Detzel destaca que na maioria das vezes, este valor é estabelecido de forma empírica pelas prefeituras brasileiras.
51. "No Extremo Sul da Bahia a introdução da cultura do eucalipto vem trazendo sérios riscos para os recursos hídricos, o solo, a fauna e a flora locais, contribuindo também para a inviabilidade da agricultura familiar na região, ocupando todas as terras agricultáveis, inclusive em áreas que seriam destinadas a reforma agrária, terras indígenas e no entorno de Unidades de Conservação com importantes reservas de Mata Atlântic Concomitantemente as fábricas de celulose promovem um uso abusivo de água potável, além de lançar resíduos nos rios da região." SANTOS, C. S.; SILVA, J. L. C. Os impactos do plantio de eucalipto e da produção de celulose em comunidades tradicionais no extremo sul baiano. In: II Encontro da Associação Nacional de Pós-Graduação e Pesquisa em Ambiente e

Sociedade. Indaiatuba: ANPPAS, 2004

52. MEDEIROS, M. A. A.; NOGUEIRA, J. M. Quanto vale aquilo que não tem valor? Valor de existência, economia e meio

ambiente. In: Cadernos de Ciência \& Tecnologia, Brasília, v.16, n.3 p. 64 set./dez. 1999

53. Segundo o artigo 1ำ da Resolução CONAMA 001 de 1994, na Mata Atlântica que cobre o Estado de São Paulo, considera-se como primária "aquela vegetação de máxima expressão local, com grande diversidade biológica, sendo os efeitos das ações antrópicas mínimos, a ponto de não afetar significativamente suas características originais de estrutura e de espécie".

54. DETZEL, V. A. Arborização urbana: importância e avaliação econômica. In: Congresso Brasileiro de Arborização Urbana, 1 1992, Vitória. Anais I. Vitória: Prefeitura Municipal de Vitória, 1992. p.39-52. 
55. “[...] a Natureza é um objeto cultural, uma idéia, uma significação e não uma simples coisa externa." CHAUÍ, Marilen Natureza, Cultura, Patrimonio Ambiental. In: Lanna, A. L. D. (coord.) Meio ambiente: patrimônio cultural da USP. São Paulo: EDUSP: 2003. p.55
- Valores alternativos - comparação do custo da arborização urbana em relação a outros tipos de investimento, tais como mercado imobiliário ou de capitais.

- Árvores como bens de capital urbano - considera as árvores como outros quaisquer elementos da infra-estrutura urbana, tais como postes de transmissão de energia, escolas e hospitais.

- Valor de biomassa ou subproduto - conceito ligado ao extrativismo vegetal. Considera os potenciais produtos a serem obtidos a partir das árvores, tais como carvão, lenha, madeira serrada, extratos diversos.

- Valor de propriedade - considera que a existência de arborização em um terreno urbano ou no seu entorno pode elevar o preço de um imóvel ou terreno.

- Valores de manutenção - custo ligado ao controle de doenças e pragas, poda de limpeza e reparação de danos causados à infra-estrutura urbana (tais como guias, calçadas e fiação elétrica). $\mathrm{O}$ autor ressalta a importância desse componente de custo para o planejamento anual de manutenção arbórea pelos órgãos públicos e também para determinar valores de indenização por danos causados. Segundo Detzel, esse é um dos componentes mais largamente utilizados no processo de valoração.

Embora exista toda uma base conceitual para os cálculos econômicos da valoração ambiental arbórea, é difícil conceber que exista um valor de troca que corresponda de forma precisa ao dano causado. A relação da vegetação com o entorno é única, e por princípio, não passível de ser ressarcida.

O caráter da compensação ambiental será sempre parcial, porque acima dos valores financeiros ou dos efeitos ambientais que a retirada de uma árvore possa representar, existirão as implicações culturais ${ }^{55}$ estabelecidas pela mesma com a paisagem do entorno. Estas relações não poderão ser recuperadas por meio do plantio de novas mudas, mesmo que este preveja o plantio em local próximo ao dano e com quantias compensatórias maiores que as originárias. As novas mudas plantadas exigem um tempo de maturação e nem sempre podem ser plantadas no entorno imediato do local que gerou a compensação. 


\section{Arborizar é a Solução?}

No contexto urbano brasileiro, o papel desempenhado pela arborização só pode ser entendido adequadamente quando associado aos espaços livres que a ela dão suporte. $\mathrm{O}$ plantio de árvores adquire diferentes significados caso ocorra em uma via pública, à beira de um curso d'água ou em logradouros como praças, jardins e parques.

A compreensão do papel da arborização em espaços livres urbanos passa pela reflexão dos critérios de qualificação da paisagem, que segundo Macedo podem ser ambientais, estéticos e funcionais ${ }^{56}$, sendo este último extremamente vinculado ao cotidiano das cidades.

$\mathrm{Na}$ maioria das vezes, estes três elementos são analisados de forma fragmentada pela população, dando margem a diversos equívocos. Trabalhar com qualquer um desses critérios de forma isolada representa uma abordagem reducionista. $\mathrm{O}$ trecho a seguir reflete esse tipo de situação:

Em janeiro [do ano de 2008], foram inaugurados três parques municipais na cidade - entre eles, o Jacintho Alberto [...], em Pirituba. Beleza. Se a promessa for cumprida, São Paulo terá 66 parques e 18,6 milhões de metros quadrados de áreas verdes (hoje são 16 milhões de metros quadrados). Mas é pouco. A Secretaria do Verde e Meio Ambiente estima que sejam necessários no mínimo 100 parques para atenuar os impactos das mudanças ambientais na capital. ${ }^{57}$

Nesse exemplo, utiliza-se apenas o critério ambiental (possivelmente associado ao modismo vigente da neutralização de carbono) para reivindicar a necessidade de mais espaços livres no Município de São Paulo, esquecendo-se de mencionar a importância estética e funcional que estes também desempenham para as cidades. A esse respeito, Pereira afirma que:

O uso da vegetação na cidade, não pode ser visto como um acessório ou mero resultado aritmético dos efeitos do balanço de oxigênio, da melhoria da qualidade do ar, e de seus atributos físicoquímicos, que preenchem as brechas dos espaços construídos. As plantas são elementos indicadores e de controle da idade da cidade e da qualidade do meio ambiente, e são responsáveis, em uma determinada área, pela própria percepção do espaço projetado. ${ }^{58}$
56. MACEDO, Silvio Soares. Quadro do paisagismo no Brasil. São Paulo: FAUUSP, 2000. p. 13

57. VEIGA, Edison. Quando chegaremos a 100 parques? Revista Veja São Paulo. 06 fev. 2008 p.20

58. PEREIRA, Raul Isidoro. O sentido da paisagem e a paisagem consentida. Tese de Doutorado. São Paulo: FAUUSP, 2007. p. 90 

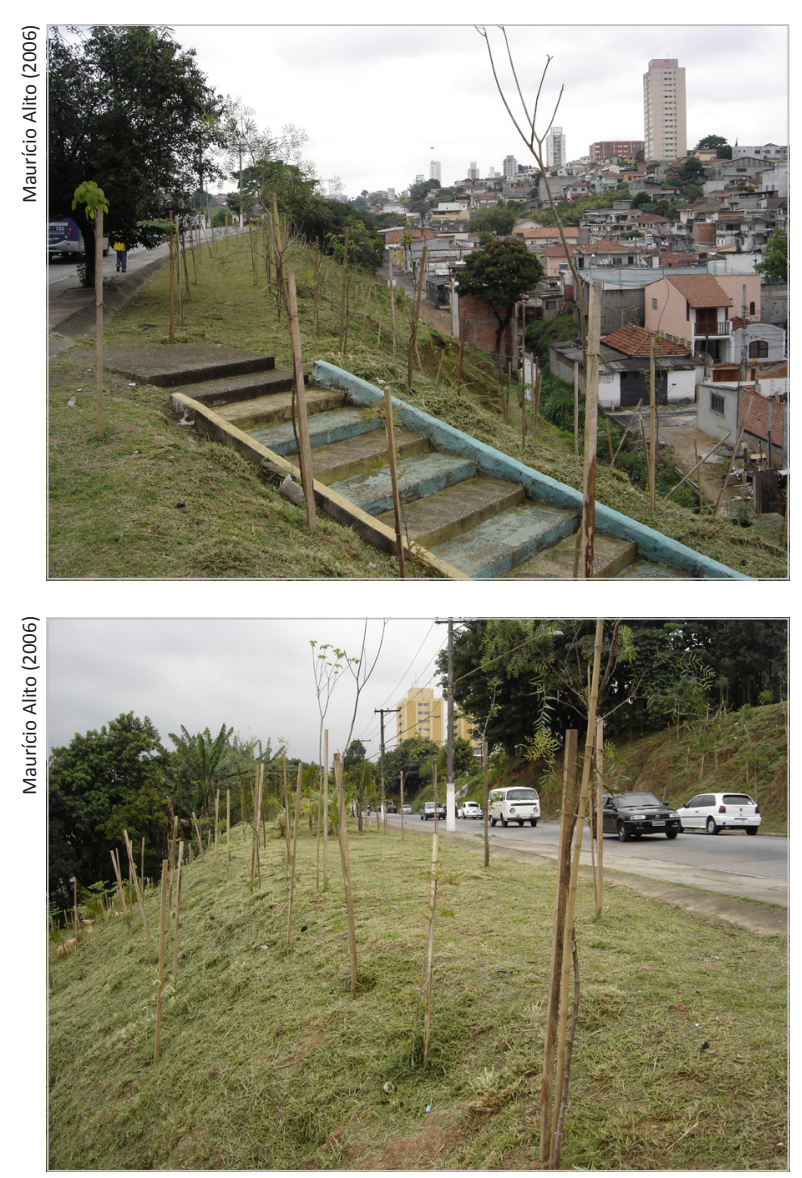

Plantio aleatório de mudas forma um verdadeiro "paliteiro" em talude no bairro de Tucuruvi.

59. MASCARO, L; MASCARÓ, J. Vegetação urbana. Porto Alegre: EDELBRA, 2002.

60. A Conferência das Nações Unidas sobre o Meio Humano, realizada em Estocolmo em 1972, é considerada um marco inicial para o aumento da conscientização ecológica no planeta.
As situações mais intrigantes, no entanto, são aquelas nas quais a estética, a funcionalidade e a qualidade ambiental são ignoradas em função do mero cumprimento de formalidades burocráticas. Variados são os exemplos nos quais a arborização urbana é reduzida ao ato de preencher determinada área com a máxima quantidade de árvores possíveis, de modo a cumprir obrigações solicitadas pela legislação ambiental.

Diversos são os exemplos de plantio realizado de forma completamente aleatória, principalmente em espaços livres públicos residuais, como terrenos de grande declividade, rotatórias e alças de acesso a vias. Essas ações são, paradoxalmente, incoerentes às necessidades ambientais do local onde são realizadas, pois não se baseiam na demanda efetiva existente. $\mathrm{O}$ uso inadequado da arborização pode atuar mais como problema do que auxílio à melhoria da qualidade de vida urbana.

Tais equívocos ocorrem devido ao não entendimento adequado dos papéis desempenhados pela arborização urbana e da integração necessária entre eles.

\section{Papel ambiental}

O uso de vegetação arbórea em áreas urbanas traz benefícios ambientais relevantes, sobretudo em regiões tropicais, onde proporcionam micro-climas mais amenos devido ao sombreamento proporcionado pelas copas. Além disso, contribuem para a retenção de partículas poluidoras, por meio de suas folhas; criam condições de sobrevivência para uma parte da avifauna que tem sido sistematicamente expulsa das áreas urbanizadas; ajudam na estabilização de terrenos com declividades acentuadas; auxiliam a drenagem de águas pluviais (nos casos de plantios em áreas permeáveis mais extensas) entre muitos outros benefícios ${ }^{59}$.

A valorização cada vez maior na mídia das qualidades ambientais propiciadas pela arborização urbana tem ocorrido em parte devido à gradativa conscientização da população a respeito das questões ambientais, sobretudo a partir da década de $1970^{60}$. Tal linha de pensamento tem auxiliado na preservação ambiental, mas ao mesmo tempo contribui para alimentar a idéia de que qualquer tipo de arborização é capaz de trazer efeitos positivos para áreas urbanizadas. 
E também pode levar ao raciocínio de que a arborização, por si só, é suficiente para melhorar a qualidade de vida da população. São recorrentes as posturas permeadas por uma visão romantizada ${ }^{61}$ da Natureza, na qual esta aparece como elemento independente das ações antrópicas. Segundo este princípio, imagina-se viável a existência de áreas dentro da cidade que funcionem de maneira autônoma à presença humana, como se fossem "oásis urbanos" nos quais se podem contrapor ambientes naturais e construídos.

Os apriorismos anteriormente citados são freqüentemente defendidos não só pela população leiga, como também por diversos profissionais detentores de graus mais elevados de conhecimento técnico sobre o assunto. $\mathrm{O}$ próprio poder público reflete esse tipo de pensamento:

Os organismos governamentais e a própria legislação vigente [...] entendem que o ambiente deve ser tratado como um éden estático e equilibrado a ser preservado e defendido de agressões e intervenções humanas que, segundo esse entendimento, descaracterizam sua forma e perturbam sua harmonia. 62

A visão da urbanização contraposta a um meio ambiente "natural" é simplista, se considerarmos o fato de que uma grande parte da vegetação existente nas cidades não é mais obra da "Natureza", mas sim o fruto da própria intervenção humana ${ }^{63}$. No caso específico de São Paulo, vale citar que:

[...] com a expansão da cultura cafeeira, a maior parte da cobertura florestal foi devastada. [...] Entretanto, em locais com menores densidades demográficas e difícil acesso, o abandono do cultivo propiciou o estabelecimento de vegetação natural secundária, que hoje constitui a maioria da cobertura florestal existente. ${ }^{64}$

Prega-se uma visão mais "ambiental" para a cidade, mas esquece-se que por ambiente entende-se o local que traga "[...] possibilidades de vida e sobrevida de todos os seres vivos e das comunidades na paisagem existente [.... ${ }^{\prime 65}$, incluso nesta definição a vida humana. Caso estas condições não sejam atendidas adequadamente para a população humana da
61. "[...] o ambiente natural tem ao longo da história (de uma forma não-linear) impactado fortemente na imaginação humana, sendo-Ihe atribuída avaliações positivas e associações sobre o que poderia ser o meio ideal." LIMA, Catharina Pinheiro Cordeiro dos Santos. A natureza na cidade, a natureza da cidade. Tese de Doutorado. São Paulo: FAUUSP, 1997. p. 167

62. LEITE, Maria Ângela Faggin Pereira. Destruição ou Desconstrução? Questões da paisagem e tendências de regionalização. São Paulo, Hucitec, 2006. p. 92

63. "Poucas são as paisagens as quais não têm a intervenção do homem, mesmo que se apresentem com elementos da base natural da paisagem. A forma e a representação da intervenção são variadas, porém praticamente todas são criação do homem" MAGNOLI, M. M. Espaço Livre - objeto de trabalho. In: Paisagem Ambiente: ensaios. n.21 São Paulo p. 178. 2006

64. SÃO PAULO (Cidade), Secretaria Municipal do Verde e Meio Ambiente. Atlas Ambiental Municipal do Município de São Paulo. São Paulo: SVMA, 2002 p. 14

65. MACEDO, Silvio Soares - Quadro do paisagismo no Brasil. São Paulo: FAUUSP, 2000, p. 13 
66. MACEDO, Silvio Soares - Quadro do paisagismo no Brasil. São Paulo: FAUUSP, 2000. P. 13

67. Cf. ANDRADE, Rubens de. “Arborização: as práticas e os processos na formação da paisagem no Brasil." In Arborização: ensaios historiográficos. Rio de Janeiro: EBA/UFRJ, 2004. cidade, estaremos diante de uma incoerência com essa visão "ambiental". A vida urbana e as comodidades por ela possibilitadas neste início de século seriam inviáveis caso as cidades fossem "oásis" dominados por florestas.

\section{Beleza é Fundamental?}

A referência para diversas idéias que a população tem acerca da arborização urbana não provém apenas da maior conscientização ecológica. Ela também tem origem em ideários antigos e atualmente cristalizados no imaginário da população.

Aquilo que por muitos é entendido como "natureza", constitui um desejo humano de ordenação lógica e a arbitrariedade de suas preferências estéticas, que variam de época para época. Macedo define como critério estético aquele "[...] que apresenta valores com características puramente sociais, atribuída pelas comunidades humanas a algum lugar, em algum momento do tempo"

O processo histórico de inserção da arborização urbana no Brasil mostra que a estética exerceu importante influência no imaginário da população, estando associada à idéia de embelezamento das cidades.

Uma parte do modo atual de pensar a vegetação no ambiente urbano remonta conceitos introduzidos no país durante o século XIX, com origem principalmente européia. São visões romantizadas da arborização, na qual esta é encarada como um retorno da "natureza" à cidade, em uma visão idealizada do campo. $\mathrm{O}$ conceito de cidade jardim introduzido por Ebenezer Howard na Inglaterra e o arranjo naturalista dos parques ingleses do séc. XIX são referenciais de larga influência.

Ao mesmo tempo, a criação de grandes massas arbóreas urbanas é utilizada como elemento de identificação da elite brasileira com os referenciais europeus então em voga, tais como os grandes parques públicos e bulevares ${ }^{67}$. As espécies utilizadas buscavam estabelecer, ao menos formalmente, uma relação com a realidade européia, afastando-se das condicionantes físicas e culturais do Brasil. 
Independentemente dos gostos e modismos de cada época, a arborização urbana atua como elemento estético importante na paisagem urbana, contrapondo-se à aridez das massas construídas e conferindo equilíbrio e conforto visual ao observador. Atuam também como importantes referenciais urbanos em meio a conjuntos edificados muitas vezes homogêneos.

Além disso, a relação que as árvores estabelecem com o entorno permite um controle de escala por parte do pedestre, atuando como elemento de transição entre as vias e as edificações urbanas.

\section{Forma e função}

O papel funcional da arborização diz respeito à sua inserção nos espaços livres urbanos. Segundo Macedo, critério funcional é aquele "que avalia o grau de eficiência do lugar no tocante ao funcionamento da sociedade humana" ${ }^{68}$. Nesses casos, portanto, o papel da vegetação arbórea relaciona-se com o suporte a atividades sociais recreativas e de convívio. O principal papel desempenhado pelas árvores nesse contexto é a configuração dos espaços. Ou seja, o plantio de árvores em espaços livres urbanos deve ser entendido sob o ponto de vista das relações espaciais que ele estabelece com o entorno.

As massas criadas pelas copas atuam na configuração de ambientes distintos dentro do espaço livre e o balizamento propiciado pelos troncos (ou fustes, no caso das palmeiras) auxilia na orientação das pessoas que por ele transitam.

Sob a ótica da configuração espacial, a arborização urbana pode gerar três situações distintas:

- Maciços arbóreos. Extensões contínuas de arborização, tais como bosques.

- Arborização Linear. Corresponde aos casos de arborização viária, tais como alamedas; ou áreas ciliares, tais como parques lineares urbanos.

- Plantio isolado. Intervenção pontual, na qual as árvores são colocadas em quantidades pequenas e de forma esparsa.
68. MACEDO, Silvio Soares - Quadro do paisagismo no Brasil. São Paulo: FAUUSP, 2000. P. 13 

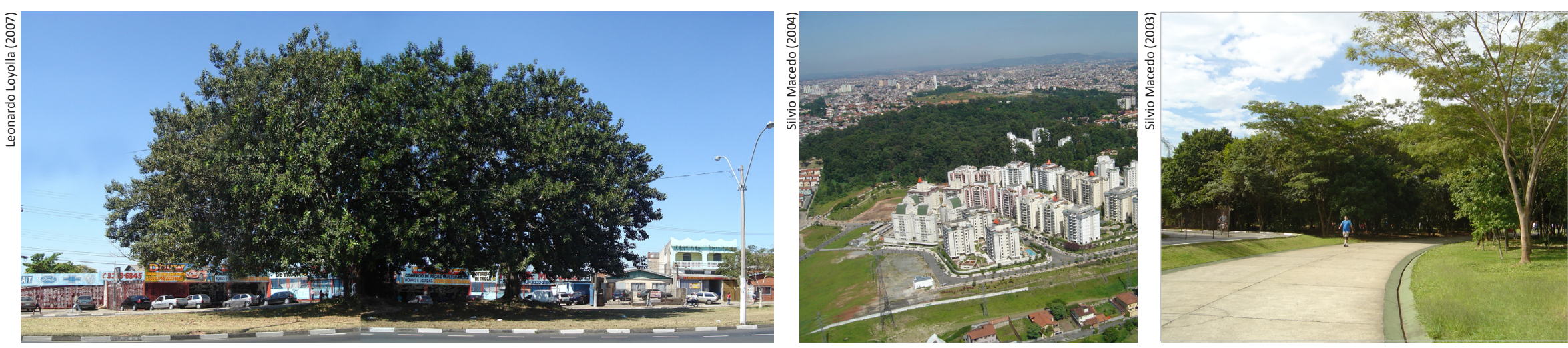

Arborização atuando como elemento de configuração do espaço urbano em três situações distintas. Da esquerd para a direita: 1) Devido ao seu grande porte, dois exemplares de Ficus elastica são elementos focais deste trecho da Av. Ruy Rodrigues, Campinas - SP. 2) Bosque contínuo formado pelo Parque Colinas de São Francisco (Subprefeitura do Butantã) contrapõe-se ao entorno construído. 3) Bosque visto da escala do pedestre no Parque Villa Lobos, São Paulo - SP.

\section{Cf. nota 09}

70. “[...] o potencial do sistema viário enquanto espaço livre formado pelo conjunto de ruas e avenidas pode representar a maior área de implantação da cidade [d São Paulo]. Comparativamente, o sistema viário, com seus $180 \mathrm{~km}$, tem área superior às áreas dos parques, praças, canteiros e areas verdes na cidade, que juntos, somam $57,2 \mathrm{~km}$. JÚNIOR, Roberto Vignola. A arborização de vias públicas e a paisagem urbana. Caso da cidade de São Paulo. Dissertação de Mestrado. São Paulo. FAUUSP, 2005. p. 120
$\mathrm{Na}$ maioria das vezes, apenas as duas primeiras situações citadas contribuem efetivamente para a cidade, seja pelo seu papel funcional, estético ou ambiental.

Massas arbóreas extensas potencializam os atributos ambientais da vegetação tais como suporte para a avifauna, estabilidade do solo, criação de áreas permeáveis e atenuação do efeito de borda ${ }^{69}$.

A criação de corredores de arborização auxilia na movimentação da avifauna pelas massas arbóreas da cidade, além de atender a áreas urbanas mais extensas ${ }^{70}$ do que as intervenções fragmentadas.

Além disso,tanto os maciços quanto os corredores arbóreos formam conjuntos esteticamente expressivos, contrapondo-se às extensas massas construídas presentes nas grandes cidades. E auxiliam na configuração de espaços livres públicos, conferindo sombreamento adequado e contribuindo para torná-los referenciais urbanos significativos.

As intervenções pontuais, por sua vez, trazem poucos benefícios para áreas urbanas, pois na maioria das vezes não possuem peso funcional, estético ou ambiental tão significativo quanto os maciços arbóreos. Além disso, poucas são as situações nas quais o plantio esparso atua efetivamente na configuração de espaços distintos.

Naturalmente, tal ponto de vista não significa que as árvores pontuais existentes nas cidades devam ser desprezadas. Há casos de plantio de indivíduos isolados com grande 
porte ou formas expressivas, que passam a configurar o espaço do entorno, tais como o Ficus elastica.

Nos três tipos de arborização citados, podem-se empregar seqüências homogêneas ou heterogêneas de espécies. O plantio heterogêneo, desde que realizado adequadamente, contribui para conferir movimentação visual ao conjunto de árvores, seja pelas diferenças de cores das folhas e florações ou pelas diferenças volumétricas e de porte. Também beneficia questões ambientais, contribuindo para o enriquecimento de ecossistemas. $\mathrm{O}$ uso de seqüências homogêneas, embora possa enfatizar um efeito desejado, também traz conseqüências ambientais negativas, tais como a maior suscetibilidade ao ataque de pragas. ${ }^{71}$ Além disso, a utilização de um número restrito de espécies no Brasil representa uma ironia frente à grande biodiversidade vegetal que o país possui.

O imaginário da população costuma associar diretamente o conceito de espaços livres à existência de vegetação, algo evidenciado pelo uso freqüente da expressão "áreas verdes" para designá-los. A vegetação não constitui, no entanto, parte essencial do espaço livre ${ }^{72}$. A essência do conceito refere-se à ausência de edificações e não à existência de arborização.

\section{Consequências}

Quando se ouve a afirmação de que a cidade precisa de mais "áreas verdes", no caso significando o plantio de mais árvores ou a introdução de novas áreas arborizadas, na maioria dos casos não se leva em consideração o custo de sua presença no meio urbano.

A idealização do papel desempenhado pelo plantio de árvores na cidade leva muitos a esquecerem de que este constitui um tipo de intervenção marcadamente humana.

Todo o processo de inserção e seleção para arborizar uma cidade envolve um extremo grau de dependência ao controle humano ${ }^{73}$. As árvores escolhidas para o meio-ambiente urbano devem corresponder a uma série de requisitos rigorosos que as tornam praticamente "peças industrializadas" 74 . Apesar disso, fatores funcionais importantes como variabilidade genética, porte adequado à fiação elétrica e ao plantio em calçadas e utilização de espécies
71. A respeito do potencial destrutivo da ação de pragas arbóreas, vale citar o seguinte exemplo: "O levantamento das espécies arbóreas no meio urbano da cidade de Jaboticabal, SP, realizado em 1987 (GRAZIANO et al., 1987), mostrou que 43\% do número total de plantas da arborização de ruas era representada pela espécie Nectandra saligna (canelinha). Em 1992 foi relatada et al., 1992) nesta espécie. Em decorrência deste problema, et al., 1992) nesta especie. Em decorrência deste problema, em 2002, este valor passou para 7,88\% (SILVA FILHO, 2002)" acadêmico. Jaboticabal: UNESP/FCAV/FUNEP, 2002. p.10-11

72. “O projeto de arquitetura paisagística sempre está aplicado a um único objeto, o espaço livre - seja ele uma rua, um pátio, um jardim, um parque - e não exige necessariamente vegetação para a sua concretização [...]".MACEDO, Silvio Soares - Quadro do paisagismo no Brasil. São Paulo: FAUUSP, 2000. p.15

73. SPIRN, Anne Whiston. $O$ jardim de granito: a natureza no desenho da cidade. São Paulo: EDUSP, 1995

74. JÚNIOR, Roberto Vignola. A arborização de vias públicas e a paisagem urbana: caso da cidade de São Paulo. Dissertação de Mestrado. São Paulo: FAUUSP, 2005. 
75. SPIRN Anne Whiston O jardim de granito: a natureza no desenho da cidade São Paulo, EDUSP, 1995

76. “Em 2004, contratado pela prefeitura, o IPT conduziu uma pesquisa em 7050 árvores de sete regiões da capital (Alto de Pinheiros, Pacaembu-Sumaré, Paraíso, Alto da Lapa, Alto da Boa Vista, Cerqueira César e Vila Nova Conceição). Concluiu que 18\% apresentavam risco de queda. Nem a Secretaria do Verde e do Meio Ambiente nem a das Subprefeituras sabem informar se, de fato, alguma providência foi tomada". CENTOFANTI, M. Temporada de quedas: Chuva forte derruba 209 árvores em um dia. Cupins e descuido agravam o problema. Revista Veja São Paulo. 23.11.2006

77. De acordo com o Programa São Paulo Protege, realizado pela prefeitura do município, a Subprefeitura da Lapa estima que "[...] em 2002, aproximadamente 133 indivíduos arbóreos caíram nessa região." Prefeitura do Município de São Paulo. Secretaria do Verde e do Meio Ambiente. IPT. GEO cidade de São Paulo: panorama do meio ambiente urbano. Brasília: PNUMA, 2004. p.109 condizentes com o clima, solo e fauna brasileiros têm sido freqüentemente sacrificados em nome de modismos.

O desrespeito a um espaçamento mínimo e a um porte máximo para plantio causa disputas desnecessárias das árvores por espaço. A desconsideração das redes de infra-estrutura que circundam a árvore a ser plantada pode gerar sérios conflitos com elementos como a fiação elétrica, tubulação e piso da calçada, a exemplo dos freqüentes casos encontrados facilmente na cidade de São Paulo. As calçadas de cidades como São Paulo, por sinal, não foram concebidas, em sua maioria, com espaço suficiente para o plantio arbóreo.

Embora existam algumas (louváveis) iniciativas do poder público para programas de arborização urbana, costuma-se ignorar o fato de que os indivíduos plantados hoje necessitarão de manutenção adequada e reposição dentro de um determinado tempo Também deve ser prevista a reposição das árvores que hoje em dia já apresentam comprometimento do estado fitossanitário.

Outro fator fundamental a ser considerado é o custo para manter adequadamente a vegetação implantada. O simples plantio, desconsiderando a necessidade de uma constante e dispendiosa manutenção, pode ocasionar uma série de problemas que em geral não são levados em consideração em uma primeira análise ${ }^{75}$. O plantio de árvores em áreas urbanas precisa estar vinculado a programas de manutenção adequados.

Em 2008 a Secretaria do Verde e Meio Ambiente da cidade de São Paulo sequer consegue mensurar adequadamente a quantidade de árvores que se encontram comprometidas ${ }^{76}$. Exemplo disso são as constantes quedas de árvores que ocorrem durante o período das chuvas mais fortes ${ }^{77}$.

Plantar uma árvore na porta de casa também significa a limpeza mais constante de telhados e sistemas de drenagem devido à queda natural de folhas, flores e frutos. Pode também atrair além de aves e pequenos vertebrados, uma fauna indesejável. Estes são custos aos quais considerável parcela da população ainda não se mostra disposta a arcar. 
Não são poucos os casos nos quais, ao se deparar com a possibilidade de arborizar um espaço livre, a população local argumente que a existência de árvores diminui a segurança e podem aumentar problemas com narcotráfico na vizinhança, por criar recantos excessivamente sombreados. Tal problema é algo que, na maioria das vezes, não é culpa da arborização, mas sim de questões mais abrangentes - como a violência urbana - ou mais pontuais, como um sistema de iluminação pública mal-elaborado ${ }^{78}$.

Mudar esse modo de pensar depende do esclarecimento e sensibilização a respeito da importância do plantio de árvores. Arborizar prescinde de um trabalho continuo com a comunidade por meio da educação ambiental, de modo que esta entenda como manter vivo esse recurso. 

CAPÍTULO III

Compensações

Ambientais em

São Paulo 



\section{Preparando o terreno: a inserção das compensações ambientais na legislação brasileira e paulista}

\section{Legislação Federal}

Como foi visto anteriormente, a aplicação das compensações ambientais no Brasil vinculase ao processo de licenciamento. $\mathrm{O}$ estabelecimento desse vínculo ocorreu de forma gradativa.

A figura do Licenciamento Ambiental surge pela primeira vez no Brasil com a Lei Federal 6.938/81, inserido como um dos instrumentos da Política Nacional do Meio Ambiente. A compensação ambiental aparece implícita, ainda de forma genérica, no conceito de responsabilidade objetiva, onde se afirma que o poluidor é "obrigado, independentemente da existência de culpa, a indenizar ou reparar os danos causados ao meio ambiente e a terceiros, afetados por sua atividade." 79

Em 1986, a Resolução 001 do Conselho Nacional do Meio Ambiente (CONAMA) consolida o uso do Estudo de Impacto Ambiental (EIA) como principal ferramenta dos processos de licenciamento. As compensações aparecem novamente de forma implícita, quando o artigo $6^{\circ}$ afirma que o EIA deve conter a "definição das medidas mitigadoras dos impactos negativos." 80

Embora se abra espaço para o estabelecimento de medidas mitigadoras, as compensações ambientais arbóreas só serão previstas a partir da Resolução CONAMA 010 /87, sob a forma de "reparação aos danos ambientais causados pela destruição de florestas e outros ecossistemas" 81 .Estabelece-se como medida compensatória para esses casos, a "implantação de uma estação ecológica pela entidade ou empresa responsável pelo empreendimento, preferencialmente junto à área." 82

O documento determina que o valor da compensação obedeça a um (polêmico) patamar mínimo de $0,5 \%$ do custo total da implantação do empreendimento, sendo proporcional ao dano a ser ressarcido e determinado pelo órgão licenciador ambiental.

79. Lei Federal 6.938/1981. Art.14 § 1은

80. Resolução CONAMA 001 /1986 Art. 6o

81. Resolução CONAMA $010 / 1987$ Art. 1 음

82. Ibidem 
Segundo Geluda e Young, estabelecer tal patamar é problemático:

[ao] interpretar que o valor da compensação deva ser calculado em função do valor do empreendimento, tal proposta penalizaria os projetos que mais gastassem em controle ambiental e beneficiaria aqueles nos quais os custos do investimento sejam os menores possíveis [...]. ${ }^{83}$

Nesse sentido, os autores consideram que:

[...] a compensação ambiental deveria ser calculada de acordo com o dano causado, utilizando o instrumento de valoração ambiental, e não sobre o custo do investimento. Até porque o que deve ser compensado é o dano. Essa metodologia seria mais justa com os empreendedores que já incluem em seus custos as medidas de prevenção. ${ }^{84}$

Os autores também criticam as distorções conceituais se fazem presentes na aplicação da legislação de compensação ambiental pelo Poder Público brasileiro. O modo como as compensações são direcionadas em âmbito federal permite interpretar que estas são entendidas como um recurso orçamentário para o Estado ${ }^{85}$. Tal postura contribui para consolidar a idéia de que quaisquer recursos naturais são passíveis de troca - neste caso, por recursos orçamentários - o que constitui uma grave falha conceitual.

Nove anos depois, a Resolução CONAMA 002/1996 torna preferencial (e não mais obrigatória) a implantação compensatória de estações ecológicas. Flexibiliza-se, desse modo, a aplicação de recursos nas unidades de conservação nacionais.

83. GELUDA, L. ; YOUNG, C. E. F. . Financiando o Éden: Potencial econômico e limitações da compensação ambiental prevista na Lei do Sistema Nacional de Unidades de Conservação da Natureza. In: IV Congresso Brasileiro de Unidades de Natureza, 2004. v. 1. p.649

84. Ibidem. p. 649

85. GELUDA, L.; YOUNG, C. E. F. “Financiando o Éden: Potencial econômico e limitações da compensação ambiental prevista na Lei do Sistema Nacional de Unidades de Conservação da Natureza." In: IV Congresso Brasileiro de Unidades de Conservação, 2004, Curitiba. IV Congresso Brasileiro de Unidades de Conservação. Curitiba: Fundação O Boticário de Proteção à Natureza, 2004 . 1. 6. 641-651.

86. SILVA FILHO, Carlos Alberto da. Proteção e fomento da vegetação no Município de São Paulo: possibilidades, alcance e conflitos. Tese de doutorado. São Paulo, FAUUSP, 2005. p.73

Em 1998, a Lei Federal 9.605, também conhecida como Lei de Crimes Ambientais, potencializou a aplicação de compensações ambientais no país, pois “[...] transformou em crime nove das quatorze condutas e atividades lesivas às florestas e demais formas de vegetação $[. .] "$.86 . Ao estabelecer penalidades mais pesadas para os danos ambientais, a lei acelerou o aparelhamento das esferas estaduais e municipais para aplicação da legislação. Nesse mesmo ano, a compensação ambiental começa a ser aplicada no Município de São Paulo. 
Além disso, a Lei de Crimes Ambientais estabelece ${ }^{87}$ a utilização do Termo de Ajustamento de Conduta, mecanismo de compensação aplicado nos casos de reparação por danos causados ao meio ambiente.

Em 2000, a Lei 9.985 implanta o Sistema Nacional de Unidades de Conservação (SNUC). Ao mesmo tempo, por meio do seu artigo n³6, consolida o conteúdo presente nas resoluções CONAMA 001/86 e 010/87. Nele se estabelece que, como medida compensatória para os casos de significativo impacto ambiental, "o empreendedor é obrigado a apoiar a implantação e manutenção de unidade de conservação do Grupo de Proteção Integral [...]" 88 . Tal princípio, regulamentado pelo Decreto Federal 4.340/2002, torna obrigatória a aplicação de compensações ambientais no país.

A Medida Provisória 2166-67/2001, que acresce dispositivos ao Código Florestal ${ }^{89}$, também faz menção às compensações ambientais ao afirmar que "o órgão ambiental competente indicará, previamente à autorização de supressão de vegetação em área de proteção permanente, as medidas mitigadoras e compensatórias que deverão ser adotadas pelo empreendedor. ${ }^{\prime 9}$.

Três anos depois, a Portaria 07/2004 do IBAMA (Instituto Brasileiro do Meio Ambiente e dos Recursos Naturais Renováveis) institui uma Câmara de Compensação Ambiental, responsável pela análise das medidas compensatórias em âmbito federal. Abre-se assim, precedente para a abertura de câmaras de compensação na esfera estadual (criada em São Paulo nesse mesmo ano) e municipal (criada um ano depois na cidade de São Paulo). Em complementação à criação da câmara, a Instrução Normativa IBAMA 47/2004 estabelece os procedimentos para a gestão da compensação ambiental.
87. Por meio da Medida Provisória 1710/98.

88. Lei $9.985 / 2000$. Art. 36

89. Lei Federal $4771 / 1965$

90. Medida Provisória 2166-67/2001. Art 4ㅇ․ §4ํำ 


\section{Legislação Estadual}

No Estado de São Paulo, a aplicação das compensações ambientais pela retirada de árvores é responsabilidade do Departamento Estadual de Proteção aos Recursos Naturais (DEPRN), órgão vinculado à Secretaria do Meio Ambiente (SMA).

Nos casos de supressão arbórea em sua jurisdição, o DEPRN trabalha com duas situações distintas: atividades extrativistas e degradação ambiental. A primeira delas envolve o consumo de matéria prima florestal e possui critérios específicos de avaliação que não constituem o foco desta pesquisa.

Os casos de degradação ambiental subdividem-se em duas hipóteses: a retirada de árvores autorizada pelo DEPRN (compensação) e a reparação de um dano já causado (ajustamento de conduta).

A autorização de cortes de árvore e a definição da quantia compensatória são partes integrantes do processo de licenciamento ambiental, sendo expressas em um documento denominado Termo de Compromisso de Compensação Ambiental (TCCA).

Os parâmetros para aplicação das compensações ambientais arbóreas no Estado de São Paulo estão definidos na Resolução 16 da Secretaria do Meio Ambiente, emitida em 2001. Em consonância com a Lei Federal 9.985/2000, o documento estabelece que o valor da compensação não seja inferior a $0,5 \%$ do custo total do empreendimento. Além disso, estipula o prazo máximo para cumprimento do termo, atrelando-o à emissão da licença ambiental.

Em 2004 é criada a Câmara de Compensação Ambiental, responsável pela avaliação dos casos de âmbito estadual. 


\section{O Departamento de Parques e Áreas Verdes de São Paulo (DEPAVE)}

O entendimento da trajetória do DEPAVE mostra-se importante para a contextualização das compensações ambientais, uma vez que foi responsabilidade desse departamento a viabilização e aplicação do mecanismo na cidade de São Paulo.

O DEPAVE, com atribuições semelhantes às que se mantiveram durante sua história, tem origem no Departamento de Parques e Jardins do Município, criado em $1968^{91}$ e mais conhecido na época como Parque. Antes da criação desse departamento, as atribuições se restringiam à execução do plantio e à manutenção das áreas verdes, sendo deixadas a encargo de engenheiros agrônomos e jardineiros. A partir desse momento, as atividades projetuais - que antes, quando ocorriam, eram delegadas ao departamento de urbanismo - passam a ser de sua responsabilidade. O perfil dos profissionais envolvidos também foi alterado, sendo que:

[...] passou a contar com uma equipe pluridisciplinar, composta de arquitetos, engenheiros agrônomos, engenheiros civis, além de agrimensores, projetistas e orçamentistas, com a atribuição de programar a implantação e elaborar integralmente os projetos de paisagismo das áreas verdes municipais. $^{92}$

Somente em 1976 o departamento passou a se chamar DEPAVE ${ }^{93}$. Juntamente a essa mudança, uma norma interna dividiu a responsabilidade pelos projetos paisagísticos conforme seu porte: áreas superiores a $5000 \mathrm{~m}^{2}$ eram direcionadas ao departamento, enquanto projetos com porte inferior a este eram realizados pelas Administrações Regionais ${ }^{94}$.

Nessa mesma época, em sintonia com o contexto de reestruturação do departamento, é solicitado pela Secretaria de Serviços Municipais um Plano de Áreas Verdes de Recreação para o Município de São Paulo. O trabalho, realizado entre os anos de 1967 e 1969 por equipe externa à Divisão de Parques e Jardins, foi coordenado pelas arquiteta-paisagistas Rosa Grena Kliass e Miranda Martinelli Magnoli ${ }^{95}$. O documento é (e permanece, ao menos até o ano de 2008) pioneiro ao dimensionar a demanda, estabelecer critérios para
91. Lei Municipal n 7.108 de 10 de janeiro de 1968

92. BARTALINI, Vladimir. Parques públicos municipais de São Paulo. Tese de Doutorado. São Paulo: FAUUSP, 1999. p. 148

93. Lei Municipal n 8.491/76

94. Atualmente denominadas Subprefeituras. Essa divisão de responsabilidades permaneceu, e se mantém até o momento (2008)

95. KLIASS, R. G. \& MAGNOLI, M. M.. Áreas Verdes e Recreação. Município de São Paulo. São Paulo: PMSP, 1967-1969. 


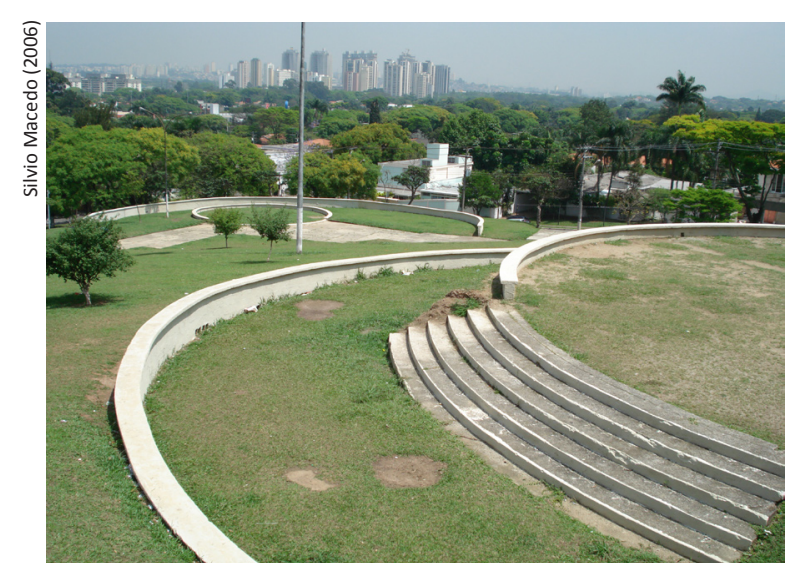

Praça Cel. Custódio Fernandes Pinheiro (Praça do Pôr -do-Sol). Projeto realizado pela Arq. Miranda Magnoli de 1967, época do Plano de Áreas Verdes do município de São Paulo.

96. BARTALINI, Vladimir. Parques públicos municipais de São Paulo. Tese de Doutorado. São Paulo: FAUUSP, 1999. p. 171

97. Ibidem, p. 150

98. Ibidem, p.178

99. Cf. STESCHENKO, Wolfgang Sergio. Contribuição ao estudo e ao processo de produção da praça pública paulistana - o

Departamento de Parques de Parques e Áreas Verdes de São Paulo de 1967 a 1979. Dissertação de Mestrado. São Paulo, FAUUSP, 2001

100. MACEDO, Silvio Soares. Quadro do paisagismo no Brasil. São Paulo: FAUUSP, 1999. p. 55-100 implantação e criar uma escala hierárquica para os espaços livres no Município de São Paulo. Foram também realizados mais de quarenta projetos paisagísticos detalhados ${ }^{96}$. Embora tenha quantificado com maior precisão a carência de espaços livres daquela época, além de ter estabelecido importantes parâmetros e referências; apenas alguns projetos paisagísticos previstos no plano foram efetivamente implantados.

Nos vinte e cinco anos seguintes à sua criação, a estrutura de funcionamento e a equipe do DEPAVE permaneceriam sem grandes alterações:

De 1968, ano de criação do Departamento de Parques e Jardins, a 1993, quando se tornou um Departamento da Secretaria do Verde e do Meio Ambiente [...] sua composição e suas funções não se alteraram essencialmente, apesar das trocas de nome das Secretarias a que esteve subordinado, firmando-se como órgão produtor e executor de projetos e administrador de áreas verdes públicas municipais ${ }^{97}$.

O período mais fértil de produção e execução da equipe do DEPAVE ocorreu entre os

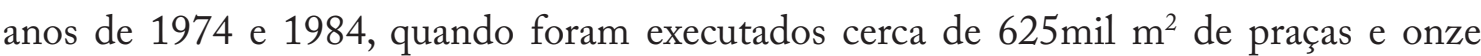
parques públicos, que totalizaram quase $12.000 .000 \mathrm{~m}^{2}$ de área ${ }^{98}$. Excetuando-se as praças feitas pela Companhia do Metropolitano de São Paulo e alguns projetos da EMURB, poucos foram os projetos paisagísticos públicos implantados nessa época cuja autoria não fosse da equipe do departamento ${ }^{99}$.

As características dos projetos realizados pela equipe do DEPAVE estavam em sintonia com várias diretrizes projetuais modernistas ${ }^{100}$. Destacam-se entre elas: a valorização do emprego de vegetação nativa - em sua maioria de porte arbóreo; a utilização, sobretudo nos projetos de menor porte, de soluções formais de marcada geometria, com influência dos projetos paisagísticos norte-americanos das décadas de 1940-50 (e dos projetos de Kliass e Magnoli para o Plano de Áreas Verdes) e a delimitação clara de funções de lazer ativo, tais como playgrounds e quadras esportivas.

As limitações de recurso e prazos também condicionaram bastante a forma de projetar do departamento: 
[...] com orçamentos limitados, prazos exíguos para confeccionar os projetos, equipe de projeto pouco diversificada - composta basicamente por arquitetos e agrônomos - e com relações frágeis e esporádicas com outros órgãos da administração municipal, havia poucas condições favoráveis para projetos inovadores dentro do DEPAVE ${ }^{101}$

A criação em 1993 de uma Secretaria Municipal específica para questões de meio ambiente $^{102}$ traria as primeiras mudanças substanciais do DEPAVE em muitos anos de sua existência. Com essa alteração, o departamento passa a ser o mais importante dos três vinculados à recém criada Secretaria Municipal do Verde e Meio Ambiente ${ }^{103}$

Além disso, o DEPAVE passa a ter 6 divisões internas. Uma delas é responsável pela concepção e viabilização de projetos paisagísticos (DEPAVE 1); outras duas são responsáveis por questões relacionadas ao manejo e manutenção da flora (produção de mudas e manejo e conservação). As três restantes correspondem a questões relativas à fauna, tecnologia e (curiosamente) planetários.

A inauguração dos parques Cidade de Toronto ${ }^{104}$ em 1992 e Burle Marx ${ }^{105}$ em 1993 estabelecem interação do DEPAVE com elementos externos à sua equipe · Esses foram os primeiros projetos de parque desde 1968 cuja concepção e manutenção não foram realizados pelo departamento, sendo direcionados à iniciativa privada. Segundo Bartalini, esses projetos evidenciam os prenúncios de novos tempos no DEPAVE, caracterizados por maiores interações com a iniciativa privada para viabilização de espaços livres públicos e pela redução das atribuições projetuais do departamento ${ }^{106}$.

Devido às constantes restrições orçamentárias, ao número insuficiente de técnicos e ao contexto de aumento das participações da iniciativa privada, a produção de projetos do DEPAVE na década de 1990 declinou, se comparada a períodos anteriores. As atribuições do departamento passaram a estar muito mais ligadas à manutenção e fiscalização dos espaços livres existentes e ao processo de licenciamento de novos empreendimentos no município.

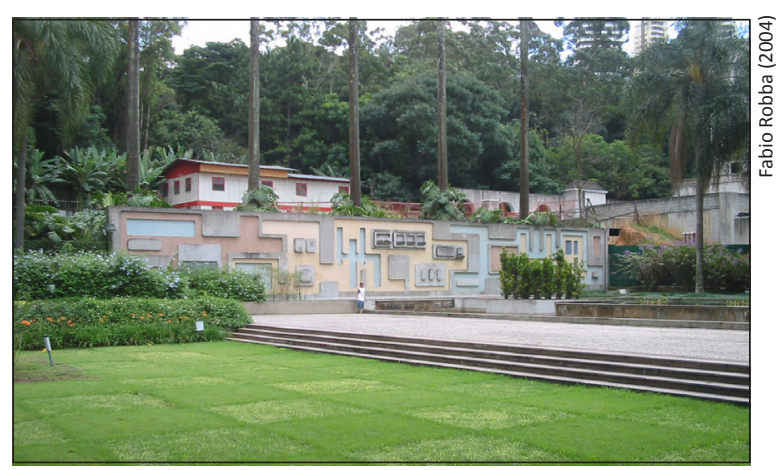

Parque Burle Marx.

101. BARTALINI, Vladimir. Parques públicos municipais de São Paulo. Tese de Doutorado. São Paulo: FAUUSP, 1999. p. 182 102. Criada pela Lei Municipal 11.426/1993

103. Os outros dois departamentos são o DECONT (Controle de Qualidade Ambiental) e o DEAPLA (Educação Ambiental).

104. O parque, localizado no bairro de City América, é resultado de um programa de cooperação técnica entre as prefeituras das cidades de São Paulo e Toronto (Canadá).

105."O projeto do parque Burle Marx constou, em parte, da recomposição do antigo jardim criado por Roberto Burle Marx em 1950, feita com a supervisão do escritório Burle Marx e Cia. Ltda. e, em parte da adaptação do restante do terreno para parque público, feita com a consultoria da firma KRAFPlanejamento Ambiental" BARTALINI, Op. cit. p. 150 106. BARTALINI, Op. cit. p.150 
107. As relaç̃̃es conflituosas decorrentes da aplicação das compensações ambientais em São Paulo serão aprofundadas mais à frente.

108. Nos demais projetos, como o Parque Pinheirinho D’Água, a equipe DEPAVE seria responsável por apenas uma parte, em gera o estudo preliminar ou anteprojeto. O detalhamento final ficava ao encargo de escritórios privados.
Como o departamento não sofreu mudanças significativas em seu corpo técnico ao longo de sua história, as equipes que nas décadas de 1970 e 1980 trabalharam prioritariamente com o projeto de praças e parques, tiveram de se adaptar a uma nova realidade. Em decorrência da retirada das atribuições projetuais, surgiram conflitos entre os representantes do Poder Público e da iniciativa privada ${ }^{107}$.

Em 1998, as compensações ambientais começam a ser aplicadas em São Paulo, inseridas em um contexto de terceirização de serviços. O mecanismo se torna uma fonte alternativa de captação de recursos para novos projetos, atenuando um dos maiores problemas sempre enfrentados pelo departamento.

Por outro lado, a consolidação do uso das compensações ambientais em São Paulo acentuou a redução das atribuições projetuais do departamento. Isto se deve à própria natureza do mecanismo, que delega diversas responsabilidades - tanto projetuais como de manutenção - à iniciativa privada. Como será visto mais à frente, dos projetos custeados por compensações ambientais, apenas o Parque da Vila Prudente foi inteiramente executado pela equipe do DEPAVE ${ }^{108}$.

Nos anos 2000, a responsabilidade do departamento pelos projetos paisagísticos no município declina ainda mais. O Programa Centros de Bairro - a ação quantitativamente mais relevante para produção de espaços livres em São Paulo nessa década - foi direcionado pela prefeitura à equipe da EMURB. Desejava-se que todos os espaços livres solicitados fossem concluídos até o ano de 2004, fim do mandato vigente na época. A rapidez exigida no processo de produção não se mostrava compatível com as sucessivas reduções de produção que o DEPAVE sofreu desde a década de 1990.

A partir de 2007, passa a ser viabilizada a construção dos parques lineares previstos no Plano Diretor de 2002. Vários desses novos espaços livres são custeados por compensações ambientais. A maioria dos projetos é elaborada pela equipe da Coordenadoria de Planejamento Ambiental e Ações Descentralizadas (COPLAN), diretamente vinculada à Secretaria do Verde e Meio Ambiente. Poucos ficam ao encargo do DEPAVE. 


\section{Evolução (e algumas involuções) da compensação ambiental na cidade de São Paulo}

\section{Onze anos iniciais: da reposição à compensação}

As compensações ambientais em São Paulo foram gradativamente sendo introduzidas por meio de novos dispositivos que, em seu conjunto, não só evidenciariam sua necessidade, como também abririam espaço para sua viabilização.

\section{Lei Municipal 10.365/87 e o Decreto Estadual 30.443/89: fundamentos para a compensação}

O ponto de partida para as compensações ambientais em São Paulo é o ano de 1987 - mais de dez anos antes do aparecimento oficial desse mecanismo como legislação. Nesse ano entra em vigor a Lei Municipal $10.365^{109}$. Antes dela, a proteção da vegetação em São Paulo era regulamentada, de modo precário, pelo Decreto 9.367/71. Segundo Silva Filho:

A necessidade da promulgação de uma Lei Municipal para o disciplinamento do corte e da poda da vegetação arbórea foi justificada [...] pela ineficiência da legislação vigente: o Decreto 9.367, de 03 de março de 1971, promulgado na primeira gestão como prefeito do engenheiro Paulo Salim Maluf ${ }^{110}$.

A Lei 10.365/87 define o que é considerado árvore pelo Poder Público na cidade de São Paulo, estabelecendo que vegetação arbórea é toda aquela que apresente $\mathrm{DAP}^{111}$ superior a $5 \mathrm{~cm}^{112}$. Em 2008, esta permanece sendo a definição utilizada no município.

Outro ponto relevante dessa lei foi estabelecer a necessidade de reposição das árvores retiradas em terrenos particulares, com ou sem autorização prévia do Poder Público. A reposição vegetal passou a obrigar o plantio de uma árvore para cada retirada (proporção 1:1): "As árvores suprimidas por corte ou poda que ocasione a sua morte, em áreas particulares, de forma irregular ou autorizada, deverão ser obrigatoriamente substituídas, em igual número, pelo proprietário ou possuidor [...]"113. A mesma necessidade de reposição passa a ser válida para as árvores localizadas em logradouros públicos. ${ }^{114}$
109. Regulamentada pelo Decreto Municipal 26.535/88 110. SILVA FILHO, Carlos Alberto da. Proteção e fomento da vegetação no Município de São Paulo: possibilidades, alcance conflitos. Tese de doutorado. São Paulo, FAUUSP, 2005. P.79 da árvore à altura do peito de uma pessoa adulta - adotado como $1,30 \mathrm{~m}$

112. No Brasil a definição de árvore varia de cidade para cidade. Por exemplo: a legislação de compensação ambiental arbórea de Porto Alegre em 2008 (Decreto Municipal no 15.418/2006) utiliz como critério o porte superior a $2 \mathrm{~m}$.

113. Lei Municipal 10.365/87. Art.14

114. Ibidem. Art. 15 
Vale ressaltar que o detalhamento das características da vegetação repositória - como espécie e porte - não aparece em nenhum dos dois casos citados. E embora se estabeleça que a preservação da muda plantada deva ser de responsabilidade do causador do dano ambiental, tal determinação ocorre de forma vaga, não se estipulando o prazo para esta manutenção. Tal situação fica evidenciada no seguinte trecho da lei: "Nas hipóteses previstas neste artigo (reposição da vegetação arbórea suprimida), o proprietário ou possuidor ficará responsável pela preservação das árvores novas." 115

A reposição arbórea não pode ser considerada uma forma efetiva de compensação ambiental. Sua contribuição para atenuar os danos causados pela retirada de uma árvore é rudimentar, limitando-se ao plantio de um exemplar que demorará vários anos para atingir a maturidade. Além disso, está suscetível a inúmeros fatores que podem comprometer sua consolidação futura, sobretudo em ambientes urbanos. Mas constitui um avanço em relação à inexistência de regras claras anteriores.

A proporção 1:1 estabelecida pela lei 10.365 permaneceria como referência (ao menos formal) para casos de supressão arbórea por mais dez anos. Além do estabelecimento da necessidade de reposição arbórea, diversas outras inovações foram introduzidas por essa lei, dentre as quais se destacam:

- Definição da responsabilidade de custeio da reposição arbórea a encargo do responsável pelo dano ambiental. O plantio, no entanto, seria realizado pela Administração Regional (atual Subprefeitura)

- Estabelecimento de incentivos para os proprietários que auxiliem na proteção à vegetação de preservação permanente presente em seu terreno, na forma de redução do Imposto Territorial Urbano (ITU) ${ }^{116}$. Segundo Silva Filho, esse é o único mecanismo tributário relacionado ao fomento e proteção da vegetação na cidade de São Paulo ${ }^{117}$.

- Determinação das responsabilidades da Administração Regional e do DEPAVE frente à necessidade de remoção de árvores no município. 
- Estabelecimento das condições para supressão de indivíduos arbóreos. Esta determinação das circunstâncias permitidas para corte das árvores, presente em seu artigo 11, permaneceria como referência para as todas as legislações posteriores, que ainda fazem menção a esse texto no ano de 2008.

- Listagem da documentação e procedimentos para pedidos de remoção e manejo de árvores no município.

- Direcionamento da responsabilidade pelo corte e poda de árvores a funcionários da prefeitura.

Além dos aspectos já salientados, nota-se que o texto da Lei 10.365/87 apresenta uma ligação forte com o setor da construção civil. Isto se deve ao fato desse setor ser o maior gerador de impactos à vegetação no município. Deve-se também à subordinação ainda existente naquela época da área responsável pelas questões de meio ambiente (no caso, o DEPAVE) em relação à Secretaria de Obras e Serviços (SSO). Este vínculo da área ambiental ao setor de obras (que, por sinal, ainda ocorre em diversas cidades do país) só reduziria a partir de 1993, quando se cria a Secretaria Municipal do Meio Ambiente $(\mathrm{SMMA})^{118}$.

Embora a Lei Municipal 10.365 estabelecesse as condições para supressão arbórea no município, a determinação das árvores protegidas pelo Poder Público nessa legislação fazia referência ao Código Florestal de $1965^{119}$.

Em 1989, o Decreto Estadual 30.443 passa a definir com maior precisão qual parcela da vegetação arbórea do Município de São Paulo é imune a corte. A delimitação das árvores protegidas pelo Poder Público - ou seja, do patrimônio ambiental do município - foi baseada em estudo realizado por uma equipe coordenada pela Arquiteta Paisagista Rosa Grena Kliass nos anos de 1984 e 1985. Esse trabalho resultou, em 1988, na publicação do volume "Vegetação Significativa do Município de São Paulo"120.

Como o próprio texto do volume informa em sua introdução, a publicação "não tem o objetivo de ser um extenso e detalhado estudo sobre a vegetação do município." ${ }^{121} \mathrm{Seu}$
118. A Secretaria Municipal do Meio Ambiente (SMMA) teria seu nome alterado para Secretaria do Verde e Meio Ambiente (SVMA) entre os anos de 2001 e 2002. A inserção da palavra "verde" ao nome da secretaria possivelmente seja justificada por razões de ênfase. A idéia de "meio ambiente", por si só, já encontra implícito o imaginário de "verde". Segundo Carlos Alberto da Silva Filho, a idéia colocada na época era diferencia a Secretaria do conceito isolado de Meio Ambiente, associado pelos especialistas da área ao controle de poluição do ar e ao meio abiótico. A palavra "verde" remete à idéia de fauna e flora, mais coerente com a atuação da Secretaria. Informação pessoal fornecida em 09 de Agosto de 2007.

119. Lei Federal 4.771/1965

120. SÃO PAULO (Estado) Secretaria do Meio Ambiente / Secretaria Municipal de Planejamento. Vegetação Significativa no Município de São Paulo. São Paulo, 1988

121. Ibidem. p.01 
122. A título de exemplo, do período de 1980 a 1991 para o período de 1991 a 2000, a taxa de crescimento do bairro de Parelheiro, situado no extremo sul do Município de São Paulo, de Demográficos 1980, 1991, 2000 mérito reside em estabelecer critérios para a valoração das árvores da cidade de São Paulo e, com base nele, realizar o mapeamento de indivíduos e massas arbóreas significativas.

Ao definir onde e porque determinadas árvores não eram passíveis de corte, a publicação (e posteriormente a lei) permitiu estabelecer bases importantes para a futura aplicação das compensações ambientais no município. Desde que foi regulamentada, a definição dos exemplares com imunidade de corte na cidade de São Paulo é baseada no Decreto 30.443, que permanece como referência para esse assunto, ao menos até o ano de 2008.

Embora o estudo original que deu base ao Decreto Estadual constitua um trabalho consistente, mostra-se clara sua desatualização. O levantamento foi realizado em meio às restrições técnicas daquele momento, quando a disponibilidade de mapas e bases aerofotogramétricas era muito inferior à existente com a introdução da informática nessa área.

A obsolescência do documento possibilita que árvores não levantadas oficialmente possam ser consideradas “invisíveis” à ação legal do Poder Público. Isto equivale a dizer que um empreendedor pode retirar determinadas árvores de um terreno não levantado pela prefeitura sem que o Poder Público se dê conta. E, ainda por cima, reduz as possibilidades de puni-lo.

Tais fatos mostram a necessidade de atualizações no cadastramento arbóreo do município. Deve-se levar em conta a adaptação do cadastramento original a uma nova realidade física da cidade, que tem experimentado sucessivas expansões da área urbanizada. $\mathrm{O}$ aumento da acessibilidade a técnicas informatizadas de mapeamento experimentada nos anos 1990 e 2000 possibilita atualizações constantes no cadastramento arbóreo do município, permitindo maior controle da massa arbórea remanescente no município.

Nos cinco anos posteriores ao Decreto Estadual 30.443, a legislação de proteção e fomento à vegetação do município permaneceria sem alterações substanciais, embora o crescimento e o ritmo de expansão das áreas urbanizadas sobre os limites das áreas de proteção do município continuassem preocupantes ${ }^{122}$. 
Em 1994, um ano depois da criação da SMMA, entra em vigor o Decreto Estadual 39.743, que fez a transferência de uma parte significativa das responsabilidades de proteção e fomento à vegetação do Poder Público estadual para o municipal.

Esta vinda de novas responsabilidades para a atual SVMA não correspondeu, necessariamente, ao aparelhamento adequado do Poder Público municipal para a aplicação das leis de proteção à vegetação. Segundo Silva Filho, os procedimentos adotados pelo Poder Público foram:

[...] medidas paliativas para dotar o DEPAVE de uma estrutura capaz de abrigar e responder às demandas da legislação de proteção e fomento da vegetação, uma vez que medida definitiva demandaria a alteração da lei de criação da SVMA. Ressalte-se que tanto a edição da Lei 10.365/87 quanto a edição da lei de criação da SVMA, seis anos mais tarde, poderia ter sido utilizada para reestruturar o DEPAVE, dotando-o da estrutura organizacional necessária para abrigar as novas atribuições estabelecidas. Mesmo havendo técnicos do DEPAVE na composição dos Grupos de Trabalho que elaboraram os respectivos projetos de lei, a opção foi a manutenção da estrutura existente e a acomodação das novas atribuições nessa estrutura, talvez na expectativa de uma pequena demanda, que não se confirmou ao longo do tempo. ${ }^{123}$ 
124. Todos os depoimentos do Eng. Agr. Carlos Alberto da Silva Filho citados neste trabalho referem-se à entrevista realizada no
dia 14.02.2007.

\section{Memorando 41/98 e a Portaria 088/99: o surgimento das compensações em São Paulo}

Apesar da falta de aparelhamento para aplicação da legislação, a relativa autonomia proporcionada pelo Decreto 39.743/94 possibilitava ao DEPAVE a busca por formas de compensação mais efetivas do que aquelas proporcionadas pela simples reposição. Segundo Carlos Alberto da Silva Filho ${ }^{124}$, o detalhamento dos procedimentos para compensação era aspirado pelo DEPAVE há algum tempo. Para viabilizar essa intenção, alguns técnicos relacionados às autorizações de retirada arbórea implantaram gradualmente, com base em interpretações da lei 10.365/87, medidas alternativas à reposição até então existente. Inicialmente, até mesmo em função da falta de respaldo e apoio do Poder Público, o estabelecimento dos critérios para a quantia compensatória eram bastante subjetivos. Segundo Silva Filho, que trabalhou no DEPAVE nessa época, a quantia compensatória daquele momento variava "em função do humor" do diretor do Departamento, que era responsável pelas autorizações. Quanto menos bem humorado estivesse, maior seria a quantia compensatória.

A busca por critérios mais embasados e específicos para lidar com a supressão arbórea motivou, no ano de 1997, as primeiras medidas tomadas pelo DEPAVE no sentido de instituir a compensação ambiental no município. Diversas discussões ocorreram a respeito do assunto entre os diversos técnicos do departamento relacionados a essa área. Segundo Silva Filho, que participou das discussões daquele momento, os critérios para compensação ambiental deveriam basear-se em três princípios: o porte, o valor ecológico e a localização.

A reunião das diversas idéias sobre compensações ambientais desenvolvidas neste período foi compilada em um documento interno ao departamento, intitulado Memorando $\mathrm{n}^{\circ}$ 41/DEPAVE-G/98. Embora não tivesse a influência de uma Portaria, tal documento serviria como orientação provisória (mas pioneira) para os procedimentos de compensação ambiental no município, sistematizando as discussões sobre o assunto ocorridas no DEPAVE até então. 
O memorando 41 é o primeiro documento a normatizar a compensação ambiental no município, estabelecendo o plantio de árvores em quantidades maiores do que a removida pelo empreendedo. Foram utilizados quatro critérios para estabelecer a proporção compensatória:

- Diâmetro à altura do peito (DAP) do exemplar. Foram estabelecidas três classes de DAP sujeitas a diferentes proporções compensatórias. Quanto maior o DAP, maior a quantia compensatória.

- Motivo da remoção: uso público ou privado do terreno onde ocorreu o dano ambiental. As proporções eram idênticas para ambos. A diferenciação ocorria na exigência de mudas compensatórias para a retirada de árvores em estado fitossanitário ruim ou com risco de queda iminente em propriedades privadas. Assim como nos outros casos, a proporção de mudas variava em função do DAP.

- Tipo de remoção: corte ou transplante. Por meio desse critério, o transplante passa a ser considerado um tipo de dano ambiental, na medida em que sua realização aumenta o risco de morte da árvore. Ao mesmo tempo, a medida desestimula o manejo de árvores por razões corriqueiras, buscando inibir a prática profissional corrente - e ambientalmente prejudicial - pela qual se modifica a posição de árvores no terreno ao invés de alterar o projeto.

- Compensação interna ou externa ao terreno onde ocorreu o dano, para os casos de propriedades particulares. Caso ocorresse no próprio terreno, o fornecimento da muda ao viveiro municipal era suficiente. Se a compensação fosse externa, exigiamse protetores para as mudas compensatórias.

O documento também menciona o uso do instrumento "Termo de Compromisso Ambiental" (TCA) como forma de estabelecer um vínculo entre o empreendedor e a SVMA para realização da compensação ambiental. Possibilita-se desse modo, que mesmo no caso de descumprimento das obrigações compensatórias, as mesmas possam ser cobradas pelo Poder Público a qualquer momento. O papel desempenhado pelo TCA em relação aos processos de compensação ambiental no município é relevante a ponto 
destes dois conceitos se fundirem. Não é raro se ouvir a designação (errônea) "Termo de Compensação Ambiental”, até mesmo em placas de divulgação e informativos da própria prefeitura.

Por fim, o memorando detalha características da mudas compensatórias, algo que não ocorria na lei 10365/87: "As mudas utilizadas pela compensação deverão ter, no mínimo, altura de 2,5 a 3,0m, sendo $1,8 \mathrm{~m}$ do colo à primeira bifurcação, e D.A.P. - diâmetro à altura do peito - de $3 \mathrm{~cm}$. ${ }^{125}$

Antes mesmo do surgimento de Portaria regulamentando as compensações ambientais no município, começariam a surgir os primeiros projetos resultantes do uso desse mecanismo:

O primeiro TCA foi celebrado com a construtora Birmann, em abril de 1997, e previa como medidas compensatórias à remoção de exemplares arbóreos, para a implantação de um edifício de apartamentos (no bairro do Morumbi), o desenvolvimento de projeto paisagístico para uma área pública de trinta mil metros quadrados e o plantio e urbanização, segundo esse projeto, de metade da área. O plantio e urbanização da outra metade ficaram estabelecidos como medida compensatória no segundo TCA, celebrado com o Carrefour, em função das remoções autorizadas para implantação de um hipermercado da rede, próximo à ponte João Dias, sobre o Rio Pinheiros ${ }^{126}$

Datam desse mesmo período o surgimento dos processos de compensações ambientais geradas pelos empreedimentos Villagio Panamby (distrito do Morumbi) e Hospital Alemão Oswaldo Cruz (distrito de Bela Vista).

Do aperfeiçoamento do Memorando 41/1998, surgiria, um ano depois, a Portaria 088/ SVMA.G/99. O documento regulamenta e detalha diversos procedimentos propostos em seu precursor:

- Aumento de três para sete classes de compensação determinadas em função do DAP. Foram aumentadas também as quantias de mudas necessárias à compensação de cada uma dessas sete categorias. Além disso, dobrou-se a quantia de mudas para compensação pela retirada de árvores com estado fitossanitário ruim ou risco eminente de queda. 
- Detalhamento dos referenciais de mudas para compensação, acrescendo às definições de porte da muda a necessidade de consulta às "Normas e especificações para o recebimento de mudas de árvores" e a uma listagem oficial de árvores do DEPAVE/SVMA.

- Estabelecimento de um prazo de trinta dias para cumprimento da medida compensatória, a partir do momento no qual o dano foi realizado, seja ele corte ou transplante. Em seguida, porém, relativiza e praticamente anula essa determinação ao informar que o prazo poderia ser "outro estabelecido pelo DEPAVE"127. Segundo Silva Filho, essa flexibilização se aplica aos casos de plantio compensatório no interior do lote. Caso o empreendedor fosse obrigado a plantar no prazo de trinta dias, mesmo sem ter concluído sua obra, haveria o risco de se causar danos ou inviabilizar o plantio.

A Portaria também estipula um prazo para manutenção de mudas plantadas externamente ao terreno causador do dano, preenchendo uma lacuna existente desde a Lei 10.365/87. A definição nova de um período de manutenção de 24 meses, no entanto, está presente na parte relativa a compensações em maciços arbóreos existentes. Fica ambíguo se o prazo estabelecido refere-se ao caso específico de compensações em maciços arbóreos ou é válida para todos os casos citados nessa legislação.

Outro acréscimo em relação ao Memorando 41 é a existência de uma exceção, concedida para compensações que envolvessem enriquecimento arbóreo de áreas existentes. Nesses casos, foi possibilitada a redução do porte da muda compensatória. Mas não foram estabelecidos parâmetros que definissem o que é entendido como enriquecimento arbóreo pelo DEPAVE (embora este já fosse um conceito consolidado entre os técnicos), nem quanto seria essa redução. 
128. SAKATA, Francine Gramacho. O projeto paisagístico como instrumento de requalificação urbana. Dissertação de Mestrado. São Paulo, FAUUSP, 2004.

129. SAKATA, Francine Gramacho. O projeto paisagístico como instrumento de requalificação urbana. Dissertação de Mestrado. São Paulo, FAUUSP, 2004.

130. Modalidades são formas alternativas ao plantio de árvores compensatório, estabelecidas pelo poder público.

\section{Gestão Marta Suplicy: a consolidação das compensações ambientais no município}

A Gestão de Marta Suplicy (2000-2004), do Partido dos Trabalhadores (PT), corresponde a um período no qual a legislação de compensação ambiental sofreria importantes alterações. Essas modificações apresentam relação direta com o papel desempenhado pelos projetos paisagísticos nessa gestão.

Sakata afirma que "a construção de imagens através de projetos paisagísticos tomou forma na gestão de Marta Suplicy"128. De fato, esta gestão priorizou a construção de espaços livres públicos como há muito não se fazia no município. Tome-se como exemplo o Programa Centros de Bairro, deixado a encargo da EMURB, que executou um total de 49 praças, distribuídas em diversas localidades do município, entre os anos de 2001 e $2004^{129}$.

Na Gestão Marta Suplicy ocorreriam maiores impulsos para a construção de espaços livres custeados por compensações ambientais. Tal fato encontra-se em consonância com a política de construção de espaços livres adotada nessa gestão. Embora as bases da legislação de compensação ambiental em São Paulo tenham surgido na Gestão de Celso Pitta (1995-1999), foi na gestão seguinte que ela assumiria relevância como ferramenta viabilizadora da implantação de espaços livres no município.

\section{Portaria 122/2001: novas formas de compensação}

A primeira revisão dos mecanismos de compensação no município ocorreria em 2001, por meio da Portaria DEPAVE 122. A modificação mais importante introduzida por esse documento foi a criação de novas modalidades compensatórias ${ }^{130}$. Essas alternativas só poderiam ser adotadas caso o número total de mudas previstas na compensação extrapolasse a área passível de plantio no próprio terreno que gerou o dano ambiental.

Até então, segundo a Portaria 088/99, a compensação prevista para esses casos restringia-se ao acréscimo de protetores às mudas plantadas fora do terreno que gerou o dano - visando evitar perdas por vandalismos. Essa possibilidade foi mantida, mas além do plantio, passou a ser exigida a manutenção das mudas compensatórias pelo causador do dano por um período de dois anos. Além desta, passaram a ser possíveis outras três alternativas: 
- Entrega de mudas à prefeitura para os casos de terrenos com área inferior a $500 \mathrm{~m}^{2}$, em quantia igual ao dobro do número de árvores retiradas. Essa possibilidade só era válida para situações que envolvessem a retirada ou corte de poucas árvores (no máximo cinco exemplares), de modo a evitar o acúmulo de mudas em viveiros da prefeitura.

- Urbanização ou melhoria de área verde pública municipal, cujo valor do serviço deveria ser calculado por fórmula fornecida na própria Portaria. A fórmula levava em conta o valor estabelecido pela prefeitura para as mudas compensatórias e para serviços de urbanização (mobiliários, caminhos e áreas de estar). A área do serviço compensatório era proporcional à projeção das copas das árvores retiradas, método sujeito a diversas imprecisões de cálculo. $\mathrm{O}$ uso dessa alternativa não excluía a necessidade de um plantio mínimo compensatório, cuja quantidade era de $20 \%$ das mudas compensatórias ou o dobro das árvores retiradas (o que fosse maior). Assim como no caso de doação de mudas, o causador do dano se responsabilizava pela manutenção dos serviços executados por dois anos.

- Aquisição de terreno para incorporá-lo ao sistema de áreas verdes do município. Essa área poderia ser arborizada ou não, com preferência para a primeira opção. Assim como no caso de obras, o critério utilizado para determinar o tamanho do terreno a ser adquirido era a área da projeção das copas de árvores retiradas. O surgimento dessa alternativa busca solução para um problema cada vez mais freqüente em grandes cidades como São Paulo: a redução do estoque de terrenos disponíveis para a implantação de espaços livres públicos municipais.

A idéia de trocar árvores por outras modalidades de compensação surgiu do questionamento de casos que envolviam áreas ajardinadas sobre laje. Até a publicação da Portaria 122/2001, a compensação pela retirada de árvores poderia ser feita tanto por meio do plantio em áreas permeáveis quanto em canteiros sobre laje. O prejuízo dos casos de plantio sobre laje era evidente, pois implicava perdas de área permeável em relação àquela onde originalmente estava a árvore. Se a compensação até aquele momento poderia resultar em áreas impermeabilizadas, por que não utilizá-las como instrumento compensatório? 
Essa questão motivou o estabelecimento de uma fórmula para cálculo que previsse o aumento da quantia compensatória para os casos de plantio em áreas impermeáveis, de forma a compensar (ao menos parcialmente) as perdas de área permeável.

Stela Goldenstein - Secretaria Municipal do Meio Ambiente nessa época - partiu dessa mesma questão para propor a idéia de que a compensação pela retirada de árvores poderia, dentre outros modos, ser feita por meio de áreas construídas em espaços livres públicos.

A priori, tal raciocínio pode parecer um contra-senso: trocam-se árvores (e a permeabilidade dos solos a elas atrelada) por elementos construídos, que aumentam a taxa de impermeabilização da cidade. Mas por outro lado, a implantação de equipamentos em espaços livres públicos permite assegurar a função recreativa dessas áreas, contribuindo para preservá-las.

Além disso, a possibilidade de realizar obras e serviços como parte da compensação estabelece uma "moeda de troca" atraente para o setor da construção civil, que pode saldar sua dívida com o próprio serviço ao qual está habituado a trabalhar. Pode-se, desse modo, reduzir o tempo do processo compensatório. Vale ressaltar que essa modalidade constitui uma exceção, tendo sido preservado um patamar mínimo de plantio obrigatório.

Os esquemas ilustrativos representam as alternativas compensatórias permitidas a partir de 2001: 


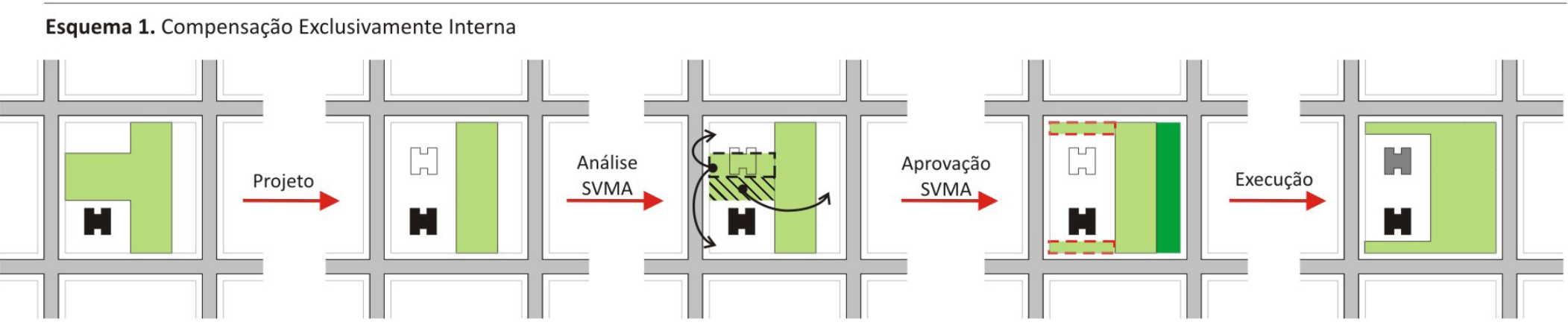

Legenda

1 Edificação existente

Esquema 2. Compensação Exclusivamente Externa

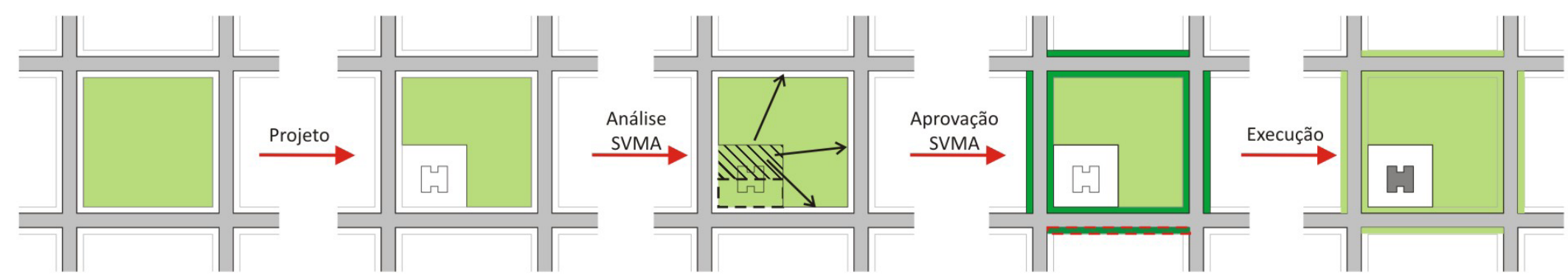

Edificação proposta

Edificação concluída

Vegetação existente

MIV Remoção autorizada

Plantio

compensatório à remoção

Esquema 3. Compensação Interna e Externa

Manejo

$1-\mathcal{L}$ Autorizado

Origem
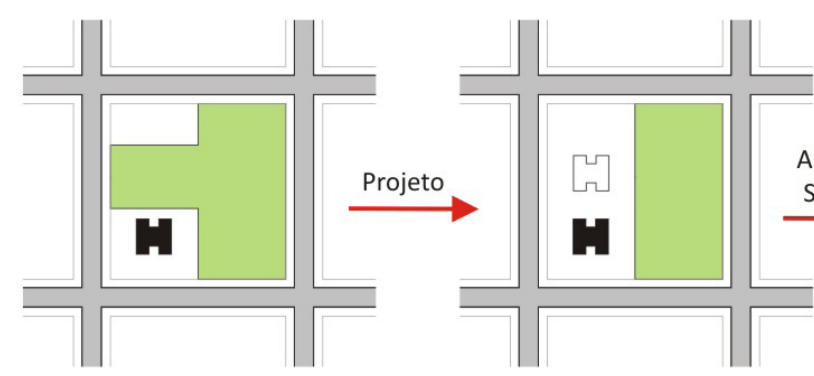

PROPOSTA EMPREENDEDOR
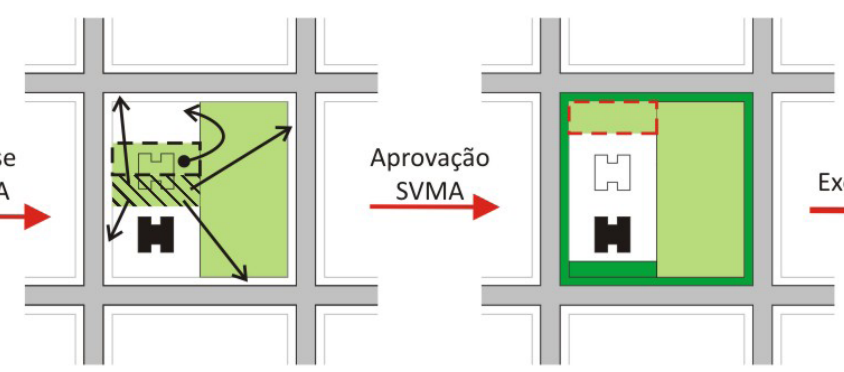

SITUAÇÃO ORIGINAL

PROJETO DE COMPENSAÇÃo

COMPENSAÇÃO APROVADA

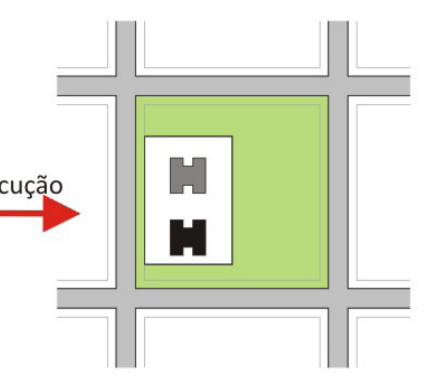

Manejo

$1-\neg$ Manejo Destino 
Esquema 4.

Possibilidades de conversão

da medida compensatória

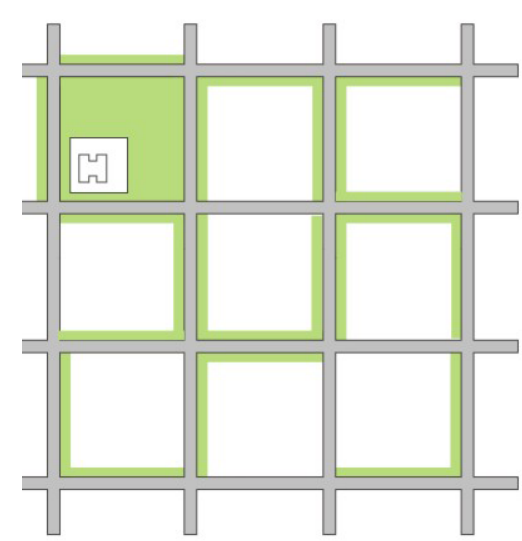

PROPOSTA EMPREENDEDOR

\section{Legenda}

[G] Edificação proposta

Edificação concluída

Vegetação existente

MV Remoção autorizada

Plantio compensatório à remoção
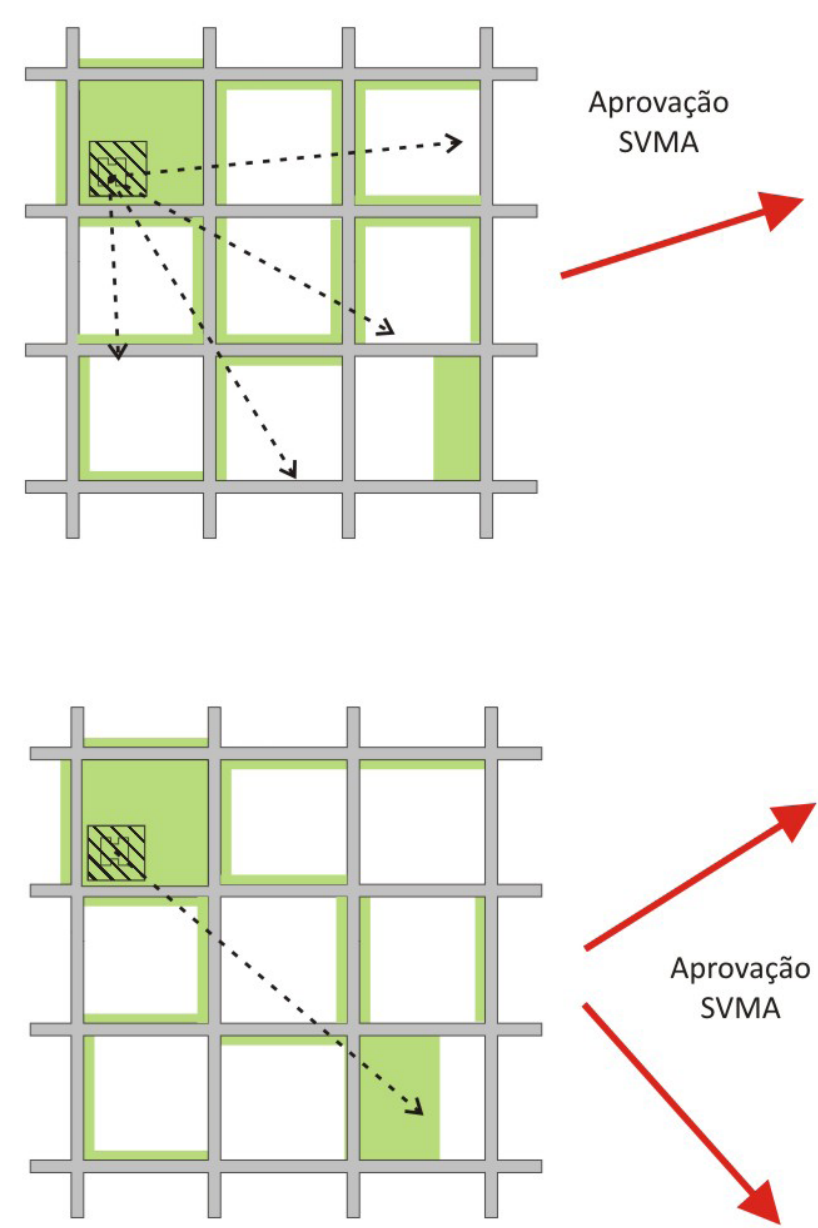

PROJETO DE COMPENSAÇÃO

Aprovação

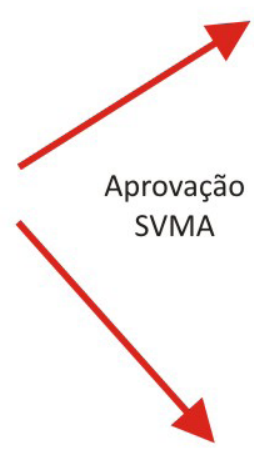

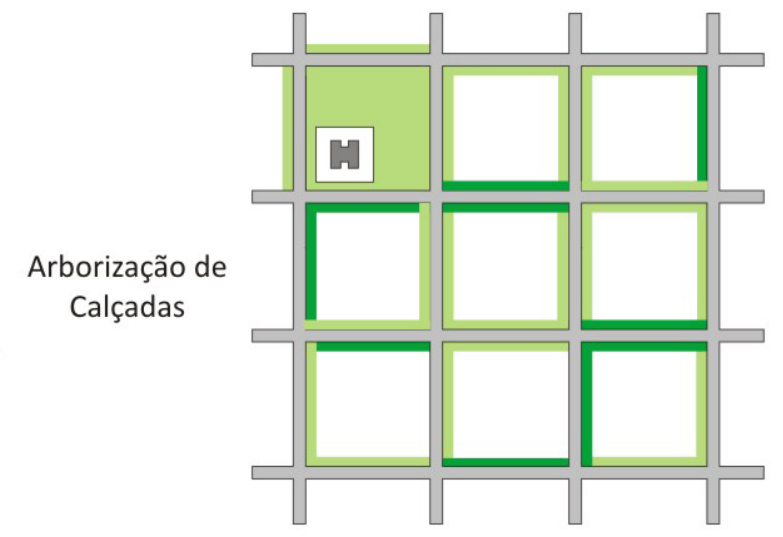

Análise SVMA

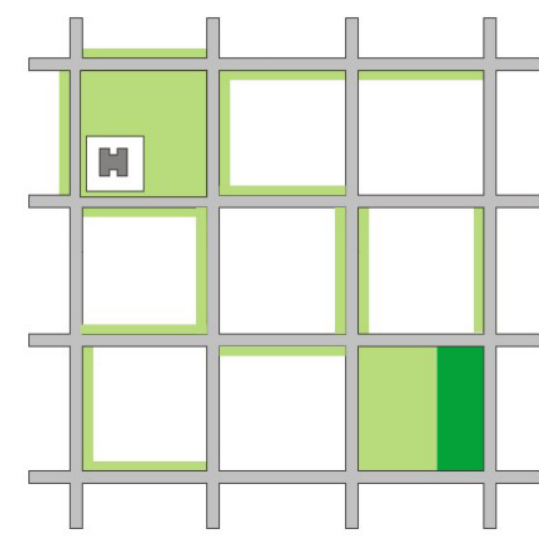

Aquisição de Área Verde

Arborização

$+$

Serviços e Obras

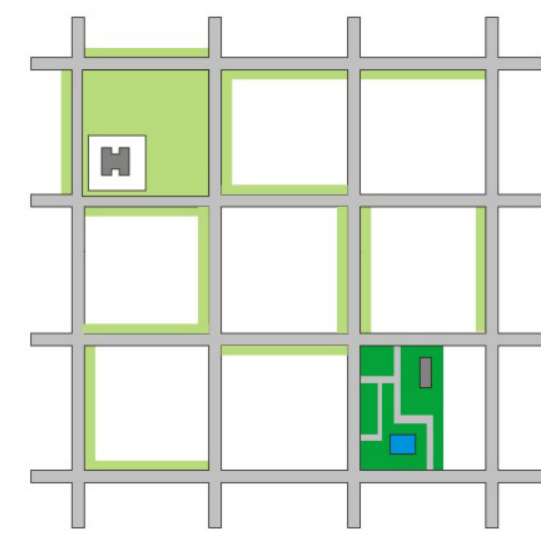

rOMADENICA 
No esquema 1, a construção de um novo edifício implica a retirada de árvores cuja quantia compensatória (o dobro do retirado) cabe dentro do próprio terreno.

No esquema 2, o terreno original encontra-se completamente vegetado. A construção do edifício implicará a compensação de uma quantia de árvores que não cabe no terreno. Nesse caso, será necessário o plantio compensatório nas calçadas do próprio lote do empreendimento e nas adjacentes.

No esquema 3, o terreno comporta uma parte do plantio compensatório, mas foi necessário o plantio complementar nas calçadas do lote para que fosse cumprido a quantidade total necessária.

O esquema 4 ilustra um caso no qual a quantia compensatória não cabe no terreno do empreendimento nem no seu entorno, devido ao grau de arborização existente nas adjacências. Nessa situação o DEPAVE solicitará ao causador do dano a arborização de calçadas na mesma região do empreendimento ou as novas modalidades compensatórias previstas na Portaria 122/01: aquisição de novos espaços livres para o Poder Público ou realização de melhorias (serviços e obras) em espaços livres públicos existentes.

Além de permitir novas modalidades compensatórias, a Portaria 122/2001 introduz diversos outros aperfeiçoamentos:

- Estabelece que o custeio, plantio e manutenção compensatórios devem ser feitos pelo empreendedor.

- Introduz fórmulas para cálculo da conversão das mudas compensatórias em outras modalidades previstas na legislação. $\mathrm{O}$ estabelecimento de fórmulas denota o amadurecimento da legislação, com a introdução de critérios mais objetivos.

- Amplia e detalha as proporções compensatórias em função do DAP para casos de arborização. Cresce a precisão da exigência, ampliando-se os grupos de DAP de 3 para 7. Aumentam-se também as quantidades de mudas exigidas como compensação, que passam do patamar máximo de 6 (Portaria SVMA 088/99) para até $60^{131}$
131. Esse caso refere-se à remoção por corte de árvores com mais de $1,50 \mathrm{~m}$ de DAP. 
- Estabelece a necessidade de um projeto paisagístico de compensação ambiental (PCA), a ser custeado e contratado pelo proprietário da obra. O texto da legislação também detalha os diversos procedimentos e padrões para tais projetos.

- Especifica um prazo de até 24 meses, contados a partir da entrega oficial, durante o qual o proprietário é responsável pela manutenção das mudas plantadas, obra ou serviços compensatórios.

Três anos depois de regulamentada legalmente ${ }^{132}$ a compensação ambiental já estava consolidada como instrumento legal. Sua utilização permitiu, por exemplo, o custeio parcial de dois espaços livres públicos municipais: a Praça Nandina Haddad Ambudda, no bairro do Morumbi e o Parque do Cordeiro, no bairro de Santo Amaro ${ }^{133}$. Sem verbas específicas para investimento em novos espaços livres públicos, a prefeitura buscou ampliar o papel das compensações ambientais como instrumento de custeio.

Em 2002, o "Termo de Compromisso Ambiental” (TCA) é incorporado ao texto do Plano Diretor Estratégico do município, reforçando a importância das compensações ambientais em São Paulo. No Plano Diretor, o TCA é definido como sendo um "documento a ser firmado entre o Poder Público e pessoas físicas ou jurídicas, resultante da negociação de contrapartidas nos casos de autorização prévia para supressão de espécies arbóreas" ${ }^{\text {134 }}$. O mecanismo aparece no texto da lei como um Instrumento de Gestão Ambiental de caráter punitivo juntamente com o Termo de Ajustamento de Conduta.

Ao mesmo tempo em que se detalha o texto da legislação, busca-se o melhor aparelhamento do DEPAVE para a aplicação da mesma. Por esse motivo, cria-se ainda no ano de 2002, o Núcleo para Proteção e Fomento à Legislação do Município de São Paulo (NLPFV) ${ }^{135}$, vinculado diretamente ao gabinete da SVMA. Com essa medida buscou-se maior autonomia para aplicação da legislação de proteção e fomento à vegetação do município, na qual as compensações desempenhavam papel cada vez mais importante. 
Portaria 136/2003 e 26/2004:

\section{o uso das compensações como instrumento político}

Por meio da publicação da Portaria 136 no ano de 2003, as compensações consolidam sua relevância como ferramentas viabilizadoras da implantação de espaços livres no município. Um dos principais pontos modificados por essa Portaria foi a generalização da parte referente às alternativas compensatórias:

[...] DEPAVE definirá a forma de compensação que poderá ser através da execução de obras, serviços, projetos em geral, plantio no próprio terreno ou em outro local, entrega de mudas com os respectivos protetores, ou ainda, outra forma definida pela Administração para a implantação de novos Parques ou recuperação dos existentes. ${ }^{136}$

O texto possui um caráter mais genérico e ambíguo, contrapondo-se à especificidade da Portaria 122/2001. A Portaria 136/2003 não faz menções às situações nas quais cada uma das alternativas de compensação ocorreria, nem à proporção que deveriam respeitar. Tudo ficava subordinado aos critérios do DEPAVE e, indiretamente, aos interesses da gestão vigente. A menção específica à “implantação de novos parques” evidencia como essa medida visava facilitar a construção de obras entendidas como prioritárias naquele momento de véspera de eleição. Não por coincidência, os parques Jacintho Alberto e Vila Prudente, beneficiados pela Portaria 136, teriam suas primeiras fases inauguradas exatamente no último dia da gestão Marta Suplicy (31/12/2004). Outros dois parques (Cordeiro e Pinheirinho D’Água) receberiam investimentos fragmentados nesse mesmo momento, mas não seriam executados totalmente até então.

Outras diversas inovações foram introduzidas por essa Portaria, dentre as quais se destaca:

- Introdução de novos conceitos de valoração ecológica, de forma rudimentar e ainda pouco clara. O texto da legislação menciona que "exemplares arbóreos significativos e de grande importância"137 estão sujeitos a aumentos na quantia compensatória. Não se estabelece, no entanto, quais seriam os casos e qual seria esse aumento. 
- Estabelecimento de um fator redutor de até 50\% para compensações ambientais que envolvessem cortes e transplantes em obras de Habitações de Interesse Social (HIS). A porcentagem estabelecida ficava a critério da SVMA, sem fórmulas específicas para o cálculo. Nos casos de cortes irregulares em obras de HIS, a Portaria amenizava a punição, exigindo um acréscimo de $10 \%$ na quantia de mudas compensatórias - contra 30\% estabelecido para outros casos. Tais medidas visavam claramente facilitar a aprovação de projetos da área habitacional. Essa postura seria mantida e até mesmo ampliada na gestão subseqüente.

- Mudança do prazo de manutenção do plantio de mudas compensatório exigido ao proprietário. Enquanto antes eram previstos necessariamente 24 meses, a Portaria 136 flexibiliza o período para 6 a 24 meses. Assim como ocorre com a determinação do tipo de modalidade compensatória, o prazo de manutenção passa a ficar a critério do SVMA. Note-se que esse prazo passa a ser exigido apenas para as compensações por plantio. Os prazos de manutenção para as alternativas compensatórias, antes previstos pela legislação, agora não seriam mais mencionados.

- Estabelecimento de acréscimos de 30\% na quantia compensatória para os casos de cortes irregulares de árvores - ou seja, aqueles que não foram autorizados pelo SVMA. Antes disso, os casos constatados pela prefeitura estavam sujeitos à mesma penalidade que aqueles legalmente adequados. Isso poderia desincentivar as ações legalmente adequadas, cuja aprovação geralmente é mais demorada.

- Aumento da complexidade do cálculo do valor compensatório. Cria-se um fator de correção para determinar a quantia compensatória final, no qual se adota um índice que considera 10\% das árvores com maiores DAPs a serem retiradas. Desse modo, busca-se reduzir imprecisões na determinação da quantidade de mudas a serem pagas pelo causador do dano ambiental.

- Detalhamento das exigências do projeto de compensação ambiental, cuja necessidade estava prevista à partir da Portaria 122/2001.

- Detalhamento das responsabilidades do DEPAVE e das Subprefeituras perante as compensações ambientais. Esses procedimentos estavam previstos de forma genérica na Lei Municipal 10.365/87. Observa-se a descentralização de diversos procedimentos antes sob responsabilidade do DEPAVE, que fica responsável pelos casos de maior porte. 
- Criação da possibilidade de entrega de projetos paisagísticos como modalidade compensatória.Tal alternativa passou a permitir que se custeasse projetos para espaços livres públicos separadamente à sua execução. Se por um lado essa desvinculação facilitou a viabilização de novos espaços livres; por outro criou descontinuidades entre o projeto paisagístico e sua execução.

Vale ressaltar que embora traga essa série de inovações, paradoxalmente a Portaria 136/2003 apresentaria um texto menos detalhado que a Portaria antecessora. Parte das dubiedades presentes no texto da Portaria 136/2003 foi esclarecida pela Portaria SVMA 26/2004. As principais modificações colocadas pelo documento foram:

- Redução das proporções compensatórias, tanto para os casos de transplante quanto para situações de remoção. Os fatores passam a variar de 2:1 (remoção por transplante para DAP 5 a 10cm) a 45:1 (remoção por corte para DAP maior que 150cm). Na Portaria 136/2003, essas proporções eram respectivamente 3:1 e 60:1. Esse novo patamar adotado foi mantido pela legislação subseqüente. A redução na quantia compensatória possivelmente se deva a pressões exercidas pelo mercado imobiliário.

- Detalhamento dos procedimentos para compensações em casos de Habitações de Interesse Social (HIS). Passa a ser exigido o plantio obrigatório do dobro do número de árvores retiradas ou uma quantia de $20 \%$ do total a ser compensado (o que for maior). Antes, tal informação não era mencionada, possibilitando a compensação exclusiva por modalidades como obras e serviços. A partir desse momento, fica estabelecido que as modalidades possíveis nesse caso são: obras e serviços, projetos paisagísticos, entrega ao viveiro ou plantio no terreno ou entorno. A decisão ficava a critério do DEPAVE.

- Delimita-se a possibilidade de conversão da medida compensatória apenas para os casos existentes no inciso I do Art. 11 da Lei Municipal 10.365/87. Tal artigo especifica que “ [...] a supressão ou a poda de árvores só poderá ser autorizada [...] em terreno a ser edificado, quando o corte for indispensável à realização da obra [...]”. Fica esclarecido, desse modo, que a conversão de modalidade só pode ser utilizada em casos devidamente justificados pelo empreendedor, não sendo válida para quaisquer situações. Esse era um dos pontos mais polêmicos da Portaria 136/2003. 
138. Com a candidatura e posterior eleição de José Serra para o Governo do Estado de São Paulo, em 2006 o VicePrefeito Gilberto Kassab, do Partido Democratas (DEM), assumiu o comando da prefeitura. Por esse motivo, este trabalho refere-se a uma Gestão Serra/Kassab

139. Informação confirmada por vários técnicos da SVMA entrevistados para esta pesquisa.

140. Embora a cidade tivesse passado por diversas gestões de partidos com linha de atuação semelhante (tais como o PMDB), era a primeira vez que o PSDB atuava de forma direta no município.

\section{Gestão Serra/Kassab (2005 a 2008)}

O início do mandato de José Serra ${ }^{138}$, do Partido da Social Democracia Brasileira (PSDB) na prefeitura do município provocou expectativa com relação ao destino das compensações ambientais na cidade, dada a prática brasileira corrente de não dar continuidade aos trabalhos das gestões anteriores, sobretudo entre partidos de bandeiras opostas.

$\mathrm{O}$ que se observou foi, de fato, uma ruptura com as posturas da gestão anterior. Mas antes disso, ocorreu um processo de retração da nova gestão. Essa redução de ritmo é comum nas mudanças de gestão ${ }^{139}$, constituindo uma espécie de "reconhecimento inicial de terreno". No caso do PSDB essa situação se acentuou, pois o partido nunca tivera experiências anteriores na prefeitura do município ${ }^{140}$. Tal fato fica evidenciado por uma abrupta redução no número de compensações no ano de 2005 (ver gráfico), que contrariou uma lógica de aumento gradativo que ocorrera durante a Gestão anterior.

Tabela 1. Andamento dos processos de compensação ambienta na cidade de São Paulo entre os anos de 1997 e 2007

\begin{tabular}{|c|c|c|c|c|}
\hline data & $\begin{array}{c}\text { processos } \\
\text { finalizados }\end{array}$ & $\begin{array}{c}\text { processos em } \\
\text { cumprimento }\end{array}$ & $\begin{array}{c}\text { processos não } \\
\text { acompanhados }\end{array}$ & $\begin{array}{c}\text { Qtde total de } \\
\text { processos }\end{array}$ \\
\hline 1997 & 4 & 5 & 4 & 13 \\
\hline 1998 & 7 & 10 & 32 & 49 \\
\hline 1999 & 24 & 18 & 47 & 89 \\
\hline 2000 & 23 & 24 & 28 & 75 \\
\hline 2001 & 25 & 29 & 27 & 81 \\
\hline 2002 & 46 & 40 & 10 & 96 \\
\hline 2003 & 59 & 87 & 7 & 153 \\
\hline 2004 & 66 & 102 & 5 & 173 \\
\hline 2005 & 11 & 32 & 1 & 44 \\
\hline 2006 & 7 & 116 & 1 & 124 \\
\hline 2007 & 7 & 188 & 0 & 195 \\
\hline
\end{tabular}

Fonte: SVMA (2008) 
Passado o momento de retração, começaram a ser propostas mudanças no funcionamento dos TCAs, até mesmo como forma de simbolizar uma nova gestão. Essas alterações foram centradas no conceito orientador das compensações. Em contraposição à valorização das obras e serviços levada a cabo na gestão do PT, a gestão do PSDB - representada na SVMA pelo médico sanitarista Eduardo Jorge Caldas Pereira - buscaria a valorização da arborização urbana. Tal postura, denominada por Silva Filho como "conservacionista"141, fica evidenciada no aperfeiçoamento das questões relacionadas à valoração ecológica e à redução da possibilidade de compensações por obras e serviços. A adoção de tais princípios representa um retorno a princípios estabelecidos pela legislação compensatória anterior à gestão Marta Suplicy. A realidade da aplicação do mecanismo encarregou-se de mostrar gradativamente que o retorno à arborização urbana não traria os resultados esperados.

\section{Portaria 009/2005: o detalhamento como forma de ruptura}

Os reflexos da postura da nova gestão ocorreriam em 2005, quando entra em vigor a Portaria 009. O texto da nova legislação detalha diversas questões presentes na Portaria 136/2003, cuja falta de clareza do texto auxiliou a execução de obras prioritárias naquele momento. Este é o caso da proporção compensatória ambígua, que possibilitava o uso de elevadas quantias compensatórias para a execução dos espaços livres públicos, priorizados pela Gestão Marta Suplicy.

Além disso, apresenta aperfeiçoamentos dos critérios de valoração ecológica. Sintonizados com legislações ambientais presentes em outras cidades do Brasi $1^{142}$, esses critérios demonstram uma atuação mais forte de profissionais da área de Engenharia Agronômica e Florestal em sua elaboração, fortemente vinculados à valorização do papel da arborização nas cidades.

Outra mudança realizada em relação à gestão anterior foi a nova ampliação do leque de alternativas de compensação, sendo acrescentadas as seguintes possibilidades:

- limpeza de corpos hídricos;

- elaboração e execução de programas e de projetos de educação ambiental;

- doação de equipamentos, ferramentas e insumos para uso em projetos de recuperação ambiental da SVMA;
141. SILVA FILHO, Carlos Alberto da. Proteção e fomento da vegetação no Município de São Paulo: possibilidades, alcance e conflitos. Tese de doutorado. São Paulo, FAUUSP, 2005

142. Uma das principais bases foi a legislação da cidade do Rio de Janeiro. A comparação da legislação compensatória carioca e paulistana será feita mais adiante neste trabalho. 
Tais novas possibilidades denotam maior detalhamento das modalidades compensatórias, facilitando o direcionamento dos recursos obtidos por meio de compensações.

Também foram realizadas mudanças nos patamares mínimos de compensação por plantio. A Portaria 136/2003 permitia a compensação de até 100\% dos danos ambientais com obras civis - ao menos hipoteticamente, tendo em vista a dubiedade de seu texto. A nova Portaria limita esse patamar pela metade:

[...] o valor monetário da medida compensatória poderá ser convertido em outras modalidades de compensação ambiental, desde que seja resguardado o mínimo obrigatório de $50 \%$ (cinqüenta por cento) da compensação final (CF) para o plantio de mudas. ${ }^{143}$

A porcentagem do valor compensatório é um dos itens que sofreu maiores modificações ao longo do histórico das compensações na cidade de São Paulo. Esse indicador evidencia conflitos entre a postura da gestão anterior e a nova, que respectivamente priorizaram obras civis e o uso da vegetação como medida compensatória. Esses contrastes ficam evidenciados na tabela 2:

\begin{tabular}{|c|c|c|c|c|c|c|}
\hline $\begin{array}{l}\text { Tabela 2. Conversão da } \\
\text { medida compensatória }\end{array}$ & $\begin{array}{c}\text { Lei } \\
10365 / 87\end{array}$ & $\begin{array}{l}\text { Portaria } \\
088 / 99\end{array}$ & $\begin{array}{l}\text { Portaria } \\
122 / 01\end{array}$ & $\begin{array}{l}\text { Portaria } \\
136 / 03\end{array}$ & $\begin{array}{l}\text { Portaria } \\
009 / 05\end{array}$ & $\begin{array}{l}\text { Portaria } \\
005 / 06\end{array}$ \\
\hline $\begin{array}{l}\text { arborização e/ou plantio (com } \\
\text { manutenção obrigatória) }\end{array}$ & $100 \% *$ & $100 \%$ & mín 20\% & até $100 \%$ & mín 50\% & mín 50\% \\
\hline $\begin{array}{l}\text { obras e serviços (com } \\
\text { manutenção obrigatória) }\end{array}$ & - & - & até $80 \%$ & até $100 \%$ & até $50 \%$ & até $50 \%$ \\
\hline doação de mudas e protetores & - & - & até $100 \%$ & até $100 \%$ & até $50 \%$ & até $50 \%$ \\
\hline projeto paisagístico & - & - & até $80 \%$ & até $100 \%$ & até $50 \%$ & até $50 \%$ \\
\hline aquisição de áreas verdes & - & - & até $100 \%$ & até $100 \%$ & até $50 \%$ & até $100 \%$ \\
\hline outras benfeitorias & - & - & - & até $100 \%$ & até $50 \%$ & até $50 \%$ \\
\hline educação ambiental & - & - & - & - & até $50 \%$ & até $50 \%$ \\
\hline limpeza de corpos hídricos; & - & - & - & - & até $50 \%$ & até $50 \%$ \\
\hline $\begin{array}{l}\text { doação de equipamentos, } \\
\text { ferramentas e insumos }\end{array}$ & - & - & - & - & até $50 \%$ & até $50 \%$ \\
\hline
\end{tabular}


Além de recapitular os diversos aperfeiçoamentos da gestão anterior - o que confere um tamanho consideravelmente maior ao seu texto - e apresentar melhor nível de organização do seu texto, a Portaria modificou os seguintes aspectos:

- Aumento do prazo para manutenção das mudas compensatórias para 12 a 24 meses. Ressalte-se que cada uma das Portarias analisadas por este trabalho estabeleceu diferentes prazos para manutenção das mudas compensatórias. Isso denota a ausência de consenso quanto ao prazo mínimo necessário, como se pode observar na tabela 3:

\begin{tabular}{l|c|c|c|c|c|c|}
$\begin{array}{l}\text { Tabela 3. Prazo de } \\
\text { manutenção } \\
\text { obrigatório p/ TCAs }\end{array}$ & $\begin{array}{c}\text { Lei } \\
10365 / 87\end{array}$ & $\begin{array}{c}\text { Portaria } \\
088 / 99\end{array}$ & $\begin{array}{c}\text { Portaria } \\
122 / 01\end{array}$ & $\begin{array}{c}\text { Portaria } \\
136 / 03\end{array}$ & $\begin{array}{c}\text { Portaria } \\
009 / 05\end{array}$ & $\begin{array}{c}\text { Portaria } \\
005 / 06\end{array}$ \\
\hline Prazo em meses & $\begin{array}{c}\text { não } \\
\text { definido }\end{array}$ & 24 & 24 & 6 a 24 & 12 a 24 & 12 a 24 \\
\hline
\end{tabular}

- Utilização de bacias hidrográficas como critério para delimitação das áreas a receberem compensações ambientais que não caibam no terreno causador do dano ambiental.

- Detalhamento dos procedimentos para entrega dos projetos de compensação ambiental, com exigências específicas como o padrão gráfico para representação e necessidade de memoriais de cálculo e tabelas padronizadas.

- Estabelecimento de multas para os casos de descumprimento das obrigações assumidas no Termo de Compromisso Ambiental.

- Limitação da quantidade de mudas fornecidas com uma única espécie, tendo em vista o critério da variabilidade ecológica. São estabelecidas porcentagens máximas de cada espécie em relação ao valor total a ser fornecido pelo causador do dano.

- Estabelecimento de uma escala de valoração ecológica, representada por um ente denominado "fator multiplicador" (fm). O fm varia de 1 (menor importância) a 5 (maior importância) e tem por base os seguintes critérios: 
- raridade da espécie;

- potencial paisagístico;

- importância para a fauna (abrigo e alimento);

- segurança ambiental e as condições de permeabilidade do solo;

- localização, características e contato com o entorno.

Ainda em 2005, seria criada a Câmara de Compensação Ambiental do município (CCA) ${ }^{144}$. A CCA (órgão colegiado interno da SVMA) é composta por equipe interdisciplinar de funcionários da SVMA, e tem por objetivo o julgamento dos casos que envolvam conversão da medida compensatória em formas alternativas ao plantio - que por sua vez constituem as situações mais complexas a serem analisadas.

A criação da CCA representa um grande avanço no histórico das compensações ambientais em São Paulo, pois pela primeira vez se estabelece uma equipe específica para analisar os casos de maior complexidade.

O grau de sofisticação e a quantidade de casos existentes no município já haviam gerado subsídios suficientes para a criação da CCA. Sua criação, porém, só ocorreu quase dez anos após a implantação oficial das compensações ambientais no município.

A Portaria que regulamenta a CCA menciona em seu texto a possibilidade de participação de membros da sociedade civil nas discussões sobre o processo de compensação. No entanto, é vedado o seu direito de participação nas reuniões internas da CCA. Por um lado, a participação direta de membros da sociedade civil aumentaria o tempo necessário à aprovação dos processos. Por outro lado, permitiria um processo decisório mais democrático, na medida que permitiria a participação de representantes interesses diversos (tais como mercado imobiliário), enriquecendo as discussões sobre o assunto. 


\section{Portaria 005/2006: a polêmica dos Pinus e Eucaliptos}

Em 2006, entra em vigor a Portaria 005/2006, cuja alteração mais importante - e também mais polêmica - foi a definição da proporção 1:1 no plantio compensatório para eucaliptos e pinus.

Embora a SVMA utilizasse como justificativa técnica a menor relevância ecológica destas duas espécies, tal argumento mostra-se frágil se considerarmos diversos outros aspectos. Por mais que não expressem a realidade da flora brasileira, e mesmo considerando alguns efeitos comprovadamente nocivos da sua presença em relação ao entorno ${ }^{145}$, é difícil imaginar que essas espécies, que ocupam majoritariamente os espaços livres remanescentes no município e cujos portes atingem facilmente a marca dos $20 \mathrm{~m}$ de altura e $50 \mathrm{~cm}$ de DAP, não desempenhem um papel relevante frente à escassa vegetação ainda existente no município.

Para se ter uma idéia da importância numérica que os pinus e eucaliptos representavam em relação às compensações ambientais na cidade, basta mostrar que o corte de um exemplar poderia gerar o plantio de até 60 novas mudas ${ }^{146}$ antes da divulgação da Portaria 009.

Tal Portaria comprometeria os objetivos delineados pela legislação desde seu início, que era a inibição de projetos que envolvessem retiradas de maiores quantias de árvores de um terreno apor meio da elevação dos custos compensatórios. A necessidade de reposição de apenas um exemplar para cada eucalipto ou pinus retirado, torna bem mais interessante ao empreendedor considerar a hipótese de retirada destes dois tipos de árvores.

Na opinião do Eng. Agr. e Arq. José Manoel Gobbi ${ }^{147}$, as mudanças provocadas pela Portaria 005/2006 foram um "tiro no pé do DEPAVE". Para ele, a medida "matou a galinha dos ovos de ouro" da prefeitura, visto que a nova quantia compensatória prevista para pinus e eucalitpto é praticamente irrisória. Anteriormente, esse mesmo tipo de vegetação respondia por uma parcela considerável das compensações do município.
145. Dentre estes efeitos, no caso do Eucalipto, pode-se citar o empobrecimento de nutrientes do solo ao redor da árvore, inviabilizando o crescimento de substratos, e o ciclo de vida relativamente curto da espécie face ao seu desenvolvimento muito acelerado

146. Conforme a Portaria SVMA 009/2005, o plantio de mudas compensatórias no caso da retirada com autorização prévia do órgãos competentes poderia gerar 60 mudas, para compensar um único exemplar de DAP $150 \mathrm{~cm}$

147. Entrevista realizada em 06.04 .2006 
A proporção entre quantias compensatórias e o porte das árvores retiradas foi outro fator que variou bastante ao longo da evolução da legislação, como se pode observar nas tabelas 4 e 5 :

\begin{tabular}{|c|c|c|c|c|c|c|}
\hline $\begin{array}{l}\text { Tabela 4. variação das } \\
\text { proporções compensatórias } \\
\text { na cidade de São Paulo para } \\
\text { remoções por transplante * }\end{array}$ & $\begin{array}{c}\text { Lei } \\
10365 / 87\end{array}$ & $\begin{array}{c}\text { Port } \\
088 / 99\end{array}$ & $\begin{array}{c}\text { Port } \\
122 / 01\end{array}$ & $\begin{array}{c}\text { Port } \\
136 / 03\end{array}$ & $\begin{array}{c}\text { Port } \\
009 / 05\end{array}$ & $\begin{array}{c}\text { Port } \\
005 / 06\end{array}$ \\
\hline
\end{tabular}

\begin{tabular}{|c|c|c|c|c|c|c|}
\hline 05 a 10 & $1: 1$ & $1: 1$ & 1 a $3: 1$ & $3: 1$ & $2: 1$ & $2: 1$ \\
\hline 11 а 30 & $1: 1$ & $3: 1$ & 2 a $6: 1$ & $6: 1$ & $3: 1$ & $3: 1$ \\
\hline 31 а 60 & $1: 1$ & $6: 1$ & 3 a $9: 1$ & $9: 1$ & $6: 1$ & $6: 1$ \\
\hline 61 a 90 & $1: 1$ & $10: 1$ & 5 a $15: 1$ & $15: 1$ & $10: 1$ & $10: 1$ \\
\hline 91 а 120 & $1: 1$ & $14: 1$ & 7 a $21: 1$ & $21: 1$ & $14: 1$ & $14: 1$ \\
\hline 121 a 150 & $1: 1$ & $18: 1$ & 9 a $27: 1$ & $27: 1$ & $18: 1$ & $18: 1$ \\
\hline Maior que 150 & $1: 1$ & $20: 1$ & 10 a $30: 1$ & $30: 1$ & $20: 1$ & $20: 1$ \\
\hline
\end{tabular}

Tabela 5. variação das

$\begin{array}{lcccccc}\text { proporções compensatórias } & \text { Lei } & \text { Port } & \text { Port } & \text { Port } & \text { Port } & \text { Port } \\ \text { na cidade de São Paulo para } & 10365 / 87 & 088 / 99 & 122 / 01 & 136 / 03 & 009 / 05 & 005 / 06\end{array}$
remoções por corte *

\begin{tabular}{|c|c|c|c|c|c|c|}
\hline 05 а 10 & $1: 1$ & $3: 1$ & 2 a $4: 1$ & $4: 1$ & $3: 1$ & $3: 1$ \\
\hline 11 а 30 & $1: 1$ & $8: 1$ & 4 a $8: 1$ & $8: 1$ & $6: 1$ & $6: 1$ \\
\hline 31 а 60 & $1: 1$ & $18: 1$ & 9 a $18: 1$ & $18: 1$ & $9: 1$ & $9: 1$ \\
\hline 61 а 90 & $1: 1$ & $30: 1$ & 15 a $30: 1$ & $30: 1$ & $15: 1$ & $15: 1$ \\
\hline 91 a 120 & $1: 1$ & $42: 1$ & 21 a $42: 1$ & $42: 1$ & $21: 1$ & $21: 1$ \\
\hline 121 a 150 & $1: 1$ & $54: 1$ & 27 a $54: 1$ & $54: 1$ & $30: 1$ & $30: 1$ \\
\hline Maior que 150 & $1: 1$ & $60: 1$ & 30 a 60:1 & $60: 1$ & $45: 1$ & $45: 1$ \\
\hline Morta (com qualquer DAP) & $1: 1$ & $1: 1$ & - & $1: 1$ & $1: 1$ & $1: 1$ \\
\hline Eucalipto e Pinus & $1: 1$ & 3 a 60:1 & 2 a 60:1 & 4 a $60: 1$ & 3 a $45: 1$ & $1: 1$ \\
\hline
\end{tabular}

* em função do tamanho do DAP (em cm) 
Além das mudanças citadas e da incorporação das inovações realizadas anteriormente nas outras Portarias, destacam-se as seguintes modificações:

- Incorporação das Habitações do Mercado Popular (HMP) nos casos de redução da quantia compensatória. Assim como ocorreu com as HIS a partir da Portaria 136/2006, o fator de redução é de até 50\%.

- Redução de 50\% da quantia de mudas compensatórias exigidas no caso de retirada de árvores exóticas. As motivações são semelhantes às que levaram à redução da quantia compensatória para Pinus e Eucaliptus: a valoração ecológica inferior atribuída a esse tipo de vegetação pelos técnicos do DEPAVE e SVMA.

- Refinamento da escala de valoração ecológica para 1 a 10 (contra 1 a 5 da anterior).

- Aumento da possibilidade de compensação por meio de aquisição de terrenos privados para criação de espaço livre públicos para até 100\%. Amplia-se, desse modo, o potencial de um mecanismo muito interessante, mas que até o ano de 2008 ainda apresenta bastante dificuldade para ser aplicado.

- Introdução de novos fatores de amenização da quantia compensatória. São previstas reduções no número de mudas a serem fornecidas nos casos de aumento do DAP em relação ao valor mínimo obrigatório; nos casos de plantio de mudas em 100\% da área permeável existente no projeto; e liberação da necessidade de protetor para os casos de plantio de mudas com DAP superior a $5 \mathrm{~cm}$. Entende-se que o aumento do porte facilita a manutenção da muda e incentiva o fornecimento de material de maior qualidade por parte do empreendedor. Todas essas medidas visam não só tornar mais preciso o processo de compensação, como também estabelecer uma espécie de "incentivo" através da amenização da mesma. 


\section{Decreto 47.145/2006: o futuro do pretérito}

Três meses depois de sua emissão, a Portaria 005 é regulamentada por meio do Decreto $47.145^{148}$. O documento torna-se o texto legal mais importante relativo a compensações ambientais na cidade de São Paulo, depois do art. 251 do Plano Diretor Estratégico.

A emissão do Decreto trouxe uma importante alteração em relação à Portaria 005. Passase a permitir a conversão total da medida compensatória em obras e serviços, desde que:

[...] mediante decisão fundamentada do Secretário Municipal do Verde e do Meio Ambiente, devendo a instrução processual conter, obrigatoriamente, como referência, orçamento do projeto a ser executado com preços da tabela oficial de custos unitários praticados pela Administração Municipal ou, na sua impossibilidade, orçamento a partir de pesquisa de mercado ${ }^{149}$.

Segundo a SVMA, a adoção de tal medida buscou facilitar o direcionamento de recursos para a construção dos parques lineares previstos no Plano Diretor Estratégico. Retoma-se, desse modo, o mesmo princípio presente na Portaria 136/2003, que permitiu viabilizar a construção de novos parques públicos no município no fim da Gestão Marta Suplicy.

A priorização das compensações ambientais direcionadas para obras e serviços, inicialmente combatida pela Gestão Serra/Kassab, acaba sendo incorporada três anos depois de experiências mal-sucedidas no sentido contrário.

Mais que isso, deve ser levado em conta o contexto de final de mandato, no qual os instrumentos que permitam viabilizar rapidamente obras de visibilidade (tais como parques urbanos), podem tornar-se importantes aliados, do mesmo modo que ocorrera na gestão anterior.

O reconhecimento da eficiência das conversões compensatórias em obras e serviços, aliado ao peso do uso de um Decreto, possivelmente denote que esse pode tornar-se um caminho a ser seguido e não apenas um recurso utilizado oportunamente nos períodos finais de gestões públicas. 
As tabelas 6 e 7 fazem um quadro-resumo contendo os principais aspectos modificados pela legislação de compensações ambientais dos anos de 1987 a 2008. Deve-se ressaltar o efeito cumulativo dos aperfeiçoamentos adquiridos pelo mecanismo ao longo desse período. Na página seguinte, a tabela 8 faz a contextualização das compensações ambientais paulistanas em relação às principais gestões e legislações pertinentes no Brasil.

Tabela 6. Critérios utilizados

para compensação ambiental

arbórea na cidade de São Paulo
1

Portaria $10365 / 87$
DAP

Tipo de remoção (corte ou transplante)

Local da compensação (interna ou externa ao terreno)

Árvores raras ou de especial interesse

Fórmula para cálculo da

conversão da modalidade

Fórmula para cálculo da compensação

em áreas impermeáveis

Fator de correção para os

$10 \%$ com maiores DAPs

Variação das espécies no lote de

mudas entregues ao DEPAVE

Origem da espécie (nativa ou exótica)

Valoração ecológica

\begin{tabular}{|c|c|c|c|c|c|}
\hline- & 3 classes & 7 classes & 7 classes & 7 classes & 7 classes \\
\hline- & $x$ & $x$ & $x$ & $x$ & $x$ \\
\hline- & $x$ & $x$ & $x$ & $x$ & $x$ \\
\hline- & - & $x$ & $x$ & $x$ & $x$ \\
\hline- & - & $x$ & $x$ & $x$ & $x$ \\
\hline- & - & - & $x$ & $x$ & $x$ \\
\hline- & - & - & - & $x$ & $x$ \\
\hline- & - & - & - & $x$ & $x$ \\
\hline
\end{tabular}

Tabela 7. Exceções estabelecidas pela legislação de compensação ambiental arbórea na cidade de São Paulo

\begin{tabular}{|l|c|}
\hline $\begin{array}{l}\text { Habitação de Interesse Social } \\
\text { (redução de até 50\%) }\end{array}$ & $\begin{array}{c}\text { Port } \\
136 / 2003\end{array}$ \\
\hline Corte irregular (aumento de até 30\%) & $\begin{array}{c}\text { Port } \\
136 / 2003\end{array}$ \\
\hline $\begin{array}{l}\text { Árvores de especial interesse } \\
\text { (aumento do fator) }\end{array}$ & $\begin{array}{c}\text { Port } \\
136 / 2003\end{array}$ \\
\hline $\begin{array}{l}\text { Multa pelo descumprimento } \\
\text { de obrigações }\end{array}$ & $\begin{array}{c}\text { Port } \\
136 / 2003\end{array}$ \\
\hline $\begin{array}{l}\text { Habitação do Mercado Popular } \\
\text { (redução de até 50\%) }\end{array}$ & $\begin{array}{c}\text { Port } \\
005 / 2006\end{array}$ \\
\hline $\begin{array}{l}\text { Vegetação exótica (redução } \\
\text { de até 50\%) }\end{array}$ & $\begin{array}{c}\text { Port } \\
005 / 2006\end{array}$ \\
\hline $\begin{array}{l}\text { Mudas com DAP maior que o } \\
\text { exigido (redução da quantia) }\end{array}$ & $\begin{array}{c}\text { Port } \\
005 / 2006\end{array}$ \\
\hline
\end{tabular}


Tabela 8. Quadro cronológico da

legislação de compensação ambiental paulistana

\begin{tabular}{|c|c|c|c|c|c|c|c|c|c|c|c|c|}
\hline & & 1986 & 1987 & 1988 & 1989 & 1990 & 1991 & 1992 & 1993 & 1994 & 1995 & 1996 \\
\hline \multirow{3}{*}{ Gestão } & Federal & \multicolumn{4}{|c|}{ José Sarney (PFL) } & \multicolumn{2}{|c|}{ Fernando Collor (PRN) } & \multicolumn{3}{|c|}{ Itamar Franco } & \multicolumn{2}{|c|}{$\begin{array}{c}\text { Fernando Henrique } \\
\text { Cardoso (PSDB) }\end{array}$} \\
\hline & Estadual & $\begin{array}{l}\text { Franco } \\
\text { Montoro }\end{array}$ & \multicolumn{4}{|c|}{ Orestes Quércia (PMDB) } & \multicolumn{4}{|c|}{ Luís Fleury (PMDB) } & \multicolumn{2}{|c|}{ Mário Covas (PSDB) } \\
\hline & Municipal & \multicolumn{3}{|c|}{ Jânio Quadros (PTB) } & \multicolumn{4}{|c|}{ Luiza Erundina (PT) } & \multicolumn{4}{|c|}{ Paulo Maluf (PTB) } \\
\hline \multirow{3}{*}{ Legislação } & Federal & $\begin{array}{c}\text { Resolução } \\
\text { Conama } \\
001\end{array}$ & $\begin{array}{c}\text { Resolução } \\
\text { Conama } \\
010\end{array}$ & Constituição & & & & & & & & \\
\hline & Estadual & $\begin{array}{l}\text { Criação da } \\
\text { SMA }\end{array}$ & & & $\begin{array}{l}\text { Decreto } \\
30.433\end{array}$ & & & & & $\begin{array}{l}\text { Decreto } \\
39.743\end{array}$ & & \\
\hline & Municipal & & Lei 10.365 & & & & & & $\begin{array}{l}\text { Criação } \\
\text { SVMA }\end{array}$ & & & \\
\hline
\end{tabular}




\begin{tabular}{|c|c|c|c|c|c|c|c|c|c|c|c|}
\hline 1997 & 1998 & 1999 & 2000 & 2001 & 2002 & 2003 & 2004 & 2005 & 2006 & 2007 & 2008 \\
\hline \multicolumn{6}{|c|}{ Fernando Henrique Cardoso (PSDB) } & \multicolumn{6}{|c|}{ Luís Inácio Lula da Silva (PT) } \\
\hline \multicolumn{4}{|c|}{ Mário Covas (PSDB) } & \multicolumn{5}{|c|}{ Geraldo Alckmin (PSDB) } & $\begin{array}{l}\text { Cláudio Lembo } \\
\text { (PFL) }\end{array}$ & \multicolumn{2}{|c|}{ José Serra (PSDB) } \\
\hline \multicolumn{4}{|c|}{ Celso Pitta (PTB) } & \multicolumn{4}{|c|}{ Marta Suplicy (PT) } & $\begin{array}{l}\text { José Serra } \\
\text { (PSDB) }\end{array}$ & \multicolumn{3}{|c|}{ Gilberto Kassab (DEM) } \\
\hline & \multicolumn{2}{|c|}{ Lei de Crimes Ambientais } & Lei 9.985 & & & & $\begin{array}{l}\text { Câmara de } \\
\text { Compensação }\end{array}$ & & $\begin{array}{l}\text { Lei da Mata } \\
\text { Atlântica }\end{array}$ & & \\
\hline & & & & $\begin{array}{l}\text { Resolução } \\
\text { SMA } 16\end{array}$ & & & & $\begin{array}{l}\text { Câmara de } \\
\text { Compensação }\end{array}$ & & & \\
\hline & $\begin{array}{c}\text { Memorando } \\
\text { DEPAVE } 41\end{array}$ & $\begin{array}{c}\text { Portaria } \\
\text { SVMA } \\
088\end{array}$ & & $\begin{array}{l}\text { Portaria } \\
\text { SVMA } 122\end{array}$ & $\begin{array}{c}\text { Plano } \\
\text { Diretor } \\
\text { Estratégico }\end{array}$ & $\begin{array}{c}\text { Portaria SVMA } \\
136\end{array}$ & $\begin{array}{l}\text { Portaria } \\
\text { SVMA } 26\end{array}$ & $\begin{array}{c}\text { Portaria SVMA } \\
\text { 009/ Câmara de } \\
\text { Compensação } \\
\text { Ambiental }\end{array}$ & $\begin{array}{c}\text { Portaria SVMA } \\
\text { 005/ Decreto } \\
47.145\end{array}$ & & \\
\hline
\end{tabular}




\section{Compensações ambientais arbóreas em outras capitais do Brasil}

A comparação do mecanismo compensatório paulistano em relação àqueles aplicados em outras cidades do país contribui na análise dos seus aspectos positivos e deficitários. Permite também constatar experiências bem sucedidas que podem ser utilizadas na cidade de São Paulo.

Foram escolhidas duas cidades para a comparação: Rio de Janeiro e Porto Alegre. A escolha se deve ao fato desses dois municípios possuírem legislações compensatórias com nível de detalhamento e qualidade iguais ou até superiores ao paulistano. Além disso, o município do Rio de Janeiro é a capital brasileira com porte e problemáticas mais semelhantes à cidade de São Paulo ${ }^{150}$.

$\mathrm{Na}$ cidade do Rio de Janeiro, as compensações ambientais arbóreas são denominadas Medidas Compensatórias (MC), sendo aplicadas conjuntamente pela Secretaria Municipal de Meio Ambiente (SMAC) e pela Unidade de Parques e Jardins do Município (UPJ).

Desde 1990, a lei orgânica da Cidade do Rio de Janeiro já previa a necessidade de compensações ambientais pela retirada de árvores, quando cita que "Os serviços de derrubada de árvores somente poderão ser efetuados mediante prévia autorização do órgão ambiental e sob sua orientação." ${ }^{151}$

Em 2008, o texto mais atualizado sobre o assunto na cidade do Rio de Janeiro é a resolução SMAC 345/2004. A última atualização da legislação carioca ocorreu, portanto, três anos antes da legislação mais recente em São Paulo (2007). Tal fato não representa necessariamente uma defasagem, pois vários princípios presentes na legislação do Rio de Janeiro foram incorporados em São Paulo pela portaria SVMA 009/2005.

O principal deles é a introdução de fatores de valoração ecológica, por meio da utilização com 10.886.518 hab e área de $1.523 \mathrm{~km}$.

151. Lei orgânica da Cidade do Rio de Janeiro. Art. 477. Promulgada em 05 de Abril de 1990.

situação específica. 
Outro elemento utilizado pela legislação paulistana é a listagem de modalidades compensatórias alternativas, praticamente idêntica nas duas cidades. Também é comum aos dois municípios o uso da micro-bacia hidrográfica como critério para delimitação da área prioritária a serem aplicadas as compensações externas ao empreendimento.

Com relação às diferenças da legislação compensatória paulistana e carioca, pode-se citar a definição de indivíduo arbóreo. A resolução SMAC 345/2004 estabelece não só o conceito de árvore, como também de arbustos e herbáceas. Além disso, a definição de árvores na legislação carioca ${ }^{152}$ difere da paulistana, pois utiliza como critério "toda planta lenhosa que, quando adulta, tenha altura mínima de três metros e apresente divisão nítida entre copa, tronco e/ou estipe ${ }^{153}$.” Em São Paulo, o critério utilizado é mais facilmente determinável, pois se baseia no Diâmetro à Altura do Peito (DAP).

Outra diferença é o fato da legislação carioca especificar o plantio compensatório "preferencialmente, com espécies nativas adequadas ao ecossistema local da implantação, devendo ser justificado, no respectivo processo administrativo, os casos em que for necessário adotar espécies exóticas." ${ }^{154}$. Em São Paulo, o uso de vegetação nativa é obrigatório e definido por uma listagem específica, presente no Manual de Arborização do município ${ }^{155}$.

Por um lado, a especificação exclusiva de espécies nativas mostra um comprometimento da legislação paulistana com a (vasta) biodiversidade nacional. Por outro lado, pode ocasionar dificuldades para a obtenção de mudas compensatórias, pois os viveiristas costumam trabalhar com as espécies mais solicitadas pelo mercado que, infelizmente, é constituída em grande parte por vegetação exótica. A opção da legislação carioca provavelmente baseia-se nesse princípio.

$\mathrm{Na}$ cidade de Porto Alegre, os procedimentos para compensações ambientais arbóreas são definidos, no ano de 2008, pelo Decreto Municipal no 15.418/2006. O instrumento utilizado no município é denominado Termo de Compensação Vegetal (TCV).A legislação local apresenta diversas diferenças em relação à paulistana.
152. Resolução SMAC 345/2004. Art. 3 item IV

153. "Estipe - Caule normalmente ereto e mais ou menos cilíndrico, não ramificado, onde as folhas concentram-se apenas no ápice. O termo é especialmente usado para caules de palmeiras" GONÇALVES, E. G; LORENZI, H. Morfologia Vegetal: Organografia e dicionário ilustrado de morfologia das plantas vasculares. São Paulo: Instituto Plantarum de Estudos da Flora,
2007. p. 206

154. Idem. Art. 15

155. Manual Técnico de Arborização DEPAVE, 1999. 
156. A legislação paulistana - por meio do Decreto Municipal 47.145/2006 - prevê este quesito de forma implícita, ao considerar a "importância para a fauna" como fator de valoração

157. Decreto Municipal no 15.418/2006. Cap. VIII

158. Segundo dados do IBGE, Porto Alegre possuía 1.420.667 hab e área de $497 \mathrm{~km}$ em 2007. Nesse mesmo período, São Paulo contava com 10.886 .518 hab e área de $1.523 \mathrm{~km}$.
A primeira delas é o fato do mecanismo gaúcho conferir destaque e um extenso detalhamento de elementos menos trabalhados em São Paulo, como o transplante e a poda. Nos transplantes, exige-se inclusive que o empreendedor faça uma apólice de seguro para cobertura no caso de não cumprimento adequado da legislação.

Nota-se também um grau de exigência muito maior em diversos aspectos. O texto prevê refinamentos tais como o tratamento diferenciado das árvores que possuam ninhos de pássaros $^{156}$.

Outra sofisticação consiste em obrigar o empreendedor a divulgar para a comunidade do entorno, com antecedência de 10 dias, quais árvores serão retiradas ou podadas pelo empreendedor por meio de placa informativa, publicação em jornal ou panfletagem em um raio de até $200 \mathrm{~m}$ da obra ${ }^{157}$.

Tal grau de exigência só é possível devido a características propícias existentes no município de Porto Alegre. A Secretaria Municipal do Meio Ambiente (SMAM), responsável pela aplicação das compensações ambientais na cidade, é a mais antiga do país, atuando desde o ano de 1976. Sua estrutura é mais consolidada e a experiência é bem maior que a paulistana (que surgiu em 1993). Além disso, a cidade possui um porte consideravelmente menor ${ }^{158}$. Essa condição facilita a atuação fiscalizadora do poder público.

Apesar das características anteriormente citadas serem dificilmente aplicáveis a cidades com o porte e a falta de organização adequada existente na cidade de São Paulo, outras peculiaridades da legislação gaúcha mostram-se viáveis.

O texto da legislação incentiva empreendimentos que utilizem técnicas construtivas ecologicamente adequadas. De acordo com o mecanismo, possibilita-se uma redução de até $50 \%$ da quantidade de árvores a compensar, caso a obra utilize simultaneamente duas das seguintes técnicas: madeira certificada, reutilização de água de chuva ou abastecimento por energia solar (mínimo de 30\%).

A legislação gaúcha também prioriza a utilização de medidas preventivas e mitigadoras do dano causado pela retirada de árvores. Seu artigo 23, por exemplo, prevê uma redução de 
até 50\% na quantia compensatória restante, caso o empreendedor desista de cortar metade das árvores autorizadas pela $\mathrm{SMAM}^{159}$.

Além disso, o próprio grau de rigor exigido pela legislação já atua como desincentivo ao corte de árvores.

Outro ponto aproveitável para o caso paulistano é a contextualização das medidas compensatórias dentro do processo de licenciamento ambiental ${ }^{160}$.

Porto alegre também possui alguns critérios mais adequados para a valoração de espécies exóticas. Ao invés de estabelecer proporção compensatória de 1:1 para eucaliptos e pinus, a legislação gaúcha estipula que "A compensação vegetal de que trata este Decreto poderá ser reduzida em relações às espécies exóticas invasoras, devendo esta decisão ser fundamentada" ${ }^{161}$ A legislação não especifica, no entanto (ao menos no decreto), qual será a quantia estipulada, quem fará essa análise e quando essas exceções serão abertas. Nesse sentido, a legislação paulistana possui um grau de detalhamento superior, dando menos margem a dubiedades interpretativas.

Apesar de apresentar diversos aspectos exemplares, a legislação gaúcha também apresenta algumas defasagens em relação à paulistana. É o caso da quantia de mudas previstas para compensação, cuja proporção máxima estipulada é 15:1 (contra 45:1 na cidade de São Paulo). As especificações do porte da muda compensatória na legislação de Porto Alegre são menos claras que a paulistana, citando um "diâmetro do caule proporcional à altura total da muda e de acordo com as características da espécie a que pertence" ${ }^{162}$, sem fornecer um valor exato, como ocorre em São Paulo (DAP varia de 3 a $7 \mathrm{~cm}$ ).
159. No mesmo artigo, excetuam-se os casos de árvores exóticas, árvores em áreas não construídas ou imunes a corte pela legislação local.

160. “Em obras ou atividades sujeitas ao procedimento de licenciamento ambiental municipal, a compensação vegetal tratada neste Decreto poderá ser definida em critérios próprios na competente licença" Decreto Municipal no $15.418 / 2006$, artigo 6

161. Decreto Municipal № 15.418/2006. Art. 35

162. Decreto Municipal no $15.418 / 2006$. Anexo II 
A seguir, uma comparação das principais características da legislação de compensação de cada município abordado:

Tabela 9. Quadro comparativo entre os mecanismos de

compensação ambiental arbórea em São Paulo, Rio de Janeiro e Porto Alegre.

São Paulo

Rio de Janeiro

Porto Alegre

\begin{tabular}{|c|c|c|c|}
\hline nome do mecanismo & Termo de Compromisso Ambiental & Medida Compensatória & Termo de Compensação Vegetal \\
\hline definição árvore & DAP $>5 \mathrm{~cm} /$ altura $1,30 \mathrm{~m}$ & altura $>3 m$ & altura $>2 m$ \\
\hline $\begin{array}{l}\text { proporção compensatória } \\
\text { mínima }\end{array}$ & $1: 1$ & $3: 1$ & $1: 1$ \\
\hline $\begin{array}{c}\text { proporção compensatória } \\
\text { máxima }\end{array}$ & $45: 1^{*}$ & $20: 1$ & $15: 1$ \\
\hline $\begin{array}{c}\text { caso para compensação } \\
\text { máxima }\end{array}$ & nativa $\mathrm{DAP}>150 \mathrm{~cm}$ & nativa $\mathrm{DAP}>50 \mathrm{~cm}$ & nativa porte $>10 \mathrm{~m}$ \\
\hline critério compensação & DAP + valoração ecológica + localização & $\begin{array}{c}\text { DAP + valoração } \\
\text { ecológica+localização }\end{array}$ & Porte \\
\hline qtde mínima plantio** & =quantidade de árvores retiradas & $25 \%$ & - \\
\hline$\%$ máxima obras civis & $100 \%$ & $50 \%$ & $100 \%$ \\
\hline $\begin{array}{l}\text { casos de redução da } \\
\text { quantia compensatória }\end{array}$ & $\begin{array}{l}\text { Habitações populares, espécies } \\
\text { exóticas, plantio em } 100 \% \text { da área } \\
\text { permeável e fornecimento de mudas } \\
\text { com porte acima do solicitado }\end{array}$ & - & $\begin{array}{l}\text { Espécies exóticas (invasoras), } \\
\text { uso de tecnologias ecológicas no } \\
\text { empreendimento, desistência nos } \\
\text { cortes previstos }\end{array}$ \\
\hline $\begin{array}{l}\text { modalidades } \\
\text { compensatórias } \\
\text { alternativas }\end{array}$ & $\begin{array}{l}\text { doação de mudas, obras e serviços, } \\
\text { educação ambiental, projeto, } \\
\text { levantamento, aquisição de terreno }\end{array}$ & $\begin{array}{c}\text { doação de mudas, obras } \\
\text { e serviços, educação } \\
\text { ambiental }\end{array}$ & $\begin{array}{l}\text { doação de mudas, obras e serviços, } \\
\text { educação ambiental, verba para fundo } \\
\text { específico, manejo arbóreo em área } \\
\text { pública }\end{array}$ \\
\hline prazo de execução & 6 meses (prorrogáveis) & 60 dias a 12 meses & 12 a 36 meses \\
\hline
\end{tabular}

* sujeita a fatores multiplicadores

**porcentagem da quantia total de mudas compensatórias 


\section{Mapeamento das Ações}

Ao longo de dez anos de aplicação oficial na cidade de São Paulo (1998 a 2008), as compensações ambientais foram responsáveis por uma quantidade considerável de ações relacionadas sobretudo à arborização urbana e à produção de espaços livres públicos.

As informações analisadas foram obtidas a partir do banco de dados disponibilizado pela Câmara de Compensação Ambiental da Secretaria do Verde e Meio Ambiente (CCA / SVMA) no ano de 2007.

O período utilizado para a maioria das análises corresponde a um recorte de dois anos e meio, entre janeiro de 2005 e julho de 2007. Tal fato se deve à insuficiência de informações disponíveis para os anos anteriores (1998-2004), quando a sistematização de dados pela SVMA ainda não era consistente. Essa amostragem, no entanto, é bastante representativa da produção realizada, até mesmo porque antes dessa época o mecanismo estava em processo de consolidação no município. Além disso, esse período delimita a produção de uma Gestão Pública específica no município (Serra/Kassab) e representa os resultados práticos de duas alterações significativas da legislação compensatória - as Portarias SVMA 009/2005 e 005/2006.

A unidade de medida usada para todas as comparações foi a quantidade de mudas geradas pelos empreendimentos. Tal parâmetro, também adotado pela SVMA, foi utilizado tanto para as medidas compensatórias que resultam em plantio quanto para as conversões (obras e serviços, educação ambiental, aquisição de novos terrenos). Essas quantidades, naturalmente, não equivalem ao total de árvores retiradas pelos empreendimentos. Elas correspondem à proporção compensatória estabelecida pela SVMA, que variou conforme a legislação vigente na época, e que no ano de 2008 pode chegar a 45 mudas para cada árvore retirada ${ }^{163}$.

Para determinação do valor financeiro correspondente à quantidade de mudas compensatórias, deve-se multiplicá-lo pela quantia estabelecida pela SVMA, atualizada 
mensalmente ${ }^{164}$. Um cálculo simplificado permite afirmar que no período analisado (dois anos e meio), os recursos obtidos com a aplicação das compensações ambientais em São Paulo foram pouco mais de R\$60 milhões (ou US\$34 milhões). Esse total inclui tanto os valores utilizados para plantio quanto para conversões diversas. Cabe frisar, no entanto, que esse quantia não corresponde a uma receita com a qual o Poder Público pode contar regularmente, mas sim a um recurso que atuou de forma auxiliar (embora significativa).

\section{Tipo de compensação}

Do total de compensações realizadas no período avaliado, a maioria corresponde ao plantio de árvores (70\%). Tal proporção reflete a prioridade dada no início da Gestão Serra/Kassab a esse tipo de medida compensatória. Caso o período analisado correspondesse à Gestão Marta Suplicy, possivelmente a quantidade de plantios compensatórios seria menor, devido à prioridade dada naquele momento ao custeio da execução de novos espaços públicos por TCAs. Esse valor não seria, no entanto, inferior a $50 \%$ do total, que corresponde ao mínimo de plantio compensatório estabelecido pela legislação daquela época.

Tabela 10. Comparação das quantias de compensações por plantio e as

conversões em outras modalidades:

\begin{tabular}{|l|c|c|}
\hline tipo de compensação & qtde & \% \\
\hline Plantio (interno e externo) & 160.018 & $\mathbf{7 0}$ \\
\hline Conversão & 67.871 & $\mathbf{3 0}$ \\
\hline TOTAL & 227.889 & 100 \\
\hline
\end{tabular}

\section{Tipo de empreendedor}

Com relação ao tipo de empreendedor, observa-se que a maioria das compensações é gerada pela iniciativa privada. Essa predominância ocorre tanto nos casos de plantio (85\%) quanto nos casos de conversão da medida compensatória, sendo menor neste último (77\%). 
Caso fosse possível analisar as quantias de TCAs gerados pelo Poder Público na Gestão Marta Suplicy, constataríamos uma proporção inferior à observada na Gestão Serra/ Kassab. De acordo com a CCA, a aplicação indistinta de compensações ambientais ao poder público e privado só foi priorizada a partir da Gestão Serra/Kassab. Na gestão anterior, o Poder Público fazia "vistas grossas" aos danos gerados por ele próprio.

Tabela 11. Total de compensações ambientais na cidade de São Paulo entre os anos de 2005 e 2007, analisado segundo o tipo de empreendedor. Casos de plantio interno e externo ao terreno:

\begin{tabular}{|l|c|c|c|c|c|}
\hline tipo de empreendedor & $\mathbf{2 0 0 5}$ & $\mathbf{2 0 0 6}$ & $\mathbf{2 0 0 7}$ & TOTAL & \% \\
\hline privado & 23.507 & 88.474 & 23.477 & 135.458 & $\mathbf{8 5}$ \\
\hline público & 6.080 & 10.001 & 8.479 & 24.560 & $\mathbf{1 5}$ \\
\hline TOTAL & 29.587 & 98.475 & 31.956 & 160.018 & $\mathbf{1 0 0}$ \\
\hline
\end{tabular}

Tabela 12. Total de compensações ambientais na cidade de São Paulo entre os anos de 2005 e 2007, analisado segundo o tipo de empreendedor. Casos de conversão da medida compensatória:

\begin{tabular}{|l|c|c|c|c|c|}
\hline tipo de empreendedor & $\mathbf{2 0 0 5}$ & $\mathbf{2 0 0 6}$ & $\mathbf{2 0 0 7}$ & TOTAL & $\mathbf{\%}$ \\
\hline privado & 19.423 & 24.911 & 8.220 & 52.554 & $\mathbf{7 7}$ \\
\hline público & - & 12.856 & 2.461 & 15.317 & $\mathbf{2 3}$ \\
\hline TOTAL & 19.423 & 37.767 & 10.681 & 67.871 & $\mathbf{1 0 0}$ \\
\hline
\end{tabular}

\section{Tipo de conversão}

Como o foco deste trabalho concentra-se nas medidas compensatórias alternativas ao plantio (sobretudo a produção de novos espaços livres), estas foram subdivididas por tipo. As conversões de medidas compensatórias possíveis até o ano de 2008 são: obras e serviços em espaços livres públicos municipais, projetos de educação ambiental, aquisição de novos terrenos e o custeio de projetos paisagísticos e levantamentos planialtimétricos. 
Tabela 13. Quantidades de compensações ambientais convertidas em outras modalidades compensatórias entre 2005 e 2007.

\begin{tabular}{|l|c|c|c|c|c|}
\hline tipo & $\mathbf{2 0 0 5}$ & $\mathbf{2 0 0 6}$ & $\mathbf{2 0 0 7}$ & \multicolumn{1}{c|}{ TOTAL } & \% \\
\hline obra e serviços & 18.807 & 16.106 & 7.225 & 42.138 & $\mathbf{6 2}$ \\
\hline aquisição de área verde pública* & - & 17.272 & - & 17.272 & $\mathbf{2 5}$ \\
\hline $\begin{array}{l}\text { projeto / levantamentos } \\
\text { para espaços livres públicos }\end{array}$ & 464 & 3.906 & 3.365 & 7.735 & $\mathbf{1 1}$ \\
\hline educação ambiental & 152 & 483 & 91 & 726 & $\mathbf{1}$ \\
\hline TOTAL & 19.423 & 37.767 & 10.681 & 67.871 & $\mathbf{1 0 0}$ \\
\hline
\end{tabular}

* processo não finalizado até 2008

A maior parte dos valores convertidos corresponde a obras e serviços (62\%). Essa proporção evidencia a prioridade estabelecida pela SVMA ao custeio de novos espaços livres públicos no município, no período analisado. Convertendo essa quantia em valor financeiro, temse quase $R \$ 11.300 .000,00$ (ou cerca de US\$6.400.000,00 segundo a cotação média do câmbio em fevereiro de 2008).

\section{Tipologia do empreendimento}

Para a análise da tipologia do empreendimento, subdividiu-se as compensações em duas categorias: plantio e conversões. Em ambas as categorias, há predominância dos empreendimentos privados. Juntas, as torres residenciais e os estabelecimentos comerciais correspondem a 78\% do total de mudas obtidas por compensações no município no período analisado. Essa proporção reflete uma previsível predominância de empreendimentos privados na cidade. Nos casos de conversão, a parcela representada pelas torres residenciais e pelos estabelecimentos comerciais é um pouco menor, mas ainda predominante (73\% do total). Tal fato se deve à maior representatividade dos empreendimentos públicos de infra-estrutura (tais como obras viárias e canalizações de córrego), que correspondem a $17,5 \%$ do total. 
Tabela 14. Tipologias que mais geram

compensações por plantio (interno e externo) no município

\begin{tabular}{|l|c|c|c|c|c|}
\hline \multicolumn{1}{|c}{$\mathbf{2}$ tipologia } & $\mathbf{2 0 0 5}$ & $\mathbf{2 0 0 6}$ & $\mathbf{2 0 0 7}$ & \multicolumn{1}{c|}{ TOTAL } & \% \\
\hline torre residencial & 19.584 & 70.578 & 17.649 & 107.811 & $\mathbf{6 7 , 4}$ \\
\hline comercial & 2.056 & 13.811 & 883 & 16.750 & $\mathbf{1 0 , 5}$ \\
\hline residência unifamiliar & 1.349 & 3.877 & 4.990 & 10.216 & $\mathbf{6 , 4}$ \\
\hline transporte público & 234 & 3.936 & 3.016 & 7.186 & $\mathbf{4 , 5}$ \\
\hline obras diversas (público) & 1.880 & 1.759 & 4.619 & 8.258 & $\mathbf{5 , 2}$ \\
\hline infra-estrutura (público) & 3.590 & 1.958 & 240 & 5.788 & $\mathbf{3 , 6}$ \\
\hline educacional (público) & 376 & 1.797 & 424 & 2.597 & $\mathbf{1 , 6}$ \\
\hline industrial & 518 & - & - & 518 & $\mathbf{0 , 3}$ \\
\hline obras diversas (privado) & - & 501 & - & 501 & $\mathbf{0 , 3}$ \\
\hline hospital (público) & - & 50 & 180 & 230 & $\mathbf{0 , 1}$ \\
\hline educacional (privado) & - & 208 & - & 208 & $\mathbf{0 , 1}$ \\
\hline TOTAL & 29.587 & 98.475 & 31.956 & 160.018 & $\mathbf{1 0 0}$ \\
\hline
\end{tabular}

Tabela 15. Tipologias que mais geram compensações por conversão de medida compensatória no município

\begin{tabular}{|l|c|c|c|c|c|}
\hline tipologia & $\mathbf{2 0 0 5}$ & $\mathbf{2 0 0 6}$ & $\mathbf{2 0 0 7}$ & \multicolumn{1}{c|}{ TOTAL } & $\%$ \\
\hline torre residencial & 8.602 & 19.505 & 6.368 & 34.475 & $\mathbf{5 0 , 8}$ \\
\hline comercial & 10.552 & 4.181 & 264 & 14.997 & $\mathbf{2 2 , 1}$ \\
\hline infra-estrutura (público) & - & 10.379 & 1.531 & 11.910 & $\mathbf{1 7 , 5}$ \\
\hline transporte público & - & 2.477 & - & 2.477 & $\mathbf{3 , 6}$ \\
\hline residência unifamiliar & 141 & 610 & 1.588 & 2.339 & $\mathbf{3 , 4}$ \\
\hline obras diversas (público) & - & - & 930 & 930 & $\mathbf{1 , 4}$ \\
\hline educacional (privado) & - & 615 & - & 615 & $\mathbf{0 , 9}$ \\
\hline industrial & 128 & - & - & 128 & $\mathbf{0 , 2}$ \\
\hline TOTAL & 19.423 & 37.767 & 10.681 & 67.871 & $\mathbf{1 0 0}$ \\
\hline
\end{tabular}




\section{Local de origem das compensações}

Para esta análise, foi possível utilizar uma base de dados mais extensa, visto que a SVMA possui informações sistematizadas desde o ano de 1998. A delimitação espacial adotada é a Subprefeitura. Os dados foram divididos em três categorias: plantio interno, plantio externo e conversões. Tal subdivisão permite comparar quais Subprefeituras da cidade geram mais arborização ou formas compensatórias alternativas.

Com relação ao plantio dentro do próprio lote, a maior parte das compensações concentrase na Subprefeitura de Pirituba-Jaraguá (44\% do total), bairro com menor poder aquisitivo, mas com quantidade significativa de novos empreendimentos. Nas situações de plantio externo ao lote, a situação muda. A predominância passa a ser de Subprefeituras em áreas de maior poder aquisitivo. Além disso, a contribuição de cada local é mais equilibrada, subdividindo-se entre Butantã (18\%), Santo Amaro (16\%) e Campo Limpo (13\%). Todas essas Subprefeituras possuem número elevado de novos empreendimentos do setor residencia ${ }^{165}$. Butantã abriga o distrito do Morumbi e o bairro de Vila São Francisco, que têm produzido, até o ano de 2008, grande quantidade empreendimentos (sobretudo torres e vilas residenciais). A mesma situação ocorre com o bairro de Alto da Boa Vista, pertencente à Subprefeitura de Santo Amaro. A subprefeitura de Campo Limpo abriga o distrito de Vila Andrade, que possui diversos empreendimentos residenciais resultantes da expansão de seu distrito vizinho, o Morumbi.

As conversões em outras formas de compensação também predominam em bairros de poder aquisitivo mais alto. As três maiores quantidades situam-se nas subprefeituras de Santo Amaro, Butantã e Vila Mariana, novamente em proporções equilibradas (respectivamente 23, 21 e 18\%). Tal fato se deve a estas Subprefeituras concentrarem elevado número de novos empreendimentos do setor imobiliário e estarem sujeitos ao maior controle da fiscalização ambiental. Além disso, são locais com índice mais alto de arborização viária e de logradouros. A saturação da quantidade de árvores nesses locais dificulta a realização de compensações ambientais por plantio no entorno imediato dos novos empreendimentos. As conversões de medida compensatória ocorrem em situações nas quais a realização de plantio arbóreo próximo ao local do dano ambiental é inviável.
165. De acordo com dados da EMBRAESP, todas as Subprefeituras citadas possuem ao menos um Distrito figurando entre as dez primeiras posições no ranking de lançamentos imobiliários entre os anos de 1995 e 2005. 
Tabela 16. Quantidade de mudas compensatórias geradas por Subprefeitura para plantio interno, externo e conversões de medida compensatória

Plantio interno

\begin{tabular}{|l|c|c|}
\hline \multicolumn{1}{|c|}{ Subprefeitura } & qtde & $\%$ \\
\hline Pirituba / Jaraguá & 56577 & 44,32 \\
\hline Campo Limpo & 19402 & 15,20 \\
\hline Capela do Socorro & 9078 & 7,11 \\
\hline Butantã & 7639 & 5,98 \\
\hline São Mateus & 6786 & 5,32 \\
\hline Santo Amaro & 5644 & 4,42 \\
\hline Itaquera & 3864 & 3,03 \\
\hline Pinheiros & 3078 & 2,41 \\
\hline Sé & 2011 & 1,58 \\
\hline Jaçanã Tremembé & 1975 & 1,55 \\
\hline Vila Mariana & 1955 & 1,53 \\
\hline Santana Tucuruvi & 1742 & 1,36 \\
\hline M Boi Mirim & 1460 & 1,14 \\
\hline Fregueria / Brasilândia & 1364 & 1,07 \\
\hline Lapa & 1201 & 0,94 \\
\hline Mooca & 958 & 0,75 \\
\hline Jabaquara & 682 & 0,53 \\
\hline Aricanduva/Vila Formosa & 496 & 0,39 \\
\hline Ipiranga & 480 & 0,38 \\
\hline Cidade Ademar & 370 & 0,29 \\
\hline Casa Verde / Cachoeirinha & 347 & 0,27 \\
\hline Guaianases & 316 & 0,25 \\
\hline Itaim Paulista & 114 & 0,09 \\
\hline Ermelino & 64 & 0,05 \\
\hline Penha & 44 & 0,03 \\
\hline Vila Maria / Vila Guilherme & 3 & 0,00 \\
\hline Perus & 0 & 0,00 \\
\hline TOTAL & 127650 & 100 \\
\hline & & \\
\hline
\end{tabular}

\section{Plantio externo}

\begin{tabular}{|l|c|c|}
\hline \multicolumn{1}{|c|}{ Subprefeitura } & qtde & $\%$ \\
\hline Butantã & 16846 & 18,47 \\
\hline Santo Amaro & 14823 & 16,25 \\
\hline Campo Limpo & 11939 & 13,09 \\
\hline Santana Tucuruvi & 8713 & 9,55 \\
\hline Vila Mariana & 6511 & 7,14 \\
\hline Pinheiros & 6317 & 6,93 \\
\hline Jaçanã Tremembé & 5296 & 5,81 \\
\hline Sé & 3199 & 3,51 \\
\hline Pirituba / Jaraguá & 2649 & 2,90 \\
\hline Lapa & 2439 & 2,67 \\
\hline M Boi Mirim & 2271 & 2,49 \\
\hline Fregueria / Brasilândia & 2204 & 2,42 \\
\hline Perus & 1559 & 1,71 \\
\hline Itaquera & 1287 & 1,41 \\
\hline Vila Maria / Vila Guilherme & 1191 & 1,31 \\
\hline Cidade Ademar & 861 & 0,94 \\
\hline Casa Verde / Cachoeirinha & 667 & 0,73 \\
\hline Capela do Socorro & 569 & 0,62 \\
\hline Ipiranga & 475 & 0,52 \\
\hline Aricanduva/Vila Formosa & 346 & 0,38 \\
\hline Jabaquara & 289 & 0,32 \\
\hline Penha & 269 & 0,29 \\
\hline São Mateus & 218 & 0,24 \\
\hline Mooca & 151 & 0,17 \\
\hline Ermelino & 116 & 0,13 \\
\hline Guaianases & 0 & 0,00 \\
\hline Itaim Paulista & 0 & 0,00 \\
\hline TOTAL & 91205 & 100,00 \\
\hline
\end{tabular}

\section{Conversões}

\begin{tabular}{|l|c|c|}
\hline \multicolumn{1}{|c|}{ Subprefeitura } & qtde & $\%$ \\
\hline Santo Amaro & 38175 & 23,62 \\
\hline Butantã & 34495 & 21,34 \\
\hline Vila Mariana & 29580 & 18,30 \\
\hline Itaquera & 10600 & 6,56 \\
\hline Guaianases & 10379 & 6,42 \\
\hline Pinheiros & 5614 & 3,47 \\
\hline Campo Limpo & 5107 & 3,16 \\
\hline Santana Tucuruvi & 4264 & 2,64 \\
\hline Sé & 4102 & 2,54 \\
\hline Aricanduva/Vila Formosa & 3920 & 2,43 \\
\hline Pirituba / Jaraguá & 2573 & 1,59 \\
\hline Casa Verde / Cachoeirinha & 2273 & 1,41 \\
\hline Lapa & 2247 & 1,39 \\
\hline Mooca & 1490 & 0,92 \\
\hline Itaim Paulista & 1326 & 0,82 \\
\hline Jaçanã Tremembé & 1306 & 0,81 \\
\hline Capela do Socorro & 1277 & 0,79 \\
\hline Jabaquara & 1177 & 0,73 \\
\hline São Mateus & 801 & 0,50 \\
\hline Cidade Ademar & 351 & 0,22 \\
\hline Ipiranga & 315 & 0,19 \\
\hline Fregueria / Brasilândia & 246 & 0,15 \\
\hline Ermelino & 26 & 0,02 \\
\hline M Boi Mirim & 0 & 0,00 \\
\hline Penha & 0 & 0,00 \\
\hline Perus & 0 & 0,00 \\
\hline Vila Maria / Vila Guilherme & 0 & 0,00 \\
\hline TOTAL & 161644 & 100,00 \\
\hline & & \\
\hline
\end{tabular}




\section{Estudos de caso - Espaços livres públicos gerados por compensações ambientais na cidade de São Paulo}

A produção de espaços livres públicos viabilizados por compensações ambientais constitui o foco destes estudos de caso. Todos os parques e praças analisados possuem como ponto comum o fato de serem espaços livres públicos urbanos com algum tipo de equipamento para atividades recreativas (playgrounds, áreas para ginástica, bancos, pisos processados) ou suporte a estas (edificações diversas).

Os casos de arborização urbana gerada por compensações ambientais não serão estudados em detalhe neste trabalho, embora - como foi visto anteriormente - esse tipo de intervenção constitua a maioria dos casos existentes. A extensão desse tema faz com que ele mereça uma pesquisa à parte, que até o ano de 2008 ainda não foi realizada.

Como amostragem de compensações ambientais por meio de arborização urbana, será analisado o projeto do Hospital Alemão Oswaldo Cruz. A obra constitui uma ação especial dentro do universo representado pelas compensações ambientais paulistanas, devido à série de cuidados excepcionais tomados no decorrer da obra. O longo tempo de desenvolvimento do projeto e execução fez com que este caso acompanhasse a evolução da legislação no município, exemplificando diversas questões analisadas neste trabalho.

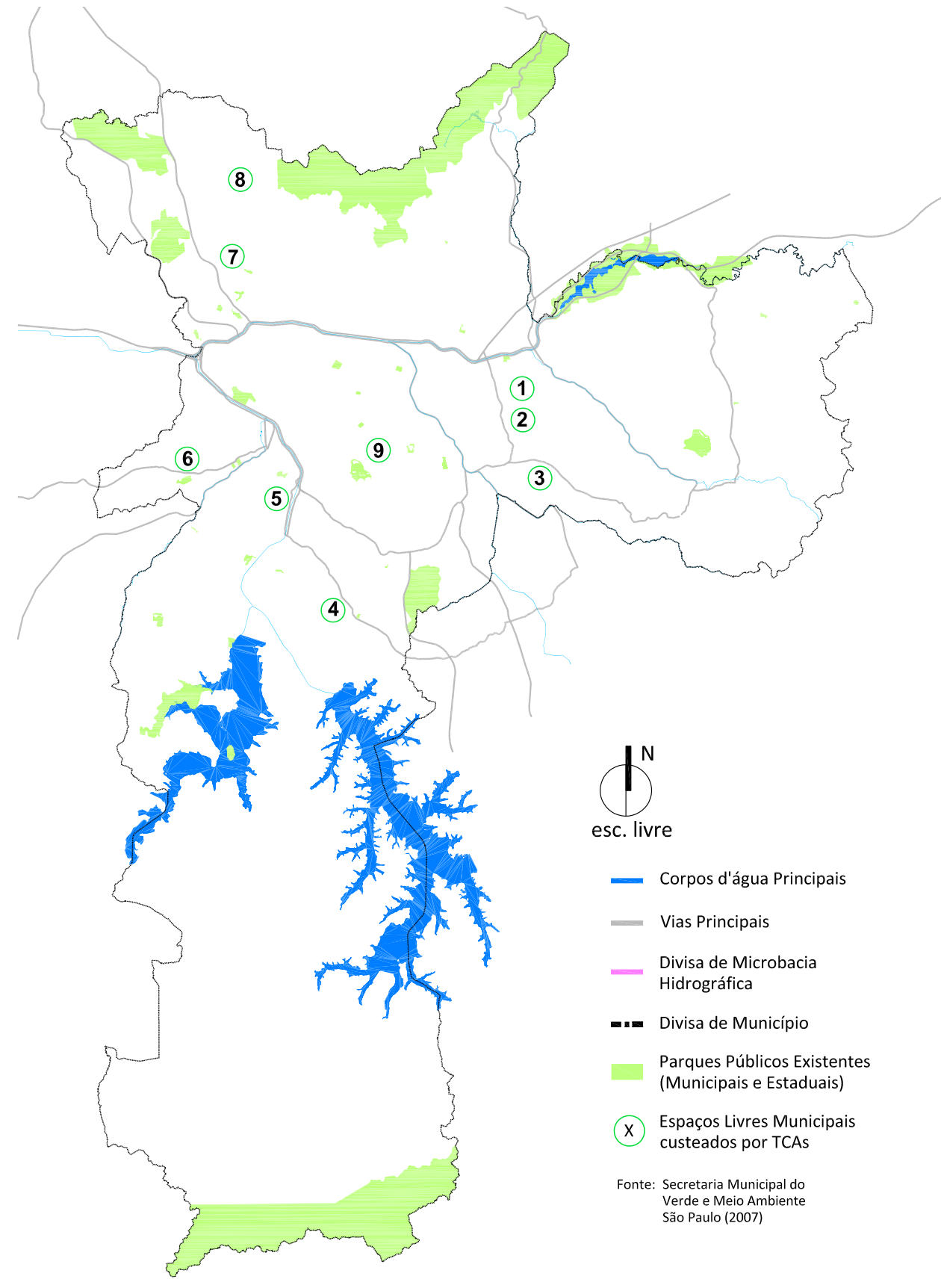


Tabela 17. Espaços Livres custeados por compensações ambientais arbóreas entre os anos de 1998 e 2008

\begin{tabular}{|c|c|c|c|c|c|c|c|c|}
\hline Logradouro & $\begin{array}{l}\text { Praça Silvio } \\
\text { Romero }\end{array}$ & $\begin{array}{l}\text { Praça Anna } \\
\text { dos Santos } \\
\text { Figueiredo }\end{array}$ & $\begin{array}{l}\text { Parque da Vila } \\
\text { Prudente }\end{array}$ & $\begin{array}{l}\text { Parque do } \\
\text { Cordeiro }\end{array}$ & $\begin{array}{l}\text { Praça Nandina } \\
\text { Haddad Ambuda }\end{array}$ & $\begin{array}{l}\text { Parque Linear do } \\
\text { Sapé }\end{array}$ & $\begin{array}{l}\text { Parque Jacintho } \\
\text { Alberto }\end{array}$ & $\begin{array}{c}\text { Parque } \\
\text { Pinheirinho } \\
\text { D’Água }\end{array}$ \\
\hline Localização & 1 & 2 & 3 & 4 & 5 & 6 & 7 & 8 \\
\hline Entrega & 2005 & 2004 & 2004 & 2007 & 2001 & 2007 & 2008 & 2005 \\
\hline Autor & $\begin{array}{c}\text { Raul Pereira } \\
\text { Arquitetos } \\
\text { Associados }\end{array}$ & $\begin{array}{c}\text { Kruchin } \\
\text { Arquitetura }\end{array}$ & DEPAVE & $\begin{array}{l}\text { Raul Pereira } \\
\text { Arquitetos } \\
\text { Associados }\end{array}$ & Gobbi Paisagismo & Solo Ambiente & $\begin{array}{l}\text { Raul Pereira } \\
\text { Arquitetos } \\
\text { Associados }\end{array}$ & $\begin{array}{c}\text { Raul Pereira } \\
\text { Arquitetos } \\
\text { Associados }\end{array}$ \\
\hline Manutenção & média & ruim & média & boa & média & média & boa & média \\
\hline Uso pela população & intenso & reduzido & intenso & médio & pouco & (não concluído) & intenso & (não concluído) \\
\hline $\begin{array}{l}\text { Qualidade de } \\
\text { Execução }\end{array}$ & média & boa & média & média & média & média & boa & média \\
\hline \multirow{2}{*}{ Grau de Execução } & \multirow{2}{*}{$\begin{array}{l}\text { incompleta }(20 \%) \\
\text { e suspensa }\end{array}$} & \multirow{2}{*}{ Concluída } & 1 a etapa $(100 \%)$ & $\begin{array}{c}\text { 19a etapa }(100 \%) \\
\text { setor leste }\end{array}$ & \multirow{2}{*}{ Concluída } & \multirow{2}{*}{ Parcial (20\%) } & $\begin{array}{c}1 \text { a etapa }(100 \%) \\
2003\end{array}$ & Parcial (5\%) \\
\hline & & & $\begin{array}{l}\text { 2a etapa } \\
\text { aprovada }\end{array}$ & $\begin{array}{c}\text { 2a etapa } \\
\text { aprovada }\end{array}$ & & & 2etapa (100\%) & $\begin{array}{l}\text { 2a etapa em } \\
\text { execução }\end{array}$ \\
\hline Área total $\left(\mathrm{m}^{2}\right)$ & 10.000 & 4.000 & 60.000 & 34.000 & 5.600 & 31.000 & 41.000 & 250.000 \\
\hline
\end{tabular}




\section{Praça Nandina Haddad Ambuda}

Situa-se no bairro do Morumbi (Subprefeitura Butantã), próximo à Avenida Giovanni Gronchi, eixo viário e comercial importante da região. O entorno possui uso residencial verticalizado, composto por torres construídas para público de alto poder aquisitivo. A região, inicialmente horizontalizada, encontra-se em acelerado processo de verticalização, concentrando alta quantidade de novos empreendimentos imobiliários.

O terreno da praça, com total de $5.600 \mathrm{~m}^{2}$, é definido pela prefeitura como Área Verde pública resultante de processo de parcelamento. Ele interliga duas vias locais de tráfego reduzido, possuindo formato alongado e relevo acidentado. A área é conformada por muros de fundo de lote de torres residenciais, sendo atravessada por tubulação hidráulica aparente, de considerável porte. As duas extremidades que conectam a praça às vias locais são conformadas por taludes íngremes, enquanto a parte central é praticamente um platô, com inclinação mais suave.

O processo que posteriormente viabilizaria a praça tem início no ano 2001, quando foi solicitada a aprovação de duas torres residenciais executadas por diferentes construtoras no bairro do Morumbi. A proposição de retirada de algumas árvores do terreno das obras resultou em compensações ambientais que previam o plantio de mudas compensatórias dentro do empreendimento. $\mathrm{O}$ excedente seria plantado em seu entorno.

O projeto de compensação ambiental foi direcionado ao Eng. Agr. e Arq. José Manoel Gobbi $^{166}$. Segundo ele, o DEPAVE estipulou apenas o valor a ser gasto na compensação e, devido ao porte da praça, redireciou a responsabilidade da escolha do local de plantio à Subprefeitura.

O processo para determinar o local que receberia o benefício demorou cerca de quatro meses. A densidade da arborização do entorno dificultava a identificação de um local para o plantio de novas mudas. Enquanto isso, o projeto ficou parado por falta de definição do local da compensação. Devido à morosidade do processo, a locação acabou sendo realizada por uma arquiteta da Subprefeitura, embora esta atribuição fosse geralmente de responsabilidade do engenheiro agrônomo da repartição.

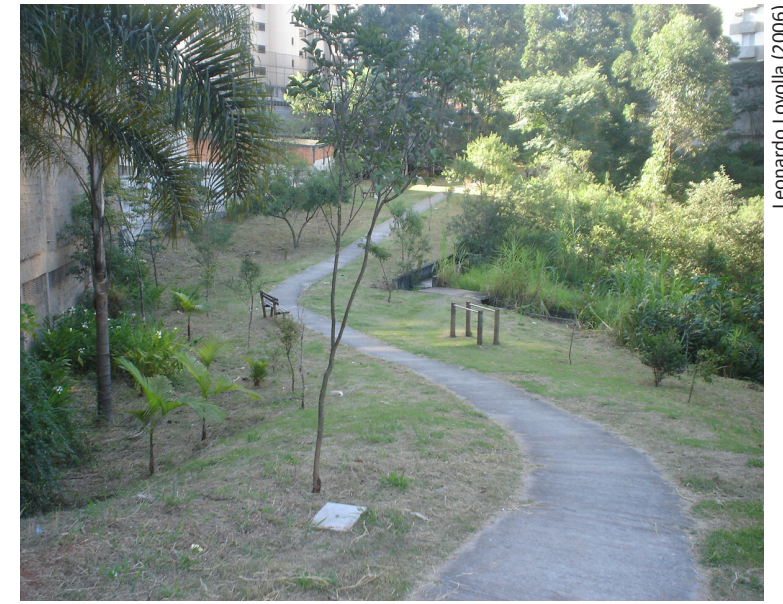

Vista do miolo da praça, conformada pelos altos e áridos muros dos edifícios de alto padrão do entorno.

166. Todos os depoimentos relacionados ao Eng. Agr. José Manoel Gobbi referem-se à entrevista realizada para este trabalho no dia 06.04.2006. 


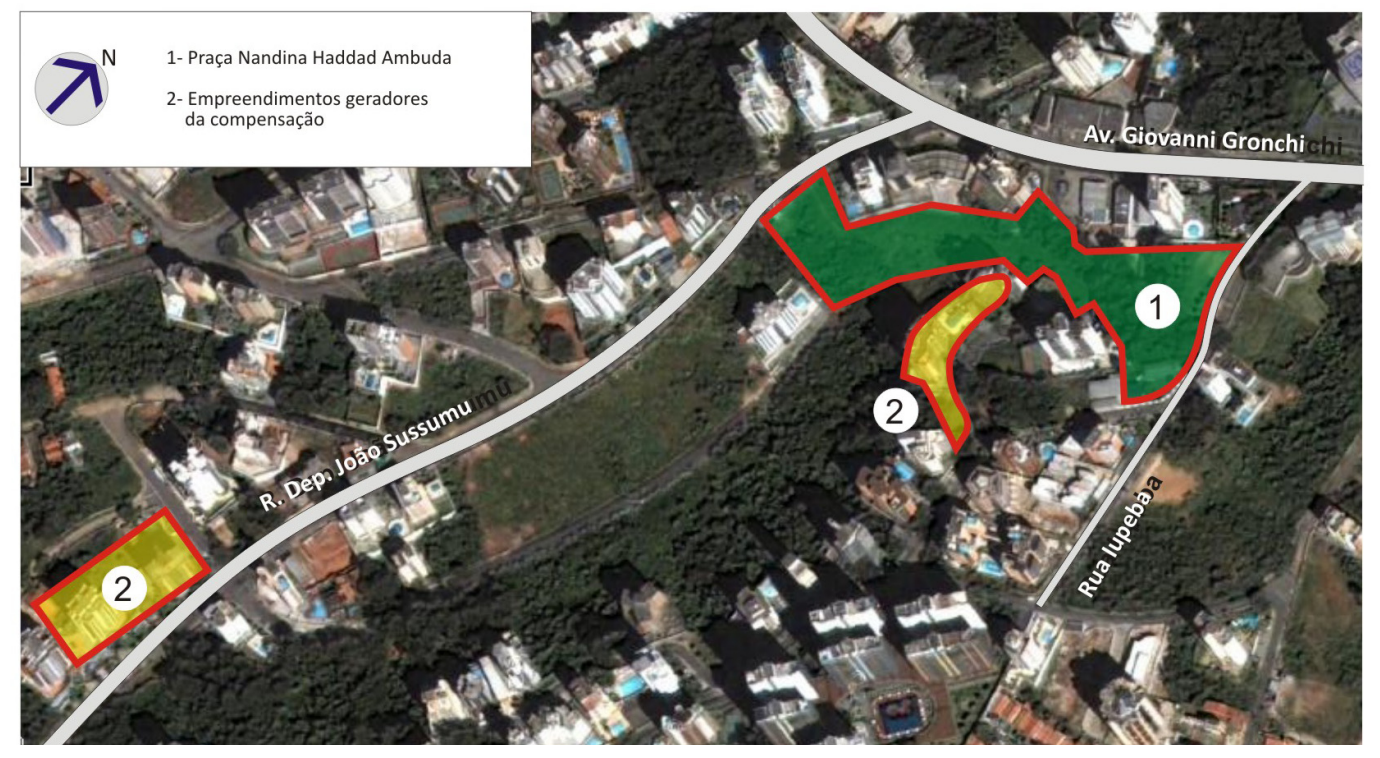

Planta de situação da praça em relação aos empreendimentos geradores do TCA

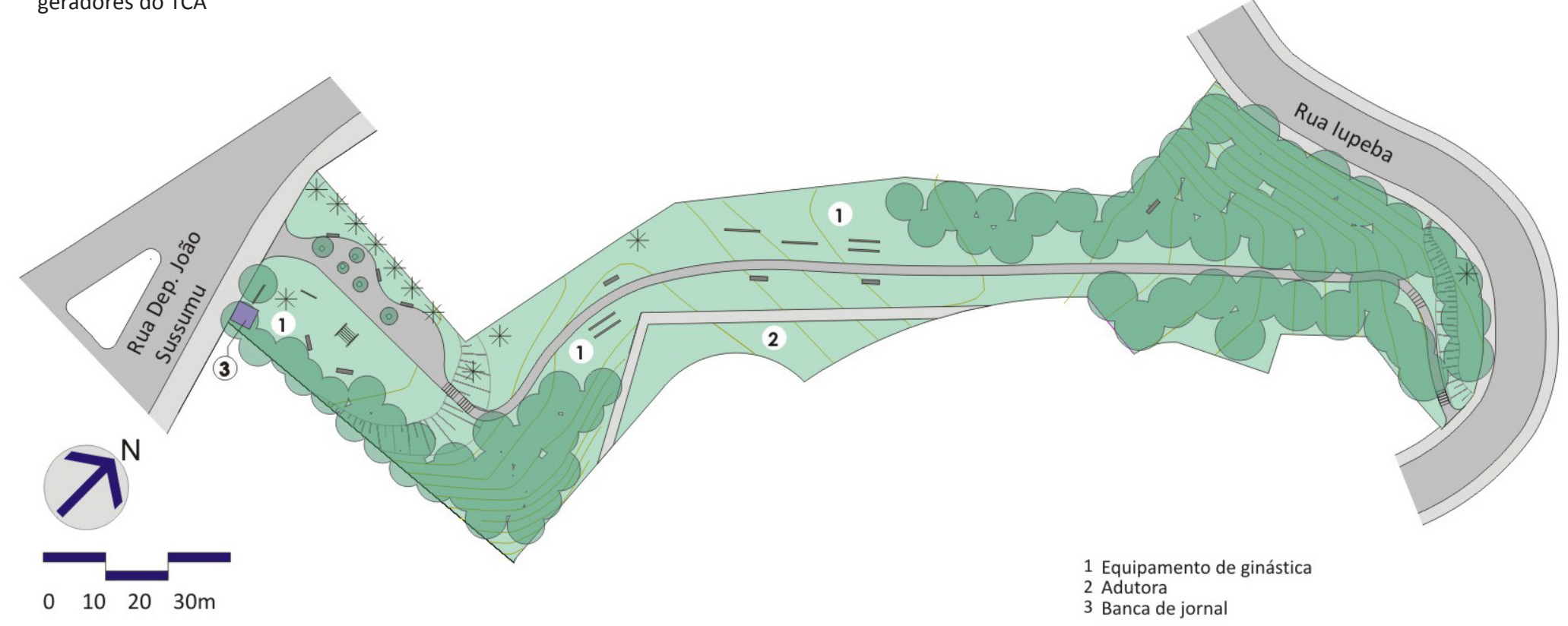


Devido às dificuldades com a locação de mudas, optou-se pelo custeio de obras e serviços para melhoramento de um espaço livre público. Tal alternativa compensatória foi criada naquela época (ano de 2001) e o processo seria o primeiro do gênero no município.

O projeto da praça envolveu a elaboração de um estudo para identificar o elemento polarizador de atividades no entorno, de modo a estabelecer vínculos com os moradores locais, e facilitar continuidade de sua manutenção. Adotou-se como uso focal uma atividade pouco usual: o adestramento de cães. Tal proposição, segundo o autor, foi feita em função da demanda por espaços do gênero na região, visto que os moradores locais pagavam adestradores para levar seus cães ao jardim do Palácio do Governo, localizado nas imediações. Gobbi cogitou, inclusive, a possibilidade de trazer adestradores da polícia como garantia de segurança para o local, visto que o medo de assaltos era uma das principais preocupações expressas pelos moradores quando estes foram consultados pelo projetista.

Também foi proposta a interligação das duas ruas que delimitavam a praça por meio de rampas e um caminho em piso processado, além da instalação de bancos e alguns equipamentos. Finalizado o estudo inicial, este foi apresentado ao DEPAVE, que solicitou o projeto executivo do espaço. Uma subdivisão do DEPAVE exigiu que o projeto fosse elaboradoconforme diversasnormas (contemplaçãodascondicionanteslocais, acessibilidade, etc.), mas estas ainda não tinham sido oficialmente emitidas, pois o uso daquele tipo de compensação era pioneiro. Tal problema gerou novos atrasos na concretização do projeto. Por fim, o caso foi levado ao diretor do departamento, que autorizou a construção. $\mathrm{O}$ projeto, no entanto, não teria mais espaço específico para adestramento de cães. Foram previstos apenas um caminho em cimentado, escadarias de acesso, bancos, brinquedos e equipamentos de ginástica.

Novos percalços ocorreriam com a viabilização. Quando foram iniciadas as obras, um promotor público residente em um prédio vizinho embargou a obra por alegar existência de curso d'água no terreno. Mais tarde foi comprovado pelo empreendedor (a próprio ônus) junto ao DEPRN, por meio de um mapa cartográfico, que se tratava apenas de um acúmulo de águas pluviais.

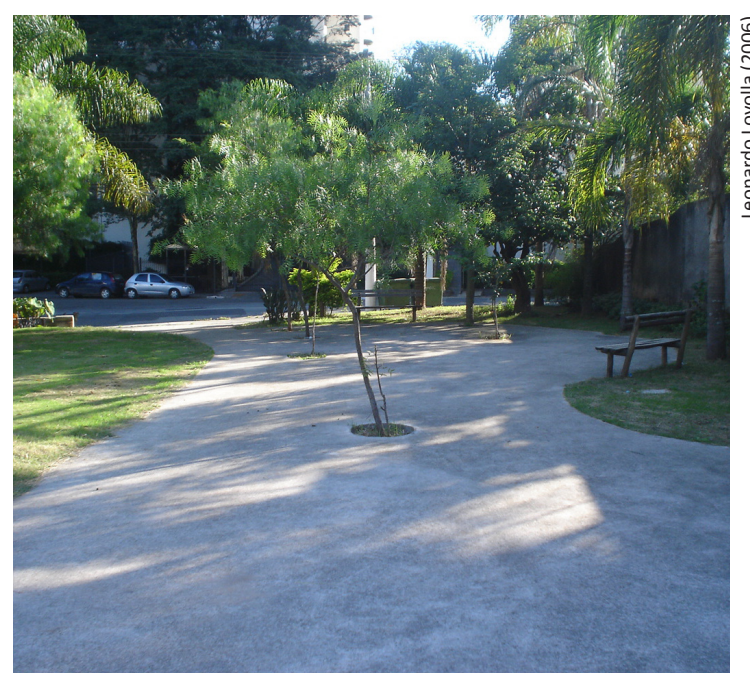

Acesso da praça pela Rua Dep. João Sussumu. Caminhos sinuosos em piso cimentado e áreas de estar. 
Em outro momento, a Comissão Permanente de Acessibilidade da prefeitura (CPA) questionou o acesso à praça. De fato, foram previstos locais do projeto onde a rampa seria mais íngreme que o permitido pela legislação. A CPA exigiu o uso de escadas ao invés de rampas, solução que faria com que o Portador de Necessidades Especiais só pudesse acessar alguns poucos trechos, nas extremidades da praça.

Próximo ao final da execução da praça, o DEPAVE passou a exigir instalações elétricas como escopo do projeto compensatório. Tal exigência elevou o preço da compensação acima do patamar previamente estabelecido por meio do documento. O pagamento de valores superiores ao solicitado na compensação não é permitido por lei. Desse modo, a empresa foi obrigada a fornecer o excedente sob forma de doação.

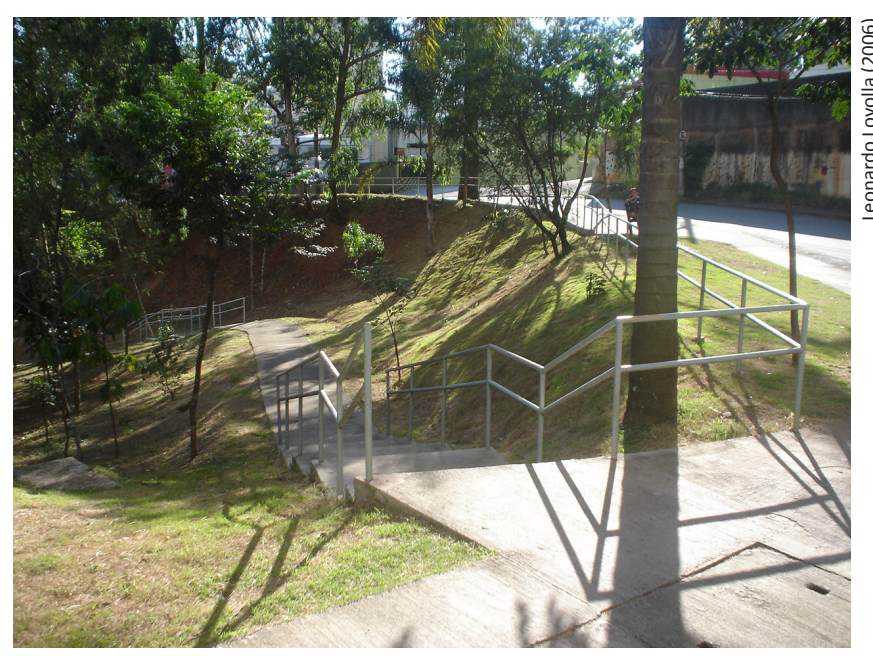

Acesso da praça pela Rua lupeba. Uso de escada, solicitado pela própria prefeitura, inviabiliza acess para portadores de necessidades especiais.
Acesso da praça pela Rua Dep. João Sussumu. Área de estar e playground.

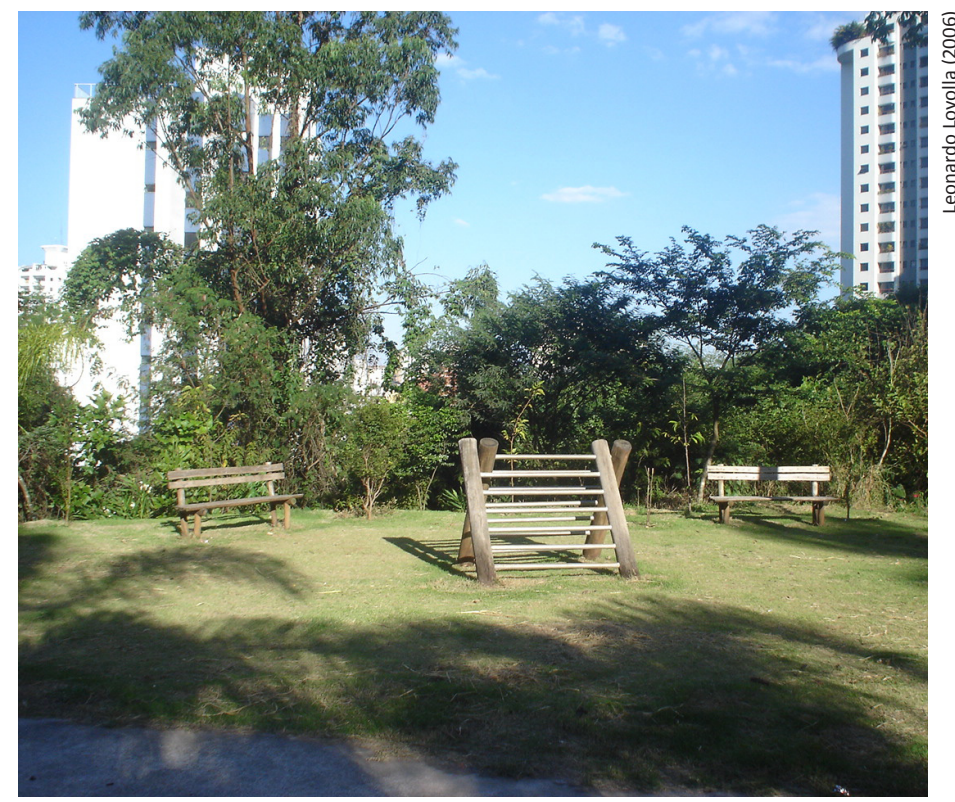

Finalizada a execução da praça, o DEPAVE recusou-se a assinar o termo de recebimento, alegando que a locação de árvores compensatórias dentro do terreno do empreendimento não tinha sido aprovada. Tal fato não procedia, mas como resultado do processo o DEPAVE multou o empreendedor por má execução. Após oito meses de sucessivas reclamações, o valor foi reduzido a um patamar bem menor que o inicial. Segundo Gobbi, o valor só não foi reduzido a zero para evitar o reconhecimento público do erro cometido pelo departamento.

Apesar do pagamento do valor estipulado, o termo de recebimento não foi concedido ao empreendedor. Para dificultar ainda mais a situação, o processo foi perdido nos arquivos do departamento durante a mudança da Gestão Marta Suplicy para a Gestão José Serra. O departamento exigiu que todos os papéis referentes ao processo fossem providenciados novamente. Posteriormente o processo foi encontrado. Em três vias iguais. 


\section{Parque do Cordeiro}

Localizado no bairro de Jardim Petrópolis (Subprefeitura de Santo Amaro - zona sul da cidade), o parque situa-se em área contígua à Av. Prof. Vicente Rao. Esta via compõe um sistema que interliga o município de Diadema à Marginal do Rio Pinheiros, na altura do bairro do Morumbi.

O entorno do parque possui uso predominantemente residencial horizontalizado (zoneamento Z1 e Z2), sendo ocupado por uma população de renda média-alta. A exemplo do bairro vizinho de Alto da Boa Vista, a região concentra famílias de origem germânica. O processo de urbanização do entorno iniciou-se no fim da década de 1950, e possibilitou a criação de vias bastante arborizadas na região. A partir da década de 1990, as características do bairro começaram a ser alteradas pela implantação de condomínios horizontalizados - vilas residenciais - que vêm gradualmente modificando o perfil dos moradores da região e a forma como estes se relacionam. As vilas residenciais conferiram um caráter mais isolado das unidades residenciais em relação ao entorno, por meio de extensos e altos muros.

O terreno do parque é uma área livre pública resultante do processo de parcelamento do bairro no ano de 1957. A área é seccionada aproximadamente em sua metade pela Rua Breves, via que desempenha papel significativo para interligação da região. No projeto paisagístico inicial do parque as duas porções resultantes da divisão pela rua foram designadas respectivamente como Setor Leste e Setor Oeste.

O setor leste, situado ao lado da Av. Prof. Vicente Rao, é delimitado por vias de circulação de veículos e possui área de aproximadamente $14.000 \mathrm{~m} 2$. Esse setor desempenhou papel focal no projeto do parque, devido ao maior movimento de pedestres e veículos no seu entorno. Por esse motivo, foi escolhida como primeira fase para implantação do projeto paisagístico.

O local não possuía massa significativa de vegetação arbórea e sua topografia, que inicialmente apresentava desnível distribuído ao longo do terreno, foi ajustada por sucessivos aterros de modo a criar um grande talude separando-a da Av. Prof. Vicente Rao. 
Av. Prof. Rubens Gomes de Souza

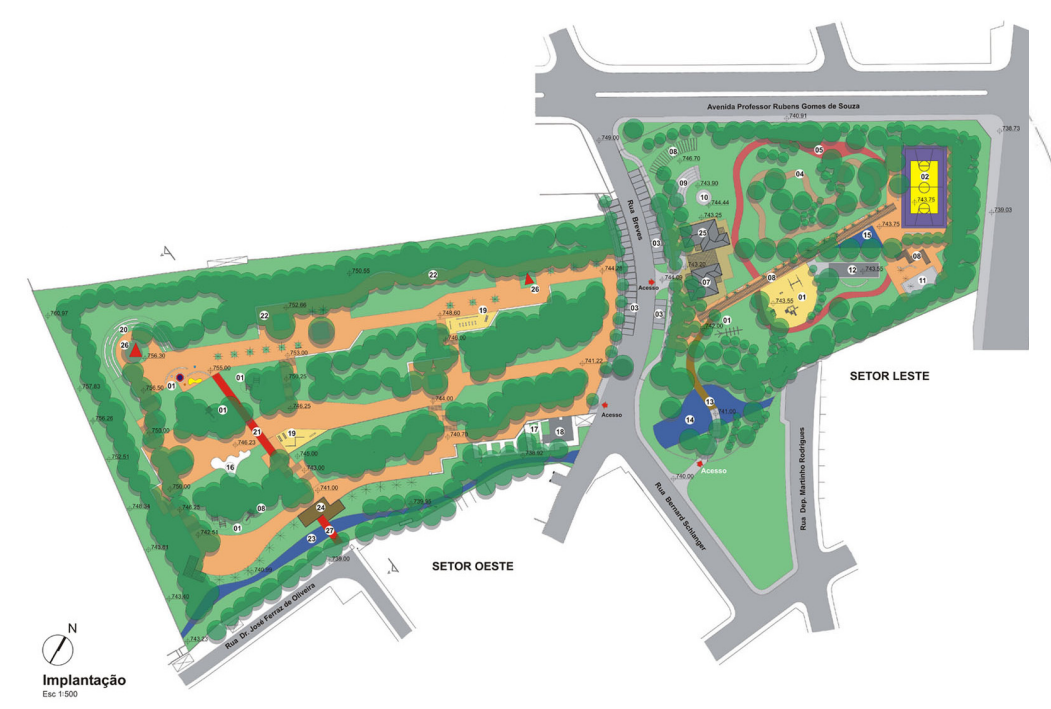

Planta dos setores leste e oeste.
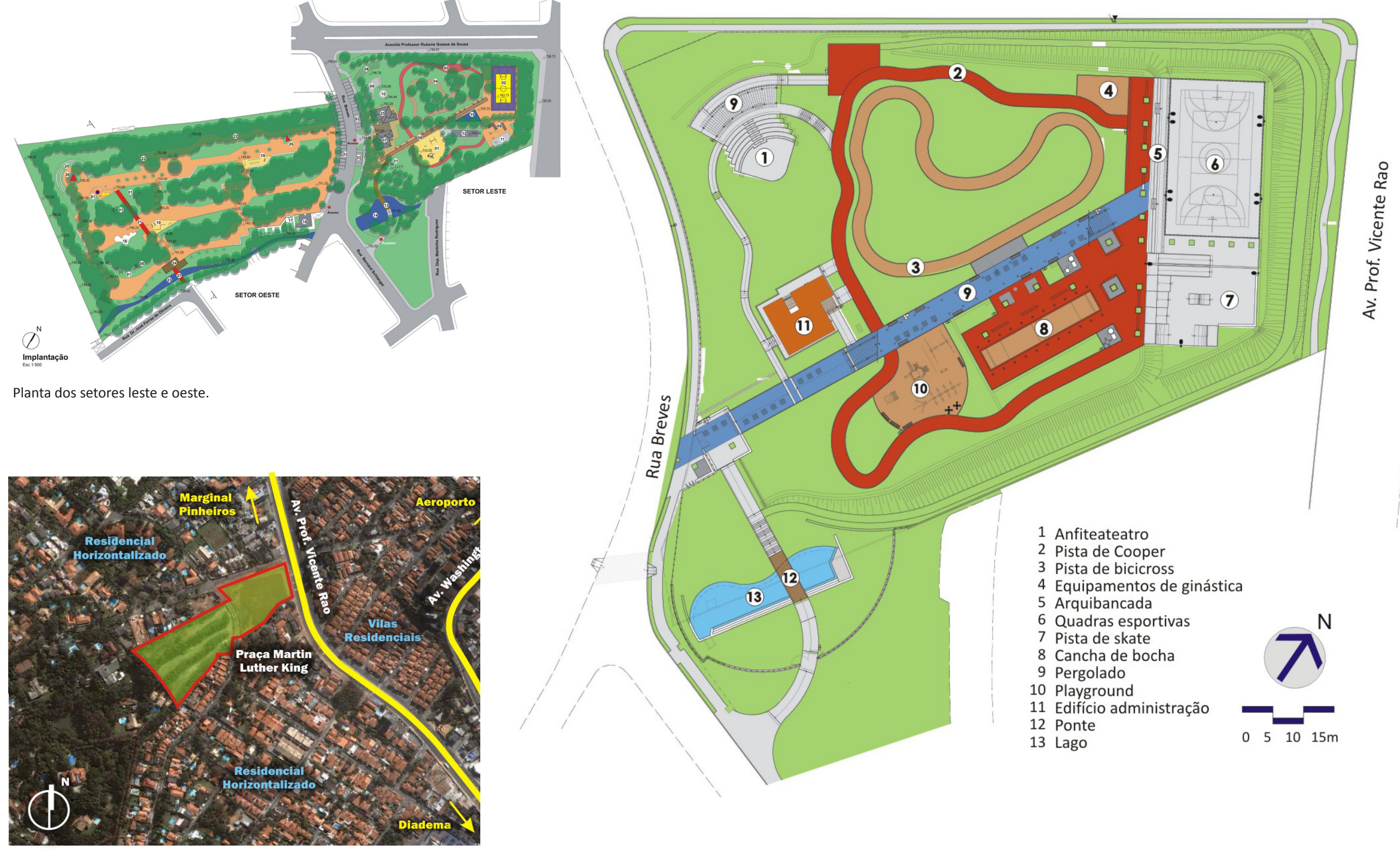


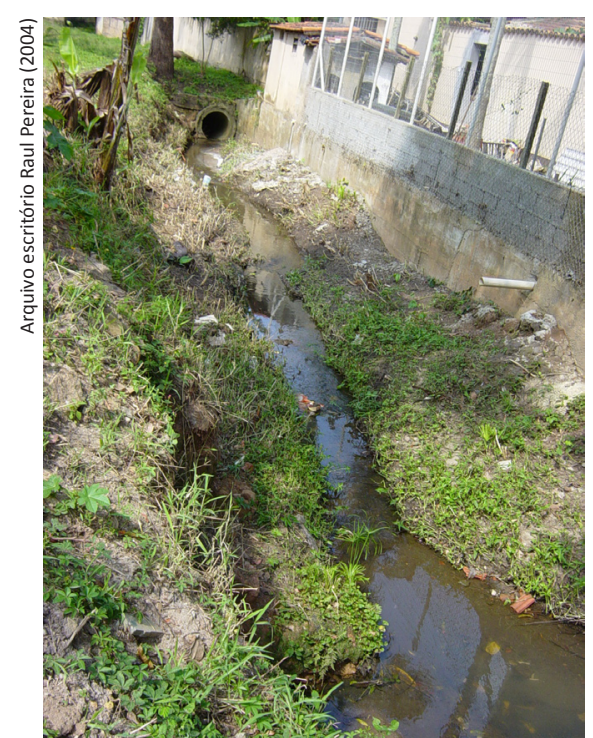

Córrego do Cordeiro

167. . Na zona sul, área de lazer não saiu do papel. Folha de São Paulo. Caderno Cotidiano. 25 janeiro 2004 168. A SAJAPE é uma organização não-governamental (ONG) fundada em 1999, que no ano de 2007 contava com 400 sócios e uma diretoria composta por 12 membros, atuando vida dos bairrostes que visam à preservação da qualidade de vida dos bairros que abrange. Para tanto, promove eventos,
O setor oeste possui relevo mais acidentado em comparação à porção leste, sendo coberto por massa arbórea significativa, composta predominantemente por eucaliptos. Sua área é de cerca de $20.000 \mathrm{~m} 2$, portanto, superior à da porção leste. Apenas duas das quatro divisas desse trecho são feitas por ruas, o que confere ao local menor fluxo de veículos e pedestres. Em sua cota mais baixa, a área abriga um trecho a céu aberto do córrego que dá nome ao parque.

Até ser cogitada sua transformação em parque, o local permaneceu sem uso definido, o que ocasionou diversos problemas fundiários.

Em 2000, uma ação civil pública foi movida contra a Prefeitura do Município de São Paulo foi patrocinada por diversas associações de moradores do entorno, que já vislumbravam a possibilidade de transformar o local em um parque público. $\mathrm{O}$ ato visava revogar a doação daquele terreno à entidade civil "Conselho Superior para Assuntos Islâmicos no Brasil", realizada em contexto obscuro no ano de 1995, pela Lei Municipal no 11.799.

Embora essa ação tenha sido bem sucedida, um ano depois a área enfrentaria novo problema com relação à sua posse. O problema dessa vez foi ocasionado pelo próprio vigia do terreno:

Em 2001, um 'morador' do terreno público, também funcionário da prefeitura e então vigia da área, acabou vendendo-o ilegalmente por R \$200 mil (estava avaliado em R \$15 milhões). Só dois anos, uma invasão de sem-teto e muita briga depois, a Justiça devolveu a área ao domínio público. ${ }^{167}$

Portanto, só no ano de 2003 o terreno seria declarado "Área Verde pública” por meio de Decreto Municipal. Tal ato, embora reforçasse a destinação para fins recreativos, não era suficiente para sua implantação. A partir de então, inicia-se a luta dos moradores locais para a transformação efetiva do terreno em parque público.

Nesse sentido, foi decisiva a atuação da Sociedade Amigos do Jardim Petrópolis e dos Estados (SAJAPE) ${ }^{168}$. A exemplo de Organizações não Governamentais como a Sociedade Amigos do Brooklin Velho (SABROVE), a entidade é coordenada por uma equipe interdisciplinar com conhecimento da legislação existente e disposição para fazer valer seus direitos. 
Especificamente no caso do Parque do Cordeiro, exercem papel de destaque a Arq. Maria Cristina Antunes e a Geogr. e Educadora Ambiental Ana Beatriz Goshuen. Ambas trabalharam no esclarecimento da comunidade quanto à importância do parque e na divulgação do mesmo. Essa divulgação é realizada tanto pelo periódico da associação quanto no "boca-a-boca". Paralelamente, foi feito um estudo detalhado da legislação paulistana de compensações ambientais como forma de exercer pressão e adquirir maior poder de barganha perante os órgãos públicos. Sem a persistência desse trabalho junto à prefeitura, possivelmente o parque não teria saído do papel, sobretudo devido aos percalços proporcionados pela fragmentação de recursos financeiros para execução.

Em 2001, época que o parque começou a ser viabilizado, o uso de compensações ambientais para custear obras e serviços era pioneiro. Até então, árvores eram trocadas exclusivamente por árvores. Em seu início, os montantes para custeio de obras civis eram pequenos e provenientes de diferentes locais. Essa condição, por sinal, ainda é observada no ano de 2008.

Ao mesmo tempo, a área era objeto de pendências jurídicas, devido ao já citado problema de "grilagem" realizada por um vigia do terreno. Tal fato impossibilitou por algum tempo que a área recebesse recursos de compensações e adiou o início da construção do parque. A viabilização do parque só ocorreria depois de resolvidos os problemas jurídicos.

O projeto teve início no ano de 2003, com recursos provenientes de um TCA de empreendimento residencial do entorno do parque. Essa compensação ambiental custeou o levantamento topográfico do terreno e posteriormente financiaria também o estudo preliminar do setor leste, realizado pelo escritório de arquitetura Salata e Orsini.

No estudo preliminar, o projeto trabalhou predominantemente atividades de lazer ativo, condizentes com o caráter polarizador proposto desde o início para essa área. O programa previa uma sede administrativa para o parque, pergolado, anfiteatro, pista de Cooper, pista de bicicross, quadras esportivas, pista de skate e brinquedos. Também foi concebido um lago na cota inferior do terreno, que faz divisa com a Praça Martin Luther King. Tal lago seria objeto de futuras polêmicas.

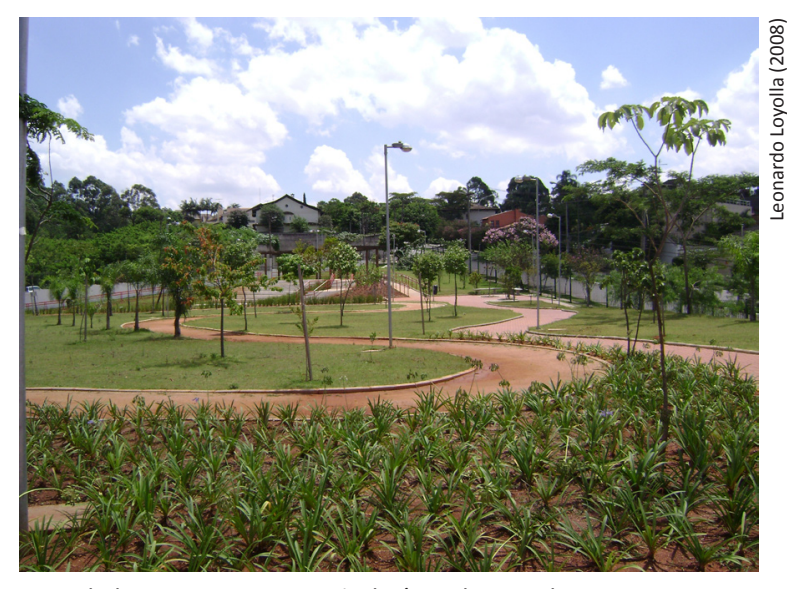

Pista de bicicross vista a partir da área das quadras

Edifício da administração do parque visto a partir da pista de Cooper

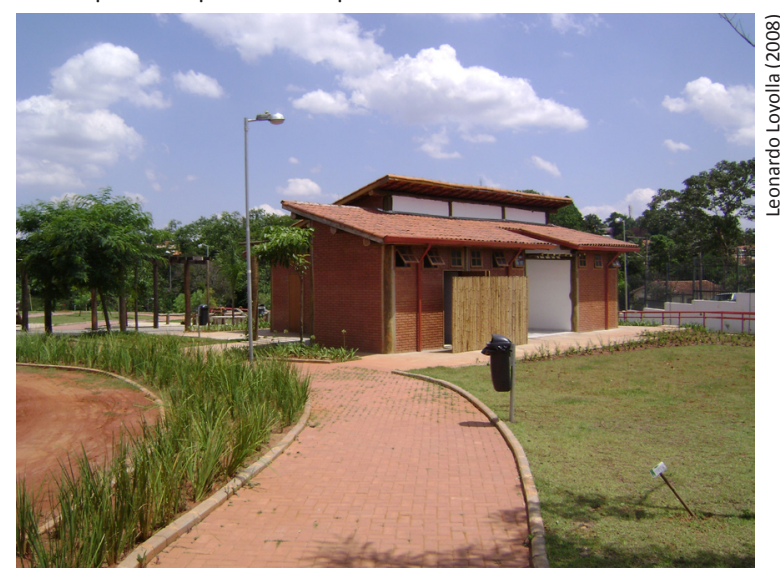




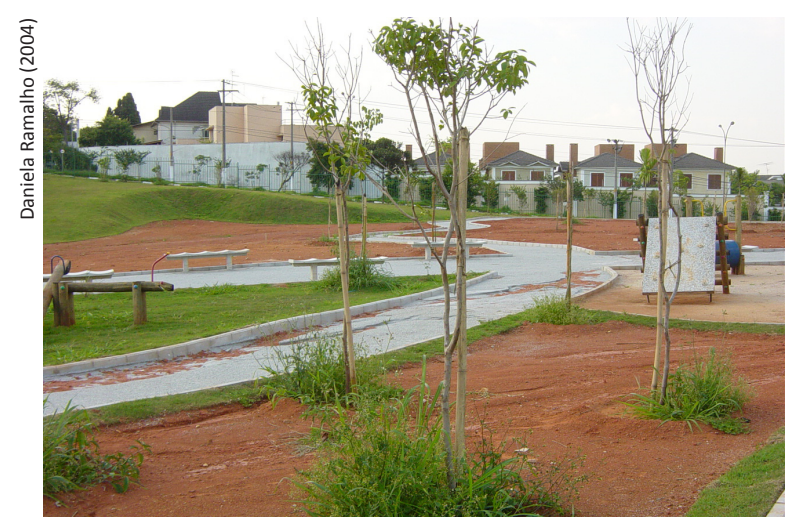

Problemas na execução inicial das obras do setor leste: drenagem insuficiente da pista de caminhada e plantio inadequada de mudas

Reunião para apresentação do projeto pelo arquiteto Raul Pereira (primeiro da esq. p/ direita).

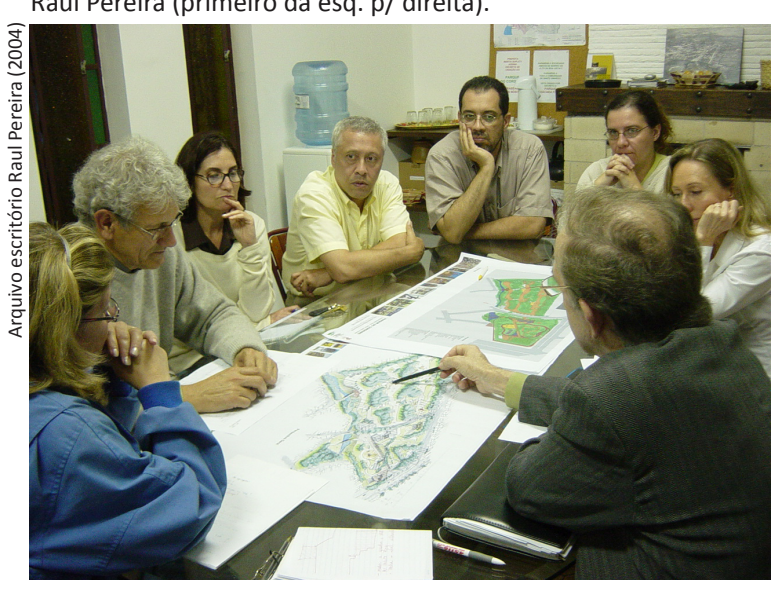

169. Informações fornecidas na entrevista realizada em 21.01. 2007
Nessa etapa da concepção, como é relatado por geog. Ana Beatriz Goshuen ${ }^{169}$, uma das principais atuações da SAJAPE era no sentido de evitar que os recursos de TCAs do entorno do parque fossem direcionados para outras áreas do município. Segundo ela, mesmo com a pressão exercida, uma parte das compensações foi direcionada para parques de outras regiões da cidade, como o Pinheirinho D'água e Guarapiranga.

Os recursos iniciais previstos para o parque foram suficientes para realizar movimentações de terra, o seu cercamento, a colocação de bancos de concreto, brinquedos e o plantio inicial. Algumas dessas ações resultaram em problemas posteriores, como se verá a seguir.

O terrapleno do Setor Leste alocou grandes quantidades de terra, criando um talude que separou o parque em relação à Av. Prof. Vicente Rao e condicionou negativamente as etapas subseqüentes do projeto.

O plantio foi realizado antes mesmo das obras construtivas, o que comprometeu a sobrevivência das mudas. A imprecisão na colocação das árvores também dificultou as futuras locações de equipamentos. Tal modo equivocado de conduzir os investimentos no parque ocorreria de modo semelhante a outras áreas custeadas por TCA, como o Parque Pinheirinho D'Água. O processo ocorria do seguinte modo: tão logo era comunicada a existência de uma nova compensação, iniciava-se uma verdadeira "corrida" para que os recursos obtidos não fossem direcionados para outros fins. Isso resultou em ações precipitadas, que comprometeram o andamento do projeto. Esse tipo de ação evidencia um problema ainda existente no ano de 2008: a falta de planejamento dos locais onde as compensações serão aplicadas.

Ainda no ano de 2003, o projeto foi direcionado ao escritório do arq. Raul Pereira, que seria responsável pelo detalhamento da proposta inicial. $\mathrm{O}$ aprofundamento do projeto do setor leste seguiu o traçado e o programa proposto pelo escritório Salata e Orsini, mas ao mesmo tempo teve de adaptar-se às obras já realizadas no terreno e às imprecisões do levantamento topográfico inicial. 
Paralelamente, foi realizado o estudo preliminar do setor oeste. Esse projeto teve como diretriz básica a proposição de atividades de lazer contemplativo, como áreas de estar e caminhos ao longo dos bosques já existentes no terreno. Além disso, o Córrego do Cordeiro foi mantido a céu aberto, permanecendo como um dos elementos estruturadores do parque.

Essa fase da concepção foi custeada por TCAs provenientes das obras para corredores de ônibus no eixo formado pela Avenida Ibirapuera e Vereador José Diniz. Os mesmos recursos foram suficientes para executar obras de drenagem e a implantação de brinquedos no setor leste.

Embora essas obras já tivessem sido executadas e o parque pudesse ser utilizado, a área permaneceu fechada ao público. A SAJAPE realizou inúmeras tentativas de abertura do parque ao público, inclusive como forma de assegurar que a área não fosse invadida. Segundo resposta dada pelo DEPAVE à SAJAPE naquela época, a demora para abertura do parque foi gerada porque o mesmo ainda não estava completamente executado. Por si só, esta razão não seria suficiente para impedir sua abertura, pois já haviam sido implantados diversos equipamentos que permitiam seu uso pela população. Além disso, os parques Jacintho Alberto e Vila Prudente foram abertos ao público ainda incompletos. Mais que a incompletude das obras, o que de fato adiou a abertura do parque foram os problemas com sua execução (tais como falhas no sistema de drenagem e locação incorreta de mudas) e lentidão no processo de aprovação.

O detalhamento final do projeto seria realizado a partir do ano de 2005, custeado por recursos provenientes de TCAs de uma empresa de grande porte do setor imobiliário paulistano. Nesse momento, o escritório de Raul Pereira atuou em parceria com o escritório Núcleo da Paisagem. Essa equipe também detinha experiência em obras do gênero, pois já havia realizado o projeto do Parque Colinas de São Francisco, localizado na zona oeste paulistana.
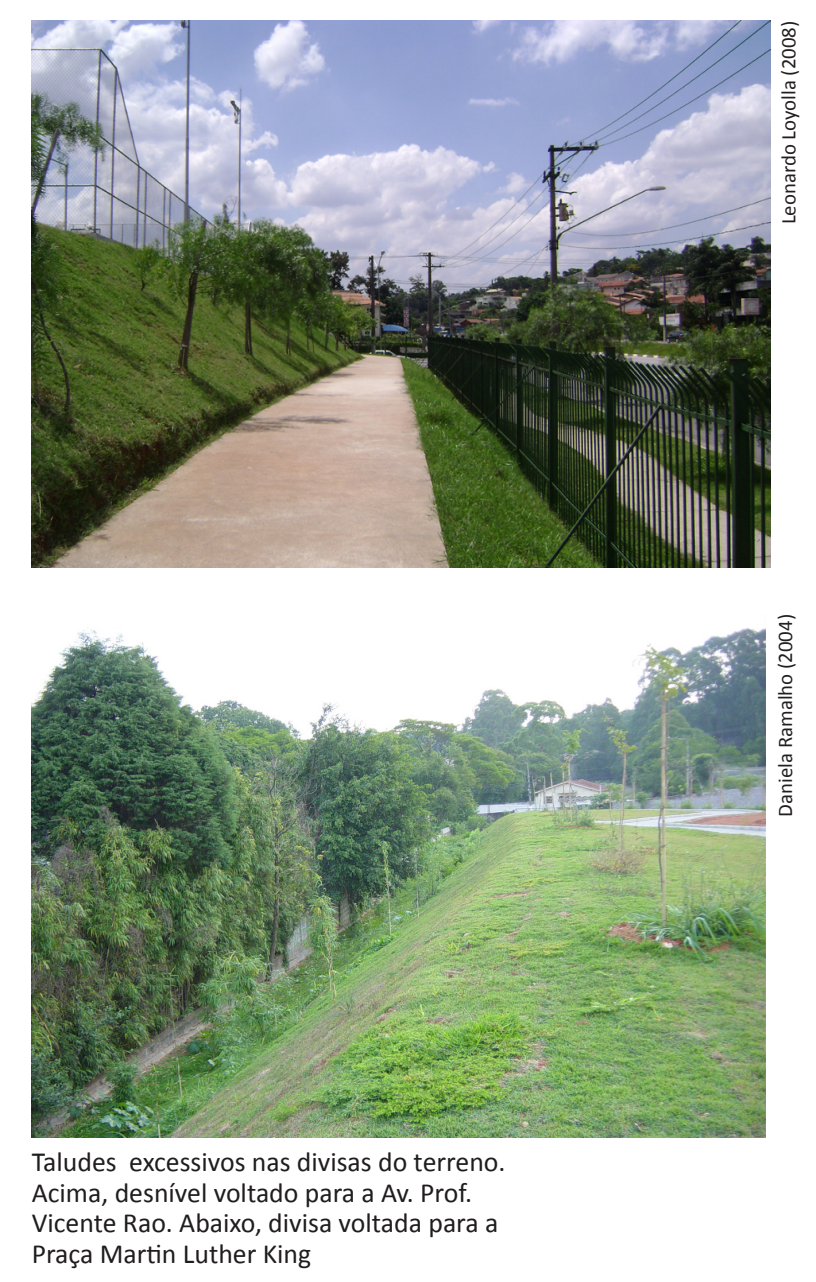


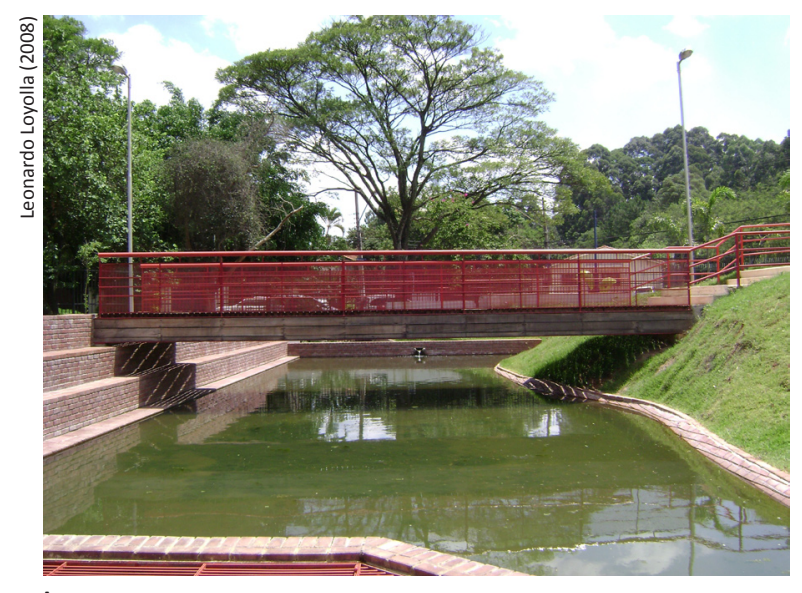

Lago

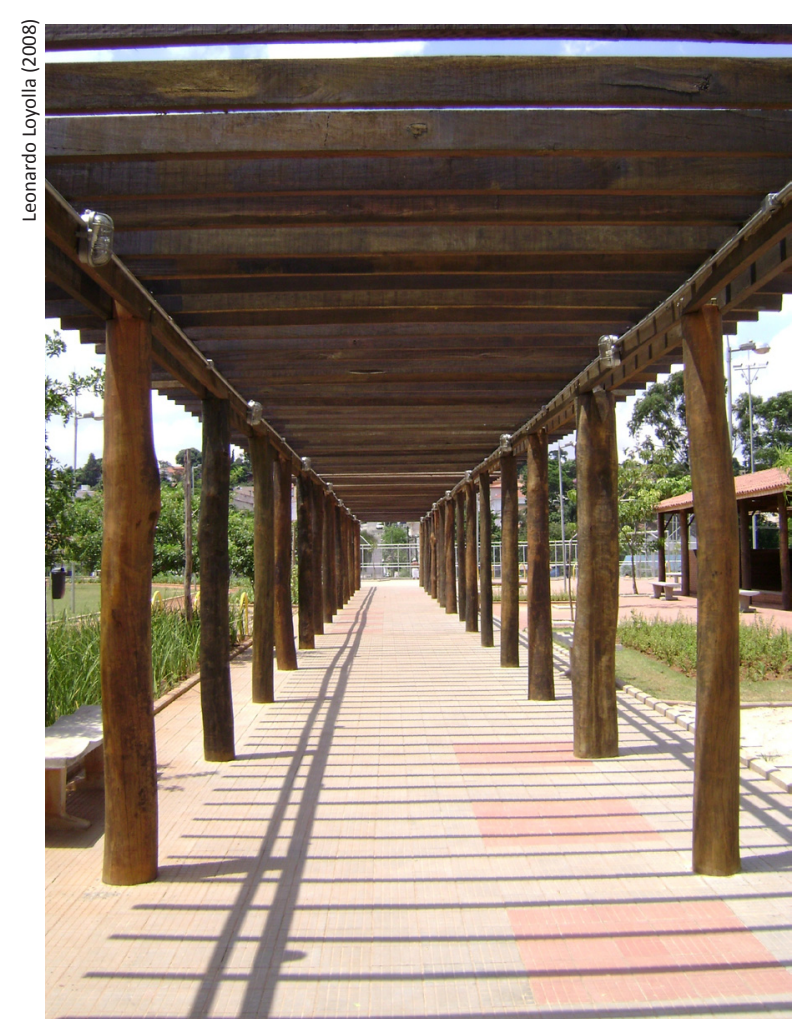

Pergolado do acesso principal do setor leste
A partir de 2006, as compensações ambientais deixam de custear as obras do Parque do Cordeiro. No final desse ano inicia-se a execução completa do Setor Leste, cujos montantes para execução viriam de recursos diretos do município, intermediados pela Subprefeitura de Santo Amaro.

Durante as obras para finalização, o parque enfrentaria novamente problemas com a execução. Desta vez, a questão envolvia o lago previsto desde o estudo preliminar do parque. A necessidade do lago foi questionada pela comunidade, que alegava problemas com a futura manutenção e uso inadequado de suas águas - por sinal, problemas efetivos na cidade de São Paulo. Opondo-se a esse ponto de vista, estava a Arq. Maria Cristina Antunes, que entendia o equipamento como importante, por auxiliar na retenção de águas pluviais e como qualificador do projeto. A polêmica desenrolou-se por cerca de dois meses, até que fosse optado pela sua execução. O setor leste completamente finalizado foi inaugurado oficialmente em setembro de 2007.

O aspecto mais marcante a respeito do processo de viabilização do Parque do Cordeiro é a interação constante da comunidade em todas as suas etapas. Sem essa participação, possivelmente a área não teria saído da fase de projeto, sobretudo devido aos diversos obstáculos causados pela fragmentação dos recursos para sua execução. 

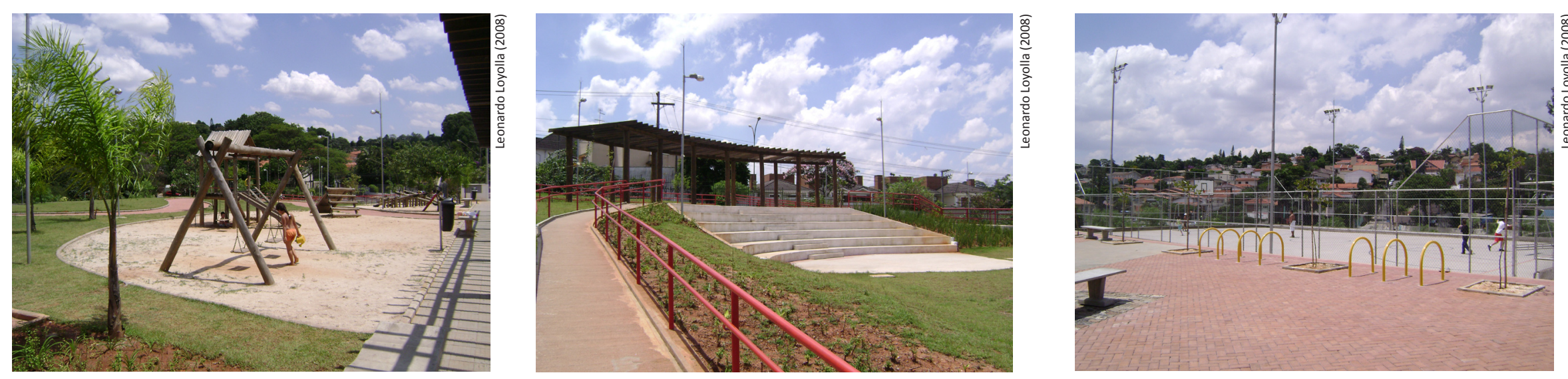

Da esquerda para a direita: playground, anfiteatro e área das quadras 


\section{Parque Pinheirinho D’Água}

Parque situado no bairro de City Jaraguá, na região noroeste da cidade (Subprefeitura de Pirituba/Jaraguá). As principais vias do entorno são a Av. Raimundo Pereira de Magalhães antiga Estrada de Campinas - e a Estrada de Taipas, via derivada desta anterior que entrecorta alguns trechos do parque.

Seu entorno é formado principalmente por conjuntos habitacionais de baixa renda com grande densidade populacional, construídos em meados da década de 1980 tanto pela prefeitura quanto pelo Governo do Estado. Essas construções são uma resposta tardia às pressões de movimentos populares que reivindicavam espaço para moradia em meio aos sucessivos aumentos populacionais dessa área, que ainda ocorrem no ano de $2008^{170}$. Também resultam desse processo as diversas ocupações irregulares encontradas no entorno. Destacam-se ainda, alguns empreendimentos industriais, atraídos pela proximidade ao sistema rodoviário Anhanguera-Bandeirantes e ao Rodoanel.

A região abriga a maior quantidade de parques públicos do município. São eles: os parques estaduais da Cantareira e Jaraguá, e os parques municipais Rodrigo de Gásperi, Anhanguera, São Domingos, Jardim Felicidade, Jacintho Alberto e Cidade de Toronto. Todos estes ocupam terrenos acidentados e possuem água como um de seus atrativos, característica também comum ao Parque Pinheirinho d'Água.

Localizado próximo à Serra da Cantareira, o parque possui topografia bastante acidentada, além de apresentar significativas áreas de mata ciliar e cobertura arbórea. Também abriga uma nascente e três córregos - Poço Grande, Vargem Grande e Pinheirinho d’Água. Este último, que deu nome ao parque, refere-se à vegetação aquática de pequeno porte existente no local.

O terreno do parque é o resultado da união de duas áreas públicas. Uma delas, com um total de $250 \mathrm{mil} \mathrm{m} \mathrm{m}^{2}$, pertencia à prefeitura do município, tendo sido gerada pelo parcelamento do empreendimento industrial City Jaraguá. A outra área, com $30 \mathrm{mil} \mathrm{m}^{2}$, pertencia ao Governo do Estado, tendo como destinação original a implantação de 300 unidades habitacionais da CDHU - Companhia de Desenvolvimento Habitacional e Urbano.

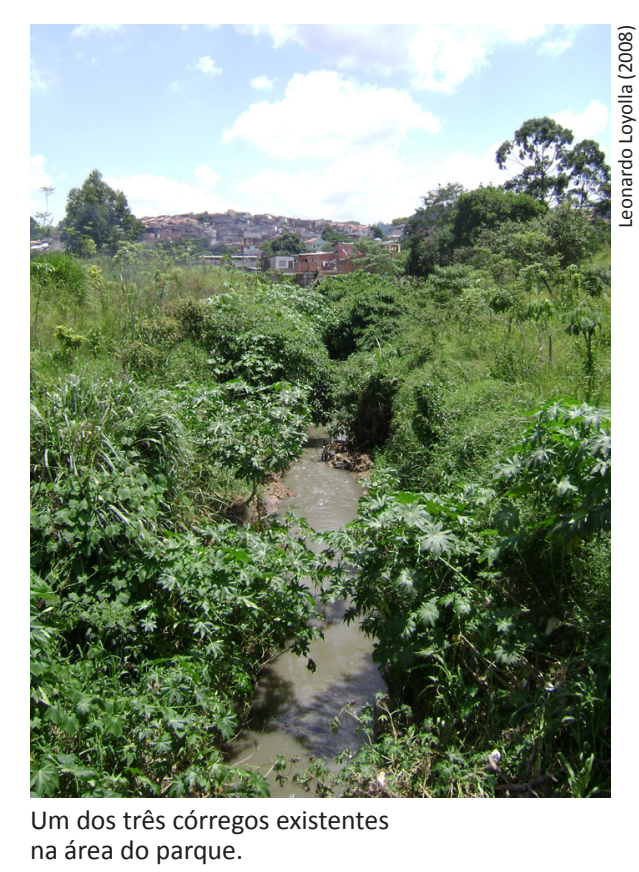

170. Segundo o Atlas Ambiental do Município, o distrito de Jaraguá, onde se localiza o Parque Pinheirinho D'Água, teve uma taxa de crescimento de 1,56\% entre os anos de 1991 a 2000. Nesse mesmo período, a taxa de crescimento médio da cidade foi de $0,91 \%$. 

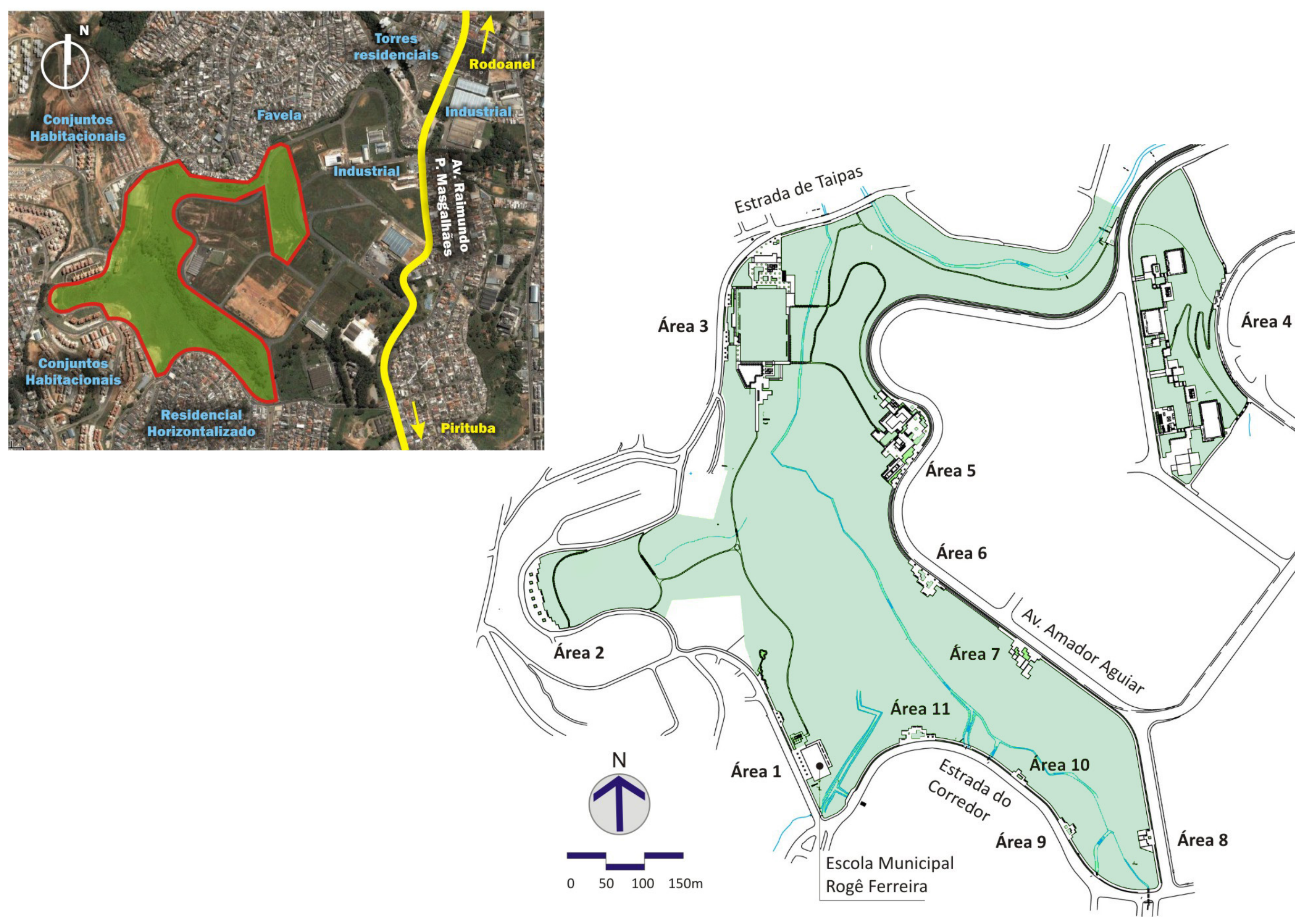
171. BOUCINHAS, Caio. Projeto participativo na produção do espaço público. Tese de Doutorado. São Paulo: FAUUSP, 2005 172. Informação fornecida pelo Arq. Caio Boucinhas em entrevista realizada em 10.01.2007
Devido a um processo movido pela Secretaria Estadual do Meio Ambiente, as obras foram embargadas em função da existência de uma nascente no terreno.

A história do parque tem relação intrínseca com os movimentos por moradia existentes na região desde 1985. Nesse ano, após sucessivas invasões tratadas com descaso pelas diferentes escalas de atuação do Poder Público, foram iniciadas as obras dos conjuntos habitacionais pela CDHU e através de mutirões promovidos pela prefeitura ${ }^{171}$.

Por não ser murada, a área resistiu com bastante dificuldade às invasões para fins de moradia. Essa resistência deve-se em boa parte ao nível de conscientização acima da média de moradores do entorno como Donizete Fernandes, coordenador da entidade União Movimento de Moradia (UMM). Ele relata que, quando os moradores locais tomaram conhecimento do fato da área verde correspondente ao CDHU não ter sido edificada em razão da nascente que abrigava, cresceu a identidade e a busca pela preservação e destinação da área como espaço livre recreativo ${ }^{172}$. A consciência a respeito do potencial da área como elemento de qualificação do local onde moravam também contribuiu para a proteção da área pela própria comunidade.

Embora o uso como espaço livre recreativo estivesse nas aspirações da comunidade desde o processo da SMA sobre a área da CDHU, o movimento efetivo para transformar areão local em parque começou em 2001, por meio de mobilizações da comunidade local e pressão aos órgãos públicos.

Nesse ano foram realizadas reuniões entre moradores, políticos locais e técnicos da prefeitura para reivindicação do parque. Essas reuniões, realizadas na Secretaria Municipal do Verde e Meio Ambiente, foram viabilizadas devido a pedidos de um vereador e um deputado estadual.

Inicialmente a proposta foi encarada com ceticismo pelos técnicos do Poder Público, sob o argumento de empecilhos diversos, tais como falta de recursos, falta de levantamentos e projeto específico para a área, além da necessidade de repasse do terreno pertencente à 
CDHU para o município. Devido à proposta de um dos moradores, foi agendada reunião com a CDHU.

Paralelamente, outra iniciativa auxiliaria na busca da consolidação da área como parque. Em conversa com moradores locais, o Arq. Caio Boucinhas, diretor do DEPAVE de 2001 a 2003, propôs um concurso para escolha de um nome para a área. Segundo Boucinhas:

[...] como na época a área era conhecida como Parque Panamericano, os moradores sugeriram que o nome fosse modificado para não ser caracterizado de um só grupo, o do bairro Parque Panamericano $[\ldots]^{173}$

A reunião com a CDHU resultou no apoio dessa entidade ao processo de transferência do terreno para o município. Ao mesmo tempo, o processo de batizado do parque reforçou a união dos moradores pela causa. A escolha foi realizada entre seis alternativas, em festividade onde estiveram presentes moradores, técnicos da prefeitura, subprefeitos e políticos locais. Foram também realizadas nessa época por professores e alunos locais diversas visitas a parques da região e ao próprio terreno. Essas visitas objetivavam a realização do diagnóstico das necessidades e expectativas com relação ao novo parque.

No ano de 2002 o processo de viabilização foi ampliado com a inserção do projeto do parque em uma disciplina de pós-graduação da Área de Paisagem e Ambiente da Faculdade de Arquitetura e Urbanismo da Universidade de São Paulo. O trabalho, entitulado "Propostas de potencialização e apropriação do ambiente do Parque Pinheirinho D’Água em Pirituba”, foi proposto para uma turma com cerca de 30 alunos da disciplina "Estúdio da Paisagem", ministrada pelos professores Catharina Cordeiro Lima e Paulo Pellegrino.

Foram montadas quatro equipes, que trabalhariam utilizando a metodologia projetual conhecida como charrette. Boucinhas explica o processo do seguinte modo:

No final do século XIX, em Paris, algumas questões urbanas, após levantamentos e discussões, eram levadas para a Escola de Arquitetura da Escola de Belas Artes onde, por um curto período, cinco ou seis dias, conhecendo todos os dados e informações disponíveis, equipes interdisciplinares
173. BOUCINHAS, Caio. Projeto participativo na produção do espaço público. Tese de Doutorado. São Paulo: FAUUSP, 2005. Cap. IV 


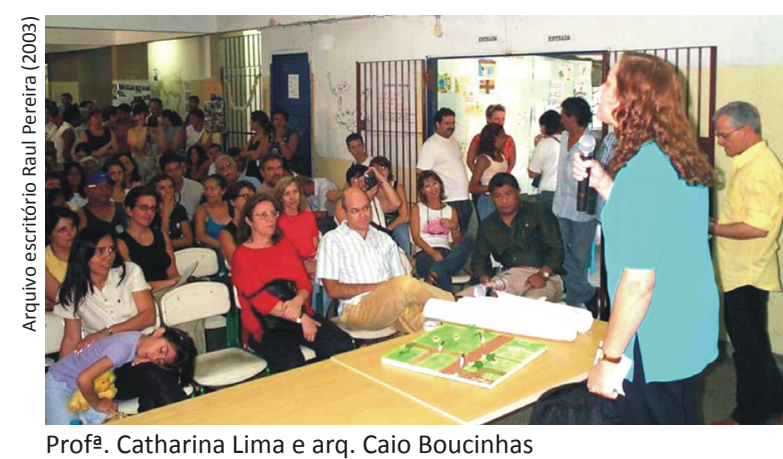

Profa. Catharina Lima e arq. Caio Boucinhas

apresentam as propostas à comunidade na Escola Municipal Rogê Ferreira. Sentado na primeira fileira o prof. Paulo Pellegrino.

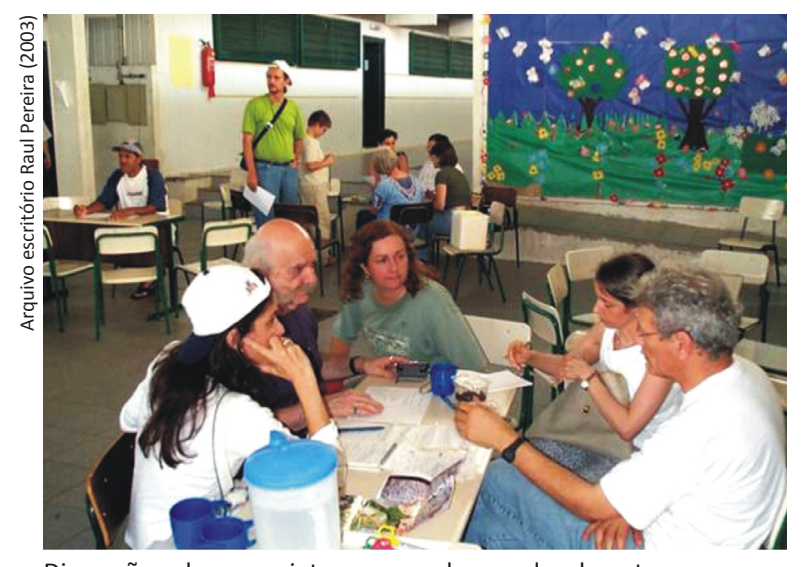

Discussão sobre o projeto em uma das escolas do entorno do parque. Entre os participantes, o arq. Raul Pereira (camiseta branca), a profa. Catharina Lima (camiseta verde) e o arq. Henry Sanoff (ao lado de Catharina)

174. BOUCINHAS, Caio. Projeto participativo na produção do espaço público. Tese de Doutorado. São Paulo: FAUUSP, 2005. Cap. IV

175. A equipe contava com a participação das arquitetas Nagirley Kessin e Fany Galender, do Arq. Raul Pereira, da profa Nídia Pontuschka (Faculdade de Educação da USP), prof. Vladimir Bartalini e profa Vera Pallamin (FAUUSP). compostas por professores, consultores, alunos e interessados nos problemas a serem abordados trabalhavam, de forma concentrada e intensa, propostas que trouxessem soluções inovadoras e criativas às questões apresentadas. No dia e na hora combinados para término dos trabalhos, uma charrette (carrinho), passava pelas portas das salas onde as equipes interdisciplinares trabalhavam e recolhia as propostas. Esse método de trabalho de imersão ficou conhecido como charrete. ${ }^{174}$

A metodologia já havia sido utilizada no Canadá e foi trazida ao Brasil por Cordeiro e Boucinhas para utilização em uma dinâmica para essa mesma disciplina "Estúdio da Paisagem”, no ano de 2000. Naquela época, o objetivo era a reurbanização da Favela Pintassilva, localizada em uma área próxima à represa Billings, na cidade de Santo André.

Além do meio acadêmico, representado por professores e alunos da disciplina, o processo participativo de concepção envolveu moradores locais e funcionários da prefeitura, que seriam responsáveis pela viabilização do projeto do parque.

A dinâmica contou ainda com a consultoria de especialistas em temas pertinentes ao projeto, como vegetação, geografia, pedagogia, saneamento e recursos hídricos ${ }^{175}$. Teve também a participação do arquiteto norte americano Henry Sanoff, professor universitário na Carolina do Norte e especialista em processos participativos. Ele auxiliou no desenvolvimento de metodologias para a realização de oficinas com a população local durante a disciplina. Segundo Boucinhas, a metodologia proposta por Henry mostrou-se um tanto distante da realidade brasileira, não tendo promovido a integração adequada dos participantes.

As reuniões com a comunidade foram realizadas na Escola Municipal de Ensino Fundamental (EMEF) Rogê Ferreira, em área contígua ao parque proposto, e contava com a presença de seus alunos. Os resultados dos trabalhos da disciplina foram apresentados nessa escola, em um evento que reuniu, além dos seus próprios alunos, técnicos da prefeitura, a população local - inclusive lideranças comunitárias - alunos de outras escolas da região, a imprensa, subprefeitos e a Secretária Municipal do Meio Ambiente naquela época, Stela Goldenstein. 
Dentre as principais proposições das quatro equipes participantes do projeto, pode-se destacar: a valorização das áreas alagadiças do parque por meio de caminhos palafitados que as atravessassem, a recuperação dos seus recursos naturais, a criação de mirantes aproveitando os diversos enquadramentos visuais interessantes da área e a proposta de não cercamento, de modo a criar pequenas praças que, por serem abertas, pudessem ser utilizadas inclusive à noite.

Finalizado o trabalho da pós-graduação, o projeto permaneceu algum tempo parado devido à não priorização pelos órgãos públicos responsáveis. Tal situação só começaria a ser revertida por iniciativa dos moradores da região, que se tornaram mais conscientes da importância daquele espaço livre. Devido ao trabalho anteriormente realizado, decidiram reivindicar mais enfaticamente a área perante o Poder Público.

Uma parte significativa do processo de conscientização e reivindicação do parque foi realizado pela professora Márcia Penha, que lecionava Geografia na EMEF Rogê Ferreira. Por meio do trabalho com seus alunos, ela e vários outros professores buscaram manter em pauta a discussão a respeito do parque, levando-a indiretamente para a casa dos moradores, aproveitando-se do potencial da escola como polarizador social.

A adaptação inicial das idéias propostas na charrette foi realizada com a elaboração de uma síntese, quinze dias depois da apresentação dos trabalhos. Essa adaptação foi realizada por técnicos do DEPAVE em trabalho conjunto com os alunos da disciplina da pós-graduação e com a participação de 35 representantes da comunidade trazidos pela professora Márcia. O trabalho, que subdividiu o parque em onze áreas, durou três semanas e foi divulgado em exposição itinerante por escolas do entorno do parque, juntamente com as quatro propostas da charrette.

Embora já estivesse nos planos do DEPAVE transformar o local em parque, não houve interesse imediato na continuidade da obra. Nesse período de indefinição, Penha promoveu uma visita com seus alunos ao DEPAVE, com objetivo de solicitar a viabilização do parque

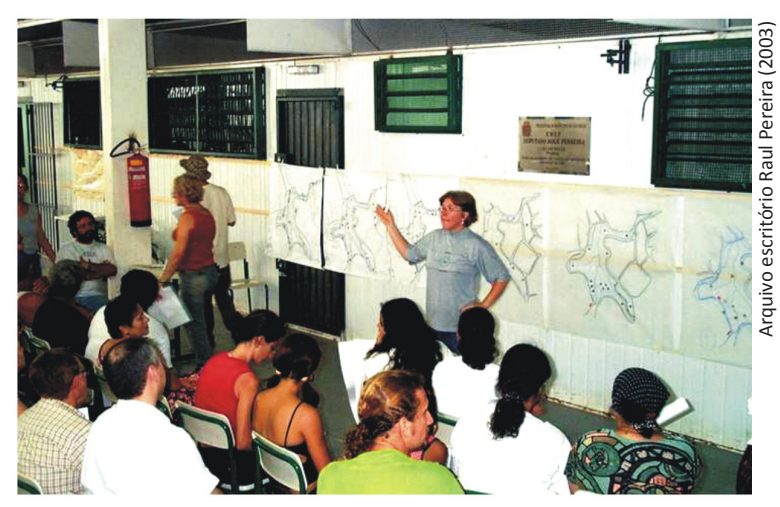

Profa. Márcia Penha discute as propostas para 0 parque na Escola Municipal Rogê Ferreira. 


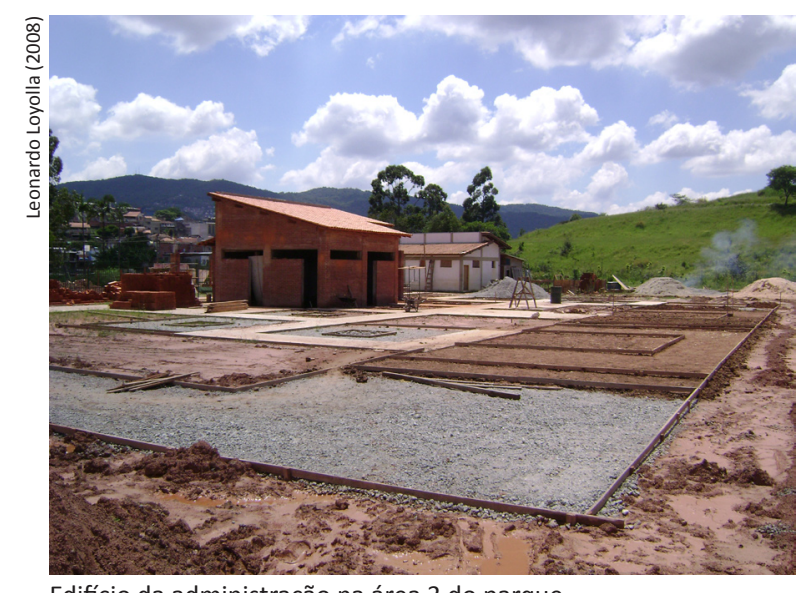

Edifício da administração na área 3 do parque.

Plantio inadequado de mudas em área do parque devido às ações fragmentadas para execução

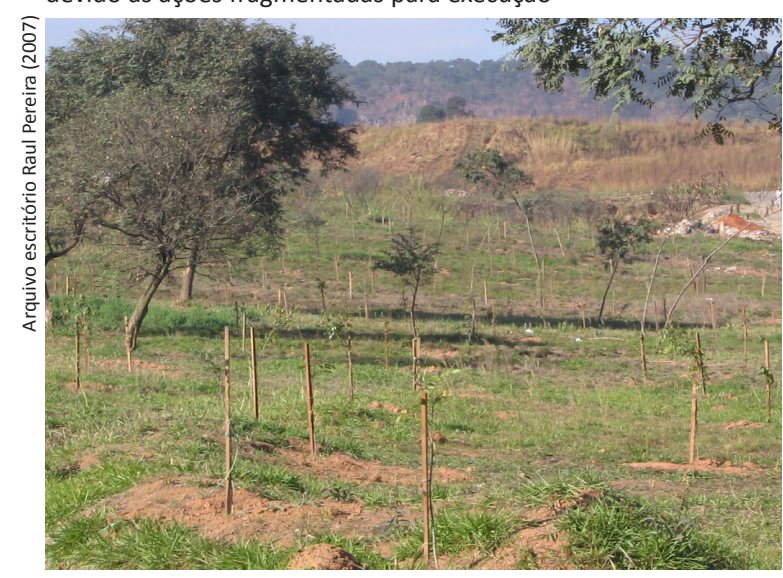

junto ao então Secretário Municipal do Meio Ambiente, Adriano Diogo. Somente após sucessivas reivindicações e aparentemente com o peso importante de razões de cunho político, buscou-se a viabilização do projeto. A partir desse momento, devido à falta de recursos da prefeitura, as compensações ambientais passaram a desempenhar papel importante.

O anteprojeto foi deixado ao encargo do escritório do arquiteto-paisagista Raul Pereira, que também havia participado da charrette. O programa final do projeto previu quadras esportivas, campo de futebol, playgrounds, passarelas e deques de madeira fazendo a integração do parque e das áreas alagadiças, recuperação da mata existente, integração das áreas propostas por alamedas arborizadas, além de edificações para abrigar um centro de educação ambiental, centro de convivência, administração, sanitários e vestiários. Os setores de números 1, 3, 4 e 5 seriam cercados e abrigariam a maior parte dos equipamentos de maior porte, como quadras, edificações e playgrounds. As demais áreas funcionariam como pequenas praças com áreas de estar abertas à comunidade, como havia sido previsto pelas equipes da charrette.

A execução do projeto tornou-se dependente de um fluxo descontínuo de recursos captados lentamente por meio de TCAs. Esse processo resultou em ações dispersas, nas quais algumas áreas já executadas (caso do setor 02 e partes do 03) conviveriam com outras que sequer haviam sido detalhadas.

Dentre as áreas executadas, podem-se citar interessantes contrastes entre aquilo que foi concebido no papel e aquilo que a realidade encarregou-se de adaptar. É o caso da Área 1, setor de implantação do parque no qual se localiza a EMEF Rogê Ferreira e um campo de futebol existente.

O campo de futebol - tradicionalmente consolidado como equipamento de lazer naquela região - possuía também a função de resguardar importante enquadramento visual do parque e da paisagem do entorno, constituindo um dos escassos exemplos de vista privilegiada em meio ao constante avanço da malha urbana em direção à Serra da Cantareira. 
Devido à priorização da prefeitura em uma época de véspera de eleições e à dificuldade de diálogo entre os órgãos responsáveis pelos espaços livres e pelos edifícios públicos institucionais, projetou-se uma nova escola no terreno. A nova construção visava substituir as precárias instalações que abrigavam a EMEF Rogê Ferreira, executadas na gestão Celso Pitta e conhecidas popularmente como "escolas de lata".

Conscientes da necessidade de preservação daquele trecho como espaço livre público, alguns moradores locais, juntamente com Cordeiro, Boucinhas e Penha, estabeleceram diálogos com órgãos públicos visando a negociação do local de implantação da escola. Segundo Boucinhas, na véspera do segundo turno das eleições municipais, foi realizada às pressas uma reunião com representantes do Poder Público e alguns poucos moradores visando decidir o destino da escola. Representantes do Departamento de Edificações da Prefeitura (EDIF) apresentaram a área do parque como única alternativa para receber a construção da nova escola. Além disso, foi exposto que a empreiteira para execução da obra já havia sido contratada e o início da obra seria imediato. Diante de tais pressões, foi aceita a execução da escola em área prevista para o parque, cuja finalização ocorreu no ano de 2006.

Como já foi visto anteriormente, a priorização de equipamentos públicos institucionais em detrimento de espaços livres públicos não constitui novidade no município de São Paulo. Esse é um dos fatos que justificam a carência dessas áreas na cidade.

Em que pese à necessidade de implantação de um equipamento urbano de melhor qualidade, sobretudo quando voltado à educação, poderia ter sido levado em conta um estudo que envolvesse outras possibilidades de locação do mesmo, visando à preservação daquele importante referencial da paisagem. Foi sugerida, inclusive, a implantação do edifício sobre pilotis de modo a preservar o enquadramento visual da área. Nenhuma dessas sugestões foi acatada.
Edifício da Escola Municipal Rogê Ferreira, construído em substituição à "escola de lata" em área pertencente ao parque.

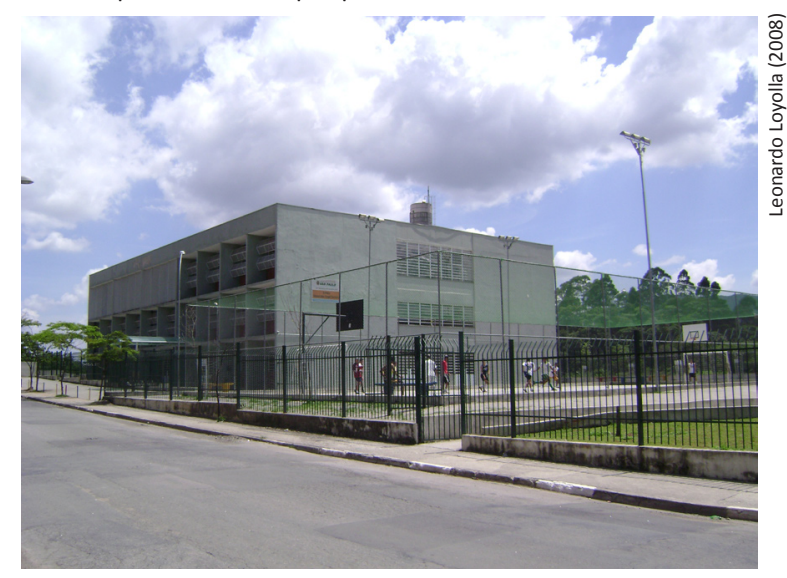


Outro caso interessante ocorreu na área 2 do parque, conhecida como "ferradura" devido ao formato da rua que a delimita, quando visto em planta. Nessa área se localiza uma das nascentes de córrego existentes no parque. Além disso, o local possui importante enquadramento da paisagem graças à sua conformação de mirante. Face à escassez de cobertura arbórea no local, foi previsto o plantio de árvores provenientes de TCA, com caixas que conformavam bancos voltados para a paisagem. Foram especificadas copas mais generosas, visando sombreamento. Por razões desconhecidas, foram plantadas palmeiras no local, em substituição às árvores previstas, desconsiderando a intencionalidade da equipe de projeto.

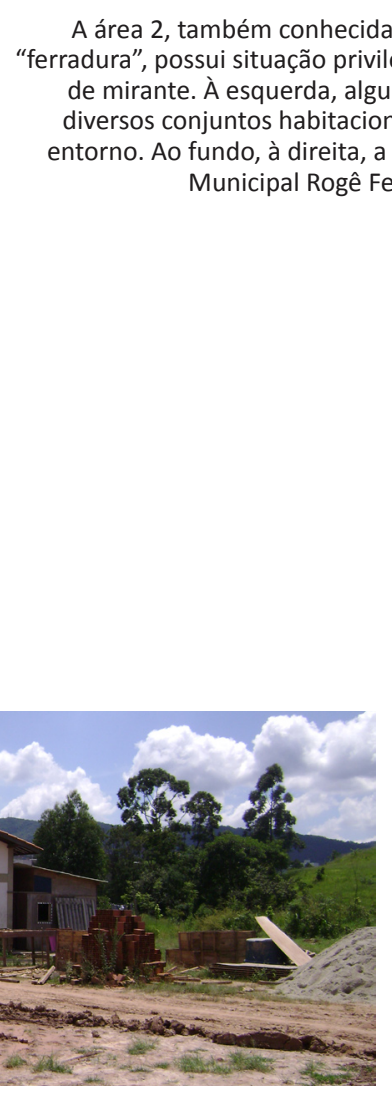

176. Entrevista realizada em 15.03.2007

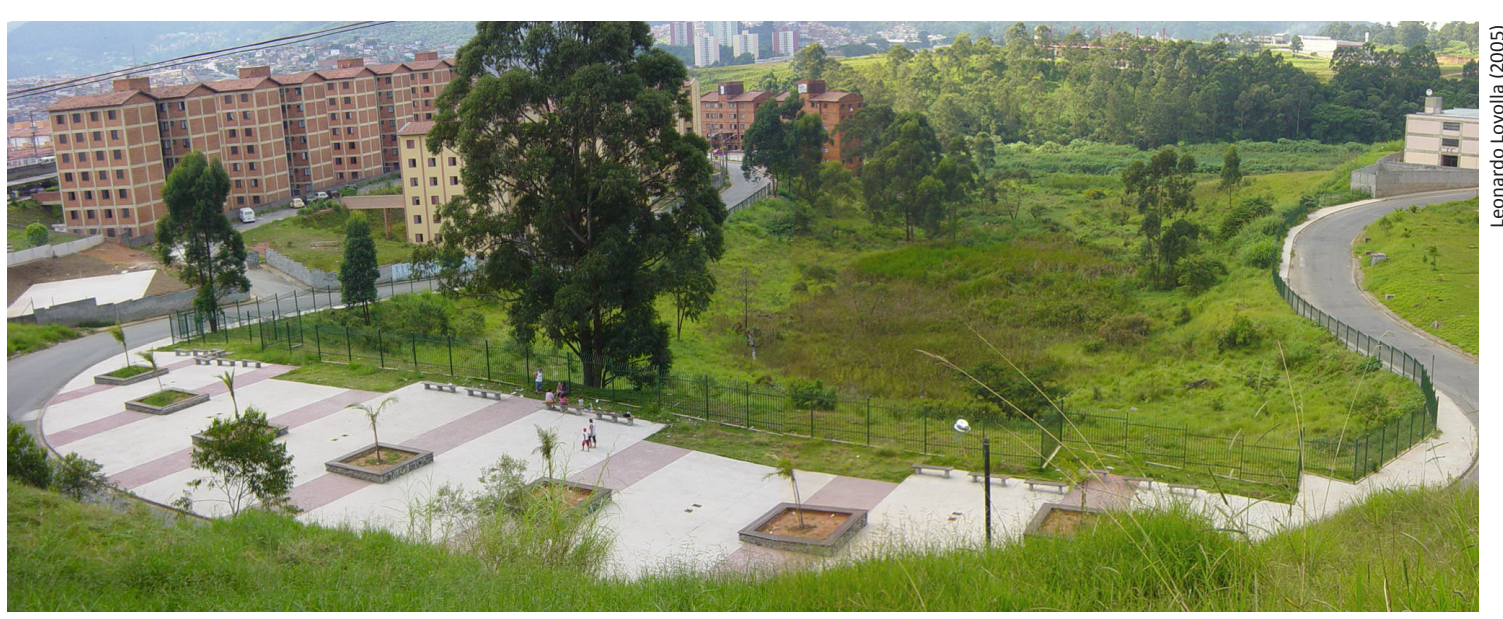

Problema semelhante ocorreu na implantação de vestiários na área 3 do parque. Em decorrência de um embate com lideranças locais relacionadas ao narcotráfico, ocorreu uma negociação (não-oficial) com a prefeitura relativa à mudança da locação dos equipamentos, de modo a não interferir em seus interesses. A alteração de projeto foi acatada pelo Poder Público, de modo a não criar mais um elemento que atravancasse o já tortuoso processo de execução do parque. Este tipo de adaptação à realidade dos usuários daquele espaço dificilmente seria cogitada no projeto do papel, sendo só percebida ao travar-se contato com a (muitas vezes dura) realidade daqueles que vivem naquele local. 
A Gestão Serra/Kassab promoveu continuidade ao processo de viabilização do parque. No ano de 2006, após um tortuoso e demorado processo de aprovação iniciado na Gestão Marta Suplicy, e após a execução parcial de algumas partes, o projeto executivo foi inteiramente liberado pelo DEPAVE. Essa situação peculiar, na qual a execução da obra corre paralelamente ao seu projeto, é um dos problemas ainda inerentes ao uso de compensações ambientais como forma de custeio de projetos de espaços livres. Tal fato dificultou e delongou bastante a elaboração do projeto, pois exigiu inúmeras revisões por parte dos envolvidos.

No fim do ano de 2006, a obra seria retomada. A exemplo do que ocorreu com o Parque do Cordeiro, os recursos para a finalização da obra passaram a vir do orçamento do próprio DEPAVE, e não mais de compensações ambientais. Inicialmente foi realizado o cercamento do parque com gradis e alambrados. A Arq. Célia Kawai ${ }^{176}$, diretora do DEPAVE entre os anos de 2006 e 2007 relata que a realização dessa obra apresentou problemas devido ao furto da parte dos alambrados, mais frágeis. Tal fato exigiu a colocação de um novo fechamento. Desta vez foram utilizados gradis, mais resistente às ações de furto. Até o ano de 2008, a execução das obras do parque ainda não havia sido finalizada.

Ao analisar o caso do Parque Pinheirinho D’Água, merece destaque a ampliação do embrionário processo de conscientização dos moradores a respeito da importância do parque. A presença do meio acadêmico exerceu um papel importante como ponte de ligação entre moradores e órgãos públicos, fornecendo insumos tanto para a concepção do espaço quanto para a reivindicação de recursos para viabilização do mesmo.

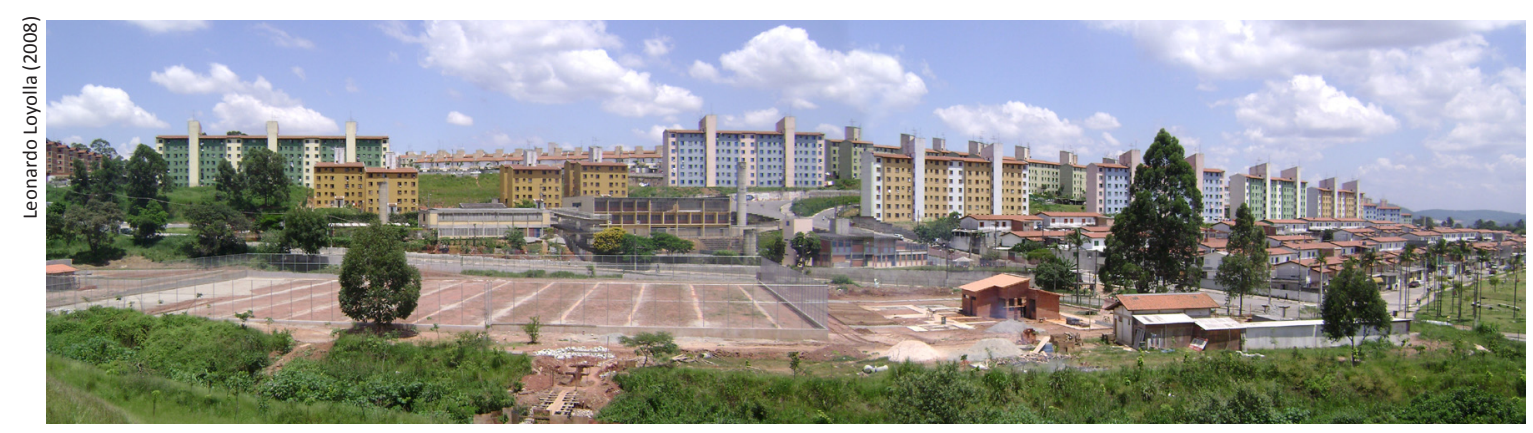

Vista geral da área 3 , em fase de execução no ano de 2008 


\section{Parque Jacintho Alberto}

Localizado no distrito de Pirituba, região noroeste do município, o parque situa-se entre a linha ferroviária que liga São Paulo a Jundiaí e a Rua Talófitos, via que inicia-se na Av. Raimundo Pereira de Magalhães, antiga Estrada de Campinas. A região possui uso residencial de baixa e média renda, predominantemente horizontalizado e pontuado por algumas torres. Também é ocupada por alguns galpões de uso industrial. $\mathrm{O}$ parque está próximo a dois outros espaços livres do bairro: os parques Rodrigo de Gasperi e Jardim Felicidade. O terreno, com $40.910 \mathrm{~m} 2$, possui relevo bastante acidentado, sendo dividido ao meio por um talude íngreme com alguma arborização.

Em 2001 começaram as reivindicações de moradores do entorno para dar uso ao terreno público sem uso específico na época. Originalmente, a área tinha sido prevista como praça pela prefeitura, mas população local desejava transformá-la em parque. Segundo o Arq. Caio Boucinhas, diretor do DEPAVE na época de início da concepção do projeto, os moradores alegaram que os parques tinham presença mais constante de funcionários para manutenção e vigilância, quando comparados às praças.

A viabilização do projeto teve importante participação da comunidade local, que foi mobilizada pelo objetivo comum de pressionar os órgãos públicos.

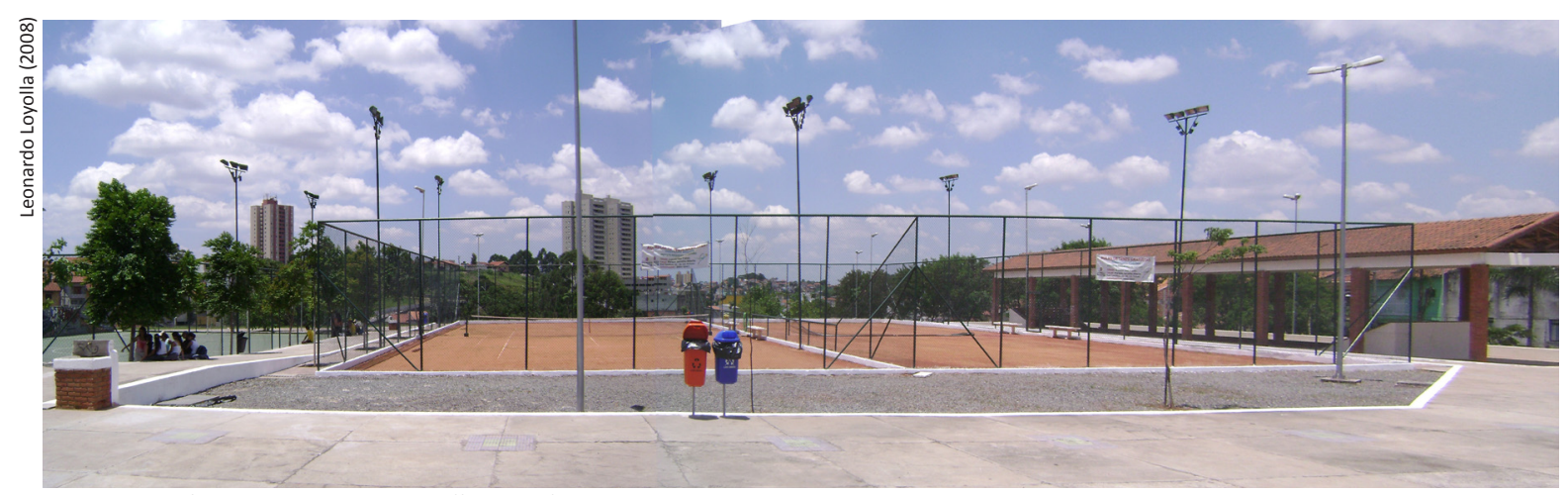

Quadras de tênis e cancha de bocha (à direita) na parte superior do parque
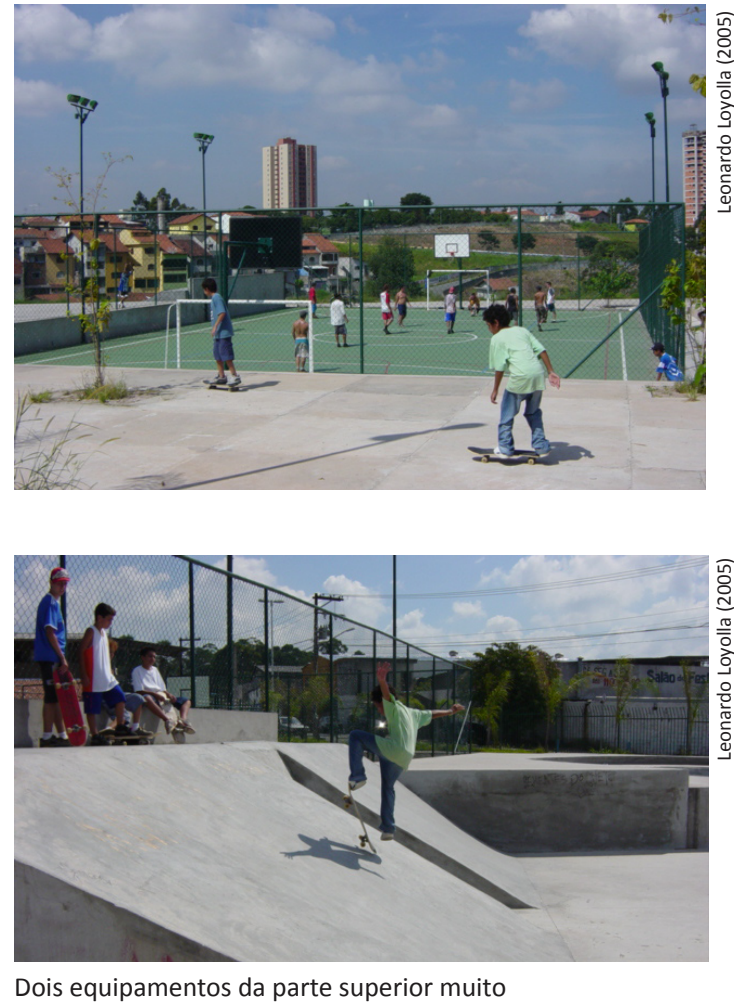

Dois equipamentos da parte superior muito utilizados pelos frequentadores do parque: quadra poliesportiva e pista de skate

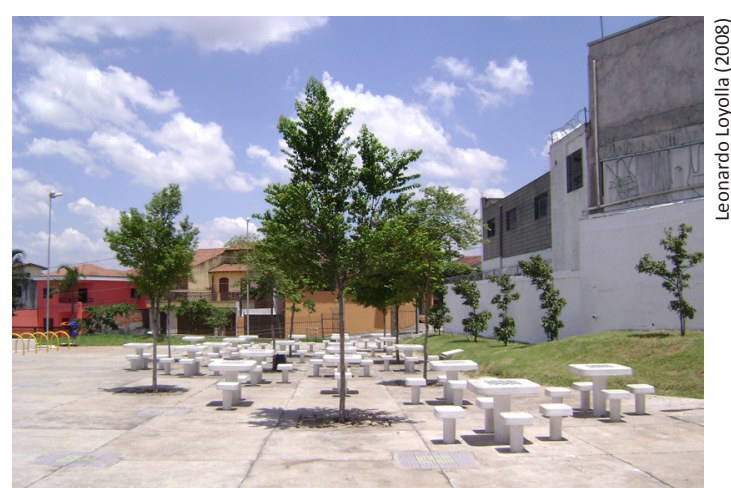

Área de estar com mesas para piquinique e para jogos 

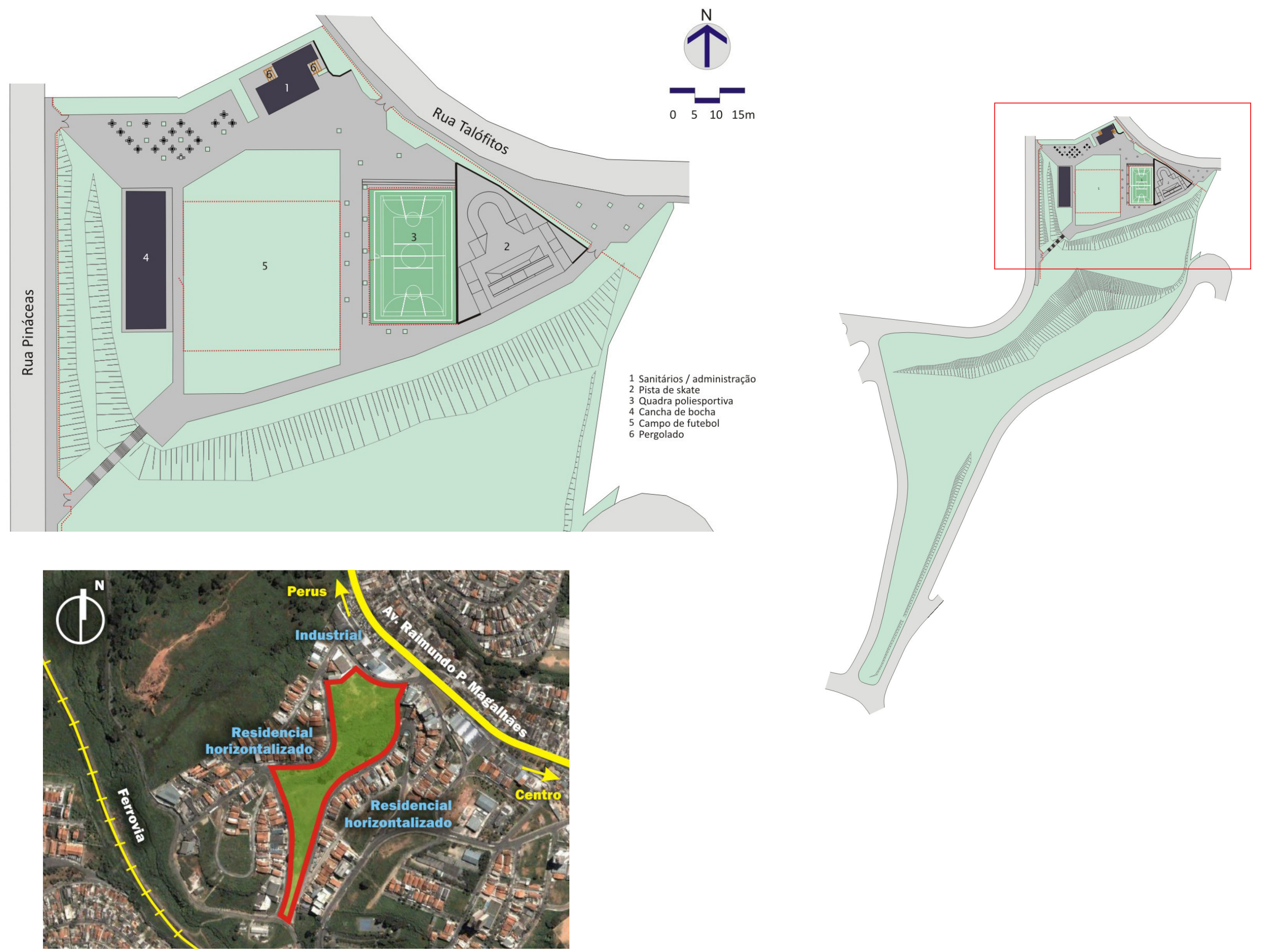

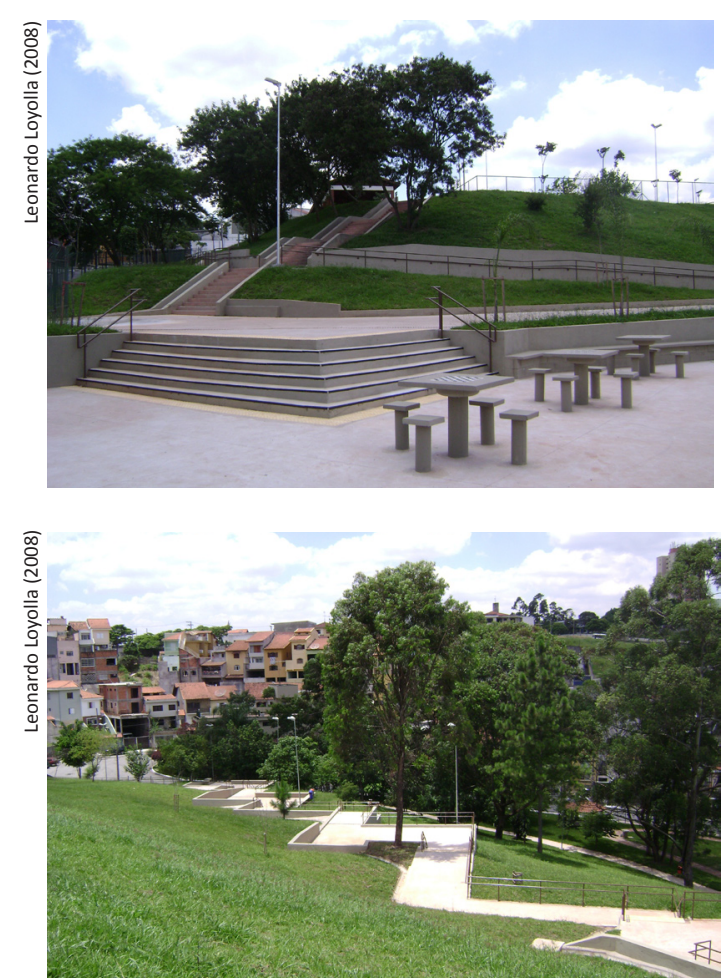

O íngreme talude que divide a parte superior e inferior do parque é vencido por patamares escalonados
A idéia de transformar a praça em parque não foi aceita inicialmente pelos técnicos do DEPAVE. A discussão colocou em pauta os limites das conceituações de parque e praça. Um dos elementos que caracterizam um espaço livre público do município de São Paulo como parque é o uso de fechamentos. No caso do Parque Jacintho Alberto, o cercamento $\mathrm{da}$ área era reivindicado pelos moradores como forma de consolidar atividades de lazer e ao mesmo tempo permitir que o uso intenso inibisse a ação do narcotráfico naquele espaço.

Apesar da relutância inicial, o projeto foi iniciado. $\mathrm{O}$ estudo preliminar, realizado pela equipe do DEPAVE, previu quadras esportivas, cancha de bocha, pista de skate, mesas para jogos, playground, edifício administrativo, sanitário, vestiário e pista de Cooper. A sugestão de utilizar uma quadra de tênis e mesas para jogar xadrez veio de professores de uma escola local, que desejavam tornar estas duas atividades mais populares naquela região.

O detalhamento do projeto foi realizado pelo escritório do arquiteto-paisagista Raul Pereira. O custeio do projeto do parque e os recursos para execução da obra vieram de compensações ambientais provenientes de empreendimentos de torres residenciais construídas por cooperativas no entorno. Como o montante de cada obra não era suficiente para o custeio

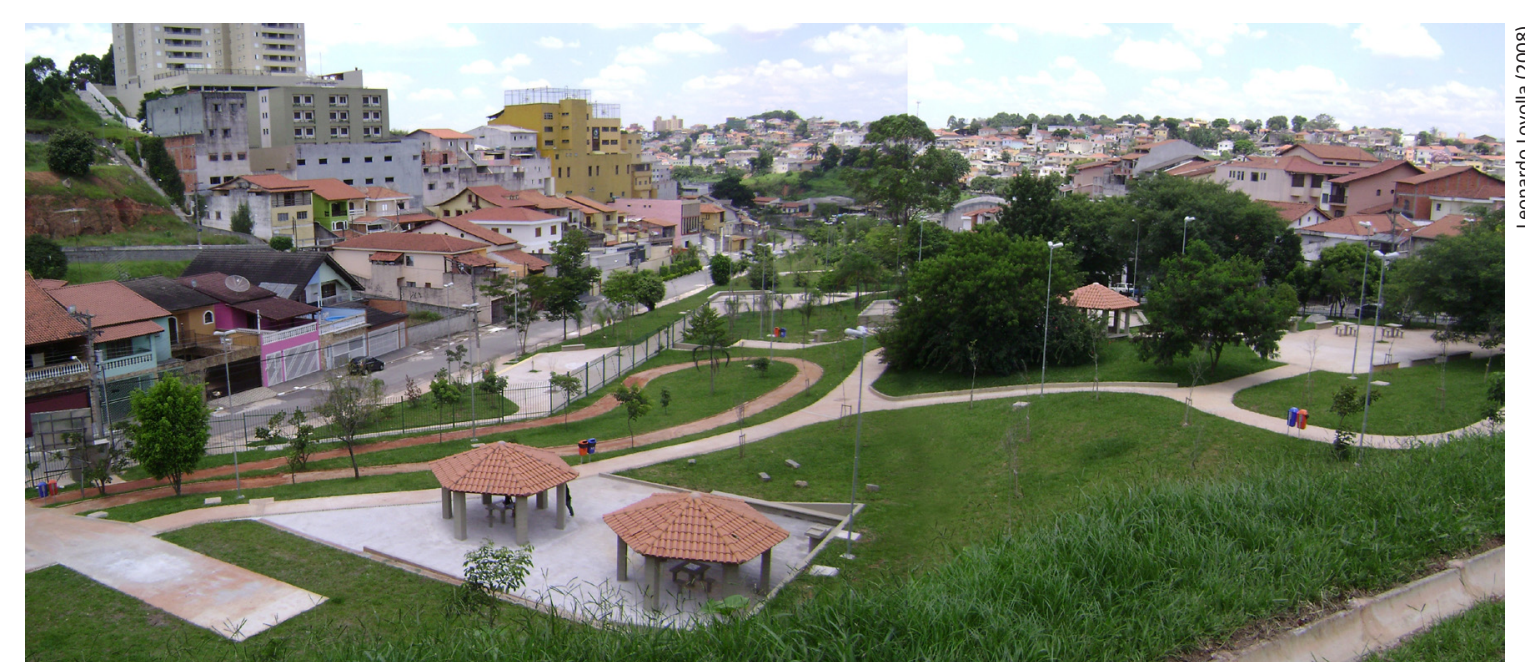

Vista geral da parte inferior do parque: pista de caminhada e quisosques 
das partes necessárias ao parque, foi necessário o agrupamento desses valores. A empresa responsável pelo maior valor gerenciou os montantes das outras compensações.

Essa soma foi suficiente para executar a porção superior do parque. Além de ser fechada com gradis e receber o plantio de algumas árvores, nela foram implantadas quadras esportivas, edifício administrativo, cancha de bocha, pista de skate e mesas para jogos. A área correspondente à quadra de tênis foi delimitada com alambrado, mas não foi utilizado piso de saibro, sob argumento da necessidade de freqüentes manutenções. Foi deixado piso em terra batida, no qual tem crescido grama. A data de inauguração da primeira parte do parque foi 31 de Dezembro de 2004, último dia do mandato de Marta Suplicy na prefeitura do município.

Dois anos se passariam sem a retomada da obra, até que no fim de 2006 foi realizada licitação para executar a parte final. Os recursos para esse trecho - a exemplo de outras obras de parques públicos custeados por TCAs e retomados nessa época - não vieram mais de compensações ambientais. Desta vez, utilizaram-se verbas provenientes de recursos orçamentários do próprio DEPAVE. Em 26 de janeiro de 2008 o parque foi inaugurado em sua totalidade, incorporando ao programa de usos quiosques, pista de caminhada e áreas de estar.

O parque tem sido bastante utilizado pela população local desde a inauguração de sua primeira etapa, sobretudo a pista de skate e a quadra esportiva. Desde 2007, as quadras de tênis são usadas regularmente para aulas promovidas em parceria entre empresas locais e a Subprefeitura de Pirituba. Alguns moradores têm auxiliado a cuidar dos trechos do parque próximos às suas casas, contribuindo para protegê-lo contra ações de vandalismo. 


\section{Parque da Vila Prudente}

Localizado no bairro de Vila Alpina (Subprefeitura de Vila Prudente, zona leste paulistana), o parque possui como entorno uma área verticalizada em expansão, ocupada principalmente por classe média desde a década de 1980.

O terreno do parque é contíguo ao Centro Esportivo Municipal Arthur Friedrich, embora não haja interligação entre os dois. A área também é delimitada pelo cemitério e crematório da Vila Alpina em um dos lados, e por uma escola do Serviço Nacional de Aprendizagem Industrial (SENAI) no lado oposto. Antes da implantação do parque, o local já possuía um bosque significativo de eucaliptos, em sua porção próxima à divisa com o cemitério. O relevo da área alterna platôs consideráveis - suficientes para implantar diversos equipamentos de lazer - e locais com declividades maiores, vencidas por escadas.

Iniciadas em 2002, as obras do parque foram concluídas no final do ano de 2004, juntamente à entrega da primeira fase do Parque Jacintho Alberto e ao fim do mandato de Marta Suplicy na prefeitura de São Paulo. A implantação foi dividida em duas partes, sendo que a segunda, até o ano de 2008, não havia sido concluída. Na primeira etapa foram executados: pista de caminhada, playgrounds, áreas de estar com mesas e bancos, pérgola, estacionamento, um edifício administrativo e guarita na portaria.

O nome oficial do parque (Parque Ecológico Professora Lydia Natalízio Diogo), homenagem à mãe do então Secretário do Meio Ambiente, simboliza o papel fundamental de Adriano Diogo na articulação política para viabilização do parque. Diogo, que anteriormente fora vereador, possuía sua base eleitoral na zona leste paulistana.

O edifício administrativo não chegou a ser usado para esse fim, tendo sido transformado em posto policial poucos meses depois da abertura do parque. A existência do posto auxiliou a reduzir problemas iniciais apontados pelos moradores locais, tais como narcotráfico e vandalismo

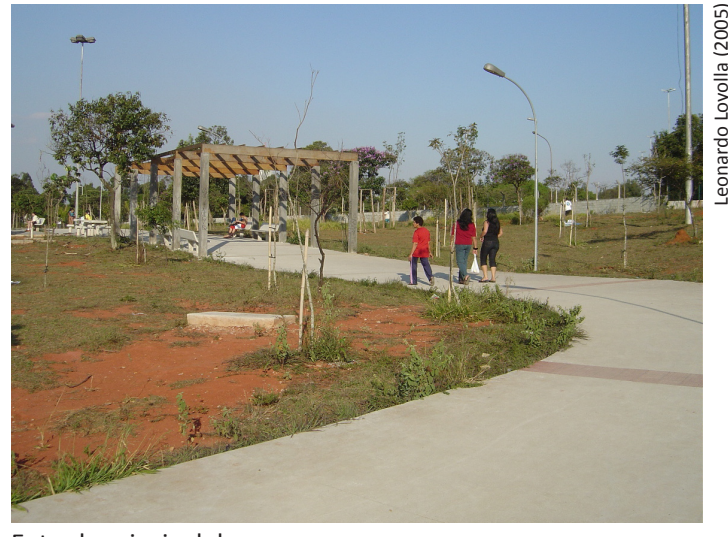

Entrada principal do parque

Edifício previsto para administração e utilizado como posto policial

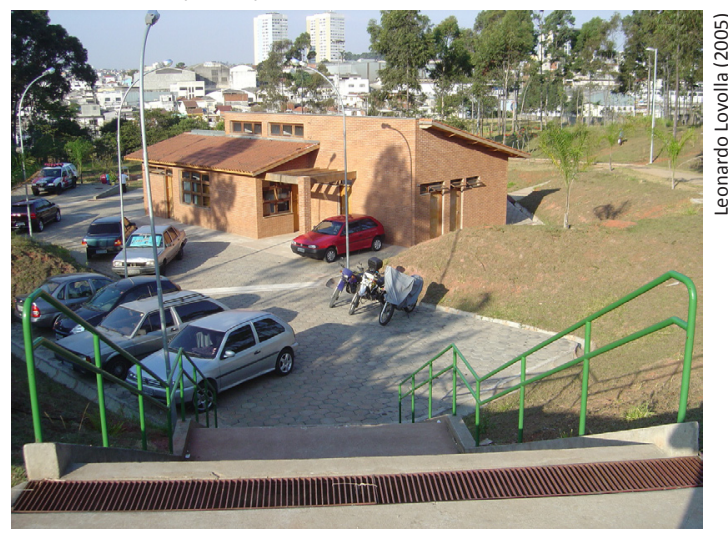


2 Centro Esportivo Municipal Artur Friedrich

3 Crematório da Vila Alpina

4 Guarita

5 Pista de Cooper

7 Estacionamento

8 Posto policial (antiga administração)

9 Campo de Futebol
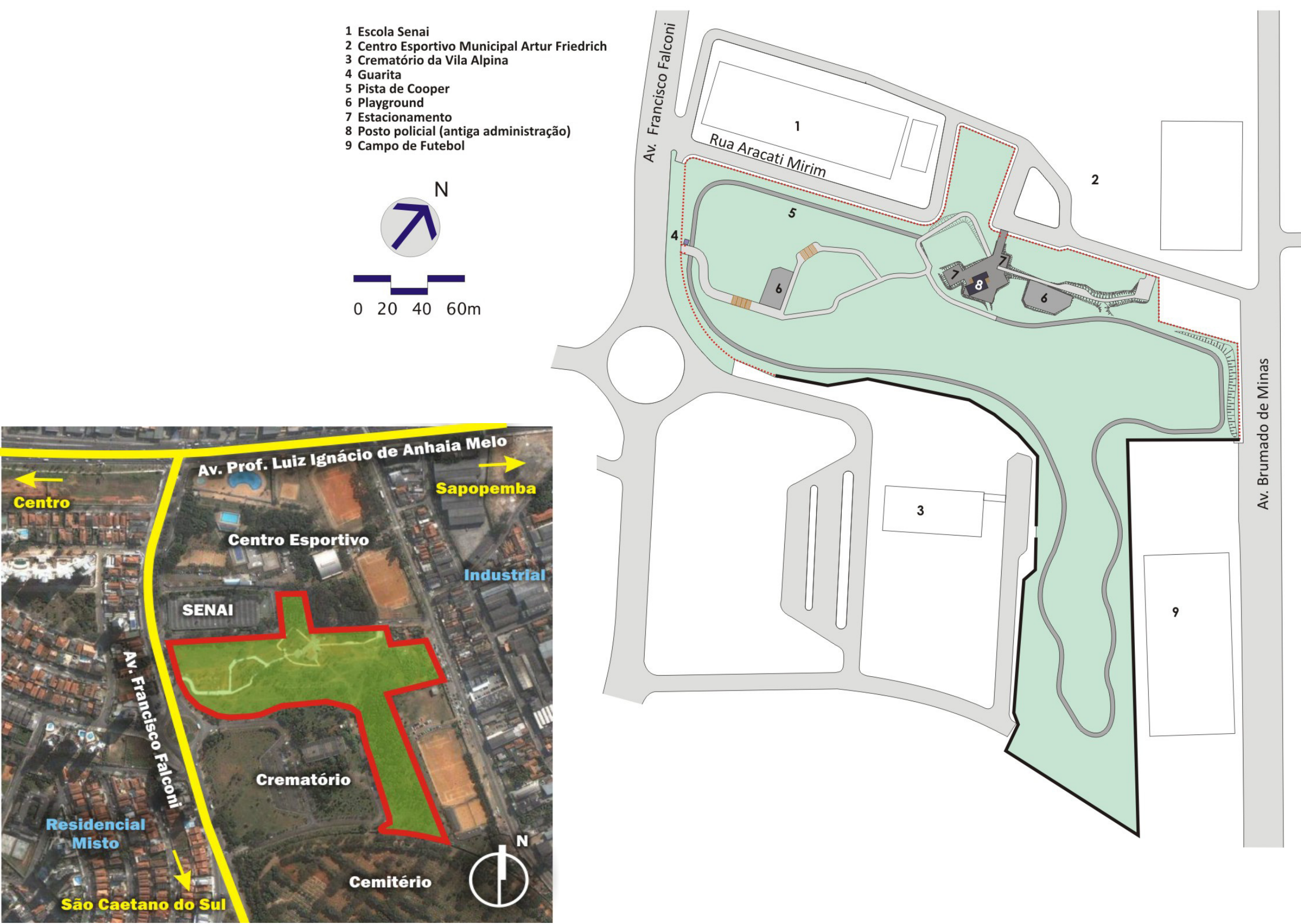


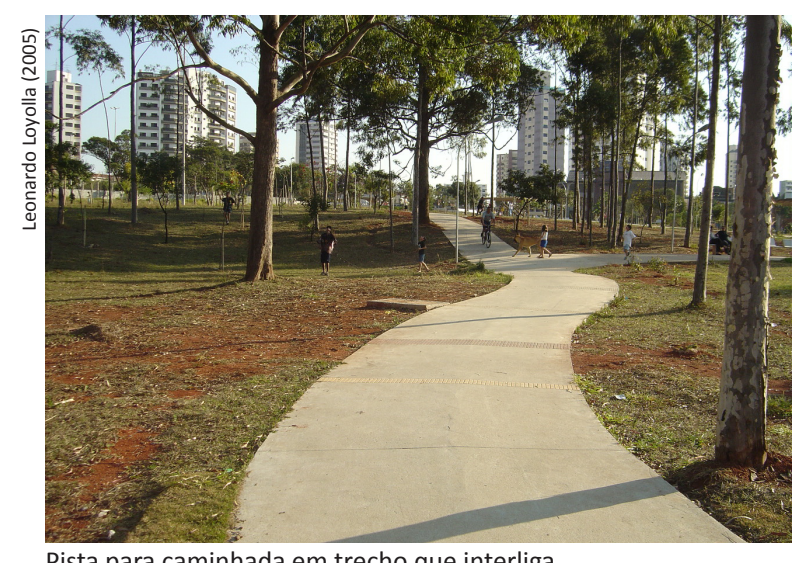

Pista para caminhada em trecho que interliga a entrada do parque ao Posto Policial

Uso intenso pela população em gramado próximo à pista de caminhada

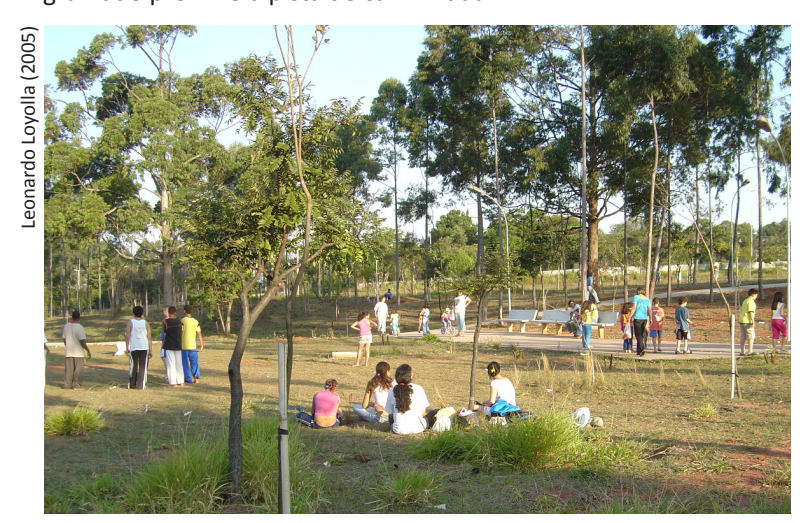

O parque foi executado em sua maior parte com recursos de compensações provenientes de empreendimentos residenciais e industriais da própria zona leste. Dos projetos de espaços livres recreativos custeados por compensações ambientais no município, este havia sido o único projetado integralmente pela equipe DEPAVE até o ano de 2008. Ao contrário dos parques Pinheirinho D'água e Cordeiro, o projeto do DEPAVE não apresentava participação ativa da população local.

O local é bastante utilizado pela população de todas as faixas etárias, adquirindo caráter de parque regional, em conjunto com o Centro Desportivo Municipal Arthur Friedrich.

A manutenção do local é mediana, existindo, por exemplo, vários casos de mudas mortas que foram repostas pela própria comunidade local, sem critérios específicos para plantio. 


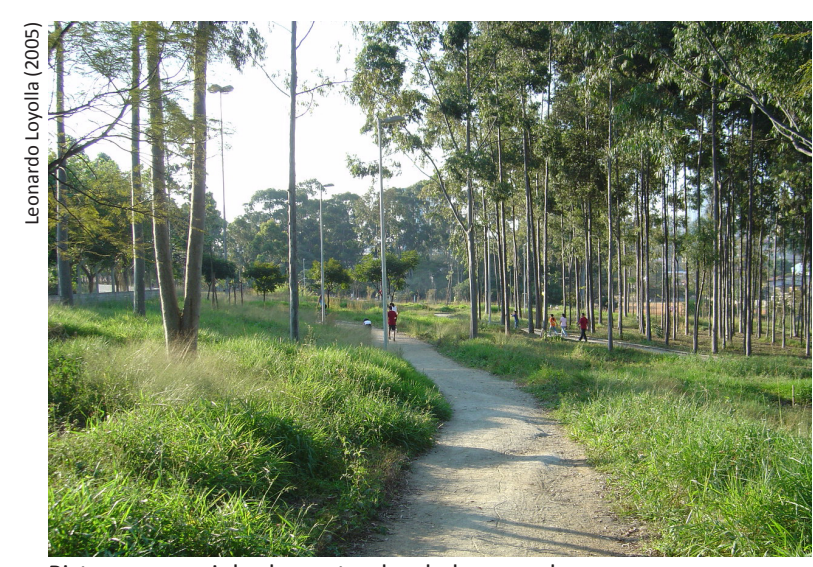

Pista para caminhada em trecho do bosque de eucaliptos na divisa com o Cemitério de Vila Alpina

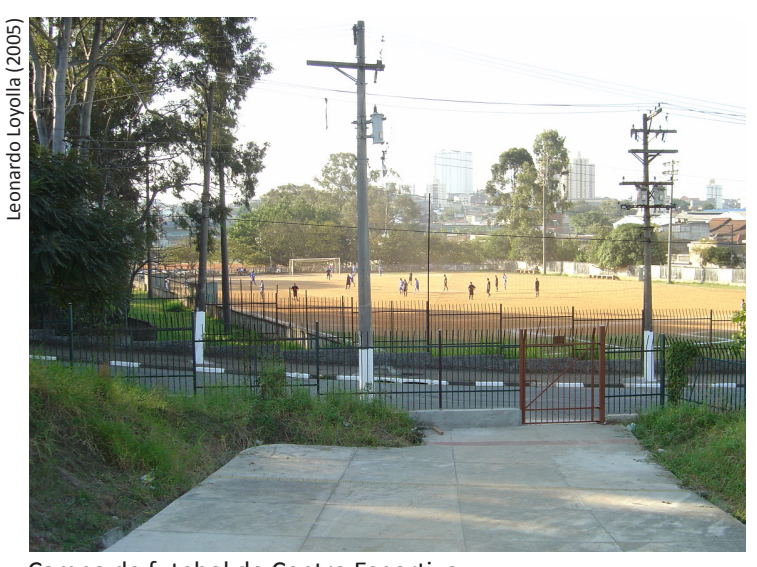

Campo de futebol do Centro Esportivo Arthur Friedrich visto a partir do parque.

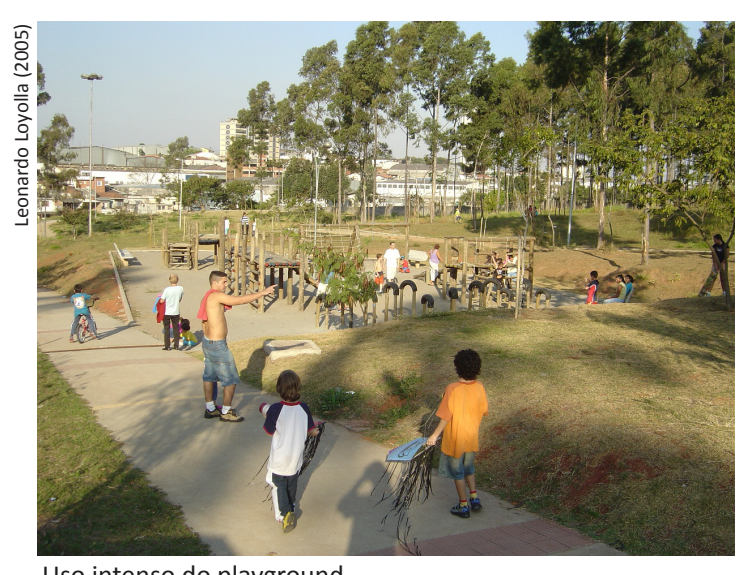

Uso intenso do playground próximo ao Posto Policial. 


\section{Praça Anna dos Santos Figueiredo}

Localizada no bairro Jardim Anália Franco (Subprefeitura Aricanduva/Vila Formosa, zona leste paulistana), a praça de $10.000 \mathrm{~m}^{2}$ é conformada pelo cruzamento da Avenida Regente Feijó com a Avenida Vereador Abel Ferreira. Ambas ligam o distrito de Vila Formosa à Avenida Salim Farah Maluf - que compõe o Mini Anel Viário Municipal. A Avenida Ver. Abel Ferreira, localizada em um fundo de vale, foi aberta em meados da década de 1980. O trecho contíguo à praça é fruto de obras de extensão mais recentes que a ligaram à Avenida Salim Farah Maluf no início da década de 1990. Diversos lotes ao longo de sua extensão ainda encontram-se desocupados.

O processo de ocupação do Jardim Anália Franco data do início da década de 1980, mas só intensificou-se durante a década de 1990. A área, antes composta por extensos lotes desocupados, sofreu grandes valorizações com a construção de diversos empreendimentos compostos por torres residenciais de alto padrão. Contribuiu para essa valorização a proximidade a um Centro Educativo, Recreativo e Esportivo do Trabalhador (CERET), inaugurado em 1974.

A qualidade presente dentro dos terrenos desses empreendimentos não se repete nas áreas externas a eles. Observa-se uso generalizado de altos muros para proteção, que conferem características bastante áridas ao entorno. A valorização do bairro foi consolidada com a construção de um Shopping Center na Avenida Regente Feijó em $1999^{177}$ e à implantação de um novo Campus da Universidade Cruzeiro do Sul (Unicsul) no ano de 2001.

A construção da praça está vinculada à implantação dessa universidade. O campus utilizou um terreno na Avenida Regente Feijó, ocupado por dois edifícios tombados pelo patrimônio histórico: a sede do antigo Sítio do Capão (utilizada pelo Regente Feijó) e o orfanato Lar Anália Franco (projeto do arquiteto Ramos de Azevedo datado de 1930). A área possuía significativa massa arbórea, retirada em parte para a execução das obras de ampliação da universidade, que também restaurou as edificações históricas. Foram necessárias diversas negociações com o DEPAVE para determinação da área a ser ocupada pelas obras e a proposição da praça como medida compensatória a estas.

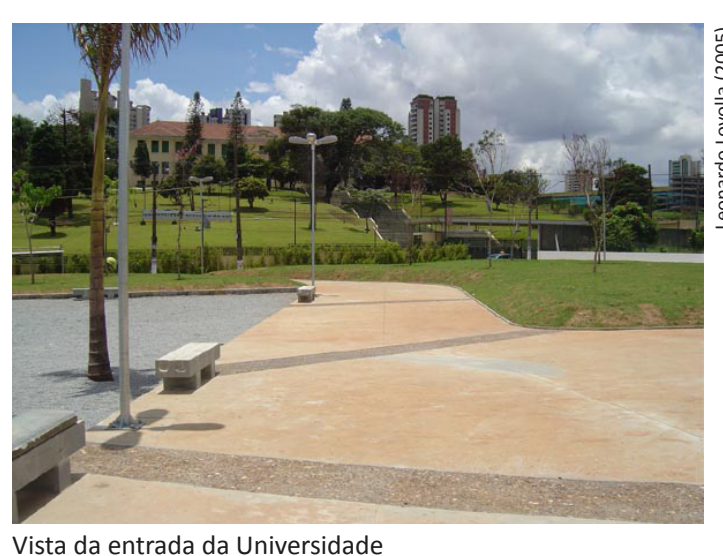

Cruzeiro do Sul a partir da praça

177. LIMA, E. ; PASSOS, I. Bairro de alto padrão. Conhecido por abrigar prédios de luxo e símbolo de status, o Jardim Anália Franco ganha um centro de compras com grifes famosas. Revista Veja São Paulo. 24 novembro 1999. 


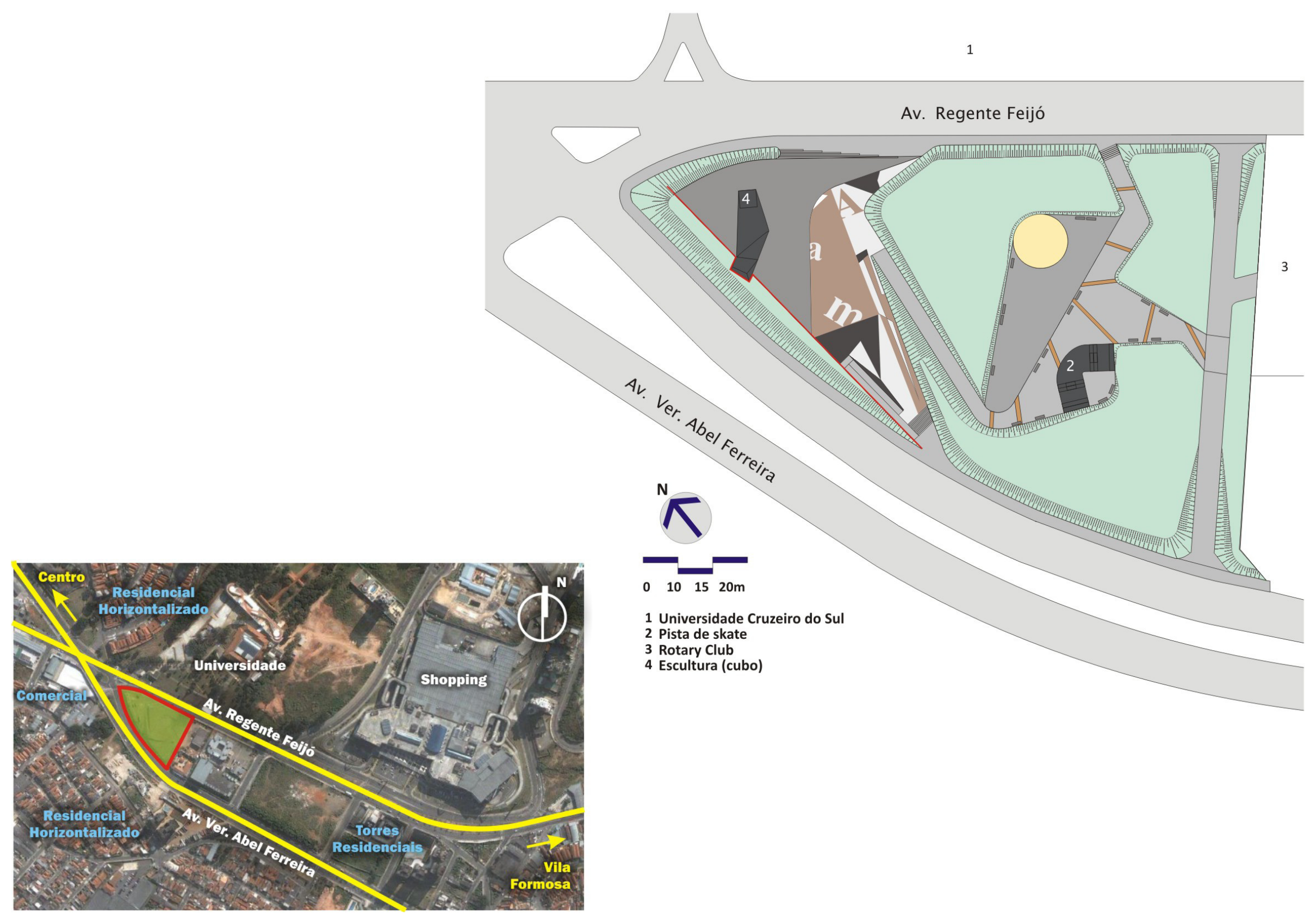




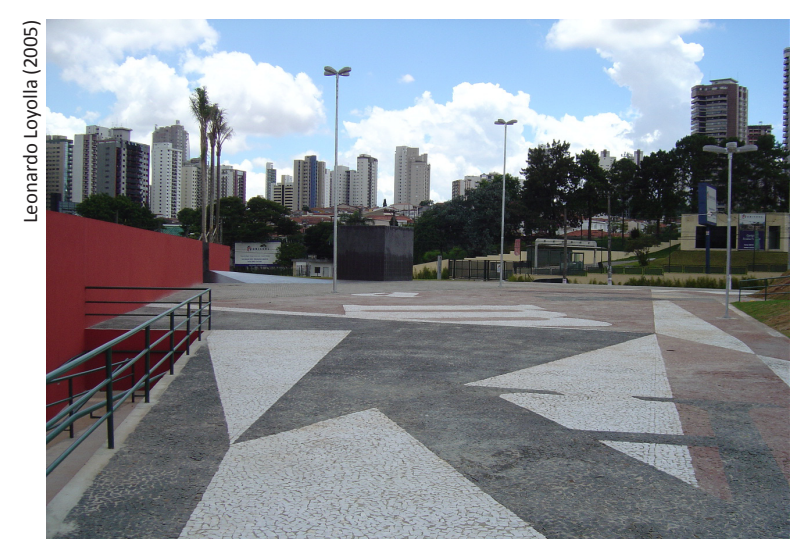

Desenho geometrizado de letras no piso em mosaico português fazem referência à universidade que custeou o projeto. Ao fundo, edifícios residenciais de alto padrão no entorno da praça.

Grande talude e empenas separam visualmente a praça do entorno. Vista a partir do cruzamento da Av. Regente Feijó e Ver. Abel Ferreira

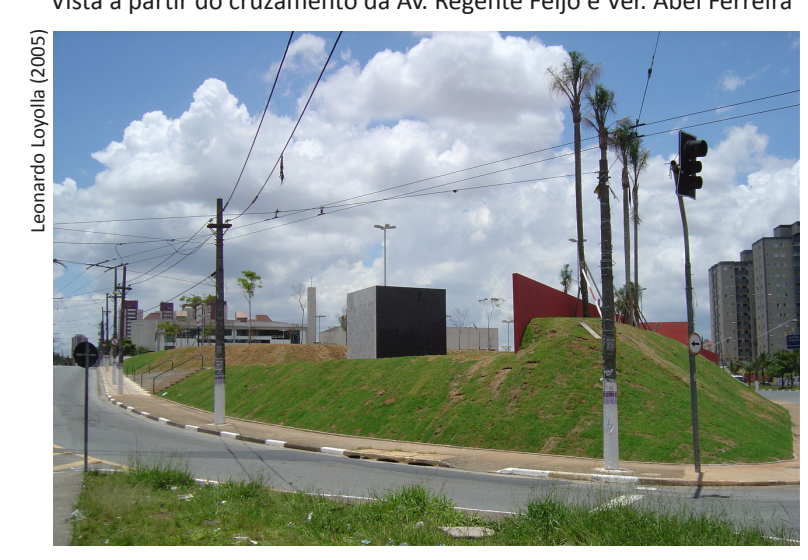

O projeto da praça, que se localiza em frente ao campus da Unicsul, foi realizado pelo escritório Kruchin Arquitetura. A mesma equipe profissional foi responsável pelo plano diretor e pelas edificações do campus. O programa do projeto era simples, envolvendo amplas extensões de piso, áreas de estar com bancos e uma pista de skate. O projeto, realizado em 2003, foi executado no final do ano seguinte.

A linguagem projetual, inspirada nas experiências européias, utiliza sofisticados desenhos de piso coloridos, formas geométricas, empenas e escadarias. $O$ traçado encontra-se bem mais vinculado ao projeto do campus do que à produção usual de espaços livres no município.

O terreno possuía declive substancial em direção ao cruzamento das avenidas que o conformam. Subvertendo a inclinação do terreno, foi criado um grande platô, arrematado por taludes e empenas com alturas superiores a 3,00m, voltadas para a Avenida Ver. Abel Ferreira. Tal recurso ajudou a atenuar o barulho provocado pelo intenso tráfego das avenidas do entorno. Mas por outro lado, associado à aridez das amplas áreas de piso utilizadas no projeto, contribuiu para provocar o isolamento da praça.

Concebida para ser uma "ante-sala" da universidade, a área possui uso bastante reduzido. Dentre seus poucos usuários, destacam-se grupos de skatistas que utilizam o único equipamento de lazer ativo existente na praça.

Pouco utilizada e sem vigilância específica, a praça sofre ações constantes de vandalismo, tais como pichação, quebra de equipamentos e da vegetação existente, encontrando-se bastante degradada no ano de 2008. 


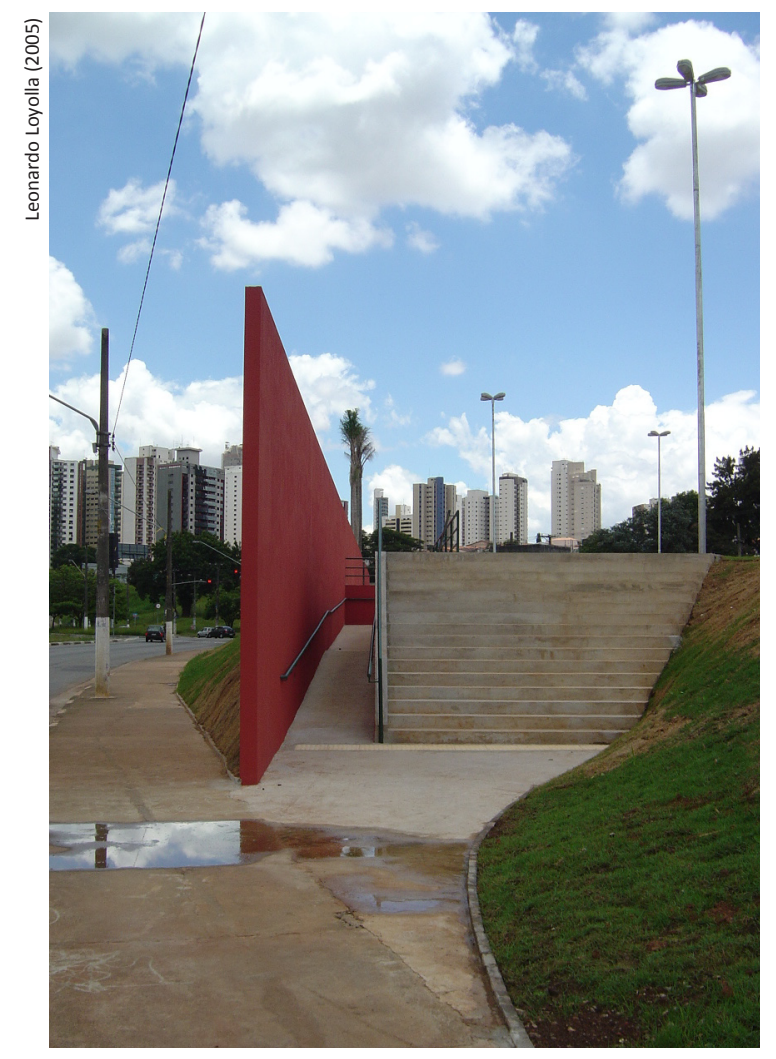

Fotos da praça em 2005, época de sua inauguração,

(à esquerda) e um ano depols (à direita). Exemplos da

degradação sofrida em curto espaço de tempo devido

ao vandalismo e à falta de manutenção.

Acesso à praça a partir da Av. Ver. Abel Ferreira. Grande empena isola o acesso em relação à via de grande movimento. A inserção da rampa no estreito vão entre empena e a escada, embora criativa, gera te opressiva ao cadeirante
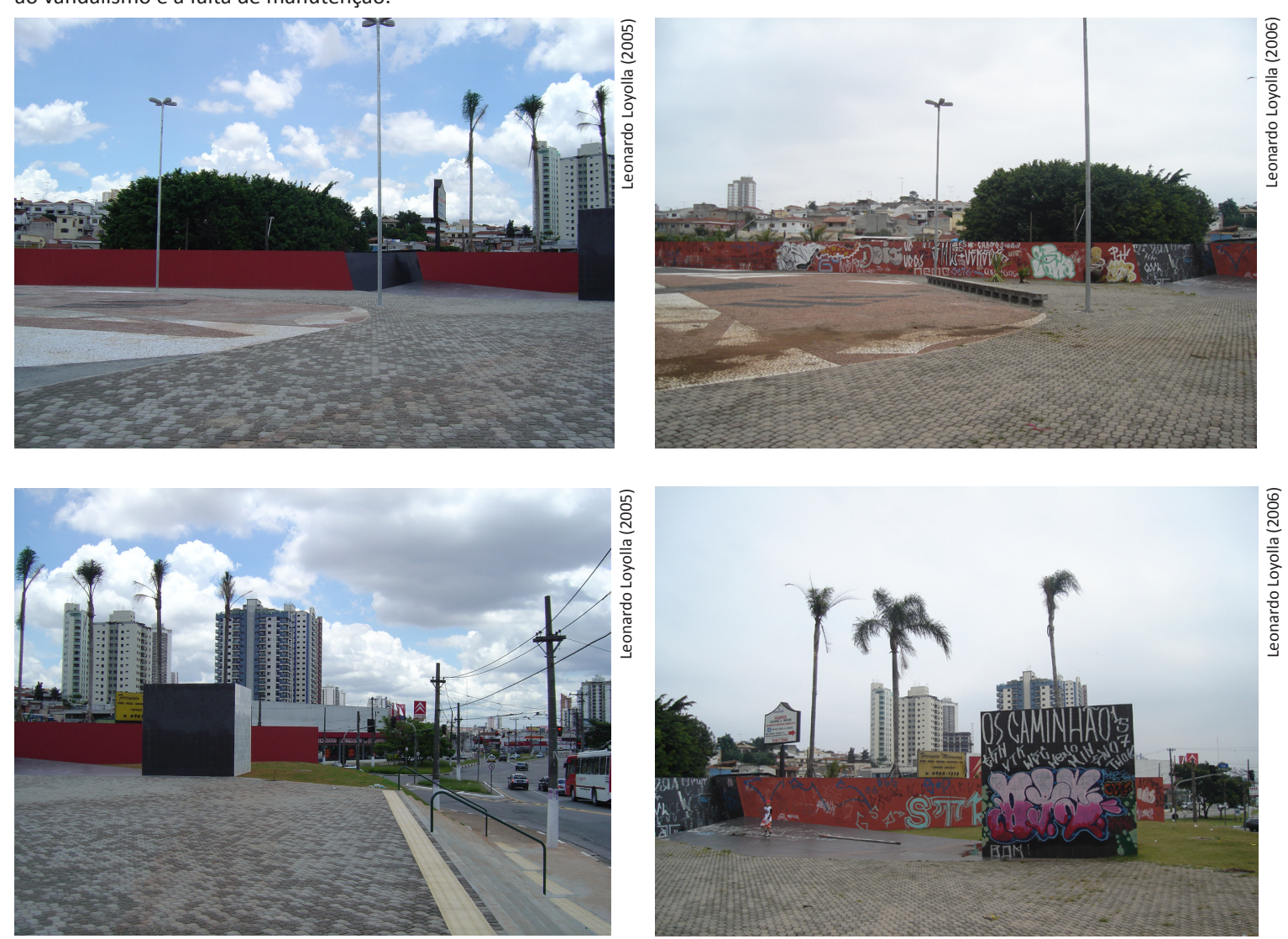


\section{Praça Silvio Romero}

Espaço livre bastante consolidado da zona leste paulistana, a Praça Silvio Romero apresenta vínculo estreito com a população do bairro do Tatuapé, desempenhando um papel de centralidade local. Constitui um espaço livre onde se sobrepõem diversos usos, dentre os quais merece destaque a Igreja Nossa Senhora da Conceição.

Sua configuração atual deriva de sucessivas reformas sobre um desenho de caráter tradicional, que se adequou às demandas funcionais surgidas ao longo dos tempos. A iniciativa de reformá-la decorreu, em boa parte, de sua visibilidade como obra do Poder Público municipal. Assim como o Parque da Vila Prudente, a obra localiza-se em área que, em 2003, constituía importante base eleitoral para o então Secretario do Verde e Meio Ambiente, Adriano Diogo.

Diferentemente de parques como Pinheirinho D’Água e Cordeiro não só no tocante ao porte menor - cerca de $10 \mathrm{mil} \mathrm{m}^{2}$ - a reforma desta praça tampouco surgiu a partir de reivindicações de grupos locais, mas sim de uma iniciativa do Poder Público, por interesses também adversos aos dois casos anteriores. Desse modo, a prospecção mais detalhada dos anseios dos usuários com relação a este espaço livre não constituía, inicialmente, uma variável priorizada pelo Poder Público neste projeto.

A interação inicial com a população local ocorreu no ano de 2004, e foi estabelecida por meio de reuniões promovidas pela prefeitura na igreja existente na praça com representantes da comunidade, funcionários municipais, além do arquiteto Raul Pereira, profissional do escritório de paisagismo responsável pelo projeto da área.

O critério de representatividade utilizado pelo Poder Público para convocação da comunidade mostrou-se restrito, pois a maioria daqueles que compareceram às reuniões pertencia a grupos ligados à igreja local. Isso resultava em reuniões cujo produto caracterizava-se por uma visão mais parcial das necessidades da comunidade em relação àquele espaço.

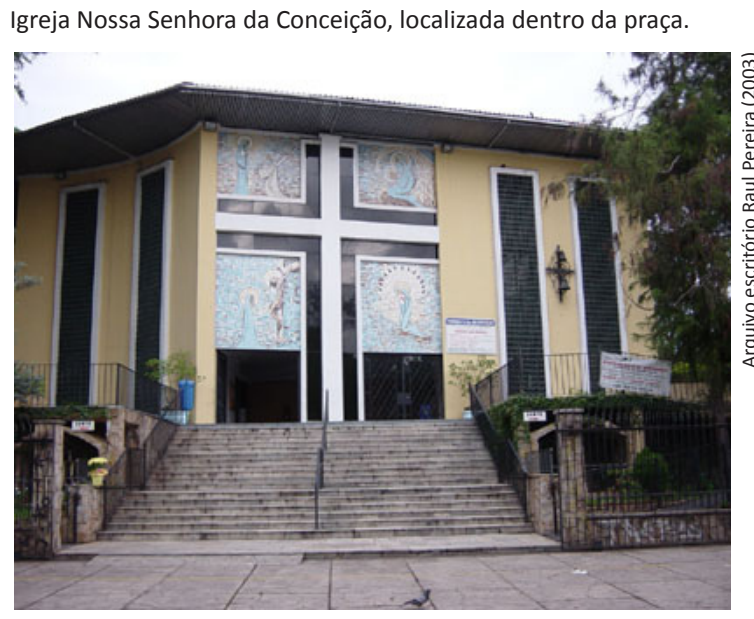


Os relatos dos representantes gravitavam, em grande parte, na questão das perturbações às atividades relacionadas à igreja na praça, tais como a agitação dos diversos grupos de adolescentes que freqüentam o local para os mais diversos fins.

As sugestões propostas sob tal óptica relacionavam-se à restrição da área de piso da praça, visando à redução do número de adolescentes freqüentadores; a colocação de equipamentos urbanos que dificultassem a presença de sem-teto ou mendigos, ou mesmo a não colocação de sanitários públicos da praça, de modo a evitar atividades ilícitas diversas que pudessem ocorrer.

Tais solicitações identificadas nas reuniões públicas foram entendidas como parciais pelo escritório responsável pelo projeto da praça. Embora o prazo para concepção e entrega da primeira proposta estabelecido pela prefeitura fosse bastante reduzido (cerca de um mês), o paisagista responsável pelo escritório considerou a identificação das necessidades de outros grupos que utilizam aquele espaço como prioridade Foi tomada então a iniciativa de promover visitas informais ao local, realizando entrevistas em campo, de modo a sondar outras variáveis de projeto.

O resultado foi a identificação mais aproximada dos outros diversos grupos que utilizam o local, tais como taxistas, proprietários de bancas de frutas e revistas, transeuntes diversos, grupos de idosos que se reúnem para jogar dominó no período da tarde, pessoas que utilizam o banco da praça para sentar e comer seu lanche ou almoço, entre outros.

Merecem destaque também, os variados grupos de adolescentes que utilizam a praça para os mais variados fins, como por exemplo: reuniões de praticantes de capoeira, grupos skatistas, grupos de estudantes das escolas e cursinhos pré-vestibular vizinhos à praça ou até mesmo como significativo ponto para o encontro de casais e amigos virtuais (que se conheceram via internet).

Tendo em mãos essas informações mais abrangentes, foi possível à equipe do escritório conceber um projeto mais sintonizado com as necessidades dos diversos usuários.
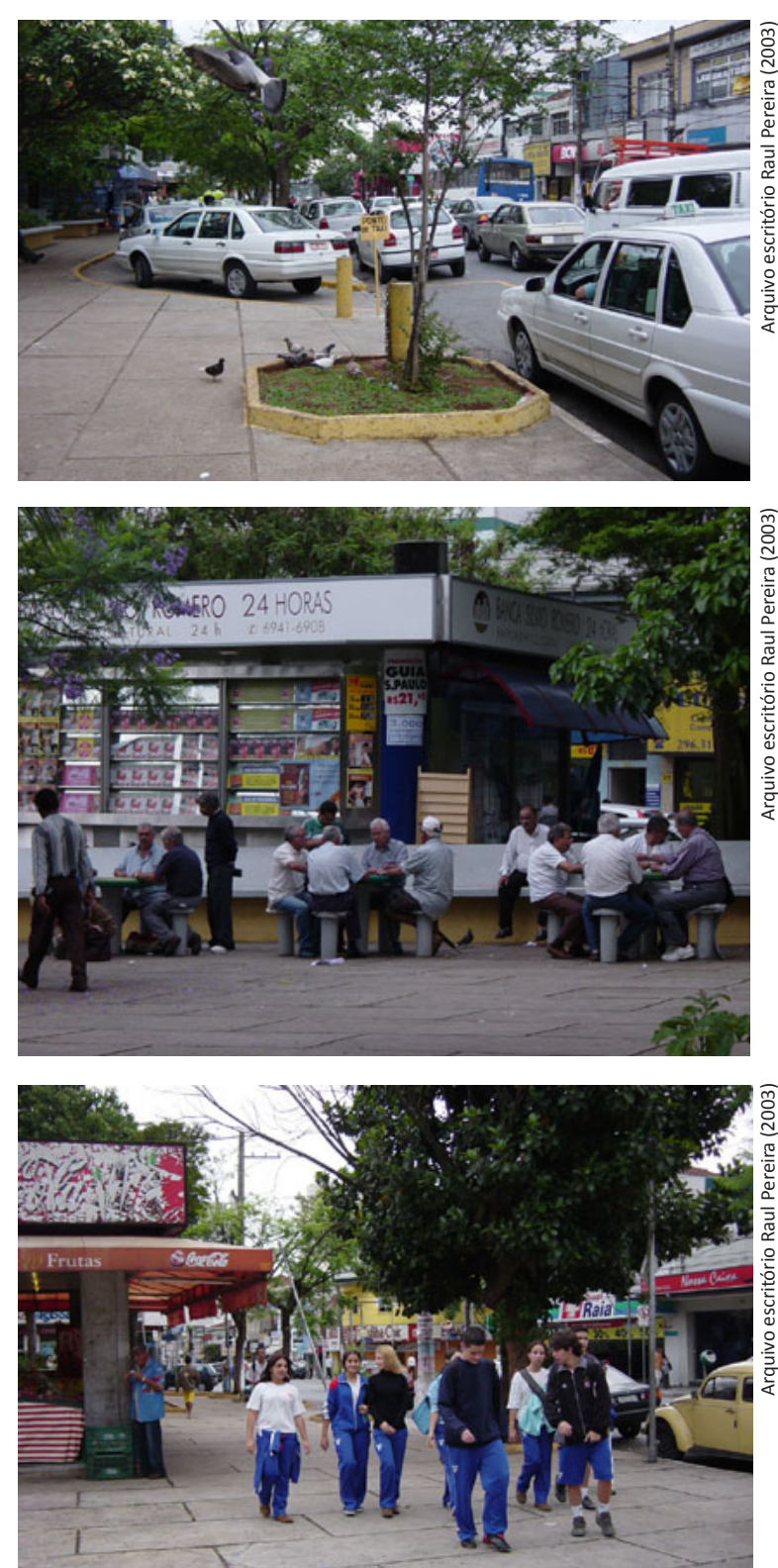

Diferentes usos existentes na praça: ponto de táxi, encontro de estudantes e idosos 
Várias soluções de projeto foram idealizadas a partir desse contato mais próximo (embora breve) com a comunidade local, que envolveu, por vezes, a mediação de conflitos.

Exemplo disso foi a solução de abertura dos sanitários da igreja para uso público, de modo a permitir maior controle para evitar usos inadequados do equipamento, e a utilização de forma mais abrangente pelos usuários do espaço. A área de piso proposta foi ampliada, visando atender aos intensos fluxos de pedestres existentes na praça, e de modo a permitir uso mais flexível do espaço para diversas atividades, como as reuniões de capoeiristas.

Surgiu também a partir da identificação de necessidades, a idéia de criar um acesso específico para carros de noiva nos dias de casamento, resolvendo conflitos de circulação de veículos, existentes sobretudo nos finais de semana.

Apesar de ter suas obras iniciadas com relativa rapidez (ela constituía prioridade da gestão daquele momento), a praça só teve uma pequena parcela executada, limitada à reforma de canteiros e mudança de pisos. Problemas burocráticos relativos aos processos das compensações ambientais que custeariam a praça fizeram com que a obra fosse suspensa e não mais retomada (até o ano de 2008).

Trecho da praça no qual foi executado o
piso previsto no projeto custeado por TCA
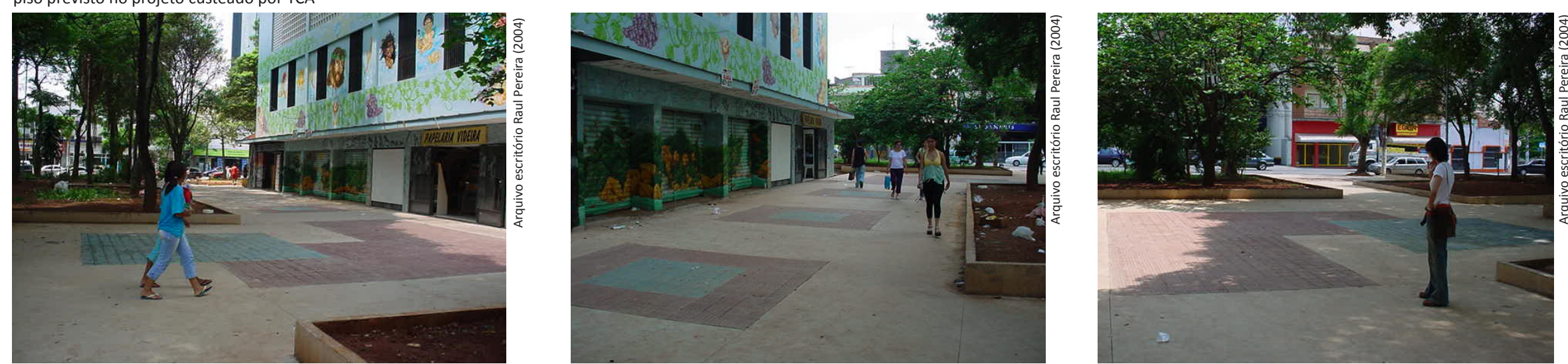
178. Lei Municipal 13.430. Art.106 § 1 - Seção "Elementos estruturais" Subseção "Rede Hídrica Estrutural".

179. Iniciado em março de 2007, o programa da SABESP teve como escopo inicial a despoluição de 42 córregos da cidade de São Paulo. Em fevereiro de 2008, segundo informações divulgadas pelo website do programa (www. corrego limpo.com.br), sete cursos d'água haviam sido despoluídos.

180. Segundo informação fornecida pelo Eng. Agr. Marcio Luiz Monaco da Subprefeitura do Butantã em entrevista realizada para esta pesquisa no dia 01.02.2008, nem todos os parques do programa foram priorizados em um primeiro momento. A ênfase foi dada àqueles que apresentavam quantidade reduzida de obras para a conclusão do processo de tratamento de águas pelo programa da SABESP.

\section{Parques Lineares em São Paulo}

Como parte do Programa de Recuperação Ambiental de Cursos D’Água e Fundos de Vale proposto pelo Plano Diretor Estratégico de 2002 (PDE), a partir de 2006 começa a ser viabilizada a construção de vários parques lineares no Município de São Paulo. Segundo o PDE, o objetivo principal dos novos parques é "recuperar para os cidadãos a consciência do sítio natural em que vivem, ampliando progressivamente as áreas verdes"178.

O plano incide sobre um dos universos mais degradados do município. Quando não estão completamente canalizados e fora do alcance da visão, a maioria dos cursos d'água existentes na cidade encontra-se poluída e ocupada por assentamentos irregulares que agravam ainda mais esse problema devido ao despejo irregular de esgoto e lixo.

O programa, deixado ao encargo da Coordenadoria de Planejamento Ambiental e Ações Descentralizadas da Secretaria do Verde e Meio Ambiente (COPLAN), vem ao encontro da valorização pelo Poder Público (a partir da década de 1990) de medidas para melhoria ambiental, tais como a despoluição e descanalização de cursos d'água (em oposição ao processo ocorrido nas décadas anteriores).

Por estar relacionada à questão dos recursos hídricos, a ação da SVMA recebeu auxílio da Companhia de Saneamento Básico do Estado de São Paulo (SABESP) por meio do Programa Córrego Limpo ${ }^{179}$, que passa a atuar na despoluição dos corpos d'água existentes em alguns dos parques previstos ${ }^{180}$. A parceria entre a SABESP e a prefeitura foi possível em grande parte devido ao fato de ambas as gestões pertencerem à mesma coligação partidária nesse momento (PSDB e DEM), contribuindo para minimizar conflitos burocráticos. A ação permitiu que os benefícios em visibilidade fossem recolhidos pelas duas esferas.

Ao menos dezessete dos parques previstos para o programa utilizam Termos de Compromisso Ambiental (TCA) para viabilizar seu custeio (segundo informações obtidas no ano de 2007). Metade das compensações ambientais relacionadas a esses projetos são originadas por empreendimentos do próprio Poder Público, sobretudo obras viárias e de infra-estrutura urbana.

O programa é a primeira ação sistemática para implantação de espaços livres da Gestão Municipal Serra/Kassab. As últimas ações de porte semelhante a esta haviam ocorrido na Gestão Marta Suplicy (2000-2004), pelo programa Centros de Bairro da EMURB e pela execução da primeira 
remessa de parques viabilizados por compensações ambientais no município.

A localização dos parques lineares previstos pelo programa prioriza as áreas periféricas, distribuindo-os de modo razoavelmente uniforme pelo município.

A implantação de parques lineares, além de contribuir para amenizar o déficit de espaços livres públicos no município, também auxilia na recuperação e posterior preservação dos corpos d'água. Além disso, devido ao caráter linear, tais espaços livres atendem a trechos mais extensos da malha urbana em comparação às ações pontuais.

Embora constitua uma ação louvável do Poder Público, o programa enfrenta diversos problemas de organização que dificultam sua efetiva implantação. A quantidade de parques previstos, por exemplo, se altera a cada nova divulgação do Poder Público entre os anos de 2007 e 2008, variando de um total de vinte a quarenta.

A forma de custeio dos parques também sofreu quantidade semelhante de variações, estando ora vinculada a recursos próprios da SVMA, ora ao Fundo de Desenvolvimento Urbano (FUNDURB) e ora aos TCAs. Tais flutuações se devem em grande parte à fragmentação e suscetibilidade das compensações ambientais paulistanas em relação ao processo de aprovação dos empreendimentos. Essas incertezas dificultam a determinação da fonte de custeio das obras, mesmo que os TCAs sejam responsáveis pelas verbas para a maioria dos parques em qualquer uma das previsões feitas pela prefeitura.

Outro entrave enfrentado pelo programa é a remoção das favelas existentes nas áreas previstas para os novos parques. As dificuldades relacionam-se não só à obtenção de recursos para o devido assentamento das famílias retiradas, como também pelas dificuldades de comunicação entre as diversas repartições públicas necessárias a esse tipo de operação.

Devido aos problemas citados, apenas três dos parques previstos pelo programa encontravamse em obras no ano de 2008: Sapé (Subprefeitura do Butantã), Invernada (Subprefeitura de Santo Amaro) e Parelheiros, sendo este último o único completamente executado ${ }^{181}$. Todos os três foram custeados por compensações ambientais.

Como exemplo dessas ações empreendidas, estudou-se para esta pesquisa o caso específico do Parque do Sapé.

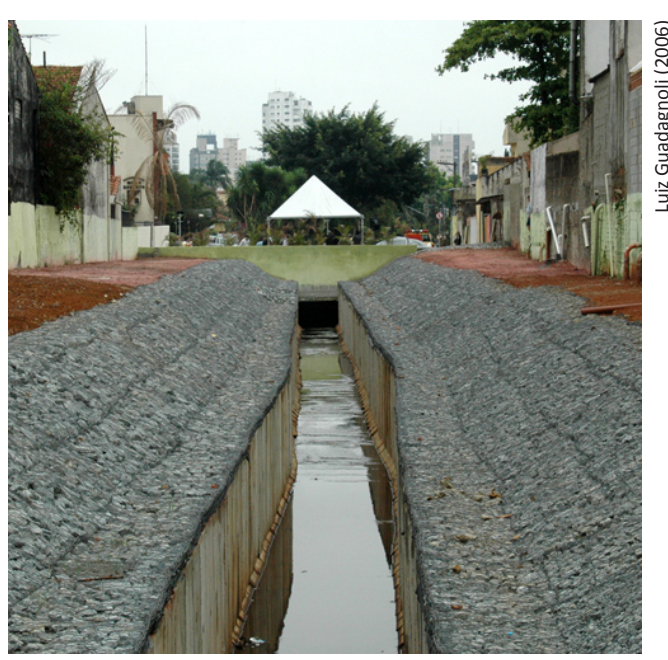

Canalização do Córrego Invernada, parte das obras para construção do parque linear

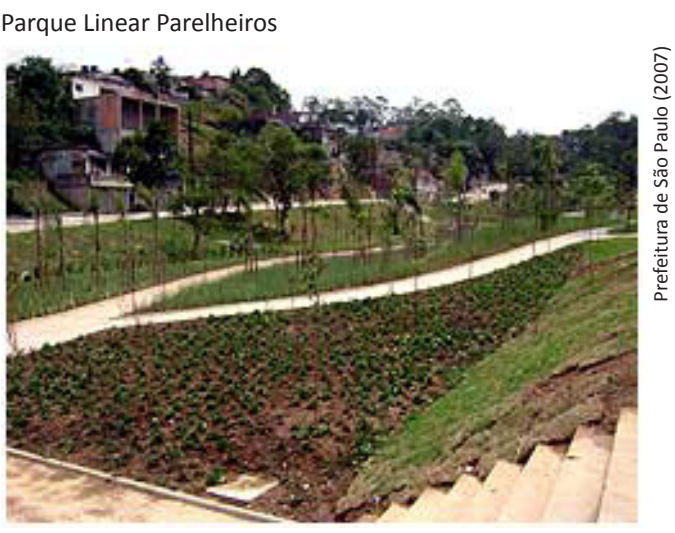

181. Inaugurado em Novembro de 2007 
Tabela 18. Listagem dos parques lineares

previstos para o município de São Paulo em 2008

\begin{tabular}{|c|c|c|c|c|c|}
\hline nome & empreendedor & tipologia & especificação & subprefeitura origem & subprefeitura destino \\
\hline Cabuçu de Cima & privado & residencial & residencial & Vila Maria / Vila Guilherme & Vila Maria / Vila Guilherme \\
\hline Caxingui /Itararé & privado & serviços & hotel & Pinheiros & Butantã \\
\hline \multirow{2}{*}{ Cipoaba } & público & viário & complexo viário & Santo Amaro & \multirow{2}{*}{ São Mateus } \\
\hline & privado & residencial & torre & Santo Amaro & \\
\hline Esmeralda & público & infra estrutura & & Santo Amaro & Butantã \\
\hline Guaratiba & público & viário & avenida & Santo Amaro & Cidade Tiradentes \\
\hline Invernada & público & viário & avenida & Santo Amaro & Santo Amaro \\
\hline Itapaiúna & público & viário & avenida & Santo Amaro & Campo Limpo \\
\hline Jaboticabal & privado & residencial & torre & Santo Amaro & Ipiranga \\
\hline Lajeado & privado & residencial & loteamento & Butantã & Itaquera \\
\hline Mazzei & público & transportes & metrô & Santana/Tucuruvi & Santana/Tucuruvi \\
\hline M'Boi Mirim & privado & residencial & abertura viário & Santo Amaro & M'Boi Mirim \\
\hline Moenda Velha & público & educacional & escola & Campo Limpo & Campo Limpo \\
\hline Mongaguá & privado & educacional & universidade & Mooca & São Miguel \\
\hline Parelheiros & público & transportes & $\begin{array}{l}\text { corredor } \\
\text { de ônibus }\end{array}$ & Parelheiros & Parelheiros \\
\hline Rio Verde & privado & comercial & shopping & Itaquera & Itaquera \\
\hline \multirow{3}{*}{ Sapé } & privado & residencial & $\begin{array}{c}\text { conjunto } \\
\text { habitacional }\end{array}$ & Butantã & \multirow{3}{*}{ Butantã } \\
\hline & & comercial & shopping & Butantã & \\
\hline & privado & espaço livre & parque & Vila Mariana & \\
\hline Taboão & público & infra estrutura & canalização de córrego & Itaquera & Itaquera \\
\hline
\end{tabular}

Fonte: SVMA 2007 


ses

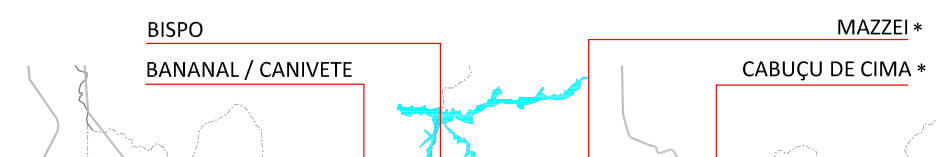

MAZZEI*

Paulo em 2008

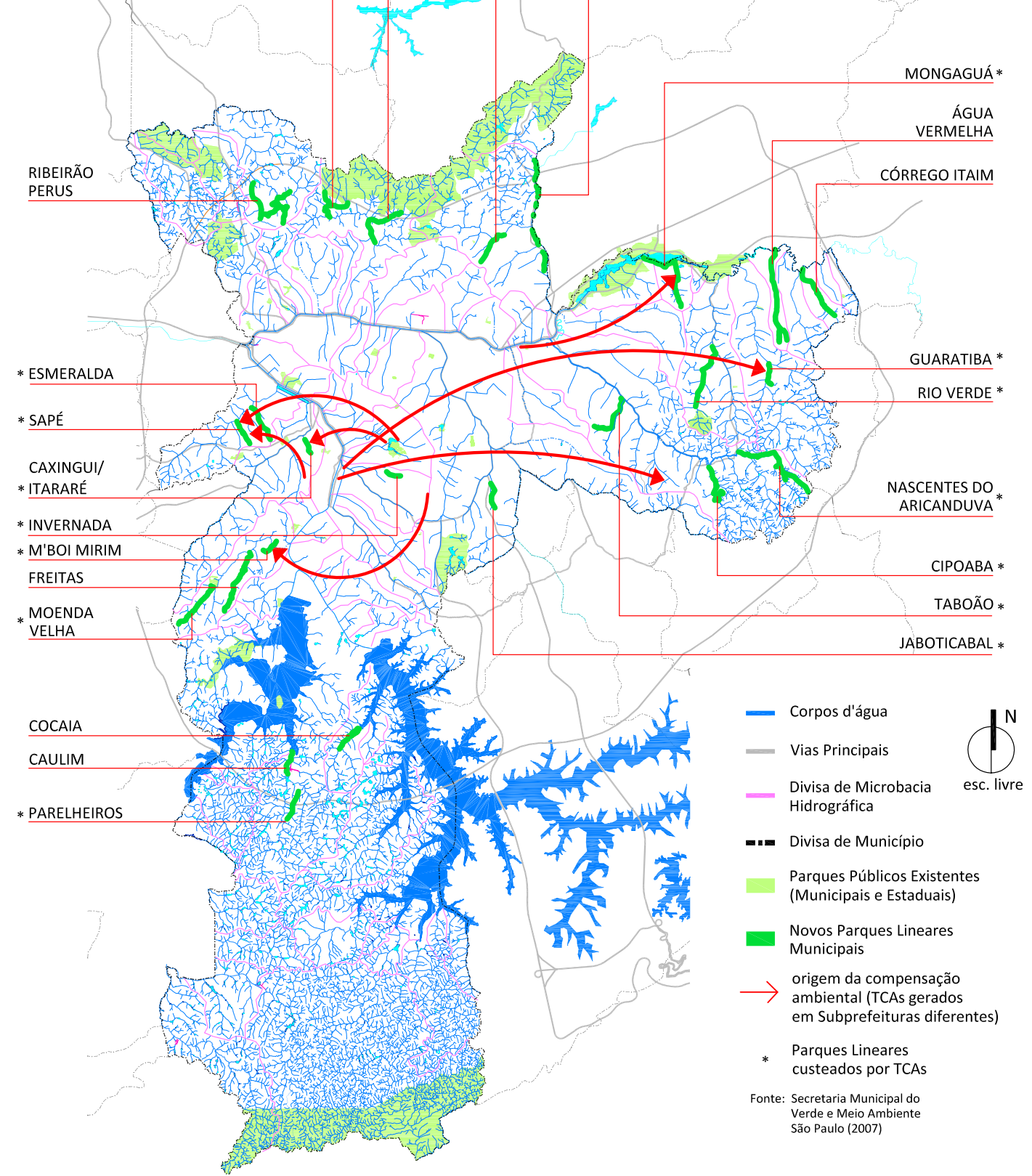




\section{Parque Linear do Sapé}

Localizado no Distrito de Rio Pequeno, o Sapé faz parte dos 40 parques lineares propostos no Plano Regional Estratégico da Subprefeitura do Butantã ${ }^{182}$, zona oeste paulistana.

Assim como ocorre com os outros projetos de parques lineares previstos no Plano Diretor Estratégico do município, a área recebeu o nome do córrego que percorre sua extensão.

O Sapé integra um conjunto de cinco córregos de cursos paralelos que desembocam no Rio Jaguaré (às margens do qual foi implantada a Avenida Escola Politécnica) e cujos montantes situam-se na linha de cumeeira delimitada pela Rodovia Raposo Tavares.

O parque atravessa um entorno residencial horizontalizado de médio e baixo poder aquisitivo. Vários trechos da faixa non aedificandi do córrego encontram-se ocupadas por uma favela consolidada, composta em sua maioria por construções de alvenaria. Também existem diversas construções de madeira diretamente apoiadas no Córrego do Sapé.

O histórico do projeto para um parque ao longo do Córrego do Sapé inicia-se no ano de 2005, quando a construtora Company gera um TCA de 84 árvores para plantio externo ao lote em função de um empreendimento residencial próximo ao Bairro Portal do Morumbi.

Segundo o Eng. Agr. Marcio Luiz da Silva Monaco ${ }^{183}$, a Câmara de Compensação Ambiental da SVMA consultou a Subprefeitura do Butantã sobre possíveis locais para aplicar o TCA. O córrego do Sapé foi o local indicado, pelo fato de fazer parte do Plano Regional Estratégico da Subprefeitura. A área abrangida pelo Plano, no entanto, restringe-se a uma porção próxima à Rodovia Raposo Tavares com cerca de 300m, ainda não invadida pela favela. No entanto, desde o início do processo, o escopo do projeto previsto pela Subprefeitura estende-se até a jusante do córrego (percorrendo um total de quase $2 \mathrm{~km}$ ), inclusive nas áreas de favela, que precisarão ser desocupadas para a viabilização do parque.
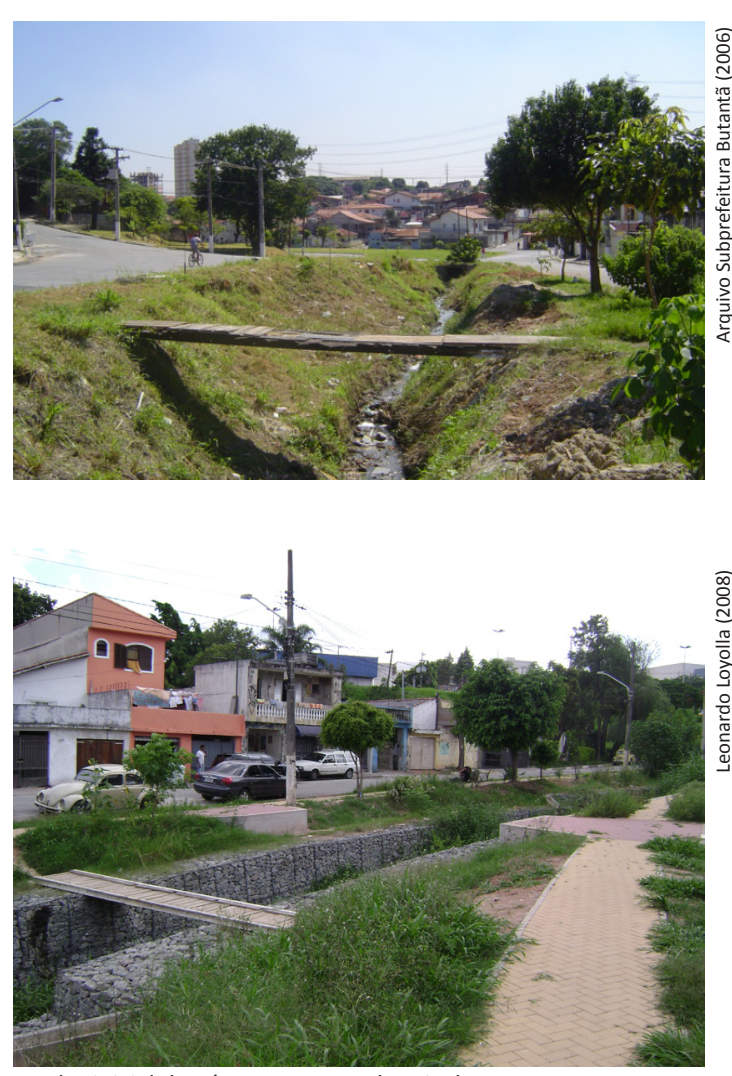

Trecho inicial do córrego antes e depois do serviço de contenção das margens

182. Livro $\mathrm{X}$, anexo à Lei Municipal 13.885 , de 25 de agosto de 2004.

183. Dados fornecidos em entrevista realizada com o Eng. Agrônomo da Subprefeitura do Butantã no dia 01/02/2008. 


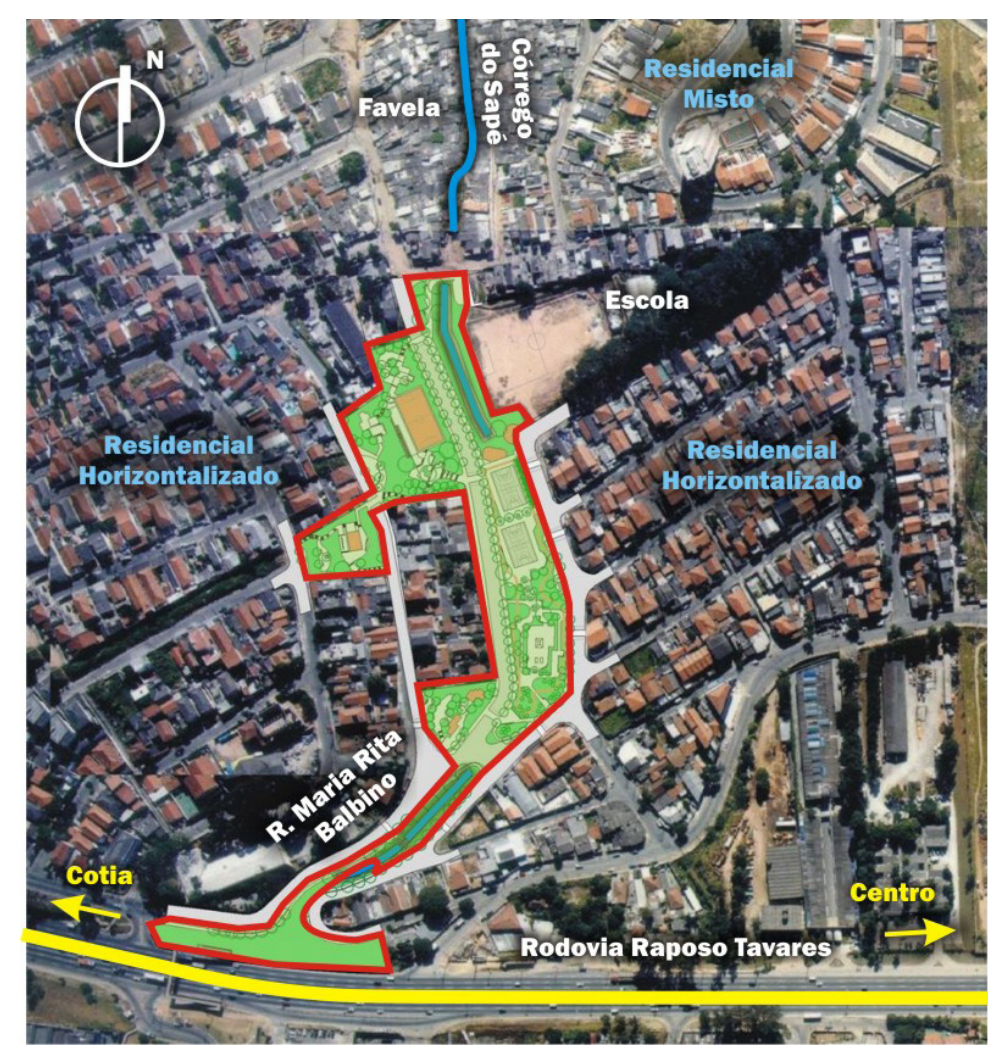

Vista geral do entorno do parque. Área horizontalizada

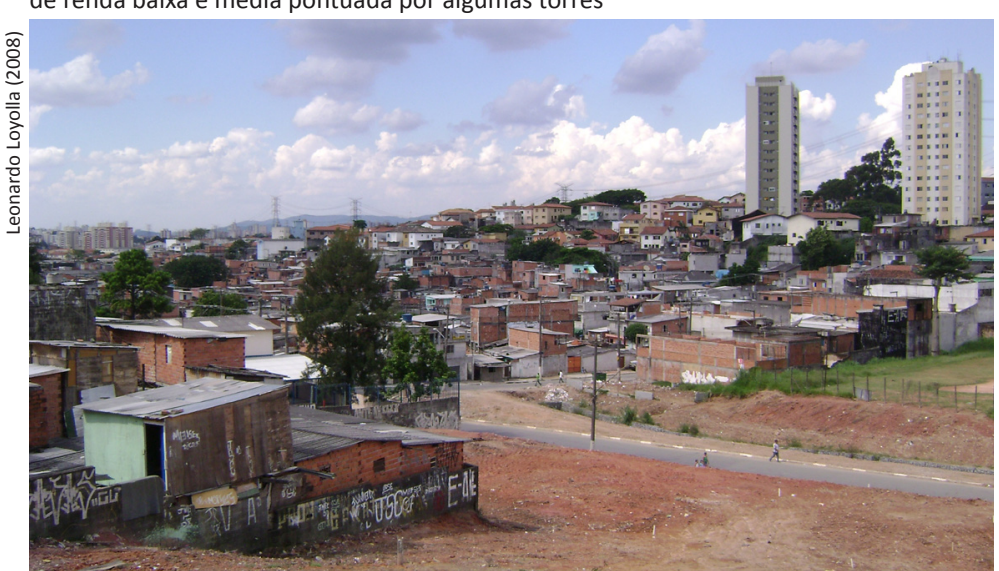

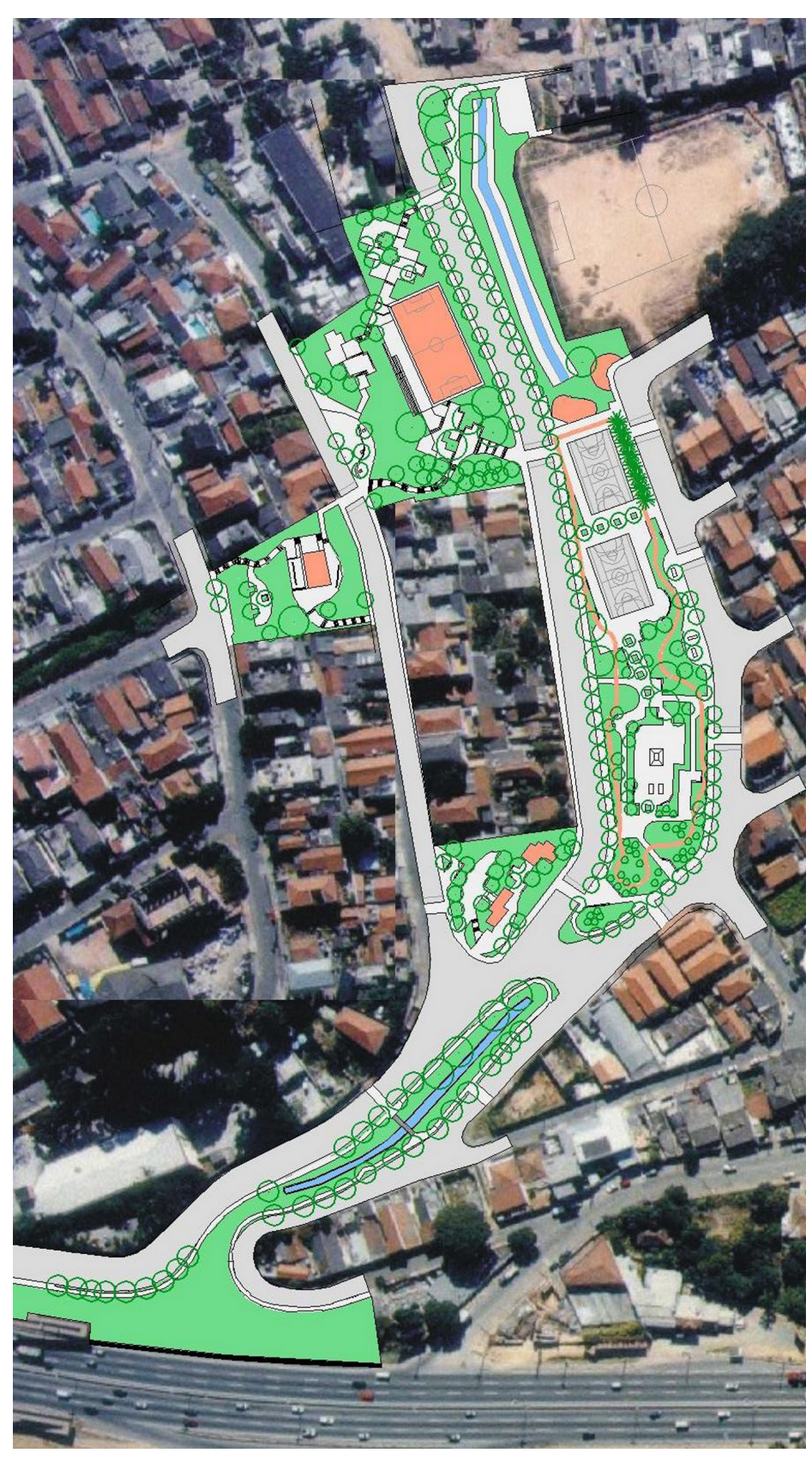

Cap. III Compensações ambientais em São Paulo 147 

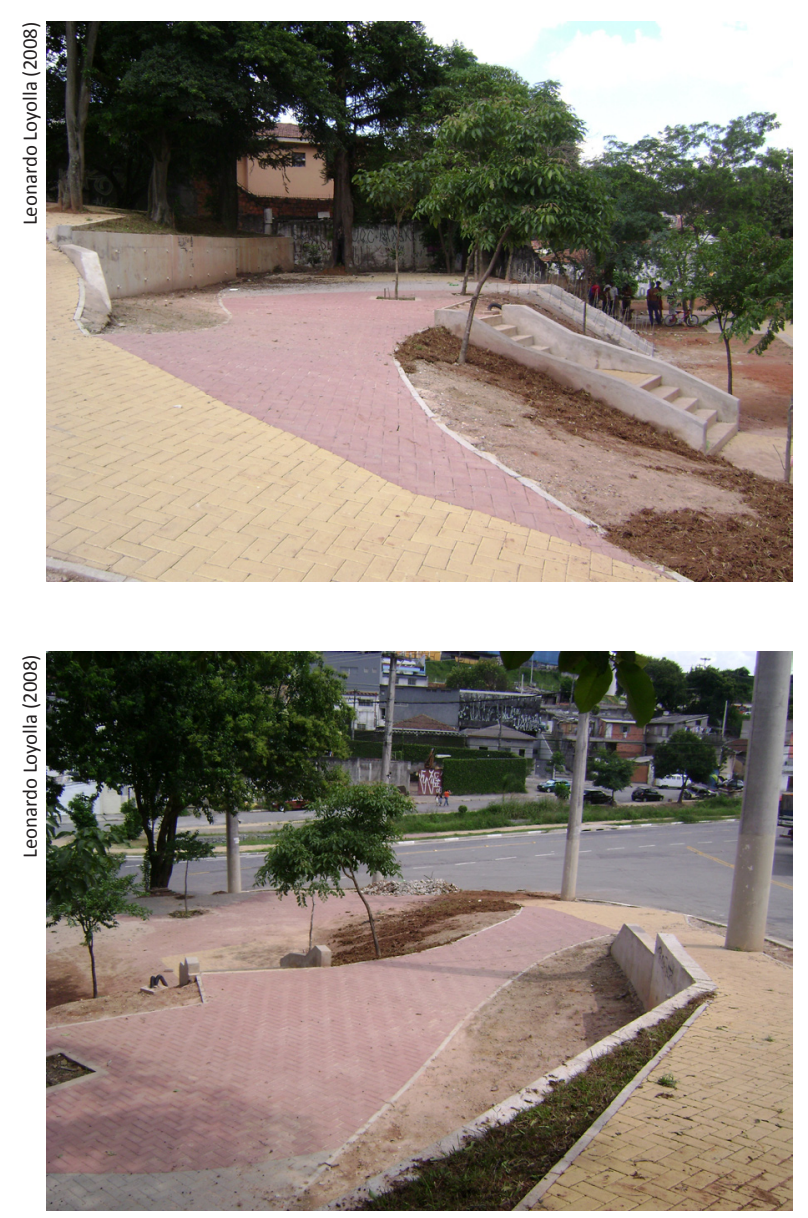

Obras de uma das praças que compõem o parque, na Rua Siguenori Tateishi. Grande desnível vencido por muros de arrimo e escadas.
Antes de iniciar o projeto, foi realizada uma consulta pública às lideranças de bairro. Apenas seis pessoas compareceram. Monaco afirma que os debates praticamente só gravitaram em torno de reivindicações como retirada de lixo e ratos do local e um possível tamponamento do córrego. Uma única proposição projetual foi feita pela população, solicitando a construção de um espaço específico para realização de cultos ao ar livre para uma igreja do entorno. Naturalmente, devido ao seu caráter excessivamente restritivo, tal proposta não foi aceita. A partir desse momento, o Poder Público atuou de forma autônoma em suas proposições.

Monaco considera que o Poder Público deveria ter insistido nas consultas públicas, pois tal processo auxiliaria na apropriação do espaço pela população local, que passaria a cooperar para a manutenção e fiscalização da área.

O projeto paisagístico foi direcionado pela empresa Company ao escritório Solo Ambiente, que possuía experiência na área de planejamento ambiental, embora tivesse realizado poucos projetos paisagísticos anteriormente ${ }^{184}$.

Foram realizadas 25 reuniões entre o escritório contratado, o DEPAVE e a COPLAN. A equipe da Subprefeitura do Butantã participou dessas reuniões, mas segundo Monaco, foram dadas poucas oportunidades para opinar ou intervir no projeto.

Seguindo as diretrizes iniciais, o projeto previu a implantação em três fases. A primeira delas envolveria a contenção das margens do trecho do córrego não invadido pela favela. A segunda, a implantação de praças com equipamentos em três pontos da área próxima à favela. E a última etapa envolveria a retirada da favela e a implantação de equipamentos no restante do parque.

O custeio das duas primeiras fases seria feito por compensações ambientais. A fase final ficaria ao encargo do Poder Público, sendo a mais dispendiosa e complicada devido à necessidade de retirada da favela existente. 
Os recursos gerados pelo TCA da empresa Company eram, segundo cálculos realizados pela SVMA, suficientes para custear o projeto paisagístico do parque e a execução de contenções à beira do córrego. $\mathrm{O}$ projeto previu o uso da técnica de gabião para conter as margens.

O empreendedor optou por doar o projeto paisagístico e custear apenas a realização das obras de contenção. Conseqüentemente, tais obras saíram a um preço mais elevado que o proposto inicialmente, embora o valor global do TCA permanecesse o mesmo.

Durante o ano de 2006 as obras tiveram um andamento lento, sendo efetivadas em 2007, quando foram entregues os gabiões. Em fevereiro de 2008, a segunda fase da obra estava em andamento, com a execução do piso das praças previstas no projeto. 


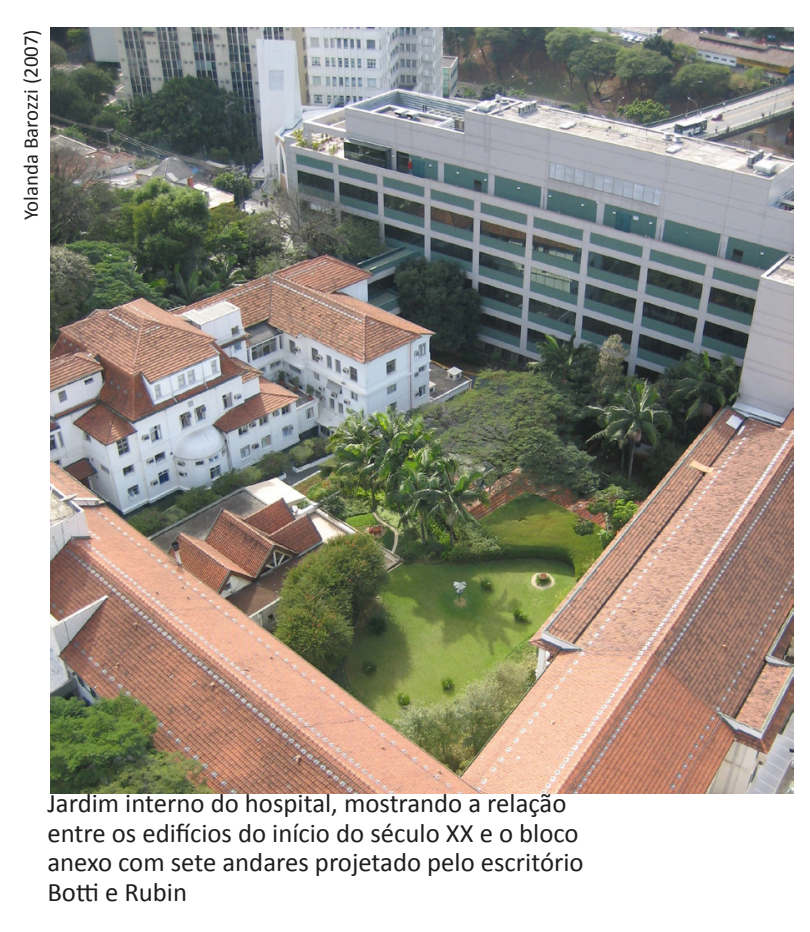

185. Todas as citações referentes à arquiteta neste trabalho baseiam-se em entrevista realizada no dia 04.03.2007

\section{Hospital Alemão Oswaldo Cruz}

Situado no distrito de Bela Vista (Subprefeitura da Sé), o Hospital Alemão Oswaldo Cruz localiza-se na confluência da Rua Treze de Maio - que delimita o início da Av. Paulista - com a Rua João Julião - que atravessa o vale do córrego do Itororó, sobre o qual atualmente existe a Avenida 23 de Maio. Seu terreno, com $23.500 \mathrm{~m}^{2}$, localiza-se em um dos pontos mais altos do espigão da Av. Paulista e antigamente era ocupado pela residência pertencente a Euthébio Prado. A área foi comprada em 1905 pela sociedade do do Hospital Oswaldo Cruz, formada por imigrantes alemães, suíços e austríacos em 1863.

Devido a dificuldades para angariar fundos, a construção da obra só seria concluída no ano de 1923. Um novo pavilhão seria construído em 1931. O terreno original possuía diversas árvores de grande porte, tais como fícus, paineiras, jatobás, jaqueiras, mangueiras, abacateiros, figueira e vários eucaliptos. Essa arborização foi mantida até os dias atuais em sua maioria e se tornou um dos principais diferenciais das instalações da instituição. Essa mesma vegetação iria contribuir para problemas futuros, visto que seu porte conflitava com as demandas por crescimento das próprias instalações do hospital e com o adensamento urbano da região. Em 2007, entorno do hospital - assim como a região da Av. Paulista - é bastante verticalizado e composto por edificações de usos variados, sobretudo comerciais, residenciais e de serviço.

No ano de 1996 começariam obras para ampliação das instalações do hospital. Inicialmente foi concebida uma nova edificação para abrigar o estacionamento, que tradicionalmente ocupava um bosque de eucaliptos voltado para a Rua Treze de Maio, e não conseguia mais dar conta dos sucessivos aumentos na demanda. O projeto, a cargo do escritório Botti Rubin Arquitetos, previa garagem subterrânea com três subsolos. A construção dessa nova garagem envolveria a retirada de várias árvores, obrigando a sua respectiva compensação.

O projeto paisagístico foi direcionado ao escritório da arquiteta paisagista Miranda Martinelli Magnoli ${ }^{185}$, que já trabalhara com os arquitetos da Botti Rubin em outros projetos, como o Shopping Pátio Higienópolis. A equipe de Magnoli realizou um estudo 
inicial detalhado, no qual identificava a importância de diversas espécies existentes no local, principalmente em função de seus grandes portes.

Nessa época, a compensação ambiental sequer estava regulamentada oficialmente, mas os procedimentos para sua realização começavam a ser delineados pelo Poder Público. O relatório realizado pela equipe de Magnoli apresentava um grau de detalhamento superior àquele encontrado nessa época, e contribuía para gerar subsídios da futura padronização de procedimentos.

Com base no diagnóstico realizado, Magnoli buscou esclarecer os arquitetos sobre a importância da realização da obra com o mínimo possível de interferências na vegetação existente no terreno. Atendendo a esse princípio, propôs-se o desenho da garagem ocupando o bosque de eucaliptos, espécies exóticas às quais foi atribuído valor inferior às árvores restantes.

O projeto envolveu, ao todo, a remoção de 44 exemplares, dividido em 31 cortes e 13 transplantes autorizados pelo DEPAVE. A maioria dos transplantes foi realizada em canteiros da Av. 23 de Maio. Segundo Magnoli, o local indicado para o transplante era inadequado para receber árvores que viveram durante dezenas de anos em situação bastante diferente, o que comprometeria sua possibilidade de sobrevivência.

As medidas autorizadas exigiram como compensação o plantio de 310 mudas, das quais foi possível a colocação de apenas 76 no próprio terreno. $\mathrm{O}$ restante das mudas previstas foi relocado em parte para o plantio no entorno do hospital e parte em doação de mudas ao viveiro municipal. 262 mudas foram plantadas no entorno do terreno, em ruas do bairro da Bela Vista. Esse plantio, realizado no final do ano de 2001, teve prazo de manutenção estipulado para até janeiro de 2004.

A doação envolveu uma quantia de 620 mudas doadas ao Viveiro Municipal Manequinho Lopes, com 310 protetores. Como se pode observar, essa quantia constitui o dobro do previsto inicialmente (310), devido ao fato de constituírem compensação externa ao local que gerou o dano ambiental.
Jardim sobre laje do estacionamento construído na reforma de 1996 a 2004. À esquerda, portaria de acesso à Rua Treze de Maio

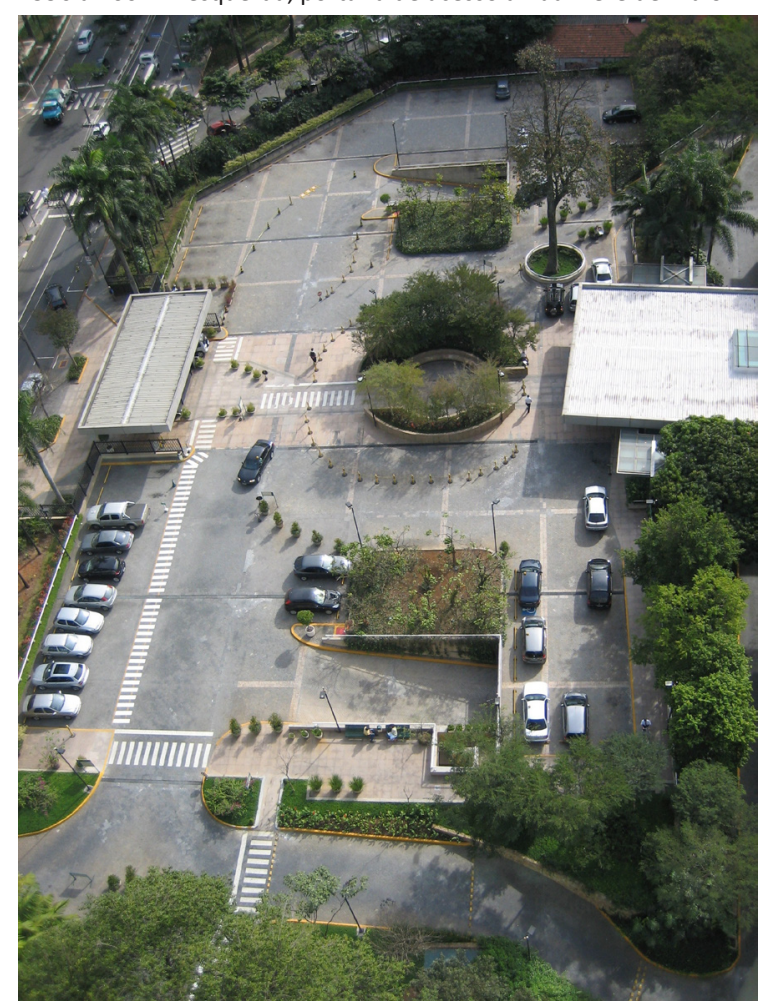




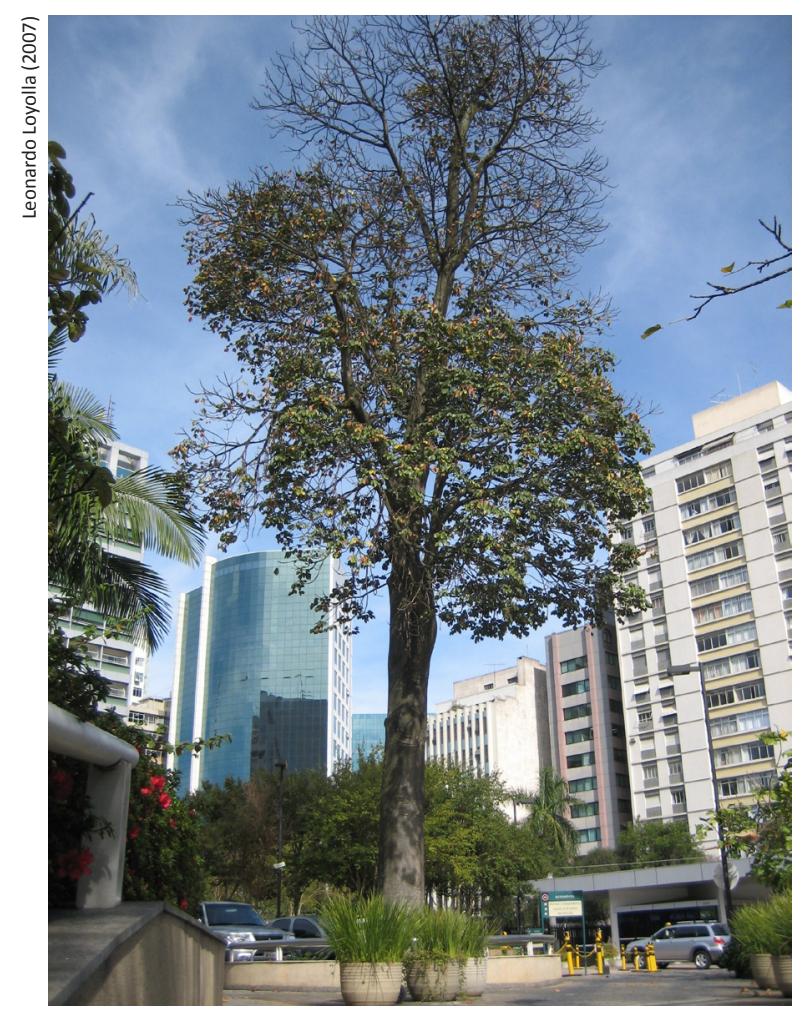

Porte esbelto e imponente do exemplar de Chichá existente no estacionamento do hospital.
Dentre as árvores mantidas no terreno, encontrava-se o chichá (Sterculia chicha), que ocupava posição central na projeção do novo estacionamento. Para que fosse possível manter essa árvore, foi proposta a construção de um tubulão de concreto que envolvesse suas raízes (com um diâmetro superior a $10 \mathrm{~m}$ ) e atravessasse os três novos subsolos da garagem. A medida seria bastante dispendiosa e pouco usual se comparada ao que havia sido feito no município até então.

Esse foi o primeiro de vários trabalhos de negociação e conscientização realizados por Miranda, tanto em relação aos empreendedores quanto aos próprios arquitetos da obra. Nesse sentido, a imagem de prestação de serviços de qualidade que sempre cercou o hospital desempenhou papel importante. A direção do hospital apropriou-se da idéia de realizar obra com preocupações acima da média como forma de contribuir para a boa imagem que já detinha.

Isso levou os responsáveis a autorizar a construção do tubulão em volta do chichá, um dos diversos cuidados que seriam tomados com a execução do projeto paisagístico ao longo da obra. Além da construção do tubulão, foi necessária a realização de podas localizadas nessa árvore, de modo a contrabalançar para que suportasse a maior exposição aos ventos que a retirada dos eucaliptos vizinhos provocou. Também foi realizado o atirantamento da árvore, de modo a evitar seu desequilíbrio em função da retirada de terra para execução da obra.

A execução dos serviços paisagísticos ficou a cargo da empresa Bomjardim, que já havia realizado diversas parcerias com Magnoli e cuja experiência auxiliou na realização de trabalhos com exigências de qualidade acima da média. Seu proprietário, o viveirista de origem germânica Walter Doering, possuía fluência nas negociações com a instituição, o que facilitou o andamento da obra.

O início das obras para um novo edifício de internação em 2001, um bloco laminar de 10 andares paralelo à Rua Santa Ernestina, trouxe à tona novas preocupações com a vegetação existente no terreno. 
Um exemplar de figueira (Ficus macrophylla), com cerca de $25 \mathrm{~m}$ de altura e DAP de 2,20m, localizava-se próximo à área prevista para a nova construção e colocou em pauta a discussão sobre sua retirada. Contrariando a postura dos arquitetos, a paisagista buscou soluções que mantivessem o fícus existente. Foram necessárias longas negociações com o arquiteto e os empreendedores até que fosse proposta uma solução arquitetônica que contemplasse a preservação da árvore. Novamente a alternativa envolveu obras dispendiosas: a lâmina de dez andares projetada teve de abrigar um recorte em sua fachada frontal com altura dos cinco pavimentos iniciais e uma profundidade de $2,50 \mathrm{~m}$, de modo a acomodar a projeção da copa da árvore existente.

Outro cuidado excepcional da obra envolveu três exemplares de paineiras (Chorisia speciosa) localizados próximos ao muro da Rua Maestro Cardim. Embora não estivessem na área de escopo do projeto arquitetônico, as árvores apresentavam estado fitossanitário ruim, o que exigiu análise sobre a necessidade de suas compensações junto à prefeitura. Apesar de ter solicitado a vistoria das paineiras, o DEPAVE não possuía equipamentos para a análise adequada do seu risco de queda. Negociações com a equipe do hospital resultaram na aquisição de um aparelho específico importado da Alemanha (Resistograph) para realização dos testes necessários com as árvores. A partir de então, o equipamento passou a ser emprestado à equipe da prefeitura para avaliação de outros casos complexos. Com base nos resultados do teste foi autorizado o corte das três árvores. Mesmo com a liberação do DEPAVE, a paisagista preferiu retirar apenas uma delas, sendo que os outros dois exemplares foram mantidos sob estado constante de monitoramento.

A atenção dada à obra do hospital consumiu uma parcela considerável do tempo da paisagista, visto que o processo se estendeu por quase dez anos (até o ano de 2004). O longo tempo de realização da obra fez com que o projeto acompanhasse a evolução dos mecanismos de compensação ambiental durante esse período. $O$ padrão de qualidade superior dos serviços prestados permitiu, inclusive, que a obra auxiliasse no estabelecimento de novos critérios incorporados posteriormente ao corpo da legislação, atuando com um caráter propositivo.

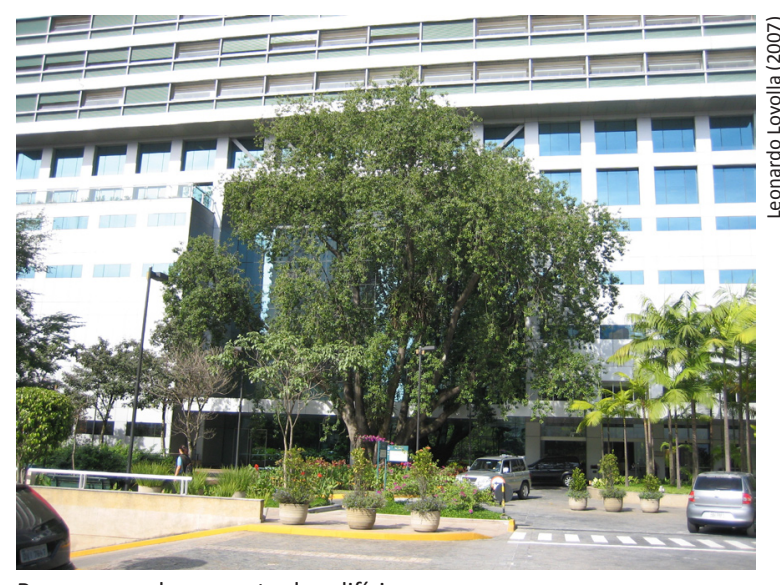

Recuo no embasamento do edifício anexo para acomodação do ficus existente no terreno original 


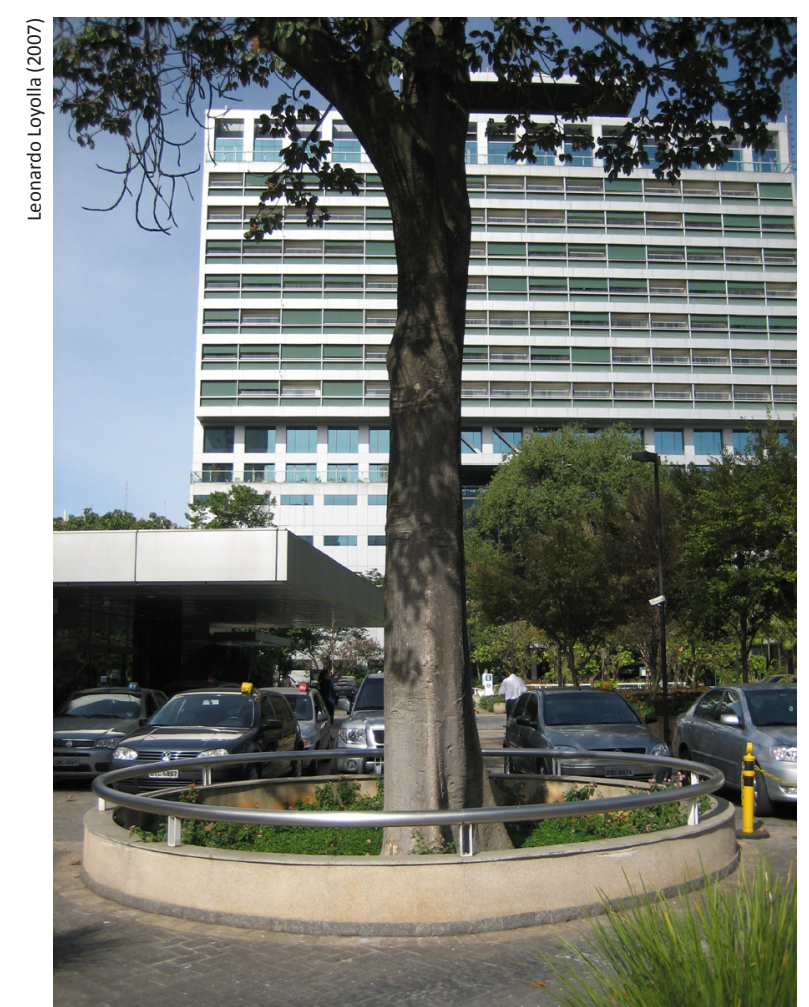

Desenho do canteiro evidencia o diâmetro

do tubulão construído para preservar o

exemplar de Chicá existente no terreno
Pode-se exemplificar essa contribuição por meio do caso de uma contrapartida realizada nas obras de acesso ao hospital pela Rua 13 de Maio. Ao surgirem necessidades de contrapartida a obras realizadas, foi proposta a concessão de uma faixa com $1 \mathrm{~m}$ de largura e 120 m de comprimento para o Poder Público, possibilitando a ampliação da calçada. Embora não ocorra nos mesmos moldes da situação descrita, a doação de áreas para o Poder Público como forma de compensação seria incorporada como legislação por meio da Portaria DEPAVE 122/2001.

Foi igualmente inovador o acompanhamento dado ao plantio compensatório realizado no entorno da obra. Trabalhou-se com um prazo de 30 meses para manutenção das mudas plantadas, enquanto o usual eram no máximo 24. Além disso, foi realizado um trabalho de conscientização a respeito das árvores plantadas, com o fornecimento de panfletos explicativos à população envolvida. Essa postura só seria incorporada posteriormente à legislação, com a criação da possibilidade de pagamento parcial das compensações por meio de projetos de educação ambiental ${ }^{186}$. 
187. Essa região, no entanto, receberia nesse período o projeto do Parque do Gato, de autoria do arquiteto-paisagista Raul Pereira.

188. Cf. "Mapeamento das Ações".

\section{Considerações Gerais}

Analisando a localização dos espaços livres gerados por compensações ambientais, percebese que eles distribuem-se de forma razoavelmente homogênea pelas diferentes regiões do município. Durante a gestão Marta Suplicy (2000 e 2004) - período no qual foram iniciados quase todos os projetos públicos aqui analisados - todas as regiões da cidade (zonas leste, oeste, norte e sul) receberam no mínimo um espaço livre público custeado por TCAs, com exceção da área centra1 ${ }^{187}$.

O uso residencial foi a tipologia que originou a maior parte das compensações ambientais para custeio de espaços livres públicos paulistanos. Essa proporção se repete para os casos envolvendo outras modalidades compensatórias. ${ }^{188} \mathrm{O}$ local de origem das compensações, no entanto, nem sempre corresponde ao entorno imediato do espaço livre custeado. Especificamente com relação aos parques e praças, observa-se que metade dos casos (Parque Pinheirinho D’água, Praça Silvio Romero, Parque do Cordeiro e Parque Vila Prudente) foram financiados por compensações ambientais provenientes de outros bairros. Com exceção do Parque da Vila Prudente, cujas compensações vieram da zona leste, todos os outros casos tiveram origem na região sudoeste da cidade.

Com relação à faixa de renda média das regiões que receberam os espaços livres, percebe-se novamente um equilíbrio: o Parque do Cordeiro e as praças Nandina Haddad e Anna dos Santos Figueiredo localizam-se em áreas da cidade com maior poder aquisitivo. O restante dos projetos - Parque Pinheirinho D’água, Praça Silvio Romero, Parque Jacintho Alberto, Parque da Vila Prudente e Parque Linear do Sapé - localizam-se em áreas periféricas, com poder aquisitivo médio ou baixo.

Considerando-se que as maiores demandas por espaços livres públicos do município encontram-se em suas áreas periféricas, esperava-se que as ações da prefeitura se concentrassem nesses lugares. $\mathrm{O}$ critério para implantação das áreas, no entanto, não correspondeu necessariamente às demandas da cidade. Algumas vezes esteve relacionado a interesses políticos. É o caso da Praça Silvio Romero e do Parque Vila Prudente, ambos na região leste do município, área de influência política de Adriano Diogo, Secretário Municipal do Meio Ambiente na época de início desses projetos. 
Outra constatação pertinente é o fato da maioria dos parques custeados por compensações ambientais em São Paulo até o ano de 2008 ter sido produzida pelo escritório do arquiteto Raul Pereira. Raul trabalhou durante a década de 1980 na Prefeitura do Município de Osasco, coordenando projetos participativos de arborização urbana (Mutirão Verde) e urbanização (Projeto Mutirão). Também coordenou o projeto de educação ambiental "Uma fruta no quintal” no município de Diadema. Esse é um dos motivos pelos quais todos os projetos realizados por Raul contaram com a participação mais ativa das comunidades locais em seus processos de viabilização, embora esse tipo (bem-vindo) de atuação não fosse prevista inicialmente pelos órgãos públicos ${ }^{189}$.

Além disso, as experiências anteriores bem sucedidas de Raul ocorreram em cidades com gestões do Partido dos Trabalhadores, linha ideológica com a qual o profissional já mantinha sólidos vínculos. A aceleração das obras de espaços livres públicos paulistanos custeados por compensações ocorreram na gestão Marta Suplicy, do Partido dos Trabalhadores. Podese perceber, desse modo, que a predominância de projetos direcionados à equipe de Raul deve-se tanto à sua reconhecida experiência na área, quanto a um contexto politicamente favorável à sua atuação.

A afinidade partidária, no entanto, não foi motivo suficiente para garantir fluência no processo de viabilização dos projetos. A desorganização das equipes responsáveis pela aprovação dos projetos tornou o processo lento e tortuoso. Tal dificuldade pode ser exemplificada pelo caso do Parque Pinheirinho D'água, no qual alguns setores foram executados ao mesmo tempo em que outras áreas ainda aguardavam aprovação pelos órgãos públicos. A Arqta ${ }^{a}$ Daniela Ramalho - que participou da equipe do Arq. Raul Pereira na época de aprovação do Parque Pinheirinho D’Água - relata que a falta de sintonia entre alguns técnicos do DEPAVE e a realidade das obras chegava ao ponto de se exigir minúcias no detalhamento de áreas que não estavam mais disponíveis para projeto, devido a problemas na execução. Era o caso da área 4 do parque, sobre a qual foi construída a EMEF Rogê Ferreira. Mesmo durante a execução da edificação, os técnicos da prefeitura discutiam o detalhamento da quadra antes prevista para o local ${ }^{190}$.
189. Cf. PEREIRA, Raul Isidoro. O sentido da paisagem e a paisagem consentida. Tese de Doutorado. São Paulo, FAUUSP, 2006.

190. Informações fornecidas em entrevista realizada em 27.10.2005 
A obtenção fragmentada de recursos para execução foi outra característica comum a todos os projetos aqui analisados. Por esse motivo, as obras de menor porte - Praça Anna dos Santos Figueiredo $\left(4.000 \mathrm{~m}^{2}\right)$ e Nandina Haddad $\left(5.600 \mathrm{~m}^{2}\right)$ foram completamente executadas com verbas provenientes de compensações ambientais antes dos parques analisados. O projeto da Praça Silvio Romero teve apenas uma pequena parte executada e foi definitivamente suspenso.

Com exceção do Parque Linear do Sapé, iniciativa mais recente que se vincula a um programa distinto, os demais projetos foram parcialmente executados e permaneceram desse modo por vários anos. Todos possuem maior porte, com mais de $30.000 \mathrm{~m}^{2}$. Os parques do Cordeiro e Jacintho Alberto tiveram suas obras retomadas no ano de 2006 e foram finalizados respectivamente em 2007 e 2008, com verbas orçamentárias próprias da SVMA, ao invés de TCAs. 


\section{CAPÍTULO IV}

Avanços e Retrocessos 



\section{o que falta aperfeiçoar...}

\section{0 fôlego real das compensações ambientais}

Os benefícios para a cidade propiciados pela compensação ambiental são vistos com cautela por alguns profissionais envolvidos com o mecanismo. A arq. Célia Seri Kawai ${ }^{191}$, diretora do DEPAVE nos anos de 2006 e 2007, considera que o poder de influência das compensações no custeio de novos espaços livres no município é muito pequeno face ao tempo exigido pelos trâmites burocráticos e à fragmentação dos recursos gerados. De fato, todos esses problemas dificultam o funcionamento do mecanismo e serão analisados mais à frente. Mas a questão principal reside em descobrir se esses entraves são suficientes para reduzir sua significância.

Para Kawai, as compensações ambientais não têm fôlego financeiro para sair do papel de coadjuvantes no custeio de espaços livres públicos no município. Segundo ela, no ano de 2007 o DEPAVE contava com verba suficiente para custear novos espaços livres. Essa situação é no mínimo bastante recente. Matéria publicada no jornal Folha de São Paulo afirma que, durante a Gestão Marta Suplicy a falta de recursos para construção de novos espaços livres era crônica:

O ex-secretário municipal do Verde e do Meio Ambiente Adriano Diogo (PT) diz que em sua gestão também havia poucos recursos. "Sem recursos próprios, utilizamos dinheiro das chamadas compensações ambientais (recursos de empresas cujos empreendimentos causaram danos ao ambiente). ${ }^{192}$

Sob essa lógica, as compensações eram ferramentas provisórias para obtenção de verbas e deveriam ser substituídas por investimentos diretos em novos espaços livres tão logo fosse possível.

Geluda e Young, ao estudarem casos de compensações ambientais como ferramenta de custeio para unidades de conservação de âmbito nacional, endossam esse ponto de vista:
191. Todas as informações citadas neste trabalho referem-se à entrevista realizada com a arquiteta em 15.03.2007

192. BALAZINA, Afra. Cidade ainda tem 7 parques inacabados. Folha de São Paulo, Caderno Cotidiano. 19 de novembro de 2005 
193. GELUDA, L. ; YOUNG, C. E. F. . Financiando o Éden: Potencial econômico e limitações da compensação ambiental prevista na In: IV Constema Nacional de Unidades de Conservação da Natureza. In: Iv Congresso Brasileiro de Unidades de Conservação, 2004 Curitiba. IV Congresso Brasileiro de Unidades de Conservação.

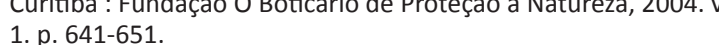

194. RIBEIRO, Mônica. Para combater enchentes, cidade vai ganhar 11 parques lineares. Diário Oficial da Cidade de São Paulo. 15 de fevereiro de 2007.

195. BALAZINA, Afra. Cidade ainda tem 7 parques inacabados Folha de São Paulo. Caderno Cotidiano. 19 novembro 2005.
[...] as unidades de conservação não devem depender de recursos oriundos da degradação para sobreviverem e se ampliarem. Elas devem ter uma verba independente, capaz de sustentá-las e até ampliar sua quantidade, dando à compensação um papel de aliada nesse sentido. Ou seja, não se deve esperar que haja mais danos à natureza para poder tornar eficiente a conservação da mesma, e não se pode aceitar a compensação ambiental como instrumento ordinário de arrecadação fiscal. ${ }^{193}$

De fato, as compensações ambientais não podem ser encaradas como recurso orçamentário. Caso sejam utilizadas em larga escala, podem até se tornar justificativa para a degradação ambiental. Mas mediante os problemas de carência de espaços livres no município, as compensações têm sido importantes aliadas das quais o Poder Público não pôde abrir mão.

Apesar de alguns técnicos da SVMA e DEPAVE não acreditarem no potencial das compensações como fonte de custeio de novos espaços livres, uma parte considerável dos parques lineares previstos para o município a partir do ano de 2007 seriam custeados por TCAs $^{194}$

\section{Fragmentação de recursos e entraves}

Embora não esteja delineada claramente a capacidade de custeio das compensações, os entraves para obtenção de recursos com esse mecanismo são realidade. Por abarcar uma gama de casos com características bastante contrastantes - que vão desde uma árvore em uma casa até centenas de árvores em um condomínio - as compensações apresentam capacidades variadas para captação de recursos. Essa incerteza quanto ao montante gerado pode causar problemas.

Os parques custeados desde 2003 por compensações ambientais permaneceram anos sem serem completamente entregues. Todos eles eram inaugurados parcialmente, como já mostrava o Jornal Folha de São Paulo no ano de 2005:

Quase um ano depois de inaugurados, sete parques públicos da cidade de São Paulo continuam inacabados. Entregues no apagar das luzes da administração Marta Suplicy (PT), os parques ainda precisam de instalações paisagísticas, quadras e playgrounds para se aproximar dos projetos originais $^{195}$. 
Entre os anos de 2007 e 2008, esse problema foi parcialmente resolvido com a entrega final dos parques do Cordeiro (setembro de 2007), Jacintho Alberto e Vila Prudente (janeiro de 2008).

A respeito dessa fragmentação de recursos, o Arq. Raul Pereira ${ }^{196}$ comenta duas experiências distintas que obteve em seu trabalho com as compensações ambientais. Ele cita o caso do projeto paisagístico para o Parque Jacintho Alberto, custeado por diversos empreendimentos do entorno. Embora tenha sido custeado por vários TCAs, o fato das obras de origem apresentarem características semelhantes (uso residencial) permitiu que estes fossem agrupados em mãos de um único empreendedor, que era responsável por repassar o valor aos beneficiários.

$\mathrm{O}$ arquiteto vivenciou o processo oposto com o projeto paisagístico do Parque do Cordeiro, cuja data de início (2003) era semelhante ao Parque Jacintho Alberto. No caso do Cordeiro, os recursos vieram de fontes bastante distintas: empreendimentos privados (residenciais) e públicos (corredor de ônibus da Av. Ibirapuera). Além da diferença nas fontes de custeio, o parque apresentou problemas fundiários que suspenderam temporariamente sua execução e fizeram com que os recursos chegassem em diferentes momentos.

Segundo Raul, o processo utilizado no Parque Jacintho Alberto agilizou o andamento do projeto, pois reduziu a quantidade de atores intermediários. Por outro lado, a forma de custeio adotada no Parque do Cordeiro gerou não só atrasos, como também diversos problemas de incompatibilidades na obra. Infelizmente, o caso do Parque Jacintho Alberto constitui uma exceção.

Percebe-se, portanto, que o agrupamento de compensações de modo a formar montantes suficientes para custear obras poderia ser uma solução para esse problema. Kawai explica que já havia sido cogitada pelo DEPAVE a criação de uma espécie de "consórcio" envolvendo compensações ambientais de características distintas, na qual se criaria um estoque de verbas direcionado para um determinado fim. Mas, segundo ela, o processo jurídico para remembramento dessas verbas, que envolve diferentes tipos de empreendedores, era bastante complicado e inviabilizou tal proposta. 
Segundo o Eng. Belmiro Andrade, coordenador executivo da Câmara de Compensação Ambiental da SVMA ${ }^{197}$, outro fator que dificulta o agrupamento dos recursos provenientes de TCAs é o modo como se vincula o mecanismo ao processo de aprovação dos empreendimentos. Em 2008, a conclusão de uma obra é atrelada ao fechamento do seu processo de compensações ambientais (para melhor entendimento, consultar fluxograma de aprovação dos TCAs no apêndice deste trabalho). Dificilmente a SVMA consegue conciliar a época de pagamento de compensações provenientes de empreendimentos distintos. $\mathrm{O}$ agrupamento de recursos só seria possível caso o empreendedor consentisse em adiar a conclusão da sua obra para aguardar o agrupamento de recursos provenientes de outras compensações. Naturalmente, nenhum empreendedor está disposto a tal sacrifício. Desse modo, a SVMA se vê obrigada a investir os recursos de TCAs antes que se consiga agrupá-los em montantes convenientes para a execução de obras como parques ou praças.

Apesar dessas restrições, as compensações têm potencial para gerar constantemente novos recursos. Até mesmo se, por hipótese, fosse retirada toda vegetação legalmente passível de corte na cidade. Nessa situação restariam ainda os casos de reposição de árvores velhas ou com estado fitossanitário ruim, uma das atribuições das compensações ambientais em São Paulo. Até o ano de 2008, tais casos não têm sido atendidos de forma adequada pela prefeitura. Essa deficiência na manutenção e monitoramento ocasiona anualmente a queda dezenas de árvores no município, colocando em risco a população ${ }^{198}$.

\section{População e os TCAs: uma seqüência de mal-entendidos}

A responsabilidade pelo não atendimento da demanda de cortes e podas em São Paulo não se deve exclusivamente ao Poder Público. Ao polemizar a retirada de qualquer árvore, a opinião pública pode dificultar ações necessárias do Poder Público. Permeia no imaginário da população a visão ingênua de que qualquer corte de árvore representa uma perda para 
Essa situação é bem ilustrada pelo seguinte caso:

A derrubada de sete árvores na esquina da Alameda Jaú com a Praça Alexandre de Gusmão provocou indignação e confusão no domingo passado. Apesar das suspeitas de todos os que testemunhavam o corte quanto à legitimidade do procedimento, as árvores foram derrubadas com a devida autorização, concedida através do Termo de Compromisso Ambiental [...]

Segundo o Sr. Cícero, coordenador do DEPAVE-GNC, a autorização foi concedida em total concordância ao estabelecido na Lei 10.365/87, que prevê o corte de árvores quanto estas estiverem causando danos ao patrimônio. O condomínio alegou, ao solicitar a autorização, que o enraizamento estava danificando a caixa d'água do edifício, o que foi constatado pela inspeção do DEPAVE. Segundo o Sr. Cícero, as raízes dessa espécie, ficus, são muito agressivas. Questionado quanto ao fato da árvore já estar lá antes da construção do edifício, o Sr. Cícero afirmou que 'não há referencia, no processo, a que o prédio tenha sido construído antes ou depois da árvore'.

O Termo de Compromisso Ambiental obriga ao edifício a plantar - em um prazo de seis meses após a publicação do TCA no Diário Oficial- três árvores nativas com raízes não agressivas, no local ou nas proximidades, e a fornecer oito exemplares, e seus respectivos protetores metálicos, para o Viveiro Manequinho Lopes (no Parque do Ibirapuera), que serão plantadas pela Regional de Pinheiros. Só? Segundo o Sr. Cícero, a Lei prevê que caso as árvores cedidas não sejam replantadas no local, o requerente deverá doar duas mudas para cada árvore cortada [...]. ${ }^{199}$

Outro caso é citado por Miranda Magnolli, em seu trabalho de compensação ambiental para o Hospital Alemão Osvaldo Cruz ${ }^{200}$. Análises técnicas de duas paineiras existentes no terreno dessa obra indicavam a necessidade de cortá-las, devido ao estado fitossanitário ruim. O pedido de remoção foi aprovado pelo DEPAVE. No dia da retirada das paineiras, a população do entorno reuniu-se para evitar sua retirada. Depois de bastante polêmica e protestos, as árvores foram cortadas. Quando o miolo do tronco ficou exposto, o apodrecimento devido à ação de cupins ficou evidente, e permitiu que a população entendesse a necessidade do corte.
199. Jornal eletrônico “Sampa On-line”, 12 de Outubro de 2001 200. Todas as informações citadas neste capítulo referem-se à entrevista realizada com a arquiteta paisagista em 04.03.2007. 
201. São elas, em ordem decrescente de contribuição: Parelheiros, Socorro, Perus, Tremembé/ Jaçanã, São Mateus, Ermelino Matarazzo e Campo Limpo. SÃO PAULO (cidade).

Secretaria do Verde e do Meio Ambiente. IPT. GEO cidade de São Paulo: panorama do meio ambiente urbano. Brasília: PNUMA, 2004. p.68

202. Estimativa realizada pelo autor com base na quantidade efetiva de supressões autorizadas disponibilizadas pelo DEPAVE no volume "Geo São Paulo" (Ibidem, p.68). Considerou-se que as árvores suprimidas tivessem em média $10 \mathrm{~m}$ de diâmetro de copa e área de projeção aproximada de $75 \mathrm{~m}$ cada.

203. Ibidem, p. 69.
Caso essa árvore caísse devido à falta dessa manutenção realizada, certamente também ocorreriam protestos. Magnoli refere-se a essa situação como um caso ambíguo, no qual a população critica o Poder Público tanto pela retirada quanto pela manutenção das árvores em seus lugares. Não se deseja aqui, desmerecer o papel da sociedade organizada no controle da degradação ambiental do município. Este tipo de ação tem trazido melhorias para a cidade e precisa não só ser mantido como ampliado. Mas é necessário o esclarecimento adequado a respeito daquilo que está sendo reivindicado.

\section{“Descompensações” paralelas}

Enquanto a mídia e a opinião pública focam suas críticas na parcela mais visível dos casos de cortes de árvores legalmente autorizados na cidade, as remoções ilegais ocorrem em proporções muito maiores nas áreas periféricas do município.

Dados do IPT mostram que entre os anos de 1997 e 2001, todos os sete distritos com maior redução de cobertura arbórea localizavam-se em Subprefeituras periféricas do município ${ }^{201}$. Em conjunto, esses locais somaram um total de 230 hectares de desmatamento, sendo 138,50 deles na Subprefeitura de Parelheiros. Nesse mesmo período (1997-2001), a SVMA estima que tenham sido autorizados cerca de 8.600 cortes de árvores em função de compensações ambientais, o equivalente a cerca de 65 hectares ${ }^{202}$. A maioria dessas supressões autorizadas ocorreu em regiões centrais do município, onde a ação fiscalizadora do Poder Público é mais efetiva.

Existem serviços ilegais de corte e poda que cobram quantias consideráveis por essa atividade.É possível identificar nas ruas de São Paulo faixas oferecendo retirada de árvores mediante pagamento de valores pré-estabelecidos. A disponibilização e facilidade de acesso a serviços ilegais como esse é um subproduto da ineficiência da fiscalização por parte do Poder Público. Dados da Polícia Militar Ambiental do Estado de São Paulo mostram que no ano de 2002, apenas quatro casos de supressão ilegal de árvores imunes a corte resultaram em autuação $0^{203}$. 
Tal situação também fica evidenciada no trecho a seguir:

A fiscalização é tão pífia que não chega a inibir os cortadores. Tanto o Departamento de Parques e Áreas Verdes do município (Depave) como a Delegacia do Meio Ambiente estadual não sabem informar quando foi a última vez em que alguém foi preso em flagrante cometendo o delito. Denúncias são freqüentes. No último Carnaval, o Depave recebeu uma ligação sobre cortes irregulares na Avenida Jornalista Roberto Marinho. Quando a polícia ambiental chegou, o autor do crime já havia fugido. Deixou um saldo de 48 árvores derrubadas. Ele foi identificado e está respondendo a processo em liberdade ${ }^{204}$.

\section{Compensações políticas}

Ao longo de seu desenvolvimento no Município de São Paulo, as compensações ambientais mostraram-se suscetíveis às mudanças de postura de cada gestão. A confrontação do texto da lei com a realidade da época na qual este foi alterado evidencia mudanças ocorridas em função de interesses políticos. Situações ocorridas em diferentes gestões exemplificam essa subordinação da legislação aos interesses políticos de cada época.

A necessidade de finalizar as obras de parques públicos prioritários para a Gestão Marta Suplicy foi um dos fatores que motivaram o aumento da possibilidade de compensação por obras e serviços por meio da Portaria DEPAVE 136/2003.

A redução da proporção compensatória para eucaliptos e pinus levada a efeito na Gestão Serra/ Kassab através da Portaria DEPAVE 005/2006 vai ao encontro das pressões do mercado imobiliário, pois como já foi mencionado, esse é o tipo de vegetação arbórea mais freqüentemente encontrado nos terrenos ainda disponíveis na Cidade de São Paulo.

\section{Um mecanismo "Robin Wood"?}

Embora as compensações ambientais possam contribuir para atenuar as desigualdades na distribuição de espaços livres na cidade, sua utilização inadequada pode surtir o efeito oposto, dependendo do local onde é realizada.
204. MONTEIRO, Lúcia. $R \$ \$ 350,00$. E lá se vai mais uma árvore. Esse foi o valor pedido por um cortador irregular para derrubar o fícus da foto abaixo. Revista Veja São Paulo. 21.04.2004 
Por princípio, os processos compensatórios sempre buscam gerar quantidades de mudas maiores do que a quantia de árvores retirada por um empreendimento. Caso esse excedente seja plantado no entorno que já possui arborização satisfatória, satura-se um local com plantio enquanto as demais regiões da cidade continuam perdendo sistematicamente sua cobertura arbórea. Magnolli sintetiza essa situação ao dizer que, com relação às áreas arborizadas da cidade de São Paulo, “o lugar que não tem vai continuar não tendo e o lugar que tem vai ter cada vez mais" 205 . Para Magnoli, a compensação proveniente de áreas mais arborizadas deveria ser utilizada pela SVMA em locais reconhecidamente mais carentes, como a zona leste do município. Isso auxiliaria na atenuação dessa desigualdade.

Essa visão mais global das compensações, que considera a cidade como um sistema de espaços livres, ainda não encontra repercussão junto a uma parte significativa de profissionais do Poder Público. Nos anos de 2005 e 2006, período inicial da Gestão Serra/ Kassab), defendia-se a compensação pelo plantio de mudas no entorno próximo mesmo quando este já se encontrava saturado de árvores.

\section{Onde plantar?}

O Arq. Caio Boucinhas, relata que no ano de 2001 - época na qual foi diretor do DEPAVE - a procura por locais para plantar as árvores de TCAs era um dos principais problemas enfrentados por Subprefeituras como Santo Amaro ${ }^{206}$. Existem casos de compensação nos quais simplesmente não há espaço físico disponível para a locação de todas as árvores solicitadas pela prefeitura ao empreendedor.

Situações como essa levam ao contra-senso do Poder Público ter disponível uma quantia considerável de mudas para plantio sem saber onde plantá-las. Como resultado, usualmente adota-se dois tipos de solução para cumprir as obrigações previstas pela lei.

Uma delas consiste no plantio das mudas nos espaços livres públicos que ainda restaram na circunscrição da Subprefeitura. Geralmente são locais de pouca ou nenhuma relevância, como áreas residuais do sistema viário e rotatórias. Além de não contribuírem para a melhoria do sistema de espaços livres da cidade, a chance de sobrevivência das mudas 
nesses locais é bastante reduzida, dado o usual estado de abandono que se encontram e a maior suscetibilidade às ações de vandalismo.

Em outros casos, a Subprefeitura escolhe os locais com maior visibilidade, mesmo que estes já possuam arborização significativa. Isso leva a uma saturação de plantio que também pode ser prejudicial, pois, em casos mais extremos, pode impossibilitar o crescimento adequado das mudas, devido à indisponibilidade de espaço para seu desenvolvimento.

Essas duas medidas resultam do entendimento da compensação ambiental por critérios numéricos e burocráticos. Enquanto isso, uma considerável porção da cidade permanece com carência de arborização.

Esse problema para identificação das áreas a compensar deve-se à inexistência de um plano de espaços livres e arborização para o município e a uma gestão deficiente do processo. Esta opinião é compartilhada não só pelos profissionais do próprio Poder Público, como também pelos envolvidos nas diversas etapas das compensações ambientais no município.

Gobbi, profissional responsável pela implantação de uma compensação no bairro de Brooklin Novo (circunscrição da Subprefeitura de Santo Amaro), relata problemas com a demora para definição da área compensatória, visto que o entorno já era densamente arborizado. Para ele, caso existisse um mapeamento pré-existente das áreas que necessitam de arborização no município, esse problema poderia ser solucionado. Gobbi complementa esse raciocínio sugerindo que a definição das áreas deveria ser acompanhada de um mapeamento dos locais com maior aceitação à arborização urbana, criando possibilidades maiores de efetivação da mesma devido ao comprometimento estabelecido com moradores do entorno.

Poucas foram na história da cidade, até o ano de 2008, as iniciativas de identificação de áreas potenciais para arborização e espaços livres públicos em São Paulo. Dentre elas, pode-se destacar: o plano de áreas verdes de 1967; o volume "Vegetação Significativa do Município”, de 1988 e o Plano Diretor Estratégico de 2002. 
O plano de áreas verdes de 1967 encontra-se em absoluto descompasso com a realidade do município quarenta anos depois, embora apresente metodologia que pode ser aproveitada. O volume "Vegetação Significativa" apresenta problema semelhante ao Plano de Áreas Verdes. O Plano Diretor Estratégico de 2002 descreve a necessidade de um mapeamento, ao definir como ação estratégica "elaborar mapa de áreas verdes do Município, identificando em cada distrito as áreas do Sistema de Áreas Verdes." 207

É difícil conceber que um município do porte de São Paulo não possua identificação detalhada e atualizada dos espaços livres potenciais. Um estudo detalhado para identificação das atuais áreas poderia ser custeado pelas próprias compensações ambientais.

\section{Plantio compensatório: uma alternativa em xeque}

Embora a compensação por plantio constituísse inicialmente (e durante um bom tempo) a prioridade máxima para o Poder Público, as dificuldades encontradas no processo fizeram ser revisto o papel que esta deveria desempenhar. A idealização do plantio como forma de recuperação dos danos ambientais pela retirada de árvores foi quebrada pelo seu rebatimento na realidade do cotidiano. Diversas experiências corroboraram para essa constatação.

É o caso das quantias compensatórias pequenas, que costumam representar um problema para a SVMA e o DEPAVE. Números maiores de árvores para compensação representam montantes financeiros mais facilmente aplicáveis, sobretudo quando a medida exigida é alternativa ao plantio (caso das obras e serviços).

Mas quando a quantia compensatória é muito pequena, há maiores dificuldades para identificar locais específicos para aplicá-las. Além disso, plantios em quantias muito pequenas têm menor possibilidade de suportar atos de vandalismo e apresentam pouca significância no contexto geral da cidade. Mesmo que sejam convertidos em obras civis, valores reduzidos apresentam dificuldade em serem aplicados. 
Por esses motivos, a partir de 2006 a Câmara de Compensação Ambiental da SVMA passou a analisar apenas os casos que envolvessem quantias compensatórias superiores a 200 mudas $^{208}$. Valores inferiores a esse são diretamente, em 2008, são convertidos em doação de mudas ao viveiro municipal.

Outra solução possível para o problema seria agrupar recursos provenientes de TCAs com pequenas quantias de modo a torná-los significativos para aplicação em medidas compensatórias de maior porte. As maiores dificuldades encontradas nesse sentido, como já foi mencionado, referem-se à articulação jurídica para viabilização.

Perdas ocorridas com depredação também figuram entre os maiores obstáculos encontrados pelas compensações por plantio. Ao relatar um caso de compensação ambiental realizada por sua empresa no bairro do Brooklin Novo, Gobbi cita perdas com vandalismo na ordem de 30\% das mudas plantadas. Essa quantidade é considerada, diante da experiência de Manuel, um valor corriqueiro. Kawai afirma já ter trabalhado com perdas de até $50 \%$ em função da depredação.

A falta de consciência de moradores em relação ao plantio compensatório nas vizinhanças não necessariamente resulta do seu nível de instrução ou renda - como poderia ser pensado de forma apriorista.

Magnolli, ao falar sobre seu projeto de compensação ambiental para o Hospital Alemão Osvaldo Cruz, cita um caso representativo das relações dos moradores com mudas recémplantadas. Ao mapear a efetividade do plantio compensatório realizado no bairro da Bela Vista, a arquiteta pôde presenciar moradores de edifícios de classe média levando seus cachorros para urinar nas árvores recém plantadas. E há poucos metros desse local, observou moradores de cortiços do entorno assumindo a responsabilidade pela manutenção de mudas na mesma condição.

Gobbi afirma que o plantio de mudas de TCAs no Brooklin Novo foi um dos trabalhos que mais the causaram problema com depredação, sobretudo devido às ações de vandalismo dos jovens de classe média que freqüentam danceterias da região da Vila Olímpia. Por
208. Equivalente a cerca de $R \$ 52.000,00$, segundo o valor da muda de R\$268,12, estabelecido pela SVMA em fevereiro de 2008 Informações fornecidas em entrevista realizada em 31.01.2008 com ong. Civil Belmiro Andrade, coordenador executivo da Câmara de Compensação Ambiental da SVMA. 
outro lado, um dos casos mais bem sucedidos trabalhado por Manuel ocorreu no bairro de Brasilândia, bairro de baixa renda no qual a população estabeleceu vínculos com a vegetação plantada.

Depreende-se desses dois exemplos, que o sucesso do plantio reside em grande parte do nível de conscientização dos envolvidos e do estabelecimento de vínculos de responsabilidade dos moradores com as árvores que foram plantadas. Nesse sentido, a educação ambiental também desempenha um papel importante na efetividade das ações de compensação. A geógrafa Ana Beatriz Goshuen, participante da Sociedade Amigos do Jardim Petrópolis e dos Estados (SAJAPE), considera que dificilmente as ações de plantio compensatório evoluirão sem que haja trabalhos pedagógicos a elas vinculados.

O custeio de projetos de educação ambiental como modalidade compensatória está prevista desde a Portaria 009/2005. Poucas ações, no entanto, foram efetivadas até o ano de 2008. Kawai atribui tal fato à dificuldade no estabelecimento de parâmetros de trabalho para profissionais da iniciativa privada. $\mathrm{O}$ controle das ações exigiria um trabalho mais aprofundado do DEPAVE nessa área, sendo que o departamento sequer consegue dar conta das atuais atribuições existentes.

\section{Fiscalização x manutenção: reflexo de conflitos entre poder público e o empreendedor}

A baixa efetividade das ações de plantio compensatório guarda relação com outro problema grave a ser considerado: a ineficiência na fiscalização do plantio compensatório por parte da SVMA e DEPAVE. A legislação vigente no ano de $2008^{209}$ estabelece prazo de até dois anos para manutenção por parte do empreendedor das mudas compensatórias plantadas. Essa ação visa permitir a consolidação das árvores até que estas atinjam porte significativo e resistam por si próprias aos diversos agentes agressivos aos quais estão submetidas no meio urbano.

Não existe, no entanto, quantidade de técnicos fiscalizadores suficiente para garantir que o empreendedor cumpra o prazo previsto pela legislação compensatória. Considerando-se a 
restritas em função da quantidade reduzida de funcionários para fiscalização. O Eng. Agr. Ricardo Borgianni ${ }^{210}$ afirma que, desde a aplicação das compensações no município até o ano de 2006, apenas uma obra havia sido vistoriada após o período de manutenção obrigatória previsto pela legislação ${ }^{211}$.

A fiscalização adequada não só contribuiria para aumentar a efetividade da aplicação de compensações ambientais como também permitiria a maior proteção ambiental dos limites do município. Reciprocamente, os recursos obtidos desse modo podem auxiliar a atenuar a degradação existente.

Somam-se ao problema da fiscalização as dificuldades encontradas pelo próprio empreendedor. Enfrentam-se grandes dificuldades em manter as mudas compensatórias em condições adequadas em meio às constantes ações de vandalismo. Silva Filho relata que diversas vezes o empreendedor simplesmente opta por deixar a muda perecer e ao final do prazo de dois anos, substitui por outra.

O pouco contato estabelecido pelos técnicos representantes do Poder Público com as obras compensatórias também dá margem a diversos equívocos. Gobbi cita o caso de uma compensação ambiental realizada no bairro paulistano de Santa Cruz. A obra envolveu o transplante de algumas mudas autorizadas pelo DEPAVE. Em determinado momento da obra as mudas para transplante foram armazenadas em local não previsto. Ao realizar vistoria e não encontrar as mudas para transplante, o funcionário do DEPAVE aplicou multa ao empreendedor. A introdução da exigência de relatórios fotográficos para acompanhamento da manutenção das mudas, estabelecida pela SVMA a partir do TCA do Hospital Alemão Osvaldo Cruz, constitui uma alternativa para amenizar o problema.

O transplante de mudas como forma de compensação, antes priorizado, passa a ser encarado com cautela pela SVMA. Embora não se tenha fornecido dados numéricos a respeito, a direção do DEPAVE considera baixa a porcentagem de árvores que sobrevivem aos transplantes. Além de delicado, o transplante costuma envolver mobilização de equipamentos que representam grandes custos para os envolvidos e sobrecarga de trabalho
210. Apontamentos pessoais da palestra "Aplicação das Leis Municipais de Compensação Ambiental" realizada pelo engenheiro na Associação Nacional de Paisagismo em 27.04.2006.

211. De acordo com informações obtidas na SVMA, o acompanhamento adequado de um TCA envolveria no mínimo duas vistorias à obra: uma quando finalizados os plantios compensatórios e transplantes e outra ao término do prazo obrigatório de manutenção, para verificação das condições das mudas plantadas. Alem destas, podem ser necessárias diversas outras vistorias em função do cumprimento inadequado das obrigações previstas, até que o empreendedor realize a contento o que foi solicitado pela SVMA. 
para os fiscais do Poder Público. Estes custos poderiam ser direcionados de formas mais efetivas para a melhoria do sistema de espaços livres do município. E o processo de transplante pode dar margem a diversos equívocos, como foi citado anteriormente.

\section{Novas Alternativas}

Pelos diversos motivos anteriormente citados, a SVMA e o DEPAVE alteraram a forma prioritária de compensação ambiental usada desde 2005. O uso do plantio e do transplante como formas compensatórias era muito custoso ao Poder Público, devido ao baixo índice de sobrevivência das mudas.

No ano de 2007, Kawai afirma que as modalidades compensatórias prioritárias em São Paulo passaram a ser para obras e serviços, sobretudo os relacionados à implantação de novos parques lineares na cidade. Kawai considera que esse tipo de ação é mais duradoura e menos custosa ao Poder Público, devido à sua efetividade. Essa opinião é compartilhada por Boucinhas, que considera a execução de obras menos suscetível ao vandalismo do que o plantio. Para ele, a ação de plantio é mais frágil por envolver seres vivos, que requerem maiores cuidados do que elementos construtivos. Embora o plantio apresente dificuldades em sua manutenção, esses profissionais reconhecem que ele é (e precisa continuar sendo) a base do processo compensatório.

Uma alternativa ao plantio é a doação de áreas privadas arborizadas ao Poder Público. Essa modalidade compensatória, segundo o Eng. Agr. Marcelo Cocco $^{212}$, possui importância equivalente ao plantio, pois entrega ao Poder Público a tutela de uma área com árvores de porte adulto, resguardando-a da atuação predatória do mercado imobiliário. Kawai cita como exemplo desse tipo de ação o caso pioneiro de um empreendedor que doou um terreno no bairro de Itaim Paulista como forma de compensação de danos ambientais provocados por uma obra na região sudoeste da cidade. Apesar dessa experiência bem sucedida, Célia considera que as dificuldades jurídicas em incorporar um terreno privado como bem público constitui um grande obstáculo a ser vencido para a ampliação no uso desse tipo de medida. 
A doação de mudas ao viveiro da prefeitura também passou a desempenhar um papel mais relevante em substituição ao plantio feito diretamente pelo empreendedor. Tal medida permite que a SVMA e o DEPAVE armazenem um estoque de mudas a ser plantado no momento adequado.

Mas dependendo da situação, a doação de mudas pode trazer problemas ao Poder Público. Belmiro Andrade afirma que existem diversos casos nos quais a quantia de mudas a serem fornecidas ao viveiro municipal extrapola em muito a sua capacidade ${ }^{213}$, mesmo que se exija a entrega gradativa, em diferentes momentos. Esse excedente também ocorre com os protetores solicitados juntamente às mudas compensatórias. Tal fato levou a SVMA a modificar as proporções estabelecidas pela legislação entre a quantidade de mudas e protetores, de modo a reduzir a quantia deste último, quando necessário.

Outra forma de controlar o estoque de mudas disponíveis para compensação é a solicitação de maiores portes ( 5 e $7 \mathrm{~cm}$ de DAP, ao invés do mínimo de $3 \mathrm{~cm}$ estabelecido pela legislação). Ao fornecer mudas maiores, o DEPAVE reduz a quantidade total a ser fornecida pelo empreendedor, em função dos ganhos em qualidade e ao custo superior desses indivíduos. Ao reduzir a quantidade de mudas solicitadas, possibilita-se o melhor controle do estoque de mudas disponíveis para compensação, que apresenta demandas flutuantes.

\section{A relação com os viveiristas}

A relação entre a prefeitura e os viveiristas privados ainda é passível de diversos aperfeiçoamentos. A obtenção de mudas para uso em projetos públicos junto a viveiros privados iniciou-se em São Paulo em meados da década de 1970. A respeito das razões que motivaram o surgimento desses viveiros, Steschenko diz que "a ênfase dada à utilização da vegetação nativa no paisagismo na década de $1970 \mathrm{fez} \mathrm{com} \mathrm{que} \mathrm{surgissem} \mathrm{os} \mathrm{primeiros}$ viveiros comerciais especializados em essências nativas" ${ }^{214}$. Mas a sintonia da produção dos viveiros com a demanda existente no mercado ocorreria posteriormente, visto que "em São Paulo, somente em meados da década de 1980 que os viveiros comerciais começaram a oferecer mudas com porte razoável para serem utilizadas em projetos paisagísticos" ${ }^{215}$.
213. De acordo com informações fornecidas pela equipe do DEPAVE 2 em fevereiro de 2008, o Viveiro Municipal Manequinho Lopes possui capacidade para armazenar, de uma só vez, cerca de 10.000 mudas. Como existem compensações cujas quantidades capacidade do viveiro, tornam-se necessários ajustes de logística com as Subprefeituras que receberão as árvores.

214. STESCHENKO, Wolfgang Sergio. Contribuição ao estudo e ao processo de produção da praça pública paulistana - o Departamento de Parques de Parques e Áreas Verdes de São Paulo de 1967 a 1979. Dissertação de Mestrado. São Paulo, FAUUSP, 2001. p. 55

215. Ibidem. 
Embora tenha experimentado melhorias, o fornecimento de mudas por viveiristas ainda não se encontra plenamente adaptado à realidade das compensações ambientais. A legislação vigente exige mudas com porte mínimo de $2,50 \mathrm{~m}$, diâmetro de altura de peito de $3 \mathrm{~cm}$ e primeiras ramificações a $1,80 \mathrm{~m}$ do nível do colo, condições estabelecidas para conferir algum nível de resistência às possíveis ações de vandalismo. Essas especificações nem sempre são encontradas no mercado para todas as espécies arbóreas constantes da listagem oficial divulgada pelo DEPAVE ${ }^{216}$. Todas as mudas constantes nesse documento são nativas, reminiscência positiva do nacionalismo que permeava o ideário do DEPAVE na década de 1970. Mas ao contrário dos princípios estabelecidos pela prefeitura, as espécies mais solicitadas pelo mercado de mudas são aquelas ditadas pelos modismos, em sua maior parte exóticas.

A solução para o problema da escassez de mudas nativas para compensação ambiental envolve mudanças em sua dinâmica. Para o viveirista Walter Doering ${ }^{217}$, o preparo das mudas compensatórias deve ser feito de forma antecipada, ainda na fase de aprovação do empreendimento, de modo que as árvores atinjam o porte estabelecido na época de sua implantação. Tal idéia é fruto do trabalho conjunto do viveirista com Miranda Magnolli para o Hospital Alemão Osvaldo Cruz. Segundo Doering, além de permitir o melhor planejamento do plantio compensatório, a ação proposta possibilita que o empreendedor parcele o pagamento da compensação ao longo do tempo de preparo das mudas, que dura em média um ano.Permite também reduzir os custos do empreendedor com compensações, visto que o preço para aquisição de mudas é diretamente proporcional ao seu porte. Mudas plantadas com bastante antecedência reduzem substancialmente seus custos de aquisição.

Embora apresente potencial, a viabilização desse sistema proposto depende de ações do Poder Público. O preparo antecipado de mudas só é possível por meio do andamento mais linear do processo compensatório, associado a um cronograma efetivo de implantação de novos projetos públicos. É necessário que o Poder Público forneça ao empreendedor garantias suficientes para justificar o investimento em uma estrutura própria para produção de mudas. Tal fato não tem ocorrido desde o surgimento do mecanismo. 


\section{Entraves burocráticos}

Kawai afirmou, em 2007, que o tempo de tramitação dos processos compensatórios em São Paulo não apresenta um padrão definido. Processos envolvendo compensação de maior porte circulam pelo departamento desde a Gestão Marta Suplicy (2000-2004), enquanto a aprovação de casos menores pode ser resolvida em poucos meses. $\mathrm{O}$ modo como o empreendedor responde às exigências do Poder Público influi no tempo de aprovação.

Mas até mesmo os casos no qual são acatadas todas as solicitações da prefeitura estão suscetíveis a entraves, que podem decorrer da condução inadequada do processo pelo próprio Poder Público. Gobbi relata que diversas vezes encontrou dificuldades com o andamento de compensações ambientais devido à desorganização do departamento responsável. Ele cita um caso no qual seu processo simplesmente foi perdido em meio ao trâmite entre as repartições responsáveis. Apesar de possuir documentos comprobatórios da entrega do processo à prefeitura, Gobbi foi obrigado a dar entrada em um novo processo, visto que o departamento alegava não ter subsídios suficientes para aprovar seu caso.

Outro caso emblemático é relatado pelo Eng. Agr. André Ostermayer. Segundo ele, sua empresa:

[...] teve cerca de 120 mudas apreendidas por técnicos da prefeitura quando tentava colocá-las nos canteiros centrais da Avenida 23 de Maio. Ele e cinco técnicos de sua equipe foram ameaçados de prisão. Estavam apenas cumprindo uma determinação do próprio município: apresentar 450 mudas na região da Bela Vista como compensação pelo corte de árvores provocado pela construção de um condomínio. $^{218}$

Fatos como esses provam que a sofisticação adquirida pela legislação de compensação ambiental do município não significa que já exista estrutura adequada para aplicá-la.

Apesar disso, os conhecimentos adquiridos pela SVMA e DEPAVE ao longo de dez anos de experiência na aplicação das compensações começam a surtir efeito. A tabela a ao lado, elaborada pela SVMA, evidencia uma contínua redução do tempo necessário aos processos de aprovação das compensações no município de São Paulo:
Tabela 19. Tempo para conclusão dos processos de compensação ambiental arbórea em São Paulo entre 1997 e 2005

\begin{tabular}{|c|c|}
\hline data & $\begin{array}{c}\text { tempo médio de conclusão } \\
\text { de um TCA (em anos) }\end{array}$ \\
\hline 1997 & 5,98 \\
\hline 1998 & 5,79 \\
\hline 1999 & 5,00 \\
\hline 2000 & 3,13 \\
\hline 2001 & 3,46 \\
\hline 2002 & 3,49 \\
\hline 2003 & 2,74 \\
\hline 2004 & 2,74 \\
\hline 2005 & 2,47 \\
\hline
\end{tabular}

Fonte: SVMA (2008)

218. SOARES, Sandra. O Quebra Galho : Há uma árvore no meio do caminho? Chame André Ostermayer. Revista Veja São Paulo. 19 Abril 2006. p.30 


\section{Atores e ações}

A viabilização das compensações ambientais envolve uma gama variada de profissionais cujas atuações, diversas vezes, entram em conflitos.

\section{Poder Público: a relação entre departamentos}

O Poder Público naturalmente não constitui um todo homogêneo. Há diversas diferenças entre escalas de atuação e abordagens. Dependendo do tipo de compensação ambiental realizada, o processo pode envolver, além da Secretaria Municipal do Verde e Meio Ambiente:

- Representantes do Departamento Estadual de Proteção aos Recursos Naturais (DEPRN), vinculado à Secretaria do Meio Ambiente (SMA) do governo estadual, para os casos de compensações de maior porte.

- Técnicos das Subprefeituras do município, para os casos de menor porte.

- Profissionais da Secretaria Municipal de Habitação, que atuam logo no início do processo de aprovação de empreendimentos.

As interações entre profissionais do DEPRN e DEPAVE nos processos de aprovação da área ambiental são definidas basicamente pelo Decreto Estadual 39.743/94 e pelo Código Florestal $^{219}$, que estabelecem as atuações de cada um desses departamentos. Embora estejam legalmente definidas, as competências de cada um desses órgãos nem sempre são tão claras na atuação do dia-a-dia.

Gobbi relata situações de empreendedores mal instruídos pelo Poder Público, que foram prejudicados por não saber exatamente a quem a aprovação deveria ser solicitada. É o caso de uma obra no bairro do Morumbi, no qual o empreendedor encaminhou o processo para o DEPAVE, mas descobriu, depois de diversos problemas, que deveria ter recorrido em primeiro lugar ao DEPRN. 
de processos envolvendo florestas e áreas agrícolas, estando pouco habilitado a responder pelos casos que envolvam a escala municipal. A falta de articulação do DEPRN com relação à inserção urbana faz com que muitas vezes sejam escolhidas áreas desinteressantes para realizar a compensação.

Outro problema apontado pelos técnicos entrevistados para esta pesquisa é a quantidade reduzida de funcionários do DEPRN para realizar a aprovação dos casos compensatórios. Silva Filho afirma que, em 2005, "essa equipe possui somente um técnico para realizar a análise de pedidos de intervenção em vegetação.” na cidade de São Paulo. ${ }^{220}$ Como resultado da quantidade reduzida de profissionais, o autor refere-se a um "longo tempo de permanência desses processos no DEPRN, justificado por uma estrutura não dimensionada para questões que têm a escala do município"221

Estes mesmos problemas são apontados por Silva Filho na atuação do IBAMA ${ }^{222}$, órgão federal que atua conjuntamente à SMA e SVMA na aplicação da legislação de proteção à vegetação na cidade de São Paulo.

A divergência quanto às posturas para aprovação também leva a diversas dificuldades no trâmite dos processos. Silva Filho cita em sua tese o caso de aprovação de um conjunto habitacional na divisa com o Parque Estadual do Pico do Jaraguá, no qual "foi autorizado, pelo IBAMA, o calçamento ao redor de uma nascente e a ocupação de metade da faixa de preservação permanente" 223 , postura que ia de encontro ao definido pelo DEPAVE para a mesma área, mas acabou sendo acatada.

As atuações dentro do próprio município também estão sujeitas a diversos conflitos. O DEPAVE divide a responsabilidade de aplicação das compensações ambientais no município com as Subprefeituras, mais especificamente com o setor técnico "Unidades de Áreas Verdes". Técnicos entrevistados para este trabalho relataram que há casos de pouca interação entre as equipes das Subprefeituras e o DEPAVE devido a uma postura de distanciamento. Segundo eles, alguns técnicos do departamento temem perder um suposto "status" em relação às unidades administrativas de menor porte - no caso, as Subprefeituras.
220. SILVA FILHO, Carlos Alberto da. Proteção e fomento da vegetação no Município de São Paulo: possibilidades, alcance e conflitos. Tese de doutorado. São Paulo, FAUUSP, 2005.

221. Ibidem.

222. Ibidem

223. SILVA FILHO, Carlos Alberto da. Proteção e fomento da vegetação no Município de São Paulo: possibilidades, alcance conflitos. Tese de doutorado. São Paulo, FAUUSP, 2005. 


\section{As diferentes posturas profissionais no Poder Público}

Além das diferentes escalas de atuação, o processo de aprovação das compensações ambientais no Poder Público envolve profissionais de diferentes áreas do conhecimento. Os arquitetos e os engenheiros agrônomos constituem os grupos profissionais mais representativos no funcionamento das compensações ambientais em São Paulo.

As atuações destas duas categorias profissionais complementam-se. A maior contribuição da área de arquitetura refere-se ao entendimento da cidade como um conjunto articulado de espaços, livres ou construídos. O reconhecimento dessa atuação é compartilhado inclusive por engenheiros agrônomos da prefeitura, como Silva Filho. As áreas de engenharia agronômica e florestal detêm conhecimentos técnicos fundamentais aos processos que envolvem vegetação. O fato do Termo de Compromisso Ambiental só poder ser assinado por engenheiros agrônomos e engenheiros florestais evidencia a importância dessa área.

O modo como a vegetação e sua relação com a cidade são entendidas revela melhor diferenças conceituais na atuação de engenheiros agrônomos e arquitetos. Profissionais da área de engenharia agronômica demonstram perceber as árvores sob enfoque numérico. A estrutura da legislação de compensação ambiental evidencia isso. O grau de complexidade das fórmulas para compensação ambiental demonstra esforços bastante válidos no sentido de conferir um caráter mais objetivo de aplicação da lei. Mas a visão excessivamente pontual, sem articulação com o contexto urbano, também pode resultar em ações problemáticas, facilmente observáveis na cidade de São Paulo: áreas irrelevantes densamente arborizadas, como forma de cumprir obrigações numéricas estabelecidas pela legislação.

Além disso, o papel da vegetação nas cidades é encarado diversas vezes com certo "romantismo" e ingenuidade. Transparece a idéia de que a existência da vegetação, desde que atendendo a diversos pré-requisitos biológicos e ecológicos estabelecidos, é capaz de trazer qualidade de vida ao meio urbano pela sua simples existência. De fato, a presença de massas arbóreas traz diversos benefícios ambientais para seu entorno. Mas os tipos de interação que a vegetação estabelece com os espaços livres também desempenham papel importante. 


\section{Empreendedores e o Poder Público}

As relações estabelecidas entre o Poder Público e os empreendedores exercem grande influência no andamento das compensações ambientais. É comum empreendedores terem reputação ruim perante os profissionais do Poder Público. E vice versa.

Tem-se a idéia (muitas vezes errônea) de que o empreendedor deseja "levar vantagens" sobre os profissionais da prefeitura ${ }^{224}$. Esse apriorismo leva a desconfianças injustificadas, que atravancam o processo de aprovação de empreendimentos.

O maior interesse do empreendedor reside nos lucros, nos quais a rapidez no retorno dos seus investimentos desempenha um papel importante. O principal objetivo do empreendedor é resolver seus problemas do modo mais rápido possível.

É consenso entre vários profissionais consultados para este trabalho que o custo das compensações ambientais representa uma parcela muito pequena do valor total de um empreendimento. $\mathrm{Na}$ maioria das vezes o empreendedor está disposto a custear a compensação com prontidão, mas em troca exige dos órgãos públicos igual rapidez no atendimento de suas solicitações. Essa agilidade diversas vezes não é possível, em virtude, dentre outros motivos, da quantidade insuficiente de técnicos para analisar a grande quantidade de projetos em andamento. Além da sobrecarga de trabalho, o processo de compensação ambiental envolve trâmites jurídicos trabalhosos e diversas vezes demorados.

Pressionado pela necessidade de agilizar o processo de aprovação, o empreendedor pode utilizar diversos recursos, nem todos eles éticos. Um deles é a possibilidade de desconsiderar a vegetação existente em seu terreno. Essa artimanha é auxiliada pela obsolescência dos levantamentos de vegetação significativa no município ${ }^{225}$.

Silva Filho afirma serem comuns casos de levantamento de terrenos para aprovação junto à Secretaria Municipal da Habitação que simplesmente ignoram a vegetação existente, como forma de agilizar trâmites burocráticos. Esse processo só ressalta a importância de um mapeamento abrangente e atualizado da vegetação arbórea do município.
224. Tal ponto de vista foi endossado pelos depoimentos da Arq. Miranda Magnolli e do Eng. Agr. José Manoel Gobbi.

225. Como já foi citado neste trabalho, o levantamento mais atualizado até o ano de 2008 era o volume "Vegetação Significativa, de 1988. 
226. Entrevista realizada em 21.01.2007

227. FANTINI, Débora. "Marketing verde": valoriza apartamentos Incorporadoras se valem da obrigação legal de preservação para vender lançamentos. Folha de São Paulo. Caderno Imóveis. 01 abril 2007.
Mas o maior problema relativo às compensações ambientais encontra-se na base conceitual daqueles que projetam. A otimização do projeto em função do lucro, em boa parte dos casos, vai de encontro aos interesses ambientais. A massa arbórea existente em um terreno representa um condicionante ao desenho, pode restringir bastante a área disponível para implantação de um empreendimento e acaba por exigir maior tempo para concepção. Nesse sentido, a aprovação das compensações representa uma variável a mais a ser pensada em projeto, podendo prolongar prazos estabelecidos, o que representa perdas de lucro para o empreendedor.

Tal raciocínio leva a vegetação existente no terreno a ser uma variável desconsiderada no momento de projetar. A desconsideração dos aspectos ambientais é um dos elementos que mais dificulta os processos de aprovação. Existe uma cultura profissional muito focada nos elementos construtivos, que desconsidera o espaço livre no ato de projetar.

De fato, a cultura do projeto focado no elemento construtivo ainda é forte entre arquitetos e engenheiros civis. Mas por outro lado, deve-se considerar a valorização que os espaços livres sofreram na última década em função do seu papel como elemento de marketing. Esse papel pode influir no modo como os empreendedores pensam a respeito das compensações ambientais. Observando os diversos processos de compensação de empreendimentos residenciais de seu bairro, a Arquiteta Maria Cristina Antunes ${ }^{226}$ considera que os empreendedores priorizam as compensações ambientais no entorno de suas obras, porque podem se apropriar das mesmas como instrumento de marketing. A respeito desse assunto, o trecho a seguir é bastante ilustrativo:

A preservação das árvores, que pode parecer uma iniciativa voluntária de construtoras e incorporadoras, geralmente não passa de cumprimento de exigências da legislação ambiental e do Plano Diretor. As mesmas árvores que servem para o incorporador barganhar na compra do terreno - pelos custos de realocação da vegetação - tornam-se apelo de marketing ao vender as unidades, diz Marcelo Cocco, diretor da DPAA (Divisão Técnica de Proteção e Avaliação Ambiental) da Secretaria Municipal do Verde e do Meio Ambiente."Há empresas que chegam pedindo para cortar tudo, mas, quando o lançamento sai no jornal, o apelo é 'venha morar perto do bosque tal'. Parece que o mérito é delas, quando a DPAA fez seu trabalho de proteger o ambiente”, conta Cocco. ${ }^{227}$ 
Diante dos altos lucros obtidos no mercado imobiliário, o técnico do Poder Público entende o empreendedor como fonte de recursos para custeio de ações necessárias à cidade. De fato, um dos conceitos principais implícitos na compensação ambiental arbórea é a captação de parte da mais-valia obtida pelo empreendedor às custas da desvalorização do patrimônio ambiental do município. Proporcionalmente, a contribuição dos gastos de compensação ambiental em relação ao valor global de um empreendimento imobiliário é irrisória, embora os representantes do mercado imobiliário busquem provar o contrário.

A esse respeito, vale citar uma correspondência muito interessante enviada Stela Goldenstein, Secretaria Municipal do Ambiente no ano de 2001. O documento referese a uma resposta dada pela secretária a questionamentos de representantes do mercado imobiliário sobre o alto custo que as compensações ambientais passariam a representar em função dos critérios adotados pela Portaria SVMA 122/2001 (que estava em processo de elaboração naquela época):

[...] a principal dúvida (ou discordância) ainda restante refere-se a quantidade de exemplares arbóreos a serem oferecidos em compensação quando da autorização para corte de árvores. Consta desta correspondência a notícia de que em certos casos 'o custo da compensação seria maior que o do terreno'. Devo dizer que esta possibilidade justamente comprova o raciocínio que embasa a Portaria. Cabe discutir como é composto o 'preço do terreno'. A presença de árvore no terreno hoje diminui seu preço de mercado. Mas aumenta seu valor para a sociedade. Isso porque o mercado está atento ao seu potencial construtivo, mas para a sociedade outros itens também tem significado, valor e custo, como a presença de árvores, por ex. Na verdade, o preço do terreno é o preço do terreno com seu potencial construtivo, mais o preço das árvores, ou a sua compensação. O custo do terreno para a incorporação pressupõe o custo necessário para a compensação. Se o terreno tiver muitas árvores, o preço pago ao proprietário deve contemplar o preço a ser pago pelo significado ambiental das árvores. Com regras claras o mercado ajusta-se rapidamente: o preço da adequação ambiental passa a fazer parte da equação financeira do empreendimento. Burlar as regras ambientais pode ter benefício financeiro a curto prazo, como não pagar FGTS, IR, encargos trabalhistas, etc. Mas com o avanço da tecnologia, ficar ao arrepio da legislação tem um custo também. $\mathrm{O}$ mais barato acaba sendo ficar correto legalmente, porque estas regras são exeqüíveis. ${ }^{228}$
228. Correspondência enviada pela então Secretaria Municipal do Meio Ambiente, Stela Goldenstein, a representantes do setor imobiliário em 11 de outubro de 2001. 
Por esse motivo, técnicos como o Eng. Agr. Ricardo Borgianni, afirmam que o "Poder Público deve buscar extrair o máximo do empreendedor" 229 . Mas não basta apenas extrair esses recursos, deve-se saber, de antemão, onde aplicá-los. E como já foi mostrado, este aspecto ainda é bastante deficitário na atuação do Poder Público.

Borgianni considera que parte da relutância dos empreendedores em ceder aos interesses públicos da compensação ambiental ocorre devido à não compreensão da importância do processo. O processo compensatório ainda é visto pelo empreendedor paulistano como um mal necessário, um sinônimo de entrave burocrático. O próprio Poder Público teria o dever de esclarecer melhor o funcionamento da legislação. Mas tanto o texto da legislação de compensação quanto a forma de atuação de alguns técnicos do Poder Público não possui a devida clareza. Serão necessários investimentos em trabalhos pedagógicos visando esclarecer a importância das compensações ambientais. No entanto, tal atitude corresponde apenas a uma parte da solução. A maior desconfiança do empreendedor recai sobre o tempo de espera para aprovação do seu processo.

\section{Interlocutores}

A relação entre Poder Público e empreendedores é mediada pelos responsáveis pelo Projeto de Compensação Ambiental - em geral arquitetos e engenheiros agrônomos. Essa atuação está sujeita a grandes desgastes, pois, como afirma Gobbi "o profissional responsável pela compensação funciona como uma espécie de esponja, que recebe impacto dos dois lados”. Os dois lados aos quais Gobbi se refere são os empreendedores e o Poder Público.

Ao funcionar como representante dos interesses do empreendedor, diversas vezes o interlocutor é mal visto pelo Poder Público, que o enxerga como instrumento do mercado imobiliário.

Ao mesmo tempo, o interlocutor tem de adaptar-se às diferentes necessidades temporais do contratante e dos órgãos ambientais. As exigências de rapidez do mercado imobiliário opõem-se ao ritmo geralmente mais lento de aprovação dos processos pelo Poder Público. 
Além desses fatos, o modo de trabalho do DEPAVE traz outro conflito na relação com os profissionais interlocutores. Como já foi visto, até o início dos anos 1990 esse departamento era responsável pela maioria dos projetos públicos de paisagismo realizados pela municipalidade. A cristalização do hábito de realizar projetos ocasiona resistência em delegar essa incumbência à iniciativa privada. A relutância em repassar atividades projetuais traz prejuízos ao próprio funcionamento do DEPAVE. Kawai afirma que a concentração de técnicos na área de projeto causa escassez de funcionários em outros setores da repartição, tais como fiscalização. 
230. Parques do Cordeiro, Jacintho Alberto, Vila Prudente, Pinheirinho D'Água, Parque Linear do Sapé e de Parelheiros. Praças Nandina Haddad Ambuda e Anna dos Santos Figueiredo.

231. Fonte: SVMA, 2008

\section{... E o que já foi realizado}

\section{Novos espaços livres}

Os dez anos de aplicação oficial das compensações ambientais na cidade de São Paulo (1998 a 2008) resultaram em ações concretas que, em maior ou menor grau, contribuíram para melhorias no seu sistema de espaços livres públicos.

O mecanismo auxiliou a captar recursos para um processo de viabilização de espaços livres que não ocorria na cidade desde a década de 1980. As compensações ambientais viabilizaram, em sete anos (de 2001 a 2008), a construção de seis parques e duas praças abertos ao público total ou parcialmente ${ }^{230}$, além de cerca de 1000 casos que contribuíram de modos diversos para o enriquecimento da arborização urbana ${ }^{231}$.

Excetuando o Parque da Vila Prudente, a responsabilidade pelo projeto de todos esses novos parques e praças foi entregue à iniciativa privada. Tal fato estabelece uma nova dinâmica no processo de criação de espaços livres públicos municipais, caracterizada pela maior influência da iniciativa privada. Se por um lado esse processo acentuou as dificuldades de produção devido aos conflitos mútuos para aceitação de diferentes modos de pensar do Poder Público e privado; por outro criou a possibilidade de aumento do padrão de qualidade dos projetos e alívio da sobrecarga da municipalidade.

A quantidade de parques custeados por compensações ainda é irrisória perto das carências da cidade. Mas representa um avanço se comparada à estagnação existente em períodos anteriores.

\section{Melhoras na distribuição}

As compensações ambientais também contribuíram para a melhor distribuição de espaços livres na cidade de São Paulo. Embora as compensações externas ao local do dano ambiental constituam exceção ao processo compensatório global, deve ser considerado seu potencial de atuação no sentido de amenizar a distribuição desigual de áreas de lazer no município. As compensações podem permitir que a área da cidade com melhor distribuição de espaços livres - o vetor sudoeste - desempenhe um papel importante no direcionamento de recursos para as outras regiões. 
Três motivos atuam de forma conjunta para explicar a relevância dessa região no contexto da geração de compensações.

O primeiro é o fato dessa região abrigar bairros com urbanização predominantemente planejadas, que possuem maior quantidade de arborização viária e de logradouros, tais como os Jardins, o Morumbi e o Brooklin. A existência de arborização urbana mais densa eleva o número de compensações ambientais necessárias, seja pela implantação de novos empreendimentos, seja pela reposição dos exemplares existentes.

O segundo é a capacidade de polarização da região para novos empreendimentos do setor imobiliário, notadamente aqueles de padrão de renda mais elevado, que possuem efetivas capacidades de custeio de compensações. Como foi visto anteriormente, os empreendimentos residenciais e comerciais são responsáveis pela maioria das compensações ambientais realizadas no município até o ano de 2008. A região também recebe grande quantidade de investimentos do poder público.

Um terceiro motivo relaciona-se à maior fiscalização à qual o vetor sudoeste está sujeito, que abriga população de maior poder aquisitivo e conseqüentemente possui maior visibilidade perante a opinião pública.

Somando-se esses elementos, temos a área da cidade onde não só as ações do Poder Público são mais efetivas, possibilitando a geração de mais compensações, como também os recursos para custeá-las são mais elevados.

\section{Aperfeiçoamento dos critérios}

A legislação de compensação ambiental na cidade de São Paulo foi constantemente aperfeiçoada ao longo dos seus dez anos de existência, apresentando melhoras significativas. Da simples reposição arbórea prevista pela lei 10.365/87, chegou-se a sofisticadas (dir-seia até mesmo complicadas) fórmulas matemáticas, que buscam atenuar danos ambientais por meio de variados critérios de valoração ecológica. 
Os aspectos técnicos relativos ao cálculo das compensações foram um dos que mais evoluíram. Isso talvez reflita o papel de destaque que a área da engenharia agronômica tem desempenhado na evolução do mecanismo. As Portarias a partir do ano de 2005 levam em consideração não só o porte da árvore retirada como também sua localização na cidade e espécie, introduzindo o conceito de valoração ecológica. E a quantia compensatória aumentou consideravelmente, apesar de alguns retrocessos como o caso do estabelecimento da proporção 1:1 para eucaliptos e pinus.

Os esforços no aperfeiçoamento técnico do texto da legislação não se refletiram necessariamente na melhora da estrutura de aplicação, o que pode comprometer todo o trabalho.

Ao mesmo tempo, a legislação aumentou gradativamente em importância, consolidandose como pré-requisito para aprovação de novos empreendimentos. Bem ou mal quista pelo setor imobiliário, a compensação tornou-se uma variável que eleva a importância da percepção dos aspectos ambientais no projeto do edifício. Para alguns profissionais do Poder Público, como Célia Seri Kawai e Carlos Alberto da Silva Filho, a relevância das compensações no projeto deveria ir além das modificações pontuais visando atender às exigências legais. Deveria condicionar o modo de projetar às variáveis ambientais. Mas não foi estabelecido pelo Poder Público, de forma detalhada, como devem ser os projetos arquitetônicos ambientalmente adequados.

Além disso, a variável que ainda mais pesa no momento de conceber novos empreendimentos é a econômica. Por esse motivo, Silva Filho considera que o custo das compensações deveria ser alto o suficiente para inibir projetos ambientalmente inadequados. Isso não tem ocorrido. Pelo contrário, medidas como a mudança da proporção compensatória de eucaliptos e pinus para 1:1 reduziram o custo de uma parte considerável das compensações no município. Isso evidencia que a percepção das variáveis ambientais ainda não é quesito suficiente para alterações substanciais na concepção dos projetos. Mas as alterações promovidas pelas compensações ambientais no município representam algum avanço. 


\section{Bibliografia citada}

ANDRADE, Rubens de. "Arborização: as práticas e os processos na formação da paisagem no Brasil.” In: Arborização: ensaios historiográficos. Rio de Janeiro: EBA/UFRJ, 2004.

BARTALINI, Vladimir. Parques públicos municipais de São Paulo. Tese de Doutorado. São Paulo: FAUUSP, 1999

BOUCINHAS, Caio. Projeto participativo na produção do espaço público. Tese de Doutorado. São Paulo: FAUUSP, 2005

CHAUÍ, Marilena. Natureza, Cultura, Patrimônio Ambiental. In: Lanna, A. L. D. (coord.) Meio ambiente: patrimônio cultural da USP. São Paulo: EDUSP: 2003.

DETZEL, V. A. Arborização urbana: importância e avaliação econômica. In: Congresso Brasileiro de Arborização Urbana, 1, 1992, Vitória. Anais I. Vitória: Prefeitura Municipal de Vitória, 1992. p.39-52.

FRÚGOLI Jr., Heitor. Centralidades em São Paulo. São Paulo. São Paulo: Edusp, 2000.

GELUDA,L.;YOUNG,C.E.F."Financiando o Éden: Potencial econômico e limitações da compensação ambiental prevista na Lei do Sistema Nacional de Unidades de Conservação da Natureza." In: IV Congresso Brasileiro de Unidades de Conservação, 2004, Curitiba. IV Congresso Brasileiro de Unidades de Conservação. Curitiba: Fundação O Boticário de Proteção à Natureza, 2004. v. 1. p. 641-651.

GONÇALVES, E. G; LORENZI, H. Morfologia Vegetal: Organografia e dicionário ilustrado de morfologia das plantas vasculares. São Paulo: Instituto Plantarum de Estudos da Flora, 2007.

GONCALVES, Wantuelfer. Padrões de assentamento de áreas verdes municipais - uma visão crítica. Tese de Doutorado. São Paulo: FAUUSP, 1994

HOUGH, Michael. Cities and Natural Process. London: Routledge, 1995. 
JÚNIOR, Roberto Vignola. A arborização de vias públicas e a paisagem urbana: caso da cidade de São Paulo. Dissertação de Mestrado. São Paulo: FAUUSP, 2005.

KAYDEN, Jerold S. Privately Owned Public Space : The New York City Experience. New York: John Wiley \& Sons, 2000.

LEITE, Maria Ângela Faggin Pereira. Destruição ou Desconstrução? Questões da paisagem e tendências de regionalização. São Paulo: Hucitec, 2006.

LIMA, Catharina Pinheiro Cordeiro dos Santos - A natureza na cidade, a natureza da cidade. Tese de Doutorado. São Paulo: FAUUSP, 1997

MACEDO, Silvio Soares. Quadro do paisagismo no Brasil. São Paulo: FAUUSP, 2000.

MAGNOLI, M. M. Espaço Livre - objeto de trabalho. In: Paisagem Ambiente: ensaios. n.21 São Paulo

MASCARO, L; MASCARÓ, J. Vegetação urbana. Porto Alegre: EDELBRA, 2002

MEDEIROS, M.A. A; NOGUEIRA,J. M.. Quanto vale aquilo que não tem valor? Valor de existência, economia e meio ambiente. In: Cadernos de Ciência E Tecnologia, Brasília, v.16, n.3 p. 78 set./dez. 1999

MENNEH, Márcia Unti Halluli - O sistema de espaços livres públicos da cidade de São Paulo. Tese de Doutorado. São Paulo: FAUUSP, 2002

PEREIRA, Raul Isidoro. O sentido da paisagem e a paisagem consentida. Tese de Doutorado. São Paulo: FAUUSP, 2007.

PIVETA, K. F. L.; SILVA FILHO, D. F.. Arborização Urbana. Boletim acadêmico. Jaboticabal: UNESP/FCAV/FUNEP, 2002

ROCHA, Marcelo Teotho. Aquecimento Global e o Mercado de Carbono - Uma aplicação do modelo CERT. Tese de Doutorado. Piracicaba: ESALQ, 2003. 
SAKATA, Francine Gramacho. O projeto paisagistico como instrumento de requalificação urbana. Dissertação de Mestrado. São Paulo: FAUUSP, 2004.

SANTOS, C. S.; SILVA, J. L. C. Os impactos do plantio de eucalipto e da produção de celulose em comunidades tradicionais no extremo sul baiano. In: II Encontro da Associação Nacional de Pós-Graduação e Pesquisa em Ambiente e Sociedade. Indaiatuba: ANPPAS, 2004

SÃO PAULO (Cidade), Secretaria Municipal do Verde e Meio Ambiente. Atlas Ambiental Municipal do Município de São Paulo. São Paulo: SVMA, 2002.

São Paulo (cidade). Secretaria Municipal do Verde e do Meio Ambiente. Diagnóstico Cartográfico Ambiental do Município de São Paulo. São Paulo: SVMA, 1992

SÃO PAULO (Cidade). Secretaria do Verde e do Meio Ambiente. IPT. GEO cidade de São Paulo: panorama do meio ambiente urbano. Brasília: PNUMA, 2004.

SÃO PAULO (Estado) Secretaria do Meio Ambiente / Secretaria Municipal de Planejamento - Vegetação Significativa no Município de São Paulo. São Paulo, 1988

SEROA DA MOTTA, R. Manual para valoração econômica de recursos ambientais. Brasília: Ministério do Meio Ambiente, 1998

SILVA FILHO, Carlos Alberto da. Proteção e fomento da vegetação no Município de São Paulo: possibilidades, alcance e conflitos. Tese de doutorado. São Paulo: FAUUSP, 2005

SILVA FILHO, Demóstenes Ferreira da. Efeito de borda no inventário dos maciços de eucalipto do Parque Ibirapuera por meio do uso de sensoriamento remoto e geoprocessamento. Revista da Sociedade Brasileira de Arborização Urbana. No 1 vol 2. Piracicaba, 2007.

SPIRN, Anne Whiston. O jardim de granito: a natureza no desenho da cidade. São Paulo: EDUSP, 1995

STESCHENKO, Wolfgang Sergio. Contribuição ao estudo e ao processo de produção da praça pública paulistana - o Departamento de Parques de Parques e Areas Verdes de São Paulo de 1967 a 1979. Dissertação de Mestrado. São Paulo: FAUUSP, 2001. 


\section{Bibliografia consultada}

BARCELOS, Vicente Quintella. Os parques como espaços livres públicos de lazer: o caso de Brasilia. Tese de Doutorado. São Paulo, FAUUSP, 1999

CAVALHEIRO, Felisberto; NUCCI, J.C. "Espaços Livres e Qualidade de Vida Urbana”. Paisagem e Ambiente: Ensaios. n. 11, dez. 1998, p. 277-288.

COELHO, Leonardo Loyolla. Um panorama das compensações ambientais em São Paulo. In: Paisagem e Ambiente - ensaios. n.21 - 2006. p. 228-237

DETZEL, Valmir Augusto. “Avaliação Monetária de Árvores Urbanas” In: Encontro Nacional Sobre Arborização Urbana, III. Curitiba, FUPEF, 1990. p.140-152

MAGNOLI, Miranda Martinelli. Espaços livres e urbanização: uma introdução a aspectos da paisagem metropolitana. Tese de livre-docência. São Paulo, FAUUSP, 1982.

MEYER, Regina Maria Prosperi. São Paulo Metrópole. São Paulo: EDUSP, 2004.

RAMALHO, Daniela. Rio Tamanduateí - nascente à foz: percepções da paisagem e processos. Dissertação de Mestrado. São Paulo: FAUUSP, 2005.

ROLNIK, Raquel. A cidade e a lei: legislação, política urbana e territórios na cidade de São Paulo. São Paulo, Studio Nobel: FAPESP, 2003.

SILVA, José Afonso da. Apostila da disciplina "Direito Ambiental" Faculdade de Direito da Universidade de São Paulo. 2º semestre 1990

TRINDADE, Jeanne. "O século XX e a consolidação do elemento arbóreo no desenho urbano das cidades brasileiras.” In Arborização: ensaios historiográficos. Rio de Janeiro: EBA/UFRJ, 2004. 


\section{Entrevistas}

Arq. Raul Pereira - 28.03.2005

Arq. Caio Boucinhas - 27.10.2005 e 10.01.2007

Arq. Célia Seri Kawai - 15.03.2007

Arq. Miranda Martinelli Magnoli - 17.11.2005 e 04.03.2007

Eng. Agr. Carlos Alberto da Silva Filho - 14.02.2007

Eng. Agr. Marcelo Cocco Urtado - 19.01.2006

Eng. Agr. e Arq. José Manoel Gobbi - 06.04.2006

Geógr. Ana Beatriz Goshuen - 21.01.2007

Eng. Agr. Jorge Sakai - 09.01.2007

\section{Jornais}

::::::. Em SP, licenças viabilizaram 47 parques. Caderno imóveis, Folha de São Paulo. 09 de novembro de 2003.

::::::: Na zona sul, área de lazer não saiu do papel. Caderno cotidiano, Folha de São Paulo. 25 de janeiro de 2004.

::::::. Obra de corredor de onibus leva a corte de mais 65. Caderno cotidiano, Folha de São Paulo. 17 de março de 2006

::::::. Pacote de atrativos inclui praça e canteiro. Folha de São Paulo. Caderno Imóveis. 01 Abril 2007.

::::::. Prefeitura promete cinco novos parques. O Estado de São Paulo. 15 de janeiro de 2006

BALAZINA, Afra. Cidade ainda tem 7 parques inacabados. Caderno cotidiano, Folha de São Paulo. 19 de novembro de 2005. 
DIMENSTEIN, Gilberto. O assassinato das cerejeiras. Caderno cotidiano, Folha de São Paulo. 28 de janeiro de 2004.

FANTINI, Débora. "Marketing verde" valoriza apartamentos: Incorporadoras se valem da obrigação legal de preservação para vender lançamentos. Folha de São Paulo. Caderno Imóveis. 01 abril 2007.

GERAQUE, Eduardo. Neutralização de CO2 esbarra em método. Folha de São Paulo. Caderno Ciência. 29 dezembro 2007

GONZALES, Daniel. Parques precisam de parceiros. In Suplemento Estadão Oeste Caderno Dia-a-dia, O Estado de São Paulo. 18 de fevereiro de 2005

KÜCHLER, A. Caos ecológico leva pessoas a neutralizarem culpa e carbono. Folha de São Paulo. Caderno Cotidiano. 26 agosto 2007

PELLIM, Roberto. Atrasada, Marta entrega primeiro parque. Caderno cotidiano, Folha de São Paulo. 08 de setembro de 2002.

PRIMI, Lillian. Prefeitura reduz indice para replantio de árvores. Caderno Construção, O Estado de São Paulo. 12 de março de 2006.

RIBEIRO, Mônica. Para combater enchentes, cidade vai ganhar 11 parques lineares. Diário Oficial da Cidade de São Paulo. 15 de fevereiro de 2007.

SAMMOGINI, Alexandre. Construtora só corta árvore se criar parque. Caderno imóveis, Folha de São Paulo. 18 de maio de 2003.

VIVEIROS, Mariana. Cidade deve ganhar 3 novos parques. Caderno cotidiano, Folha de São Paulo. 06 de janeiro de 2002.

VIVEIROS, Mariana. Meta é abrir quatro parques em 2004. Caderno cotidiano, Folha de São Paulo. 25 de janeiro de 2004. 


\section{Legislação}

\section{Legislação Federal}

Leis

Lei Federal no 9.985 de 18 de julho de 2000. Regulamenta o art. 225, § 1o, incisos I, II, III e VII da Constituição Federal, institui o Sistema Nacional de Unidades de Conservação da Natureza e dá outras providências.

Lei Federal no 6.938 de 31 de agosto de 1981. Dispõe sobre a Política Nacional do Meio Ambiente, seus fins e mecanismos de formulação e aplicação, e dá outras providências

Lei Federal no 4.771 de 15 de setembro de 1965. Institui o novo Código Florestal

\section{Medidas provisórias}

Medida Provisória 2163-41 de 23 de agosto de 2001. Acrescenta dispositivo à Lei no 9.605, de 12 de fevereiro de 1998, que dispõe sobre as sanções penais e administrativas derivadas de condutas e atividades lesivas ao meio ambiente.

\section{Resoluções}

Resolução CONAMA 010/1987 de 03 de dezembro de 1987. Detalha procedimentos para reparação de danos ambientais.

Resolução CONAMA 001 de 23 de janeiro de 1986. Estabelece as definições, as responsabilidades, os critérios básicos e as diretrizes gerais para o uso e implementação da Avaliação de Impacto Ambiental

\section{Legislação Estadual}

\section{São Paulo}

\section{Decretos}

Decreto Estadual no 39.743 de 23 de dezembro de 1994. Dá nova redação ao artigo 18 do decreto $\mathrm{n}^{\circ} 30.443$, de 20 de setembro de 1989 
Decreto Estadual no 30.433, de 20 de setembro de 1989. Considera patrimônio ambiental e declara imunes de corte exemplares arbóreos situados no município de São Paulo e dá outras providências.

\section{Legislação Municipal}

\section{Porto Alegre}

Decreto Municipal no 15.418 de 20 de dezembro de 2006. Dispõe sobre os procedimentos para supressão, transplante ou podas de espécimes vegetais e dá outras providências

\section{Rio de Janeiro}

Lei orgânica do município do Rio de Janeiro.

Resolução SMAC 345 de 19 de maio de 2004. Dispõe sobre os procedimentos a serem adotados nas solicitações de autorização para remoção de vegetação e na implantação de medidas compensatórias no município do Rio de Janeiro.

\section{São Paulo}

\section{Leis}

Lei Municipal no 13.885, de 25 de agosto de 2004. Estabelece normas complementares ao Plano Diretor Estratégico, institui os Planos Regionais Estratégicos das Subprefeituras, dispõe sobre o parcelamento, disciplina e ordena o Uso e Ocupação do Solo do Município de São Paulo.

Lei Municipal no 13.430 de 13 de setembro de 2002. Plano Diretor Estratégico do Município de São Paulo.

Lei Municipal no 11.605 de 12 de julho de 1994. Dispõe sobre a criação da subcategoria de uso residencial R3-03, conjunto residencial - vila, e dá outras providências. 
Lei Municipal no 11.426/1993. Cria a Secretaria Municipal do Verde e do Meio Ambiente - SVMA, cria o Conselho Municipal do Meio Ambiente e Desenvolvimento Sustentável e dá outras providências.

Lei Municipal no 10.365 de 22 de setembro de 1987. Disciplina o corte e a poda de vegetação de porte arbóreo existente no Município de São Paulo e dá outras providências.

Lei Municipal no 9.413, de 30 de dezembro de 1981. Dispõe sobre o parcelamento do solo no Município de São Paulo, e dá outras providências.

Lei Municipal no 8.491 de 14 de dezembro de 1976. Cria o Departamento de Parques e Áreas Verdes do município de São Paulo (DEPAVE) e dá outras providências.

Lei Municipal no 7805 de 01 de novembro de 1972. Dispõe sobre o parcelamento, uso e ocupação do solo do Município, e dá outras providências.

Lei Municipal no 7.108, de 10 de janeiro de 1968. Cria o Departamento de Parques e Jardins do município de São Paulo

\section{Decretos}

Decreto Municipal no 47.937 de 30 de novembro de 2006. Dá nova redação ao “caput” do artigo $4^{\circ}$ do Decreto $n^{\circ} 47.145$, de 29 de março de 2006, que regulamenta o Termo de Compromisso Ambiental - TCA, instituído pelo artigo 251 e seguintes da Lei ${ }^{\circ}$ 13.430, de 13 de setembro de 2002 (Plano Diretor Estratégico).

Decreto Municipal no 47.145 de 29 de março de 2006. Regulamenta o Termo de Compromisso Ambiental - TCA, instituído pelo artigo 251 e seguintes da Lei no 13.430, de 13 de setembro de 2002 (Plano Diretor Estratégico).

Decreto Municipal no 26.535/1988. Regulamenta a Lei no 10.365, de 22 de setembro de 1987, que disciplina o corte e a poda de vegetação de porte arbóreo existente no município de São Paulo e dá outras providências. 


\section{Portarias}

Portaria 006 /SVMA.G/2007. Altera o item 3 da Portaria 5/SVMA./2006 publicado no D.O.C. de 19/01/2006

Portaria 005/SVMA.G de 19 de janeiro de 2006. Disciplina os critérios e procedimentos de compensação ambiental pela remoção por corte, transplante, ou qualquer outra intervenção, de caráter excepcional, de vegetação de porte arbóreo no município de São Paulo.

Portaria 042/SVMA.G/2005. Institui e organiza a Câmara de Compensação Ambiental (CCA), na Assessoria Técnica da Secretaria Municipal do Verde e do Meio Ambiente.

Portaria 009/SVMA.G de $1^{\circ}$ de fevereiro de 2005. Disciplina os critérios e procedimentos de compensação ambiental pela remoção por corte, transplante, ou qualquer outra intervenção, de caráter excepcional, de vegetação de porte arbóreo no município de São Paulo.

Portaria 026/2004 SVMA.G, de 10 de março de 2004. Disciplina os critérios e procedimentos de compensação ambiental pela remoção por corte, transplante, ou qualquer outra intervenção, de caráter excepcional, de vegetação de porte arbóreo no município de São Paulo.

Portaria 136/SVMA.G de 20 de dezembro de 2003. Disciplina os critérios e procedimentos de compensação ambiental pela remoção por corte, transplante, ou qualquer outra intervenção, de caráter excepcional, de vegetação de porte arbóreo no município de São Paulo.

Portaria Intersecretarial 05/SMMA-SIS de 27 de julho de 2002. Estabelece orientação técnica para projeto e implantação de arborização em vias e áreas livres publicas.

Portaria Intersecretarial 04/SMMA-SIS/2002. Disciplina a tramitação e a instrução dos expedientes relativos à remoção de vegetação de porte arbóreo, considerada patrimônio ambiental e imune ao corte, nos termos do Decreto Estadual n 30.443, de 20 de setembro de 1989. Atribui ao engenheiro agrônomo, responsável técnico pela Unidade de Parques e Jardins - UPJ de cada Administração Regional, vistoriar e emitir parecer conclusivo em expedientes relativos a pedidos de remoção de exemplares arbóreos. 
Portaria 122/SMMA.G, de 11 de outubro de 2001. Disciplina os critérios e procedimentos de compensação ambiental pela remoção por corte, transplante, ou qualquer outra intervenção, de caráter excepcional, de vegetação de porte arbóreo no município de São Paulo.

Portaria 121/SMMA-G de 11 de outubro de 2002. Institui e organiza o Núcleo para a Legislação de Proteção e Fomento da Vegetação - NLPFV no Departamento de Parques e Âreas Verdes - DEPAVE.

Portaria 088/SMMA.G de 04 de setembro de 1999. Estabelece critérios para a compensação ambiental pela remoção, em caráter excepcional, de exemplares arbóreos protegidos pelo Decreto Estadual 30.443, de 23 de dezembro de 1989

\section{Memorandos}

Memorando no 41/DEPAVE-G/1998. Propõe critérios para compensação ambiental arbórea no município de São Paulo

\section{Revistas}

BORSATO, Cíntia. A neutralização da culpa. Revista Veja. 21 fevereiro 2007

CENTOFANTI, M. Temporada de quedas: Chuva forte derruba 209 árvores em um dia. Cupins e descuido agravam o problema. Revista Veja São Paulo. 23.11.2006

LIMA, E. ; PASSOS, I. Bairro de alto padrão. Conhecido por abrigar prédios de luxo e símbolo de status, o Jardim Anália Franco ganha um centro de compras com grifes famosas. Revista Veja São Paulo. 24 novembro 1999.

MONTEIRO, Lúcia. $R \$ 350,00$. E lá se vai mais uma árvore. Revista Veja São Paulo. 21 abril 2004.

Paisagem e Ambiente - ensaios - n.21 - 2006

SOARES, Sandra. O Quebra Galho: Há uma árvore no meio do caminho? Chame André Ostermayer. Revista Veja São Paulo. 19 Abril 2006 


\section{Sites}

DEPRN - Departamento Estadual de Proteção de Recursos Naturais www.ambiente.sp.gov.br/deprn/deprn.htm

Instituto Brasileiro do Meio Ambiente e dos Recursos Naturais Renováveis www.ibama.gov.br

IBGE - Instituto Brasileiro de Geografia e Estatística - Cidades @ www.ibge.gov.br/cidadesat/default.php

Projeto Plantas On Line - legislação do município de São Paulo http://plantasonline.prefeitura.sp.gov.br/legislacao/legislacao.php

SABESP - Projeto Córrego Limpo

www.corregolimpo.com.br

SABESP - Projeto Tietê

www2.sabesp.com.br/projetotiete

Secretaria Municipal do Meio Ambiente da cidade de Porto Alegre www.portoalegre.rs.gov.br/smam

Secretaria Municipal de Meio Ambiente da cidade do Rio de Janeiro www.rio.rj.gov.br/smac

Secretaria do Verde e Meio Ambiente do Município de São Paulo www2.prefeitura.sp.gov.br/secretarias/meio_ambiente

Sociedade Amigos do Jardim Petrópolis e dos Estados www.sajape.org.br

The Carbon Neutral Company www.carbonneutral.com 


\section{Apêndice}

\section{Funcionamento das Compensações Ambientais no Município de São Paulo}

Como se observou anteriormente, a legislação compensatória de São Paulo funcionou, com poucas exceções, de modo cumulativo ao longo de seus onze anos de aplicação, sendo os aperfeiçoamentos incorporados a cada novo texto apresentado. Desse modo, a descrição do funcionamento do processo compensatório conforme o Decreto Municipal 47.145/2006 representa uma síntese do que foi realizado até o ano de 2008.

1. Constatação da existência de árvores no terreno pelo proprietário (denominado pela SVMA como "interessado"). Essa situação obriga-o a apresentar o projeto do empreendimento tanto à Secretaria de Habitação (SEHAB), quanto à SVMA. Na via apresentada à SVMA, além do projeto construtivo, o interessado insere a locação e os detalhes das árvores existentes no terreno.

2. Depois de analisar o projeto, a SVMA solicita ao interessado um Projeto de Compensação Ambiental (PCA). Esse projeto - que deve ser realizado obrigatoriamente por um engenheiro agrônomo ou florestal - contempla as árvores a serem retiradas e a sugestão dos destinos para elas.

3. Análise da SVMA e determinação do que deverá ser feito pelo interessado em compensação à retirada das árvores solicitadas (medida compensatória). Como foi visto anteriormente, existem três possibilidades (denominadas pela SVMA como medidas compensatórias):

- Plantio interno ao terreno - constitui a prioridade para o Poder Público.

- Plantio externo ao terreno - casos nos quais as mudas não cabem no terreno.

- Conversões da medida compensatória - consiste na realização de formas alternativas de compensação. Ocorrem em situações nas quais o plantio de mudas no entorno do empreendimento não é possível ou em casos especiais determinados pela SVMA. Dentre as diversas possibilidades de conversão estabelecidas pela SVMA, destacam- 
se a realização de obras e serviços em áreas livres públicas, a aquisição de terrenos para implantação de espaços livres públicos, o custeio de projetos de educação ambiental ou o custeio de projetos e levantamentos para implantação de espaços livres públicos.

4. Quando o PCA é aprovado, a SVMA emite um Laudo de Avaliação Ambiental. Esse documento confirma para a SEHAB o encaminhamento do processo na SVMA. Ele é apresentado juntamente com o projeto para o empreendimento e o PCA. Caso a SEHAB aprove a documentação apresentada, emite-se um Alvará de Aprovação da obra.

5. A apresentação desse alvará à SVMA, juntamente com o restante da documentação já apresentada anteriormente, autoriza a emissão de um Termo de Compromisso Ambiental (TCA).

Tecnicamente, o TCA estabelece um vínculo entre Poder Público e o empreendedor, colocando o cumprimento do escopo do Projeto de Compensação Ambiental como condição para execução da obra. Caso este não seja cumprido, o TCA permite que o Poder Público faça a cobrança, em qualquer momento, do cumprimento da compensação estabelecida.

6. Apresentação do TCA junto com o Alvará de Aprovação à SEHAB, que emite um Alvará de Execução. Só a partir desse momento - com a posse do TCA e do Alvará de Execução - o interessado está completamente autorizado a executar sua obra.

O vínculo entre o TCA e a autorização para execução da obra é o elemento que confere poder a esse documento. Tal vínculo explica a importância dada pelo empreendedor ao TCA. Sem o cumprimento adequado das compensações ambientais pendentes, a obra não sai do papel.

7. Fechamento final dos processos junto à SEHAB e SVMA. O modo de encerramento depende do tipo de compensação ambiental determinada para a obra. Existem três tipos de certificados ambientais emitidos pela SVMA que atestam a realização de compensações ambientais em função das obrigações cumpridas: 
- Termo de Recebimento Parcial - emitido para empreendimentos cujas obras não foram concluídas, mas nos quais as compensações por plantio externo e as conversões de medida compensatória já foram realizadas. $O$ certificado não dá direito ao Certificado de Conclusão da obra (Habite-se), que fica vinculado à realização do plantio compensatório interno ao terreno do empreendimento. Desse modo, busca-se garantir que as obras construtivas não causem danos às mudas plantadas internamente ao terreno do empreendimento.

- Termo de Recebimento Provisório - emitido quando todas as compensações solicitadas ao empreendedor foram realizadas. O certificado dá direito ao Habite-se. O término do processo junto à SVMA fica vinculado a uma vistoria após o prazo de manutenção previsto no TCA, que varia de 12 a 24 meses.

- Termo de Recebimento Definitivo - emitido quando a vistoria final de técnicos da SVMA confirme que todas as compensações previstas (internas, externas e conversões) foram feitas e a manutenção das mudas compensatórias foi realizada durante o prazo previsto no TCA.

Fluxograma do processo de aprovação das compensaç̃̃es ambientais arbóreas no município de São Paulo em 2008

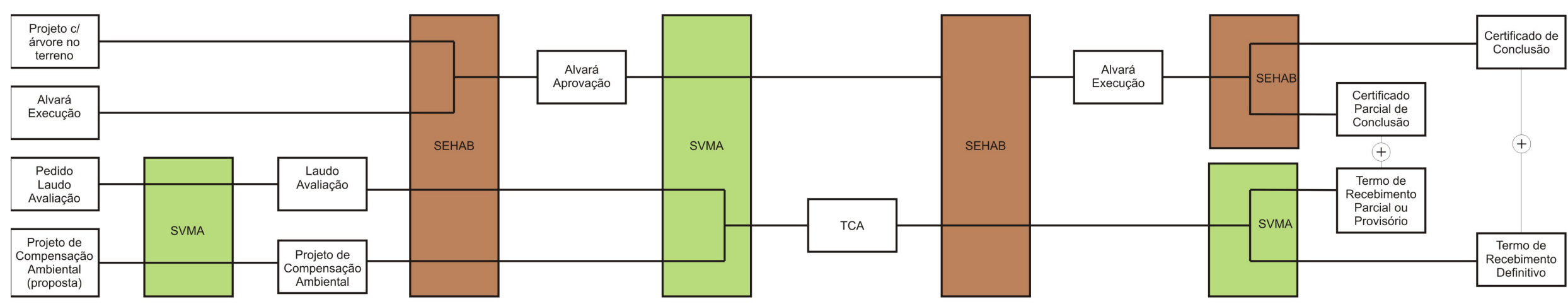




\section{Anexo}

\section{Memorando DEPAVE 41/1998}

Com exceção do Memorando 41, todas a demais portarias referentes às compensações ambientais na cidade de São Paulo até o ano de 2008 encontram-se disponibilizadas via internet, em websites da prefeitura.

\section{PREFEITURA DO MUNICIPIO DE SÃO PAULO \\ SECRETARIA DO VERDE E DO MEIO AMBIENTE \\ DEPARTAMENTO DE PARQUES E ÁREAS VERDES}

São Paulo, 29 de janeiro de 1998

MEMO No 41/DEPAVE-G/98

SVMA/G-AJ(SISPRO 6027-10.010)

Sra Assessora Chefe

No intuito de editar portaria que determine as medidas compensatórias ao corte e/ou transplante de exemplares arbóreos a serem adotadas por DEPAVE, sugerimos como critérios a serem seguidos para:

1. Remoção de exemplar de porte arbóreo situado em logradouro público/próprio municipal.

a. O exemplar a ser cortado ou transplantado, em função de seu estado fitossanitário, risco iminente de queda ou danos ao imóvel, deverá ser reposto na proporção 1:1 pela Administração Regional competente.

b. O exemplar a ser cortado ou transplantado se a remoção ocorrer por interesse do próprio munícipe (edificação ou entrada de garagem), deverá ser reposto em função do seu porte (de acordo com o seu diâmetro a altura do peito-DAP) e a forma de remoção (corte ou transplante), conforme Tabela 1. 
TABELA 1. Compensações para exemplares arbóreos a serem removidos, situados em logradouro público/próprio municipal.

\begin{tabular}{lcc}
\hline $\begin{array}{l}\text { D.A.P } \\
(\mathrm{cm})\end{array}$ & $\begin{array}{l}\text { Número de mudas a serem entregues à Municipalidade por } \\
\text { exemplar de porte arbóreo a ser removido }\end{array}$ \\
\hline \multicolumn{3}{c}{ remoção } \\
\hline $0-10$ & 3 & transplante \\
$11-30$ & 6 & 1 \\
Maior ou igual a 31 & 12 & 3 \\
\hline
\end{tabular}

No caso descrito no item 1.b, deverá ser lavrado um Termo de Compromisso Ambiental (T.C.A.) entre o interessado e a SVMA, para que as medidas compensatórias propostas por DEPAVE sejam efetivamente adotadas.

2-Remoção de exemplar arbóreo situado em propriedade particular, com lavratura de T.C.A.

a. quando a compensação for realizada dentro do próprio terreno, o plantio das mudas será realizado pelo interessado, conforme Tabela 2. 
TABELA 2. Compensações, dentro do próprio terreno, para exemplares arbóreos a serem removidos, situados em propriedade particular

\begin{tabular}{|c|c|c|c|}
\hline \multirow{4}{*}{ D.A.P. } & \multicolumn{2}{|r|}{ Justificativa } & \\
\hline & \multicolumn{2}{|r|}{ Interesse particular } & \multirow{2}{*}{$\begin{array}{r}\text { Est. Fitossanitário/ } \\
\text { Perigo iminente de queda/ } \\
\text { danos ao imóvel }\end{array}$} \\
\hline & corte & transplante & \\
\hline & \multicolumn{3}{|c|}{ Número de mudas a serem plantas por exemplar de porte arbóreo a ser removido } \\
\hline $0-10$ & $3: 1$ & $1: 1$ & $1: 1$ \\
\hline $11-30$ & $6: 1$ & $2: 1$ & $2: 1$ \\
\hline $\begin{array}{l}\text { Maior ou } \\
\text { Igual a } 31\end{array}$ & $12: 1$ & $3: 1$ & $3: 1$ \\
\hline
\end{tabular}

b. Quando a compensação for feita em áreas do entorno do imóvel, as reposições seguirão conforme Tabela 3: 
TABELA 3. Compensações, em áreas do entorno, para exemplares arbóreos a srem removidos situados em propriedade particular

\begin{tabular}{|c|c|c|c|}
\hline \multirow{4}{*}{ D.A.P. } & \multicolumn{3}{|c|}{ Justificativa } \\
\hline & \multicolumn{2}{|c|}{ Interesse particular } & $\begin{array}{r}\text { Est. Fitossanitário/ } \\
\text { Perigo iminente de queda/ } \\
\text { danos ao imóvel }\end{array}$ \\
\hline & Corte & transplante & $\begin{array}{l}\text { corte/ } \\
\text { transplante }\end{array}$ \\
\hline & \multicolumn{3}{|c|}{$\begin{array}{l}\text { Número de mudas a serem entregues à Municipalidade + protetores por } \\
\text { exemplar de porte arbóreo a ser removido }\end{array}$} \\
\hline $0-10$ & 6 mudas +3 protetores & 2 mudas +1 protetor & 1 \\
\hline $11-30$ & 12 mudas +6 protetores & 4 mudas +2 protetores & 2 \\
\hline $\begin{array}{l}\text { Maior ou } \\
\text { Igual a } 31\end{array}$ & 24 mudas +12 protetores & 6 mudas +3 protetores & 3 \\
\hline
\end{tabular}


Nos casos de remoção, por corte e/ou transplante de exemplares arbóreos considerados raros, por critérios estabelecidos pelo DEPAVE, as proporções deverão ser dobradas e serem coletadas, previamente, sementes ou outro material propagativo do exemplar a ser removido. Nestes casos, pelo menos, uma das mudas a ser plantada deverá ser da mesma espécie do exemplar arbóreo a ser removido, sendo dispensada a obrigatoriedade de porte mínimo de mudas.

Se os transplantes não tiverem sucesso, as compensações serão as mesmas previstas para o corte, em todas as situações mencionadas.

As mudas utilizadas para compensação deverão ter, no mínimo, altura de 2,5 a 3,0 m, sendo 1,8 m do colo à primeira bifurcação, e D.A.P. - diâmetro à altura do peito de $3 \mathrm{~cm}$.

A entrega das mudas referentes aos itens 1.b e 2.b deverá ser feita no DEPAVE2, Viveiro Manequinho Lopes - Parque do Ibirapuera, Portão 7-A, a/c Engenheiro Agrônomo Diretor da Divisão, no prazo máximo de 30 dias, após o corte e/ou transplante, juntamente com as notas fiscais de compra, com discriminação das mudas e uma via do T.C.A. firmado.

Atenciosamente

\section{IVAN DE FREITAS}

Diretor de DEPAVE

ASCB (cb.memog41.doc) 